\title{
NINA BERBEROVA'S LETTERS TO SERGEJ RITTENBERG
}

c/o Asplund

Hemmarö

Furusund

20 июня (1947?)

Дорогой Сергей Александрович,

только теперь начинаю оживать и чувствовать себя человеком - отоспалась и отъелась немного. Погода была все время холодная, но это было как то неважно, т.к. в доме топили печку и очень было уютно. Я работала, читала, и гуляла под дождиком.

Сегодня солнце. И видимо в одни сутки поспеет земляника и выйдут грибы - здесь это так полагается. Несколько раз выходили в море на моторной лодке. Ловили вечерами щук в тростниках. Это все развлечения.

А Вы? Что Вы думаете о берлинских делах ${ }^{19}$ Не будет ли и в самом деле война? Я здесь сижу без всякой информации: шведского радио не понимаю и едва разбираю газеты. Жду от Вас умных разъяснений: что мне думать?

Из Парижа какие-то все грустные письма... Я читаю замечательную книгу о тибетской мудрости. Там нет ни чувств, ни тревог, ни уныния - одна мудрость. Вот бы и нам!

Я сочинила стишок, Вам посвященный:

Мы по Мэлару поедем,

Или в сад гулять пойдем.

Там, где тигры и медведи,

Будем мы сидеть вдвоем.

Как рисунок старой «Нивы«:

Чайки. Зыбь. Закат вдали.

19 In the spring of 1947 the Soviet Union was accused of sabotaging the American program for the reconstruction of Germany. Secretary of State Dean Acheson declared in this connection that "Europe is hemorrhaging financially and next year we can expect a worldwide crisis" (Dagens Nyheter, 16 June 1947). 
Ax, какие перспективы!

Ах, какое Тиволи!!20

С почтением

Автор

20 Berberova was looking forward to a boat trip to Drottningholm outside Stockholm and to visiting the Skansen zoo and the Tivoli Gröna Lund amusement park. In Drottningholm Greta Gerell's friend Greta Asplund (1885-1974) - PE instructor, outdoor enthusiast and something of her mentor - had her winter residence high up in "Bergshyddan" overlooking Lake Mälaren. Much suggests that Berberova had been a guest here during her visit to Stockholm in 1946. 
16 июля 1947

Дорогой Сергей Александрович,

сегодня посылаю Вам посылку книг: Г. Иванов, ${ }^{21}$ А. Ладинский, ${ }^{22}$ Орион $^{23}$ и «Некрополь « Ходасевича ${ }^{24}$ /большая редкость/. Все это мне стоило 420 франков. Остается 80. Постараюсь на остаток найти Ахматову подержанную, т.к. в магазинах ее нет. Все это я послала заказным и надеюсь все дойдет в целости.

Здесь тяжко, жарко, и ощущение у меня такое, что праздник мой кончился. Вспоминаю пестрый вечер, проведенный с Вами в «Тиволи«, и милую прогулку в Тильс Галери. ${ }^{25}$ Да, это было все хорошо и безоблачно.

Газеты тоже Вам посылаю, для Вас и Нильсона. ${ }^{26}$ Кнутсону ${ }^{27}$ «Блока ${ }^{28}$ послала. Дочитали ли Вы его? Не разочаровывались ли? Здесь отзывы пока были только устные, но все хорошие, и я очень рада. Будут главу читать в радио, а также переводы, - бывает здесь такой «литературный час«.

Я жалею, что не сделала с Вас снимка. Почему? Где был мой аппарат, и почему я его не взяла с собой в тот день? Не понимаю. Все мои шведские снимки радуют меня очень, особенно шхерные, на лодке. От них здесь веет свежим воздухом и запахом сосен.

Едете ли Вы в отпуск? Что делаете? Я послала г-же Сырейщиковой письмо. ${ }^{29}$ Увижусь с ней на днях и передам ей Ваш пакет. Из Сток-

$21 \quad$ See note 86 to Berberova's letter of 3 April 1948.

22 Probably, Antonin Ladinskij's (1896-1961) collection of poems Pjat' čuvstv, Paris 1938. See Kursiv moj, 321-323.

23 Orion, "literaturnyj al'manach pod redakciej Jurija Odarčenko, Vladimira Smolenskogo, Anatolija Sajkeviča," Paris 1947. In connection with her newly published biography of Blok, Berberova contributed " 25 let smerti A. Bloka."

24 Vladislav Chodasevič, Nekropol'. Vospominanija, Brussels 1939.

25 The Thiel Gallery, art museum a short walk from the Tivoli Gröna Lund amusement park (see note 20 to Berberova's letter of 20 June (1947?)).

26 Nils Åke Nilsson (1917-1995), newly appointed head of the book collections at the Russian Institute, from 1967 professor of Slavic languages at Stockholm University. More than anyone else, he would later be responsible for introducing Russian literature in Sweden.

27 Knut Knutsson (1897-1989), city librarian, interim professor of Slavic languages at the Stockholm University. He and Kajsa Rootzén had translated Berberova’s Čajkovskij biography (see my introduction, 4).

28 Nina Berberova, Alexandre Blok et son temps, Paris 1947.

29 Rittenberg's Paris friend Syrejščikova, wife of former State Councillor Nikolaj Syrejščikov (Nicolas Syreistchikoff, 1864-1948). 
гольма мои друзья меня спрашивают: когда я думаю опять приехать? И я начинаю уже /совершенно безумно и нелепо/ думать о будущем годе. И мы опять пойдем в Тиволи и будем есть мороженое.

«Орион« Вам доставит удовольствие, это я знаю. В нем много чтения. Обратите внимание на статью Злобина: по моему, это шедевр. ${ }^{30}$

Возможно, что я останусь в Париже на лето, т.к. мне необходимо переехать, а это очень трудно сейчас. Я вообще предпринимаю «чистку« своей жизни, вооружаясь огромной шваброй.

Жму Вашу руку.

НБерберова

30 Vladimir Zlobin, "Kak oni umerli” (on Dmitrij Merežkovskij and Zinaida Gippius's final days). See also note 159 to Berberova's letter of 3 January 1950. 


\section{ЭПИГРАФ:}

Ах, Тиволи, - нет в мире лучше края!.. ${ }^{31}$

30 июля 1947

Дорогой Сергей Александрович,

получила Ваше милое и остроумное письмо. Ах, представьте себе, и я уже начинаю мечтать о будущем лете: слишком хорошо было мне в Швеции. А здесь - 40 градусов в тени...

Вы наверное уже знаете, что м-м Сырейщикова была у меня. ${ }^{32}$ Она сидела с час и мы поговорили о Вас. Она произвела на меня впечатление необъяснимо-грустное: вообразите женщину со следами былой красоты, с чудными волосами, но совершенно мертвым взглядом, как будто судьба ее била лет тридцать безостановочно. Я не понимаю, почему она такая? Муж - жив, дети живы и счастливо женаты, никаких жертв она не несла и горя не испытала, но видимо это из тех натур, которые и без горя и без жертв могут впасть в отчаяние. Все, что она говорила, было полно страшного пессимизма и она ни разу не улыбнулась... Пишу Вам это, прося ей ничего не говорить, конечно, иначе она может решить, что она мне не понравилась, а она мне очень понравилась, только поразила страшно, и когда она ушла, я не могла отделаться от тягостного впечатления какого то непонятного мне страдания, или, вернее, не страдания, а многолетней жизненной тяжести, которую эта женщина несет с собой. Может быть эта тяжесть даже не реальна, но для нее она прямо непосильна.

Шоколад я передала.

Ахматову до сих пор не послала Вам, милый друг, но пошлю, как только разыщу. ${ }^{33}$ Она нигде здесь не продается больше в магазинах. Сама я сегодня Вам длинно писать не могу: я совершенно погибаю от жары. Приехал из Америки мой друг, давний и мне очень дорогой - художник Добужинский. И я сегодня еду к нему на весь день за город - это спасет меня от жары в городе. Но ночью спать невозможно,

31 An allusion to Čackij's famous line in the final act of Griboedov's Gore ot uma: “Francija! Net v mire lučše kraja!” Berberova wants to express her enormous gratitude to what her stay in Stockholm and on Hemmarö gave her, so that an ironic parallel with Čackij is apropos. See also note 21 to Berberova's letter of 21 June (1947?).

32 See note 29 to Berberova's letter of 16 July 1947.

33 Berberova wanted to send to Rittenberg a copy of Anna Achmatova's Četki (1914). See my introduction, 6 . 
и есть тоже невозможно, и вообще очень, очень тягостно - главное, продолжается уже неделю и неизвестно, когда кончится.

Добужинский - петербуржец, и мы будем с ним говорить о Петербурге. ${ }^{34}$ Уехали ли Вы в отпуск, или гуляете по Стокгольму? Я вероятно останусь в Париже - на юг ехать финансов нет, и потому: разве у меня уже не было отдыха в Швеции? Пора и честь знать...

Жму Вашу руку.

НБерберова

34 The artist Mstislav Dobužinskij (1875-1957) was of course particularly important to Berberova as a living link to Petersburg. 
Дорогой Сергей Александрович,

простите, что долго Вам не писала. Сегодня пришло Ваше милое письмо, а на прошлое, длинное, я не ответила. Теперь пишу ответ на оба. Причиной тому не моя забывчивость, а дела, нахлынувшие так сразу в Париже. Потом было нестерпимо жарко и я, т.к. финансов не было ехать на юг /где было совсем не жарко, между прочим/, поехала в деревню на две недели с Б.К. Зайцевым, моим большим другом, и его женой, с которой тоже очень дружна. ${ }^{35}$ Люди они уже пожилые, но мы весело и трудолюбиво проводили дни. Писали, гуляли, отдыхали. Затем я вернулась. Сейчас занята будущей моей квартирой, в которую надеюсь переехать через две недели, а также всякими литературными делами на зиму, т.к. начинается осень и пора подумать о «плановом зимнем хозяйстве«.

Перевод мой «Вечного мужа« Достоевского выйдет скоро /и я Вам его пришлю/, я завалена корректурами. ${ }^{36}$ «Блок« тихонько просачивается в публику. Пресса его хвалит. ${ }^{37}$ Я же пишу роман, - ax, это очень страшно, писать роман! ${ }^{38}$ Увлечена очень, но отрываюсь для всякой другой работишки. Надеюсь в весне кончить - он уже весь в голове, со всеми деталями. Будет он не совсем обыкновенной постройки - пять действующих лиц рассказывают о себе всякие истории...

Вчера получила от своего верного друга, Греты Герелль, ${ }^{39}$ вырезку, невероятно осчастливившую меня: вообразите себе, дорогой друг, секретарь Шведской Академии, Остерлинг, разразился о моем «Блоке«

35 Berberova's friend the prosaist Boris Zajcev (1881-1972) and his wife Vera.

36 Fedor Dostoïevski, L'eternel mari, translated by Nina Berberova and Mina Journot, with a foreword by Berberova, Paris 1947.

37 See note 28 to Berberova's letter of 16 July 1947.

38 Mys bur'.

39 Greta (Margareta) Gerell (1898-1982), Swedish Anthroposophical artist, student of André Lhote in Paris. In 1931 she began a close friendship with Dmitrij Merežkovskij and especially Zinaida Gippius. See Temira Pachmuss, Thought and Vision. Zinaida Hippius'Letters to Greta Gerell (Frankfurt am Main 2004). On Gerell's iniative, Berberova came to Stockholm not only in 1946 and 1947 but also in 1948. She became very friendly with Gerell and complains throughout her correspondence with Rittenberg that Gerell is not in touch with her enough. On Gerell's art see Die Malerin Greta Gerell, mit Texten von Lillian Schacherl und Walter von Samson-Himmelstjerna, Munich 1969, and Greta Gerell, Med egna ord, Stockholm 2007. 
статьей - громадной и лестной - в «Стокгольмс Тиднинген. « ${ }^{40}$ Очень Вас прошу достать этот номер /от 2 сент./ и прочесть это и за меня порадоваться. Кстати, спросите при случае Кнутсона, получил ли он мою книгу; я послала ее ему еще в июне, и с надписью.

Вы простите меня, что я пишу все о себе. Кажется, все писатели таковы. Говорят, что Фон Визин ${ }^{41}$ совершенно не выносил, когда говорили при нем не о нем. У Державина ${ }^{42}$ есть запись: вчера был Фон Визин и заснул, так как говорили о Сумарокове. ${ }^{43}$ Каково?

Вспоминаю о Вас и наших прогулках. Совершенно уверена, что в июне приеду опять - разве что стрясется что нибудь с Европой. Это любопытно, что «Орион« проник в Финляндию. Я непременно скажу об этом редактору - ему будет интересно. Спасибо за обещание присылать вырезки из Стокгольмских газет /россику/ - это очень интересно и я воспользуюсь непременно ими для газеты. Как я Вам уще говорила, можете иногда прислать и корреспонденцию. Видите ли Вы нашу «Русскую мысль«? Она немного провинциальна, но это от бедности: она вообще бедна, благородна и горда, как когда то были девушки. Я работаю там много, денег не вижу. Однако, виды на будущее довольно отрадны.

Я с Вами совершенно согласна по поводу стихов Ходасевича. И про Газданова ${ }^{44}$ я тоже думаю, как Вы. Вообще я чувствую во многом с Вами униссон... и даже собираюсь перечесть Апухтина, ${ }^{45}$ чтобы по-новому его оценить. И про Германа тоже думаю, что это книга хорошая. ${ }^{46}$ Жму Вашу руку и шлю привет. Не сердитесь, что пишу редко.

НБерберова

$40 \quad$ Anders Österling (1884-1981, Secretary of the Swedish Academy since 1941), "Alexander Blok," Stockholms-Tidningen, 2 September 1947, who writes: "It is not clear whether the Russian lady knew her countryman personally, but what she obviously knows well are his contemporary milieu and the circles in which he moved." He notes that the biography ends with a number of poems in Berberova's interpretation. He thinks it possible that despite the translation difficulties, one can feel "the hot pulse in his (Blok's, M.L.) emotional life, the feverish fullness of expression in his filigree images."

41 Denis Fonvizin (1745-1792).

42 Gavriil Deržavin (1743-1816).

43 Aleksandr Sumarokov (1718-1777).

44 Gajto Gazdanov (1903-1971), highly original émigré novelist influenced by Proust.

45 Aleksej Apuchtin (1841-1893), poet of the 1880s, whose lyrics were often set to music.

46 Berberova seems to be alluding to a new work by Rittenberg's brother-in-law, Soviet writer Jurij German (1910-1967). 
Дорогой Сергей Александрович,

Вы наверное на меня рукой махнули: на три письма я не ответила. Не поблагодарила Вас за вырезки, не послала «Русского Сборника«... Словом - вела себя ужасно. А между тем мне было так скверно, что я даже рассказывать Вам всего не хочу. Временно я переехала, но адрес тот же: я взяла комнату на пэтом этаже того же дома, крошечную комнату, со светом, но без воды... Словом, жить так долго не смогу, ищу по прежнему, ничего не нахожу, но сейчас немного успокоилась: живу, как студент, одна, в тишине, и пора уже летом заняться, а то я два месяца только боролась с жизнью и ни одной путной мысли в голове не было. Да, блаженны одинокие, ничем несвязанные, забытые на шестых и седьмых этажах люди, - ибо их есть царствие небесное.

«Русский сборник« /разве он «в честь Бунина и Бенуа?« - я не знала/ вышлю. ${ }^{47}$ Сколько он стоит - не знаю, но Вы мне пожалуйста ничего не посылайте, отдадите при случае в Стокгольме. Книгу Булич ожидаю с нетерпением. ${ }^{48}$ Хочу дать о ней отзыв в русской газете. К сожалению, просьбы ее исполнить не могу: следить за рецензиями на ее книгу не чувствую себя в силах. Пусть попросит Адамовича прислать ей его рецензию, если он будет о ней писать. ${ }^{49}$ Больше мест никаких нет. Пусть пошлет книгу Зайцеву, на адрес «Русской мысли« и Смоленскому ${ }^{50}$ в «Орион«, 20, рю Лакретелль, Париж 15.

Вы мало мне пишете о себе, милый Сергей Александрович, куда ходите, кого видите? Или все - служба да уроки, да чтение? Может быть оно впрочем и чудно, я сама так сейчас живу: мало кого вижу, чувствую в себе возможности одичания, и под старость лет - отшельничества. Ах, хорошо это, свободная холостецкая жизнь! И великое дело - ключ от собственной двери. Разве нет?

Но жизнь идет. И между прочим, был вечер Бунина, на котором он читал, совсем старый и белый, сухой, сердитый и морщинистый, жуя губами, кряхтя, стихи и прозу. И то и другое было не очень хорошего

47 Russkij sbornik, kn. 1, Paris 1946, dedicated to Ivan Bunin's and Aleksandr Benua's (Benois') jubilees. Practically the entire writers contingent in Paris participated, although not Berberova.

48 Rittenberg's Helsinki friend Vera Bulič (1898-1954), whom he often promoted, had just published her new poetry collection Burelom.

49 Georgij Adamovič (1892-1972), poet, critic and translator, once close to the Acmeists, founder of the group "The Paris Note."

50 Vladimir Smolenskij (1901-1961), leading émigré poet. See Kursiv moj, 319-321. 
сорта и выбор был неудачный. ${ }^{51}$ Это все очень далеко от меня - и верно от Вас. Уже тридцать лет тому назад это было далеко от нас, правда? А теперь и подавно.

Жизнь здесь стала очень тяжелая, почти непосильная. Поворот вправо на здешних выборах немного укрепил политическое положение в стране, но экономическое положение все ухудшается: ни угля, ни масла сливочного /верите ли, более двух месяцев его не видели!/, ни других нужных вещей, а что есть, то до того дорого, что годится только избранным. Зима немножко страшит.

Но мужество не потеряно, и значит жить можно. Спасибо Вам, что пишете мне и не сердитесь, что я молчала. Мне было очень плохо, совсем отчаянно плохо, как бывает два-три раза в жизни, да и то не у всех. Но теперь лучше, хотя все не расхлебано еще, жизнь последних лет не расхлебана. Это не так все просто сделать.

Жму Вашу руку и дружески думаю о Вас.

НБерберова

51 Bunin held a literary soiree in Paris on 23 October 1947. 
Дорогой Сергей Александрович,

сегодня получила Ваше письмо и сегодня же отвечаю - так Вы меня тронули Вашим предложением послать мне посылку. Спасибо Вам. Конечно, выкиньте это из головы! Не для того Вы до десяти часов вечера работаете, чтобы деньги свои бросать на такие «удовольствия«. Вот если бы Вы были пенсионер, тогда бы я не только посылку приняла, но приехала бы к Вам гостить на неопределенное время. Но, шутки в сторону. Мне хочется просить Вас сделать один опыт: я прошу Вас выслать мне какой нибудь пустяк: коробку макарон, в один фунт, или коробочку сыра в одну-две кроны. Пошлите не заказным, простым, и по почте, конечно, не по воздуху. Посмотрим, что из этого выйдет. Это, само собой разумеется, пойдет в рассчеты наши с Вами. На будущей неделе высылаю Вам русский сборник - он стоит вероятно 250 или 300 фр., что по м о и м рассчетам составляет 5-6 крон. Если Ваша посылочка дойдет - что вполне возможно, т.к. крадут, по моим наблюдениям только роскошные посылки, - то я попрошу Грету Герелль мне выслать к Рождеству мармелад господина Финдуса, которого я очень люблю. 52

Вы пишете о Булич. Неужели она, в ы б р а в сидеть за жел. занавесом, не получает удовлетворения от этого выбора? Неужели ее книга не читается в России? Неужели русская критика о ней не пишет? $?^{53}$ Здесь в эмиграции известно, что она в ы б р а л а, и это конечно сильно ей вредит. Теперь здесь настроение такое стало отчетливое, что «кто не с нами, тот против нас«, да и события идут довольно быстрым ходом - боюсь, и радуюсь...

О многом хочется написать Вам, но ограничусь только несколькими строками о самой себе: как Вы может быть знаете, я была замужем. С 1943 года, т.е. четыре года, я н е м о г л а освободиться от человека, мне ставшего совершенно чужим. ${ }^{54} \mathrm{~B}$ то же время я сама запутала себя уже совсем по другому. Наконец, этой осенью, я решила: «ду

52 Findus is a familiar Swedish food brand whose name is an anacronym derived from "FruktINDUStri" ("Fruit industry"). Findus (possibly featuring a man in its advertisements) was among the first companies to offer canned and frozen products.

53 Berberova is commenting sarcastically on Vera Bulič's friendly attitude toward the Soviet Union.

54 Berberova's second husband, the writer Nikolaj Makeev (1888-1973), from whom she had now painfully separated. 
муст дайн лебен эндерн ${ }^{55}$ И сделала это. Сейчас сижу в маленькой комнате, без всяких удобств, но о д н а, с в о б о д н а, как птица. Надеюсь к Рождеству устроиться лучше. Понемногу успокаиваюсь, в этой тишине и в этом одиночестве. Сразу оборвала в с е нити. Впрочем, конечно, не сразу, но вижу уже конец всей своей прежней жизни. И это хорошо, потому что мне н а д о жить одной, такова моя природа.

Если найду комнату с кухней, если будет работа - тогда буду весела, как чижик. Вот Вам и проза жизни моей.

У нас теперь два раза в неделю нет электричества до семи часов вечера. Пишу Вам при свече - сейчас половина шестого. Пока не холодно, но когда наступят холода, то без электрич. радиатора будет не весело. Ах, вообще не весело жить, и вместе с тем - страшно весело. Бываете ли Вы в Тиволи? Едите ли сосиски там?

Пока прощайте, милый друг. Ваши письма - прелесть остроумия и я очень ценю нашу дружбу. Будем же ее продолжать!

Крепко жму Вашу руку.

НБерберова

55 A quote from Rainer Maria Rilke’s sonnet “Archäische Torso Apollos" (1908), which ends: "denn da ist keine Stelle,/ die dich nicht sieht. Du musst dein Leben ändern." 
Париж, 24 нояб. 1947

Дорогой Сергей Александрович, сегодня пришло Ваше письмо. Я очень Вам благодарна за Ваше желание послать мне посылку, но повторяю, что это не надо. Я прошу Вас выслать только для пробы одну коробку макарон - по почте. Посмотрим, что из этого выйдет. Ни сахару, ни кофе ни в коем случае не посылайте. Этого не надо вовсе!

Получила книгу Булич. ${ }^{56}$ Спасибо. Она меня разочаровала. Лучше «Фонтан« и несколько стихотворений в начале книги. «Бурелом« же и «Верность« поразили меня однообразным и очень немузыкальным звуком. Все это лишено своеобразия и не звучит, кроме «Папироса Беломорканал« - но по этому пути она не пошла, а пошла по проторенной дорожке, кот. сейчас кажется совсем бледной и даже скучной. Жаль. Писать я о ней не буду, т.к. должна бы была писать о стихах «по существу« - а это ей будет неприятно. Бог ей судья, ее дело пойти туда, куда она идет: в следующей книге она воспоет Сталина, еще в следующей - захочет сделать диверсию, и тогда ее «разъяснеет«.

Но я читала (клянусь в этом!) без предвзятости, и нашла что не столь ее тема, сколь ее «звук« стал плох. Жаль, жаль.

Сегодня посылаю Вам Русский Сборник. Он оказался гораздо дешевле, чем я думала: всего 150 фр. т.е. 3 кроны. Там я разрезала Ремизова Вы на меня за это не посетуете. ${ }^{57}$

У нас тут жизнь невеселая из-за политических событий, за кот. Вы вероятно следите. Сегодня опять - забастовки. Не знаю, уйдет ли это письмо.

Милый Сергей Александрович, я опять прошу Вас кроме спагетти и - может быть - сухого молока ничего мне не посылать. Сахар у меня есть, т.к. я все время пила кофе с чудным шведским сахарином. Кофе нам выдают, и т.к. есть цикорий, то мне хватает. Чай почему то уменьшается очень медленно и я не страдаю от его отсутствия. Словом, пожалуйста себя не лишайте ничего и аккуратно ведите счет моему долгу.

Я напишу Вам большое письмо приблизительно дней через 10 - я кажется пережду. Пишите все же сюда, если выдумаете писать.

\footnotetext{
56 Burelom.

57 See note 47 to Berberovas letter of 6 November 1947. Aleksej Remizov (1877-1957) contributed to Russkij Sbornik with the autobiographical text "Myškina dudočka."
} 
Иногда я задаю себе вопрос: не придется ли мне отсюда уехать? И не могу на него ответить... Скоро год как я выехала в первый раз в Швецию. А день Lucia - наше с Вами знакомство.

Как Вы можете заметить - у меня Sehnsucht. ${ }^{58}$ Жму руку. 
15 дек. 1947

Дорогой Сергей Александрович, Ваши письма получила. Спасибо. Наконец сегодня, только сегодня, смогла отправить Вам Русс. Сборник - после забастовки сначала пошли письма, потом пакеты, потом книги. Спасибо за посылку - не получила еще, но наверное получу. Я переехала, у меня новый адрес, но там, на Miromesnil, остался мой законный муж (!) и он ее мне сейчас же доставит.

Итак - я переехала, и свободна, как ветер. Работа есть кое-какая. Надежды тоже. События были здесь довольно нешуточные, однако все слава Богу и думаю, что дотация выправится - уж очень умны здесь люди, в частности - правители.

У меня маленькая комната и крошечная ванная. На днях перевезу книги свои - это мое главное имущество. К Нов. Году выйдут две мои книги по французски - перевод «Вечного мужа« Достоевского ${ }^{59}$ и, конечно, «Чайковский«. ${ }^{60}$ Работаю сейчас над письмами Пушкина. Милый друг, у меня к Вам громадная просьба: не в службу, а в дружбу, пошлите 23-го утром Fröken G. Gerell к Рождеству следующий предмет: кусок зеленой елки со вставленной в нее свечой, разукрашенной бантом. В прошлом году эта трогательная вещь стоила 10 крон - и за эти же деньги еще и 2 красных гриба оживляли пейсаж. К нему, т.е. к этому предмету, Вы приложите сию карточку - и запишите в книжечку мой новый долг Вам, кот. отдам весной, когда приеду (или выслать Вам книг?). Не знаю, как Вас и благодарить! Вы знаете, как мне хочется сделать какой нибудь милый жест в сторону моих шведских приятельниц, потому не сердитесь, что надоедаю Вам такой просьбой. Адрес Греты: Fröken G. Gerell, Gamla Brogatan, 32. В магазине они и пошлют, но надо сделать это 23-го, т.к. 24-го Грета идет к другой Грете в Дротнингхольм. Вы представляете, какое впечатление это произведет на них двух? Этого то мне и хочется.

Спасибо. Жму Вашу руку. Если будет стоить дороже - пусть это Вас не остановит (если, конечно, Вы в силах мне авансировать такую сумму?). О, дружба, это ты! ${ }^{61}$ Ты слаще любви и прочнее камня, и живительней влаги в знойный день!

$59 \quad$ See note 36 to Berberova's letter of 4 September 1947.

60 Berberova's biography of Čajkovskij was first published in 1936. A new edition appeared now in pocket format: Tchaikovsky. Histoire d'une vie solitaire, Paris 1947. Mina Journot and the author collaborated on the translation.

61 The last line in Vasilij Žukovskij’s poem "Družba" (1805). 
9 бис рю де Магдебур. Париж 16

20 декабря 1947

Дорогой Сергей Александрович,

вчера вечером - посылка... Не могу сказать Вам, до чего я была тронута. Не говорю о материальной стороне дела - это, конечно, мой долг Вам и тут не может быть спора: у нас с Вами рассчеты были и будут. Но говорю о Вашей заботе, о том времени, кот. Вы потратили, о мыслях, которые заняли. Все это я умею ценить, и прямо скажу: тронута ужасно. Спасибо Вам, милый Сергей Александрович... Но Вы меня не послушались и прислали сахар, кот. Вам нужен с а м о м у. Это нехорошо. Зато молоку и Финдусу я была невероятно рада. Самое грустное это у нас утренний завтрак. Понимаете; вообще почти все можно достать, вопрос денег. Значит, обед вообще готовится - всякому по средствам своим. А вот утренний завтрак - даже богатые люди ничего с ним поделать не могут. Начисто нет молока, и приличного варенья. (Я написала «масла«, но если Вы вздумаете мне его прислать я страшно рассержусь, - ни в коем случае этого не делаете, уже потому хотя бы /!/ что посылка идет слишком долго и может все погибнуть). Так вот и пьем черный кофе и едим хлеб. Это очень, конечно, выглядит печально. А сегодня я встала и пила уже утром чудное Ваше молоко и ела умопомрачительный Финдус ${ }^{62}$. Кланяйтесь ему, когда увидите.

Я недавно еще обременила Вас просьбой, насчет елки-свечки Грете. Надеюсь, Вы не очень ворчали на меня? Хочу Вас спросить: не хотите ли Вы Блока - сов. издание, избранный, хороший, но некрасивый? Или что нибудь другое? Я бы так и надписала книжку: Сергею Александровичу на елку... Воображаю стокгольмские елки! А тут идет дождик.

Итак, я живу самостоятельно, в тепле, книгах, работе. Квартал очень хороший и вообще - все как будто налаживается. Но дает себя знать усталость и нервность последних месяцев. Многое я расскажу Вам при встрече, пережить мне пришлось вещи не только не банальные, но и просто отчаянные, которые могли скрутить в бараний рог любого. Думаю, что вылезу из всего этого, хоть и с помятыми боками. Хотелось бы уехать куда нибудь на время - это было бы очень полезно, но конечно сейчас об этом и думать не могу: жизнь дорожает с каждым днем, бороться за нее трудно. Издатели дремлют. Однако, есть кое

62 Berberova's Swedish favorite marmalade. See note 52 to Berberova's letter of 13 November 1947. 
что по Пушкину, над чем я начала трудиться. Вообще, если бы хоть немножко больше и аккуратнее платили, то можно было бы дышать: сами посудите: в «Русской мысли« к моим ногам /!/ так сказать положена целая страница /литература, кино, театр и даже выставки/. Пиши, сколько душе угодно. Но платят одну десятую того, что должны, ибо бедны ужасно. Сейчас поляки просят для их толстого журнала статью о В.Ф. Ходасевиче. На это тоже уйдет время. Но это тоже почти даром. И так все. Ах, я знаю, что Вам пришлю /как только получу/ - новый, 17-ый номер «Нового журнала« из Нью-Йорка с моей повестью... ${ }^{63}$ Вы заметили, что хитрые люди делают подарки, какие им самим приятны?

А Вы все работаете до десяти часов вечера, страховое общество, уроки? Устали наверное? На праздниках может быть отдохнете немножко? Выйдете в свет? Здесь настроение не праздничное, всем как-то тревожно, но должна сказать, что я скорее радужно смотрю на будущее и каждый день в нашей трудной жизни вижу признаки оздоровления, - a особенно в сегодняшнем расколе рабочего синдиката.

Представьте себе, что я почти ничего не читала в последние месяцы и мало кого видела. Здесь было три литературных вечера: Бунина, Тэффи и Зайцева. Увы, мало что осталось от первых двух! Бунин - стар и слаб, до него уже мало что доходит и он как-то оглупел /простите!/ и от старости стал совсем безответсвенным. Тэффи тяжело больна, началось это еще на вечере, от волнения. ${ }^{64}$ Зайцев же, мил и нежен как всегда, читал о Жуковском, поэте ему очень близком, не стихами даже, а самым своим характером, обликом, жизнью. ${ }^{65}$ Публика была тоже не молодая, на вечере, и все здесь «в массе« идет к естественному концу, но в единицах - еще живо. Оттого единицы так и одиноки.

Не кажется ли Вам, Сергей Александрович, что странная судьба моя привела меня в Стокгольм, который стал дла меня «городом дружб«? Окно мое выходит - прямо на Швецию /северо-восток/.

Теперь хочу Вам пожелать счастья в Новом году и поздравить с праздниками. Будьте здоровы, спокойны и, по возможности, счастливы, и еще хочу, чтобы мы свиделись.

Крепко жму руку.

НБерберова

63 The short story "Voskrešenie Mocarta," Novyj žurnal 17 (1947).

64 Tẻffi (pseud. of Nadežda Bučinskaja, née Lochvickaja, 1872-1952) was now the leading female representative of the literary émigrés in Paris.

65 Boris Zajcev's Žukovskij appeared in Paris in 1951. 
9 бис рю де Магдебур. Париж 16

2 января 1948

Дорогой Сергей Александрович,

с Новым Годом! Не больны ли Вы? От Вас что то давно не было писем. Но зато я получила от Греты Герелль известие, что ею была получена чудная елка к Рождеству. Как Вас благодарить за Ваше милое исполнение моей просьбы? Сюрприз удался на славу. Чтобы Вас немножко порадовать к Рождеству, я послала Вам книг: Кузмина, два томика Терапиано ${ }^{66}$ и один Поплавского. ${ }^{67}$ Надеюсь, что они все пригодятся Вам.

У нас здесь было довольно грустное Рождество. В магазинах все есть, яства роскошнейшие, французские, но цены совершенно невозможные, и... мимо, читатель, мимо... Дождик, теплый и непрестанный, идет уже месяц. Какая то ложная весна в воздухе, ложная, потому что, конечно, через неделю наступят холода и придет поздняя зима, как полагется. На моей вышке, где я уже месяц, всегда туман. Но один раз, под вечер, вдруг небо просквозило лазурью, солнце вышло из за туч и я на мгновение увидела над крышами - Монмартр /окно выходит на северо-восток/, Сакре-Кэр, озаренный, как Град-Китеж. Был неожиданный сюрприз. Значит, весной, я его буду видеть все время.

Настроение так себе. Читаю Ницше, представьте себе, - что нашлось дома, единственный том - «Се человек« /автобиография/; «я боюсь не одиночества, я боюсь множественности«, - говорил этот человек, и это могу сказать и я. ${ }^{68}$ Страшно устала от людей - конечно, не посторонних, а «близких«. С каким бы удовольствием вырвалась в Стокгольм на время, но нельзя: на сей раз меня ждет там не тысяча крон, как бывало, а только пятьсот, и надо их придержать к лету, чтобы воспользоваться приглашением «Грет« и опять побывать на Хеммаре. ${ }^{69}$ Но с каким удовольствием я поеду - знает один лишь мой Ангел-Хранитель, который, кстати, говоря, не очень хорошо заботится обо мне последнее время.

66 Jurij Terapiano (1892-1980), émigré poet, prose writer, translator and critic.

67 Boris Poplavskij (1903-1935), émigré poet and prose writer, influenced by Rimbaud, the surrealists and Blok. See Kursiv moj, 66.

68 Nietzsche's Ecce Homo (1887), the last work he wrote before the onset of his illness.

69 Berberova appears to have been paid for her Čajkovskij biography in annual installments. 
Работаю над Пушкиным по-французски и думаю серьезно сесть за роман /который придется, вероятно, сперва издать по-французски/. Это будет странный роман, даже не роман вообще. Это будет некая «документация« о пяти людях, о пяти человеческих совестях. ${ }^{70} \mathrm{~B}$ газете «нашей« пишу мало: во первых, она делается понемногу реакционней, что совсем мне не по вкусу, а во вторых - провинциальной, захолустной, какой то «болгарской«, - Вы понимаете? Ах, где наша «великодержавность«, прости Господи! Она умерла, и не только в эмиграции, ее нет и в сов. дипломатии.

Как Вы провели праздники? Как Вы настроены? Верно, как все в Вашей стране, ждете уже весны... Давайте ждать ее вместе. Она н ав е р н о е будет хорошая.

Жму Вашу руку.

НБерберова

70 Mys bur'. 
30 января 1948

Дорогой Сергей Александрович,

Все Ваши письма получены. Не писала я Вам за недосугом. У нас целый день льет дождь и вот уже 3 раза за январь месяц была гроза! А то выглянет солнце и пахнет весной. Удивительный климат! События идут своей чередой; финансовые меры волнуют почти всех - но не меня, т.к. денег у меня мало и от того мало и забот о них. Хорошо это.

Вышел «Новый Журнал« с моим рассказом. ${ }^{71}$ Я Вам его вышлю. В нем есть и любопытные статьи, и беллетристика хорошая - все таки это большая радость, что он существует.

Ваши слова о «Рус. Мысли« не могли меня обидеть, - неужели Вы можете думать, что я столь обидчива? Да, она реакционна и захолустна. Но каждый день в редакцию приходит до 10ти писем читателей: восторги по поводу захолустности и просьбы быть еще реакционнее! Мне бы хотелось перечесть Чаадаевские «Философские письма«-Вы видите, каковы мои настроения $?^{72}$ Для меня - он был во многом прав. Я не питаю ненависти к России и русскому народу (о нет, особенно не к народу!), но... что-то здесь у меня требует пересмотра... Словом, чувствую себя в каком то «кризисе«... Жму Вашу руку.

НБерберова

71 “Plač,” Novyj Žurnal 20 (1948).

72 Petr Čaadaev (1794-1856). 
20 февраля 1948

Дорогой Сергей Александрович,

у Вас квартира! Как я рада! Никто больше меня не может Вам сочувствовать в этом: я только теперь обрела мир и покой, день мне кажется - несмотря на постоянную работу, на многочисленные материальные заботы, на тьму будущего - почти праздником, так хорошо и благотворно для меня одиночество. Так значит, я приду к Вам в гости весной? Вот то будет хорошо. Но самое удивительное зато то, что Вы живете в таком чудном месте, на набережной... А еще удивительнее другое: Вы живете в том же доме, где живет вдова Стриндберга, Гариэтта Боссе, у которой я была в гостях... Эта маленькая старушка, впрочем еще не дряхлая, накрашенная и в корсете, надушенная парижскими духами, и одетая по моде. Как удалось Вам найти себе пристанище, да еще в таком месте? Нет, правду говорят, что русский человек в воде не тонет и в огне не горит. ${ }^{73}$

Есть ли у Вас мебель? Или Вы спите на полу и едите на подоконнике? Это тоже бывает. Я знала одного человека, у которого было только пианино и больше ничего. Когда бывало холодно, он укрывал пианино одеялом, а сам ложился подле, на пол, как пес, накрывшись пальто. Воображаю, как Вы вечером гуляете по Вашей квартире и вслух читаете стихи Гумилева ${ }^{74}$ и Кузмина ${ }^{75}$ /а хоть бы и Апухтина - Вы сам себе хозяин!/, поглядывая изредка в окно, где виден мост громадный, рукав моря и пароходики. Впрочем, сейчас все это оковано льдом.

73 Berberova held August Strindberg in exceptionally high esteem. She viewed him as the originator of the new and central genre of ruthless authorial self-revelation, particularly in Le plaidoyer d'un fou. When she arrived in Stockholm in November 1946 she had two wishes: first, to meet the actress Harriet Bosse (1878-1961), who was Strindberg's third (and last) wife from 1901 to 1904. Second, she wanted to put flowers on Strindberg's grave in Norra Kyrkogården cemetery. Greta Gerell arranged the meeting with Harriet Bosse. It did not go so well for Berberova. Bosse was arrogant and distant. Eventually Gerell and Bosse, however, did become friends. Gerell painted her portrait in the role of Eleonora in Strindberg's Easter. In 1958 they traveled together to the Canary Islands. (See Gerell, Med egna ord, Stockholm 2007.) Interestingly enough, Rittenberg was offered a one-room apartment in her house on Norr Mälarstrand, so the two became neighbors.

74 In Rittenberg's archive there is a copy of Nikolaj Gumilev's collection of poems Čužoe nebo (1912), published in Berlin in 1936, with the following dedication: "Dorogomu Sergeju Aleksandroviču na novyj - 1948 - god. N.B. Pariž”.

75 Michail Kuzmin (1875-1935). 
И у нас зима, поздно, но все таки настала. Сегодня было -11 утром, и у меня на окнах «цвели морозные пальмы«. Центральное отопление чуть живо, и мне холодно. Но это, надеюсь, не на долго.

Отвечаю Вам на Ваши вопросы. Касательно «разочарования в русских людях мы с Вами когда нибудь обстоятельно поговорим. Сейчас скажу тоько вот что: недавно /15-го/ вечером в «радио Пари« был «час о русской литературе«. Представьте, все было очень прилично, и даже больше - превосходно. Читали письмо Бунина, пластинку, наговоренную Ремизовым о снах /по французски/ и диспут о литературе Вейдле ${ }^{76}$ Шлецера ${ }^{77}$ и Адамовича. Последний был так себе /акцент невозможный и благоглупости ни туда, ни сюда/, но Вейдле был замечателен, тактичен, умен, тверд /политически/ и вообще прекрасен. ${ }^{78}$ И вот что он сказал, что кажется мне чрезвычайно справедливым: в русской литературе отсутствует целая отрасль, которая так развита у французов: это отрасль мыслительной, рассуждающей литературы, типа Паскаля, Ницше. Не философия в прямом смысле /которой тоже нет/, но вот это самое, чего так иной раз хочется, и чего в о в с е нет у нас. Был Чаадаев, - кончилось трагически. Выкорчевывая идейки, царское правительство замучило таких людей, а о большевиках и не говорю.

Вы спрашиваете про Сирина. Сирин /Набоков/ давно в Америке, писать бросил, по крайней мере по русски. А ушедший из Союза Сирин был Председ. Союза Сов. Патриотов - никому неизвестный, но чрезвычайно активный мерзавец. ${ }^{79}$

Что до Вашего желания проводить параллели между французскими и русскими писателями и поэтами, то конечно, это занятие безобидное, когда его делают в разговоре люди, между которыми существует понимание общих и главных вещей, но мне кажется в предисловии к Антологии, ${ }^{80}$ когда автор Антологии хочет объяснить Языкова, он не должен сравнивать его с Верлэном - человеку не знающему Языкова, это ничего не даст, это, так сказать, совершенно зря, и получается дешевка. ${ }^{81}$ (Даже пошлость, как я писала.) Я вот когда Вы мне говорите, что Чехов - Мопассан, то я знаю, что кроме этого о Чехове и Вы и я

\footnotetext{
76 Vladimir Vejdle (1895-1979), literary and art critic.

77 Boris Šlecer (de Schloezer, 1881-1969), musicologist and music critic.

78 Berberova had constantly trouble in getting along with Adamovič.

79 S.N. Sirin (Roščin), journalist, member of the presidium of the Union of Soviet Citizens (Sojuz sovetskich graždan), deported from France in 1947.

80 D.S. Mirsky, Anthology of Russian Poetry, London 1924.

81 Nikolaj Jazykov (1803-1846), Romantic poet, Puškin's friend.
} 
можем сказать еще тысячу вещей, и тогда это вполне допустимо. Подумайте, Сергей Александрович, ну что если Вы русскому человеку, никогда о Гельдерлине не слыхавшему, скажете, что это немецкий Батюшков? ${ }^{82}$ Неужели он что нибудь узнает таким способом о Гельдерлине больше, нежели он знал? Со всеми Вашими параллелями я, в сущности, согласна, кроме одной: по моему Боратынский питательнее Виньи... ${ }^{83}$ А впрочем, может быть для Вас это и иначе.

Здесь, во Франции, присходят вещи странные и мало приятные... Но писать об этом сейчас не хочется. Все это может быть в будущем роковым узлом, где Европа задохнется раз и навсегда. Но рядом с этим идет глубокая жизнь единиц, и об этом мне хотелось бы рассказать Вам. Назову два явления: пьеса Монтерлана «Le Maître de Santiago«, в театре Эберето, хоть и с сильным католическим душком, но говорит о каких то чрезвычайно важных и глубоких метаморфозах, происходящих в умах лучших людей Франции. Действие происходит в 16-ом веке, а звучат иные слова остро, как если бы разговор шел о нашем времени. Второе: новый журнал, «La Table Ronde«, где пишут люди умные, грустные, бесстрашные и пронзительные. Это - Франция сегодняшнего дня, с ее отпором большевизму, пониманием глубокой трагедии будущего, социальных неправд, утери религии; с ее обретенным смыслом страдания. ${ }^{84}$

Были ли Вы на выставке Греты Герелль? Послала ли она Вам приглашение? Я ее просила об этом.

Пока прощайте. Жму Вашу руку.

НБерберова

82 Konstantin Batjuškov (1787-1855).

83 Alfred de Vigny (1797-1863), French poet, dramatist and novelist.

84 Henry de Montherlant (1896-1972), French writer, one of Berberova's favorites. His plays were extremely popular in the years after WWII. 
9 бис рю де Магдебур. Париж 16

3 апреля 1948

Дорогой Сергей Александрович,

не по невниманию, не по лени, - я не писала Вам исключительно по какой то гомерической усталости. А в Вашем сегодняшнем письме именно про это самое и говорится: это усталость весенняя, а кроме того, конечно, - нервная. Как мне понятно и близко все то, что Вы пишете о нашем общем европейском будущем! Мы поговорим с Вами об этом при свидании, а сейчас расскажу Вам о своих планах и даже... попрошу у Вас совета.

Моя милая Грета Герелль, после двух выставок, хочет приехать во Францию на месяц. Она хочет прибыть 20-го апреля, прожить в Париже несколько дней, а затем приглашает меня ехать с ней на испанскую границу, в дивные места. После этого она предлагает вернуться в Париж, прожить неделю или вроде того, и вместе ехать в Швецию - хотя бы до 15 августа, т.к. она считает, что мне необходимо в этом году пожить спокойно и уютно в доме г-жи Асплунд. ${ }^{85}$ Я пока, как будто бы, согласилась, но боюсь, что это с моей стороны становится уж слишком неделикатно! Что Вы думаете об этом, Вы, который знаете шведские порядки? Надо Вам сказать, что оба раза, когда я приезжала, у меня было по 1000 крон, и я тратила, делала подарки, покупала себе вещи. Сейчас у меня 500 кр. Значит, я могу только иметь на карманные расходы, если останусь два-три месяца. Кроме того, здесь, в Париже, живу более чем скромно и ездить на свой счет не могу по жел. дорогам, которые бешено дороги. Значит, мне придется поступить на полное иждивение Греты /что она и хочет/. Возможно ли это? Конечно, мне очень хочется всех этих удовольствий. Но я категорически написала ей, что из Парижа в Стокгольм поеду о д н а, после нее - т.к. я еду третьим классом, а она вторым, и чтобы не было никаких неудобств из за меня. Она на это ничего не ответила, вероятно об этом еще будет разговор. Пишу Вам все это откровенно, потому что считаю Вас своим другом. Здесь никого спросить не могу: тут люди настолько огрубели, что все единогласно мне ответят: ну конечно надо ехать, чего там церемониться!... А меня это не убедит. Сообщите мне Ваше мнение и как бы Вы сами поступили.

85 See note 20 to Berberova's letter of 20 June 1947. 
Словом, так или иначе, а в начале июня мы увидимся. Если поездка на юг не состоится, то я поеду в Швецию даже в в конце мая, с тем, чтобы по приглашению все той же Греты , сделать с ней маленькую экскурсию куда-нибудь на север Швеции. Мы, значит, увидимся во всяком случае - и до отъезда моего на остров Хеммаре, и после лета - перед возвращением в Париж остановлюсь я в ателье на Гамла Брогатан. Ах, как это будет чудно. Но... ни слова пока более, а то слишком захочется ускорить время.

Две недели на меня напала хвор: представьте, что у меня болела правая рука, так что я не могла писать - ни пером, ни на машинке. Куда как весело! А сейчас я так устала, что почти весь день лежу. Сегодня ночью проснулась и думала о том, что для меня теперь куда-нибудь выйти - му́ка, и не становлюсь ли я анахоретом? Впрочем, как раз на этой неделе была в одном поэтическом кружке /о кот. расскажу лично/. Там, между прочим, видела Г. Иванова, которому рассказала о Вас. Он сказал, что хочет Вам написать, - но я думаю, Вы ему не верьте! О нем тоже расскажу. ${ }^{86}$ Вобще рассказов будет много, пожалуй, гораздо больше, чем в прошлом году, и я даже понимаю, почему: литературной жизни стало больше, а политический горизонт, хотя и мрачен, но совершенно ясен. Нельзя сказать, чтоб я удачно выразилась, но Вы понимаете, конечно, что я хочу сказать.

Да, Париж - чудесен, и весна здесь особенная в этом году. Жаль будет все это покидать, если придется. Март был так тепел, что можно было выходить в платье, а сейчас - обычные апрельские дожди и запоздалые холода. Но деревья уже зеленые. С моей вышки видно небо, такое особенное тоже в Париже, а солнце бывает только утром рано. Как я буду рада повидать Ваш д о м, какой Вы молодец, что так чудно смогли устроиться. Не думайте слишком много о том, что будет, когда начнется атомный период борьбы с б-ками. Зато, если уцелеем, будет не плохо, ведь правда? Читали ли Вы в Новом Журнале Мориса Шаблэ ${ }^{87}$ Я недавно провела с ним /и его женой/ целый вечер. Об этом тоже подробно расскажу. Он на меня произвел страшное впечатление. Вчера я получила толстую и убористую программу новой полит. партии: Национально-трудовой союз /солидаристы/. Это - наиболее сильная сейчас организация из новых. Им, вероятно, будет принад-

86 Berberova found it difficult to give Georgij Ivanov (1894-1958), the prominent Paris poet of "brilliant despair," the recognition he deserved. See Kursiv moj, $531 \mathrm{ff}$.

87 Moris Šable (sic, M.L.): "V dome predvaritel'nogo zaključenija NKVD," Novyj Žurnal 16-17 (1947). 
лежать будущее - и значит, и наше с Вами. ${ }^{88}$ Я в Рус. Мысли не пишу почти, потому что они там не платят и ужасную разводят пошлость. Мне бы хотелось писать много и совсем по новому, но негде... пока. Посмотрим, что будет дальше. Роман движется. Если Вам не будет скучно, я Вам прочту первую главу. Думаю засесть очень на Хеммаре. Но трудно писать: передо мной стоит один капитальный вопрос, неразрешимый для меня: если я пишу по русски, то, собственно, надо для русских писать одно. Но так как я переведу его по франц. и он выйдет, возможно, только по франц., то надо писать несколько иначе. Это называется сидеть между двумя стульями. Тем не менее, хотя бы отчасти, разрешаю вопрос этот так: писать все-таки русский роман, а если он понравится французам больше, чем русским, то что же делать! Все это очень сложно и конечно - не весело.

Жму Вашу руку. Думаю о Вас очень дружески и радуюсь встрече. Здесь появился один человек, отчасти Вас мне напоминающий - ему 33 года, он из Риги. Чем то неуловимым. Внутренне, конечно.

НБерберова

88 NTS later became a leading émigré organization, responsible especially for the journals Grani and Posev. 
Дорогой Сергей Александрович,

после моего долгого молчания - два слова, чтобы во-первых поблагодарить Вас и за письмо Ваше, и за открытку к Пасхе. Во вторых, чтобы сказать, что я сидела в Париже безвыездно, ожидая шведскую визу со дня на день. Теперь она получена (вчера) и я еду в последних числах мая в Стокгольм. Я дам Вам знать сейчас же, как приеду. Буду, вероятно, в Дротнингхольме. Очень устала и замучилась порядком. Буду страшно рада видеть Вас. Расскажу Вам тысячу вещей. Привезу франц. «Чайковского«. Пока - до свидания, жму Вашу руку.

НБерберова 
9 сент. 1948

Дорогой Сергей Александрович,

получили ли Вы мою открытку, посланную с юга Франции? Ах, как там было хорошо! Как бы Вам понравилось! Провела я там две недели, ела фрукты, грелась на солнце, гуляла по берегу, смотрела на красивых и богатых девочек и мальчиков, писала - словом мне там было райски чудно, и только теперь я могу сказать, что лето для меня кончилось.

Вот уже три дня как я в Париже, занимаюсь писанием писем и живу, как проклятое инкогнито. Обрела свою комнату, по которой ужасно соскучилась /в этом мы друг друга понимаем/, обрела книги, бумаги, какие то предметы, милые сердцу. В книжной лавке еще не была и потому Вам еще ничего не послала. Не думайте, что повинна в растрате вверенных мне капиталов. Скоро пошлю Вам, что обещала.

Париж чуден, как Днепр при тихой погоде ${ }^{89}$ Рядом со мной собирается заседать ОНУ. ${ }^{90}$ Расскажу Вам по этому поводу смешное:

Однажды некий автор, который наименовал себя Колосовский-Пушкин /так как в предисловии он пояснял, что в него вселилась душа Пушкина/ прислал мне свою поэму /изданную за собственный счет/. ${ }^{91}$ Она называлась «Ону«. Это значило вот что: есть он, она, оно. Колосовский же придумал, что есть еще некое «ону«. Теперь Вы понимаете, каково мне слышать, что от заседаний этого «ОНУ« зависит будущее нашей планеты!!! «ОНУ« Колосовского было мохнато, черно и страшно, ону преследовало его повсюду... Здесь ону собирается заседать в Палэ де Шайо, которое в двух шагах от меня - на пляс дю Трокадеро. Да, вот какая неожиданность!

От Вас я думала найти письмо в Париже. Здоровы ли Вы? Или уже забыли меня? Как Ваши дела и работа? Как Стокгольм и милый мост, который висит у Вас в окне ${ }^{92}$

Я на юге написала такие стихи /которые можно читать, как комические а можно и как трагические/: /читать сильно нараспев/

89 Allusion to Nikolaj Gogol"s lyrical refrain in the Ukrainian story "Strašnaja mest": "Čuden Dnepr pri tichoj pogode."

$90 \quad \mathrm{ONU}=$ Organisation des Nations Unies, the French UN office.

91 Viktor Kolosovskij-Puškin enjoyed a solid reputation as a graphomaniac. Vladislav Chodasevič, Berberova's first husband, was at one time interested in him.

92 Rittenberg had a view of the beautiful Västerbron (West Bridge), which was built in 1934 to join the two Stockholm districts of Kungsholmen (where he himself was living) and Södermalm. 
«Она стояла у состава,

Глядела в даль в вечерний час.

Души больной лилась отрава,

Блистала из лазурных глаз.

Bce, все, что сердцу было мило,

Далеко поезд уносил.

Она ждала, она молила,

Но слов он не произносил...«

Так пела горничная Маша

Стирая некогда белье.

Так началась разлука наша:

Твое страданье и мое.

Черкните мне несколько строк, а то я думаю, что с Вами что нибудь стряслось. Жму Вашу руку. 
N. BERBEROVA

9 bis, Rue de Magdebourg - Paris 16e

Klé. 33-81

15 октября 1948

Дорогой Сергей Александрович,

виновата. Но заслуживаю снисхождения. Сегодня отсылаю Вам книги. Верите ли: не было минуты не только написать Вам, но даже сходить в книжный магазин и купить, что нужно. Я теперь от 2 до семи ежедневно работаю для заработка, иначе прожить невозможно, и оттого вся жизнь стала вдруг страшно тесной: времени ни на что не хватает. Утром пишу - когда душа спокойна, а спокойна она не всегда. Несомненно, мы идем к войне, а Франция идет к гражданской войне. Дело очень плохо обстоит здесь с интеллигентным трудом: издательства прогорают, люди сидят без работы «небст фрау унд кинд«. ${ }^{33}$ Художники делаются «маршан форэн «, ${ }^{94}$ а писатели - полотерами.

Книги я Вам послала три: «Эстафету«, сборник стихов, в котором многое так себе, но который Вам, как поэтолюбу, необходимо иметь. Там ужасное количество ужасных стихов, но попадаются и превосходные. «Нас« там нет. ${ }^{95}$ В «Эстафету« вложила Вам рецензию на нее Тхоржевского, которого Вы любите. ${ }^{96}$ Затем я купила Вам стихи Бунина, толстую книгу. Вы его любите, как поэта, и это Вас несомненно обрадует - так я рассудила, если ошиблась - простите. Кроме этого посланы «Александрийские песни «. ${ }^{97}$ Истратила за две книги 1 дол. - то есть половину капиталов, мне доверенных. Выйдет в этом году книга стихов Иванова, книга Смоленского. Значит, в резерве у меня есть деньги. Но Вы, очень Вас прошу, об этом не думайте, и если что нужно, напишите - я вышлю, и из Ваших; и из своих заплачу. Мне нравится, что у нас такие сложные денежные отношения - в пределе 20 крон.

Я так рада, что у Вас все устроилось с лекциями, что Вы оценены, как должно, и работаете. Вы не знаете, какое это счастье жить так, как Вы

93 Nebst Frau und Kind (German) = beside mother and child.

94 Marchands forains $($ French $)=$ peddlers.

95 Estafeta. Sbornik stichov russkich zarubežnych poètov, Paris-New York 1948. Ed. Irina Jassen, Vadim Andreev and Jurij Terapiano.

96 Ivan Tchorževskij (1878-1951), émigré poet, translator and literary scholar.

97 Michail Kuzmin's Aleksandrijskie pesni appeared in book form in Petrograd in 1918. 
живете. Правда, Париж прекрасен и так духовно богат и питателен, но есть что то прямо жуткое в воздухе здесь: в двух шагах от меня заседает ОНУ, забастовки, бедность, подземные толчки, быстротечность времени...

Была в театре, на чудном спектакле: из Венеции приехала итальянская труппа, давала «Эдипа царя«. Верите ли, театр плакал, хотя что он Гекубе ${ }^{98}$ и что она ему? И я чувствовала, как мороз по коже бежит у меня от Софокла, и вообще ничего нет лучшего, как Греция. Читаю сейчас «Банкет Платона. ${ }^{99}$ Читали ли Вы его? Умоляю Вас, немедленно достаньте и прочтите. Боже, как это прекрасно.

Представьте, о Реми де Гурмоне ${ }^{100}$ : моя подруга /француженка/, женщина очень умная и со вкусом, его страшно любит. Взялась я его читать и не смогла. До того он «красив«, искусственен и изыскан. Так и оставила. Но Вам это, конечно, дольно нравиться: Вы ведь француз. И воображаю, как Вы им наслаждаетесь! Прочтите, если можете достать, его переписку с «амазонкой«, Наталией Барнет /так кажется/, англичанкой, поэтессой, красавицей, которую он любил. ${ }^{101}$ Присмановой ${ }^{102}$ книгу /и Раевского $/{ }^{103}$ вышлю, как только увижусь с обоими. До сих пор не видала их и книгу Булич не передала.

Если я молчу, то не думайте, что хладею к нашей дружбе. Жизнь очень трудная и очень прошу Вас помнить, что я Вас ценю чрезвычайно. Жму Вашу руку.

НБерберова

98 Berberova is alluding to Hamlet's famous words in the second act of Shakespeare's play: "What's Hecuba to him or he to Hecuba,/ That he should weep for her?"

99 Platon's Symposium is usually called Pir in Russian.

100 Rémy de Gourmont (1858-1915), prominent French Symbolist.

101 Lettres intimes à l'Amazone, de Gourmont and Natalie Clifford Barney's (1876-1972) correspondence, appeared in 1919. When only twelve years old, the poet Clifford Barney reportedly realized that she was a lesbian.

102 Anna Prismanova (1892-1960), émigré poet, early pupil of Gumilev.

103 Georgij Raevskij (pseud. of Ocup, 1897-1963), émigré poet, deeply versed in German literature. 
N. BERBEROVA

9 bis, Rue de Magdebourg - Paris 16e

Klé. 33-81

17 ноября 1948

Дорогой Сергей Александрович,

сегодня получила Ваше письмо и сегодня отвечаю. Минуты не было все это время, а между тем было что писать Вам: ведь я видела «Лёнечку.$^{104}$ Он теперь уже с Вами и Вы знаете об этом. Он оказался другом детства жены Смоленского, и я встретилась с ним у Смоленских. Я даже дала ему мой номер телефона, чтобы он /если у него будет время/ позвонил, но он не позвонил, и я встретилась с ним вторично в книжном магазине «Возрождения«. Не знаю, понравилась ли я ему, но мне он не очень понравился. Правда, он все время молчал, видимо слушая Париж и нас грешных. Написал он и корреспонденцию в... Русских Новостях. Но т.к. он Ваш большой друг, то я была с ним очень мила и ничего неприятного ему не сказала. Ах, зачем он, а не Вы был здесь... Но настанет день, и это будете Вы.

Сперва - о себе. Да, милый Сергей Александрович, теперь мне все ясно: мы погибнем все от Китая. Не смейтесь, это вовсе не смешно. Мне всегда было страшно думать, что Европа гибнет от России, это было как то невероятно, как то не того... Теперь мне ясно, что все кончится, потому что будет нашествие Азии. Когда оно будет - неизвестно, конечно, может быть через десять лет. Но это будет. И так кончится в с е. И в Америке может быть раньше, чем в Европе. И тут уже не поможет ни смерть Сталина, ни интервенция... Если в течение ближайшей недели не будет брошена атомная бомба на наступающую армию Мао Цзэдуна, то мы погибнем. Это вопрос времени.

Очень мало, кто отдает себе в этом отчет, но некоторые все же отдают, те, которые ничего сделать не могут. А те, кто мог бы что либо сделать - окаменели. От глупости? От усталости? Не знаю, но дух борьбы от них отлетел, дух сопротивления, дух прозорливости. Что Вы думаете об этом? Мне немножко страшно. А Вам?

104 The writer Leonid Rževskij (pseud. of Leonid Suraževskij, 1905-1986), member of the second émigré generation, lecturer at the Slavic Department of Lund University 1953-1963, subsequently a professor of Slavic Studies at the University of Oklahoma and New York University. 
Жизнь моя проходит так: ежедневно от 2 до 7 я работаю в кутюрном заведении, работаю с удовольствием, так как это дает мне возможность жить и быть независимой. Значит эти часы выпадают из жизни. Утром пишу роман, пишу медленно и не спешу. Кроме того, на меня навалилась «Русская Мысль«. Предложили писать там около 350 строк за неделю /за что фикс замесячно/, а это не мало. Я там «редактирую« стихотворный отдел, т.е. просовываю стихи, по одному в неделю. Пока - Ахматова и Гиппиус, но будут и современники. Кроме того, ищу стихов /как бы тоже «редактирую«/ для Нового Журнала в Нью-Йорке. Кроме того, пишу критику в «Р. М.« Затем - корреспонденция. Собственные дела. Сборник «Власть народу«/респ. демокр. партии/ - тоже материал надо давать. Платят всюду мало, требуют много. Совершенно нет времени мечтать, фланировать, читать романы, есть конфеты, смотреться в зеркало и пр. Это отложим до будущей жизни.

Кроме всего этого наклевывается какой-то журнал /ежемесячный, издание «Возрождения«, редакция Тхоржевского/. Там можно тоже печататься и даже принимать участие в редактировании. ${ }^{105}$ Но время никак не хочет удлинниться, даже на чуточку. Планы мои: в феврале ехать на 10 дней в Германию, прочесть три доклада /в лагерях ди-пи, для дипийной элиты, каковая там оказалась/. ${ }^{106}$ Доклады такие: $1 /$ эмигрантская литература за 25 лет, 2/ Владислав Ходасевич - жизнь и поэзия, $3 /$ собственные сочинения и стихи парижских поэтов. Весной - в Англию на месяц. Все это было бы невозможно сделать на литературный заработок, а потому я радуюсь все время, что есть и другой, рукомесло уважаемое и кормящее.

Теперь скоренько два слова об Эстафете: Вы правы во всем. ${ }^{107}$ Перевод Богаевского - просто хамство! Ничего общего с Рильке. ${ }^{108}$ Раевский и в жизни так же становится сладок и «сенилен«. Скоро будет напоминать Богдановича, автора «Душеньки«. ${ }^{109}$ Оцуп невозможен, просто «ридикюль «, ${ }^{110}$ как говорят французы. ${ }^{111}$ А жаль, я его любила и всегда

105 Vozroždenie began publication in 1949, first under the editorship of Ivan Tchorževskij. It existed until 1974.

106 "Displaced person camps" were established in Germany, Austria and Italy for refugees from Eastern Europe and former nazi prisoners.

107 See note 95 to Berberova's letter of 15 October 1948.

108 M. Bogaevskij had translated Rilke's poem "Letzter Abend."

109 Ippolit Bogdanovič (1743/1744-1803), whose jocular, ironic poem “Dušen'ka" (1778) is in the form of a folktale.

110 Ridicule $($ French $)=$ ridiculous.

111 Nikolaj Ocup (1894-1958), émigré poet and publisher, once Gumilev’s friend. See Kursiv moj, 238-239. 
хвалила. Что Вы скажете о Набокове-Сирине? Он блестящ по моему. Терапиано вырождается на глазах у изумленного читателя.

Хочу Вам послать на память записанное стихотворение Г. Иванова, одно из последних. Спрячьте его подальше, никому не показывайте. Это только для Вас:

Судьба одних была странна.

Судьба других была блестяща.

И осеняла всех одна

России .... чаша.

Но император сходит с трона,

Всему простив, со всем простившеись,

И падает его корона

В грязь революции скатившись.

О неврастеник с задом женским,

Позор и вспоминать о нем!

В России он звался Керенским,

Паяц с ораторским огнем.

Мир управляется богами,

Не вшивым пролетариатом.

Блеснет над русскими снегами

Богами расщепленный атом.

Эти стихи - ужасны, почти гнусны, но что то в них есть задевающее и замечательное. Что Вы думаете?

«Гамлета« не видела еще. Хочу пойти, чтобы послушать, как англичане читают шекспировы стихи - никогда не слышала. Завидую, что увидите Софокла. Я его страстно люблю. Плакала, когда смотрела «Эдипа Царя« по-итальянски /!/ почти ничего не понимая. Труппа приезжала. Реми-де-Гурмона может быть и полюбила бы, да нет времени для него - уж очень Вы о нем хорошо пишете. О романе Одоевцевой мнения не имею, т.к. его не читала и вероятно не прочту: обложка с рвущейся бомбой и кровью мне внушает некоторые опасения. ${ }^{12}$

Стихи Вам посылаю. Те ли это? Я уже забыла, какие Вам дала.

112 Irina Odoevceva (1895-1990), Ostav'nadeždu navsegda, Paris 1948. 
У меня для Вас есть «Четки« Ахматовой. ${ }^{113}$ Если у Вас есть, напишите мне, тогда будет что нибудь другое. Эти «Четки« принадлежали моей покойной подруге и хранились у меня, как реликвия. У меня есть и свой экземпляр. Т.к. время реликвий проходит и вообще хранить что-либо и не давать тому, у кого нет, есть поступок аморальный, то я решила Вам эти «Четки« послать /если у Вас их нет/. Милый Сергей Александрович, спасибо еще раз за Ваше милое и такое остроумное письмо. Сейчас перечитала и предыдущее. Там Вы писали об изысканности французов. Да, особенно она стала пропадать в XX веке. Прочтите Montherlant, Giono, ${ }^{114}$ Malraux ${ }^{115}$ - там этого нет, но в Гурмоне она была. Франц. изысканность мне претит больше немецк., а англ. я даже люблю (Уайльд).

Жму Вашу руку. Скоро Lucia. ${ }^{116}$

НБерберова

113 See Berberova's letter of 30 July 1947.

114 Jean Giono (1895-1970), French author whose novels are mostly set in the Provence region.

115 André Malraux (1901-1976), French novelist and art theorist, later Minister of Cultural Affairs.

116 St. Lucia is a festival of light celebrated in Sweden that coincides with the day of the Sicilian saint on 13 December. Berberova is reminding Rittenberg that they met two years ago in connection with the Lucia celebration in 1946. 
Дорогой Сергей Александрович,

Поздравляю Вас с наступающими праздниками и желаю в Новом Году всяческих радостей и поменьше неприятностей планетарного масштаба. Посылаю Вам сегодня «Четки« к Рождеству, хотя Вы и не ответили на два раза поставленный мною вопрос: хотите ли Вы эту книжку? Имейте в виду, милый друг, что у меня еще доллар Ваших денег, который я не знаю, как употребить. Кроме того - опять буду Вашей должницей, так как попрошу Вас, как и в прошлом году, послать Грете Герелль нечто похожее на прошлогодний подарок, но конечно, если можно - не совсем то же самое. Елку с грибом или с томтегеббе /это было бы лучше/, крон за десять, если это Вам не трудно. Таким образом у меня образуется капитал - около 800 франков /вместе с долларом/ - на эти деньги можно купить много чего. Обдумайте и сообщите. Прилагаемую открытку приложите к елке Грете, пожалуйста... Да, я думаю, что можно было бы даже сделать так: томтегеббе $\mathrm{e}^{117}$ купить в ЕПА ${ }^{118}$ и приложить к елке - томтегеббе очень необходим в таких случаях. ${ }^{\mathrm{X}}$ Простите Христа ради за беспокойство, но я надеюсь, что если Вам что либо понадобится в Париже, Вы не сумневаясь ни минуты об том мне отпишете.

Недавно вспоминала Вас по следующему поводу: мне попалась французская книжка автора, никогда мною не читанного и имени которого я не знала: Жан Лоррэн, «Мосье де Бугрелон «. ${ }^{119}$ Лоррэн - современник Лоти ${ }^{120}$ и Ренье. ${ }^{121}$ Книжка оказалась замечательной и я думала: как бы она Вам понравилась!! Вообразите: чудный, изысканный, в лучшем смысле слова, язык, содержание - бредовое, необычайное, анализ и построение - умное и с таким вкусом, что просто рот разинешь... Если Вы можете в библиотеке где-нибудь в Стокгольме достать эту повесть, то прочтите непременно. Она не может Вас не восхитить. Как это я раньше про такого писателя не слышала? А Вы? И до чего Франция богата такими открытиями.

117 "Tomtegubbe" (Swedish) $=$ a little elf or gnome figurine associated with Christmas, often used as a tree decoration.

118 EPA, a discount department store in Stockholm.

119 Jean Lorrain, pseud. of P.A.M. Duval (1855-1906), creator of the eponymous dandy hero of Monsieur de Bougrelon.

120 Pierre Loti (pseud. of Julien Viaud, 1850-1923), French writer of exotic novels often set in the Orient.

121 Henri de Régnier (1864-1936), French Symbolist who was especially influenced by Stéphane Mallarmé. 
На сегодня довольно. И письмо будет коротким. Решила по Вашему совету перечитать Реми де Гурмона. Сейчас нет времени, но весной или летом - непременно. Перечитала еще раз Ваше последнее письмо. Неужели Вы не почувствовали в стихах Иванова ч т о-т о? Черносотенное и талантливое, как он сам. Получили ли посланную мною «Народную Правду«? Что думаете о об этом демократическом /!/ органе? Это теперь - крайне-левая сторона нашей эмиграции. ${ }^{122}$

Жму Вашу руку, желаю много приятных вещей, веселых праздников. Спасибо заранее за исполнение моей просьбы.

НБерберова

x Его качество и цена не играет роли - важна идея, символ.

Адрес: Fröken G. Gerell, 32 Gamla Brogatan

122 Narodnaja pravda , Russian Populist (Narodnik) journal. Sixteen issues were published in Paris between 1948 and 1950. Another two issues appeared in the United States. 
N. BERBEROVA

9 bis, Rue de Magdebourg - Paris 16e

Klé. 33-81

14 января 1949

Дорогой Сергей Александрович,

Очень, очень, очень тронута была Вашей посылкой. Представьте себе: кофе оказалось настоящей радостью, потому что у нас тут какая то заминка, месяц уже не выдавали и собираются выдать 125 грамм на человека!!! Так что я за Ваше здоровье выпила и пью. Что до молока, то это тоже было приятно, и апельсин-мармелад господина Финдус. Сахар - лишнее. Нам его выдают 1 кило в месяц и мне хватает вполне, а Вы себя лишили. Милый Сергей Александрович, ужасно этот милый жест Ваш меня тронул. Спасибо. Однако должна сказать, что это баловство, потому что /кроме Финдуса/ ей Богу можно здесь достать... в крайней мере птичье молоко.

Я пошлю Вам «Новый Журнал«, не потому что там моя повесть напечатана, ${ }^{123}$ а потому что что же деньгам Вашим лежать? И наверное есть там интересное для Вас. Это случится через неделю, когда он придет в Париж. Думаю, и журнал Тхоржевского пришлю, потому что он страшно дешев. И там есть Иванов. Вообще же, как говорили в старину: русская литература в параличе. Темперамент уходит на политику. Вчера приехал сюда Кравченко. ${ }^{124}$ Я буду на его процессе. И Вам напишу.

Мне неизвестно, читаете ли Вы регулярно «Русскую мысль«. Потом я посылаю Вам вырезку, которая может быть Вам будет любопытна. $\mathrm{Ax}$, как бежит время! Столько всего кругом, и ничего то успеть нельзя: прочесть, узнать, написать...

Я погрузилась в Шатобриана. 8 томов «Мемуаров«/замогильных/ получила в подарок на Елку и теперь читаю. Очень хорошо. Это пища первого сорта. Любите ли Вы их? Должна сказать, что Шатобриан вероятно был неприятный господин, но его писания - целый мир, и мир мне драгоценный. Пожалуй, он мне столь же дорог, как и Стендаль. А у нас не было Шатобриана. И это очень грустно. ${ }^{125}$

123 "Plač."

124 Viktor Kravčenko (1905-1966). See note 128 to Berberova's letter of 18 March 1949.

125 François-René Chateaubriand, Mémoires d'outre-tombe, Paris 1848, published posthumously. 
О Жироду ${ }^{126}$ с Вами согласна. Словечка в простоте он сказать не умел и не хотел. Он лег, простите, навозом, для современной французской литературы. Но французам этого сказать нельзя, они его очень ценят. Если Вам нравится Монтерлан, то я вышлю Вам его две $з$ а м е ч ат е л ь н ы е драмы. Он личность очень исключительная, и едва ли не /как фигура/ самая замечательная из современных французов. Был ведь почти что за немцев, потом замкнулся в гордом одиночестве. Сам - патологически одинокий и сексуально бессильный человек, твердивший всю жизнь о величии силы, спорта, мускулов и пр. Ненавистник женщин. Впрочем - все это гораздо сложнее, чем выходит в моем кратком письме.

Пока все. Жму Вашу руку и благодарю еще раз за Ваше такое мне драгоценное внимание.

НБерберова

Сейчас получила Ваше письмо. Спасибо. Кто такой du Bos? $?^{127}$ Может быть du Bosc? Да, я буду в Париже в мае. Вы приедете???? Ахти, как интересно!

126 Jean Giraudoux (1882-1944), French writer and diplomat whose dramas are often based on the mythology of antiquity.

127 Charles de Bos (1882-1939), French essayist and critic whose interests included Russian religious philosophy. 
18 марта 1949

Дорогой Сергей Александрович,

я надеюсь, что Вы читаете «Русскую мысль«, и таким образом знаете, чем я занята. ${ }^{128}$ Я туда даю иногда до полуторы тысяч строк в неделю. Три дня, от 12-ти до 8-ми сижу в суде, потом же читаю до 10-ти отчет дома. Утром за ним приезжают. Эта работа меня очень утомляет. Кроме того, я не сразу научилась ее делать. Есть и приходящее обстоятельство: у меня нет редактора, нет советника: кроме меня и наборщика Семена - никто меня не читает, поэтому я согнулась вдвое от чувства ответственности. А как же ей не быть? Я посылаю в Нью-Йорк мой текст /«Новое русское слово《/, его перепечатывают в Сан-Франциско, Лос Анжелосе и частично во Франкфурте. Его передают через громкоговорители в трех странах /в русский час/... Это все я Вам пишу, чтобы объяснить свое молчание. Ваше письмо получила и очень Вас за него благодарю.

О процессе писать сейчас не могу. Расскажу, когда увидимся. Кроме того, я Вам пошлю книгу, которая выйдет скоро: там будет мой репортаж целиком и статья. ${ }^{129}$ А также много снимков. Я не знаю, послать ли Вам «Новый Журнал« с моей повестью /кн. XX/, ${ }^{130}$ послать ли «Новоселье« и №1 и №2 «Возрождение« /очень плохой журнал/. Ответьте мне на сей важный вопрос.

Вы спрашиваете, милый Сергей Александрович, приеду ли я в Швецию в этом году? Боюсь, что нет. Денег у меня там мало, а путешествие длинное. Зовут меня в Англию на месяц, но я боюсь соскучиться в буржуазном семействе моей двоюродной сестры, где мухи мрут от скуки над вазами с душистым горошком, где пеленки внуков, пуддинги и туманы.

Но Вы приедете в Париж, и мы с Вами пойдем гулять на Иль-СенЛуи и будем смотреть в спину Нотр Дам, что я очень люблю делать. А кроме того, еще будем делать тысячу вещей.

128 Berberova gave a running account in Russkaja mysl' of the Kravčenko case in Paris. As can be seen here, her reports spread to the Russian émigré press. Viktor Kravčenko had sued the communist newspaper L'Humanité for slander when it seriously called into question his exposure of Soviet reality in I Chose Freedom. The Personal and Political Life of a Soviet Official.

129 Delo Kravčenko. Istorija processa, Paris 1949.

130 "Plač." 
Пишу Вам это нелепое письмо, чтобы сказать, что я не забыла Вас, но собраться с мыслями не могу. А потому настоящее письмо напишу Вам через неделю.

$$
\text { Жму Вашу руку. }
$$

НБерберова

Верта ${ }^{131}$ на процессе не было. Видела Виктора Винде ${ }^{132}$ и познакомилась с Ивом Дельбаром. ${ }^{133}$

131 Alexander Werth (Vert, 1901-1969), Russian political journalist and writer, English newspaper correspondent in Moscow during the war. See also note 464 to Berberova's letter of 5 September 1969.

132 Victor Vinde (1903-1970), Swedish Social-Democratic journalist who reported on the Kravčenko trial. Berberova's contact with him was made easier by the fact that his wife Rita (Margarita) was Russian.

133 Yves Delbars (pseud. of Nikolaj Kosjakov) wrote speculatively about Stalin's Soviet Union. 
Дорогой Сергей Александрович,

очень давно не писала Вам. Последнее письмо мое было, помню, какое-то торопливое, холодное и короткое. От Вас получила к Пасхе поздравление, получила до того письмо... Вы часто вспоминаетесь мне в последнее время. Все ли у Вас благополучно?

Жизнь моя проходит в трудах. Скажу прямо: если бы труды мои оплачивались лучше, я бы, пожалуй, ничего лучшего не желала. Судите сами: утром, до 12-ти, толстую и п о т р я с а ю щ у ю книгу одного еврея-сиониста о России на французский язык. ${ }^{134}$ Работы еще на два месяца. После завтрака пишу для Русской мысли. Пишу и для Народной Правды. Встречаюсь с людьми из Народ. Правды - моими друзьями и единомышленниками. Бываю в редакции Русск. мысли, где, собственно, негласно состою пятым членом редакции. Пишу медленно и по немногу роман. Вечером - премьеры синема, иногда театр, доклады - все это для газеты, не для себя. А бывает что и для себя. Читаю очень много, иногда забросив все - целыми днями, как было с книгой Виктора Сержа «Дело Тулаева« - лучшая книга о России, которую я знаю. ${ }^{135}$

В душе равновесие и покой, очень слежу за всем, что творится в мире и вывожу некоторые оптимистические выводы, - не так, как в прошлом году. Вообще - живу страшно кипуче и на виду, и к этому уже привыкла.

Людей, в сущности, дорогих сердцу, - не много. Да и вообще людей не много. Одиночество я люблю, когда оно насыщено. Осенью выпускаю книгу - шесть повестей /по-русски/. Жду первые корректуры на этой неделе. В Америку тоже пишу. Кроме того - громадная корреспонденция - с Германией, Швецией, Америкой и пр.

Меня звали в Англию на июнь, но я не еду: работа, перевод, газета все мешает. Кроме того, Англию не люблю и не вижу необходимости уезжать из Франции. Париж так хорош, как никогда, в этом году. Меня звали Греты мои и в Швецию, на Хеммаре, но я тоже отказалась: денег

134 In 1949 Berberova published in Paris her own and Mina Journot's translation of Julij Margolin's (1900-1971) autobiographical La condition inhumaine. Cinq ans dans les camps de concentration Soviétiques.

135 See note 137 to Berberova's letter of 11 July 1949. 
в Швеции пока не много, а проезд стоит дорого. Может быть приеду в будущем году.

Здесь жизнь восстановилась как-то сразу - около Пасхи, когда отменили карточки на молоко и масло. Вдруг из всех щелей поперли веселые, сытые, довольные люди, нарядные, толстые пролетарии и буржуи всех оттенков. Гуляют, радуются, сидят в кафе, покушают всякий хлам в магазинах и смотреть на них очень приятно. А по воскресеньям улицы полны, везут детей в колясочках, все пестро, шумно и как будто беззаботно. Ах, какая чудная страна Франция!

Вспоминаю, как в прошлом году в это время я готовилась к отъезду. Впрочем, кажется, я уже была в пути. Милый, чинный Стокгольм, милый Риттенберг, с видом на Мэлар! А здесь - чего-чего нет: от выставки Мюнхенской Пинакотеки до выставки кошек и рододендронов. На Сене уже купаются.

II книжка Возрождения и III книжка кажутся мне неинтересными для посылки Вам, но «Новый Журнал« по моему /21-ая книжка/ стоит быть прочитанным. Нет ли у Вас возможности доставать его в Сток.? Странно, что Нильсон не выписывает его, посоветуйте ему. Здесь и в Америке университеты давно выписывают его. Там много, очень много новых эмигрантов теперь пишет, и статьи превосходные. Простите, что посланная 20-ая книжка была подержанная - у меня не было времени пойти в магазин и купить. Я только третьего дня купила себе экземпляр, вместо Вам присланного.

Зайцевы здесь, Иванов исчез, задолжав всем, в неизвестном направлении. Смоленского не вижу - он служит в конторе и пьет. Остальные поэты тоже в упадке, и пишут плохо. Я получила в подарок Шатобриана и теперь читаю его Замогильные записки. Каков характер, но каков и талант! Вся эпоха в этой книге.

Жму Вашу руку. 
Дорогой Сергей Александрович,

если Вы на меня махнули рукой, то жаль. Я не забываю Вас. Недавно послала Вам книгу стихов Анны Присмановой... В каком положении наши с Вами рассчеты? Я совершенно н и ч е г о уже не помню. Должна ли я Вам денег и сколько?

Лето в разгаре. Где Вы? Не уехали ли на какие нибудь блаженные острова? Я сижу в Париже сердитая и усталая. Дело в том, что я, как может быть Вам писала, занята переводом /с русского на французский/ одной, довольно замечательной, книги. Сейчас я - на половине работы. Работаю с моей сотрудницей, француженкой. Мы с ней, выходит, прикованы как каторжники к одной тачке. Или я должна буду продолжать работать в городе, или ехать с ней на юг. Мне не хочется уехать одной, хотя бы на 10 дней на океан, где живут знакомые, недалеко от Ля Рошели. Все это раньше конца июля я не решу, между тем время идет, мне бы хотелось передохнуть перед осенью.

На осень довольно много деловых планов. Во первых, «Новый Журнал« /надо Вам, все таки, подписаться на него, там все очень интересно/ будет в е р о я т н о выходить в Париже, и я сделаюсь его парижским представителем - отчасти редактором /но только отчасти, для Европы/, корректором, экспедитором и пр. и пр. Так что это займет половину моего времени. Во вторых - меня приглашают в редакторы нового иллюстрированного еженедельника - единственного в мире на русском языке. Дело выгодное, но не знаю, насколько интересное. В третьих - «Возрождение« переходит из рук Тхоржевского, которого разбил паралич и кот. был дилетантом в деле, в руки Мельгунова, со всеми вытекающими из этого последствиями. ${ }^{136}$ Там тоже буду сотрудничать. Одним словом - дела много, времени мало, от жары - лень, и настроение какое то кислое.

Сегодня выходит моя книга в ИМКА-Пресс, «Облегчение участи« /шесть повестей/. Очень этому рада, 10 лет ничего не издавала по русски. «Русская мысль« - по прежнему, ни шатко ни валко, времени отнимает порядочно. «Народную правду«/№4/ Вам вышлю на днях. Там моя статья о замечательной книге Виктора Сержа /троцкиста/ «Дело

136 Sergej Mel'gunov (1880-1956), noted historian, author of "Krasnyj terror" v Rossii (1923). 
Тулаева«. ${ }^{137}$ Она вышла по французски. Если у Вас есть возможность достать ее и прочесть - Вы получите громадное наслаждение: это лучшая книга о России, какая была до сих пор в мире.

Письмо мое какое то деловое и холодное, но это не значит, что я забыла нашу с Вами милую дружбу. Париж полон шведами, и я каждый день думаю: а где же мой дорогой швед, Сергей Александрович, почему он не едет в Париж? Как бы мы с ним здесь гуляли, и он бы таял от удовольствия при виде всякой красоты... Мои Греты звали меня в Хеммаре, но я не могу ехать без денег или почти без денег. Да и уехать отсюда на долго не смею.

Читаю Шатобриана, Замогильные записки, медленно и с упоением. А вообще с чтением плохо: почти ничего не могу себе позволить прочесть с бескорыстной целью: все - для чего-нибудь! А Вы? Что то Вы? Где то Вы? Пишите мне. Жму Вашу руку.

НБерберова

137 Berberova's review of Victor Serge's (pseud. of Viktor Kibal'čič, 1890-1947) novel was published in Narodnaja pravda 4 (1949): "Čelovek i doktrina. Po povodu knigi Viktora Serža 'L'Affaire Toulaev'., 
2 сентября 1949

Дорогой Сергей Александрович,

спасибо за письмо, которое получила, вернувшись в Париж. Сегодня посылаю Вам страницу о Ходасевиче. Спасибо за Ваши всегдашние милые слова о моих писаниях: ответственность большая, я ею как то подавлена. В «Русской мысли« я теперь более или менее делаю, что хочу, но это не так просто /перед самой собой тоже/. Надо чтобы было «популярно«, т.е. чтобы меня понимало как можно большее количество людей, иногда малограмотных, писать надо в газете не для элиты. Значит, надо до известной степени снижаться, но снижаться я не хочу. Вот и нащупываю среднюю линию. Надо Вам сказать, что Ивелич - тоже я, и И-ч, и И... Так что сами понимаете!

В критике здешней я отчасти делаю погоду теперь, когда Адамович сходит на нет - качественно и количественно, ибо у них страшно падает тираж и они видимо скоро закроются. Сегодня с трудом написала статью о Гете, к юбилею. Встаньте на мое место и не судите меня строго. На 200 строках надо сказать такое, чтобы в с е м было интересно. Ужасное положение.

Книгу мою Вам вышлю, конечно. ${ }^{138}$ Хотите написать о ней критику? Только не дружественную, а настоящую? Это я говорю совершенно серьезно. Вы меня знаете, и я буду рада поместить ее в «Рус. Мысли« - под какой угодно подписью. У нас нет никого, кто бы мог написать о ней. Подумайте! Вы даже можете послать статью прямо в редакцию, я предупрежу. А то напишет Зеелер... ${ }^{139}$

Пожалуйста, узнайте, что это за Попова обо мне справлялась? Я вероятно знала ее под девичьей фамилией и «Попова« мне ничего не говорит. Что она написала? Когда и где?

Я была на океане, в чудном месте, пустынном, диком, грозном и величественном. Ездила на четыре дня в лагерь русских скаутов, видела 300 девочек и мальчиков. 50 из них /от 15 до 20 лет/ меня не отпустили и заставили четыре вечера под ряд рассказывать им о русской литературе, Швеции, читать свои рассказы из книги и пр. Вообразите широкий берег океана, дюны, луну, шелест волн, и я с фонариком и

138 Berberova's Oblegčenie učasti. Šest' povestej, Paris 1949. In Rittenberg's archive there is a copy with the dedication "Dorogomu drugu, Sergeju Aleksandroviču, na pamjat' o družbe. N. Berberova. Pariž 10.IX.49".

139 Vladimir Zeeler (1874-1954), politician, journalist, member of the Russkaja mysl' editorial board. 
книгой, а вокруг - 50 слушателей, из которых многие едва понимают русский язык. Оттуда поехала в Тулузу, через Бордо. В Бордо очень понравилось, пахло дальним странствием через океан, а Тулуза город грязный и скучный. Там базилика замечательная, с черепом Фомы Аквината и мощами апостолов, но очень дурно пахло. Кроме того, там у меня друзья: знаток яблок, груш, вишен, абрикосов, персиков, роз, винограда и пр., ученый человек В.А. Евреинов, с которым когда то мы познакомились так: он что-то прочитав мое, вдруг прислал мне в подарок ящик персиков, каждый персик с фунт. ${ }^{140}$ Вообразите, какой приятный сюрприз!

Перечитала сейчас Ваши последние три письма. Чувствую, что Вам не очень хорошо по душе. А почему? Лето это было для Вас невеселым. Чувствую, что что-то не так, юмору меньше и как будто что-то болит... Что именно? А как работа? Как одиночество? Не задумал ли барин жениться? Ах, дорогой Сергей Александрович, как я была бы рада увидеть Вас и развлечь Вас в Париже! Только на русскую литературу здесь не очень рассчитывайте /и Нильсона предупредите/: кто еще не спился, сопьется в этом году. Остальные постепенно меняют профессию.

Итак, новый год начинается. Я, как еврей, считаю, что новый год - с сентября. Желаю Вам легкости и всяческих приятностей - по возможности не дорогих! Пойдите в Тиволи, покатайтесь с гор. Помните, как Вы боялись, что я Вас заставлю кататься со мной с гор? Ужасно жаль, что я не заставила.

Жму Вашу руку.

НБерберова

140 Vladimir Evreinov (1887-1967), agronomist and pedagogue. 
Дорогой Сергей Александрович,

вчера получил Вашу рецензию и постаралась прочесть ее незаинтересованными глазами. Как тонко, как умно Вы разобрали меня! ${ }^{141} \mathrm{O}$ Чичикове, представьте себе, сказал мне когда то Ходасевич - это был последний рассказ, который он прочел перед смертью. И вообще все было такого «высокого полета«! И вчера же в Русской Мысли появилась рецензия Шика, человека столичного, культурного, но насколько же она была н и ж е Вашей. ${ }^{142}$ Посылаю Вам ее. Ваша статья навела меня на всякие мысли: Вам необходимо стремиться в Париж. Вы можете здесь писать и печататься. Таких людей осталось уже немного.

Вчера же я переслала в «Возрождение« Вашу статью. ${ }^{143}$ Может быть Вы не будете довольны, но они ищут к р и т и к а, и Вы могли бы быть им полезны. Я на ближайших днях пойду к Мельгунову /редактору/ и поговорю с ним - не о рецензии на мою книгу /тут настаивать мне не очень удобно/, но вообще о Вас. Думаю, что и рецензию они напечатают, а кроме того, хочу, чтобы он обратился к Вам за новой работой. Они платят - мало, но все таки это могло бы положить начало фонду денег для Вас в Париже. Как это было бы хорошо! Что Вы об этом думаете?

Я не вижу будущего в Стокгольме, где Вы постепенно отдалитесь от многого, и это жаль. Конечно, здесь трудно, но не безнадежно трудно. И постепенно, если у Вас будет желание перебраться сюда, я во многом помогу Вам. Сама я, благодаря энергии, проработав два года очень мучительно и живя бедно, сейчас достигла некоторого «благополучия«, т.е. вырабатываю жизненный минимум - литературой. Может быть, можно было бы найти Вам переводы. Сама я от них в будущем году буду отказываться, т.к. работы и без того много, но у меня бывают предложения. «Возрождение« тоже могло бы помочь Вам дышать.

Это - проект и он только постепенно может осуществиться. Трудность тоже в квартире. Отели дороги. Может быть, тетушка могла бы сдать Вам комнату покойного супруга? Конечно, «стандарт« квартирный здесь гораздо ниже стокгольмского и Вы были бы не у себя. Но

141 In his review of Berberova's Oblegčenie učasti, Rittenberg wrote: "Ee bol'še vlečet mir čelovečeskich otnošenij, žestokij i polnyj protivorečij, i, na ètom fone, vnutrennij konflikt odinokoj čelovečeskoj duši."

142 Aleksandr Šik's (1887-1968) review of Oblegčenie učasti in Russkaja mysl', 4 October 1949.

143 The review was finally published in Novyj Žurnal 23 (1949). Rittenberg signed it "Ėrg," a pseudonym he had also used in Žurnal Sodružestva. 
П а р и ж, как таковой, окупит эту неприятность. Есть тоже «Институт Восточных Языков«, где директор - Пьер Паскаль, профессор и мой добрый знакомый. ${ }^{144}$ Если у Вас есть страж и дипломы то м.б. можно попытаться стать там лектором? Все это мелькает у меня в голове со вчерашнего дня и я, конечно, жду Вашего ответа, чтобы очень постепенно начать работать в желаемом направлении.

Я живу хорошо, но бурно в смысле работы. «Новый Журнал« будет отныне печататься в Париже/дешевле/ и я здесь становлюсь их представителем - печатать, корректировать, рассылать, рассчитываться с типографией и сотрудниками, с книжными магазинами, следить за всем и пр. Злые языки говорят, что я произведена в редакторы, но это неправда, конечно. Это мне дает половину денег нужных на прожитие. Остальное дает «Русск. Мысль«. «Возрождение« и «Нар. Правда« тоже существуют /вторая не платит/, кроме того медленно двигается роман. Сами судите, что за жизнь!

Жму руку. Еще раз спасибо.

НБерберова

144 The prominent French Slavist Pierre Pascal (1890-1983), author of both historical and literary studies. 
10 ноября 1949

Дорогой Сергей Александрович!

Сегодня - Ваше письмо. На прошлое не ответила. Не знаю, чем кончилась Ваша переписка с Мельгуновым, предлагал ли он Вам работу в «Возрождении«? Со своей стороны скажу, что всякая Ваша рецензия об интересной русской или иностранной книге будет напечатана «Новым Журналом« - если Вы ее напишете. Не вышла ли у Вас книга Шпербера «И куст стал пеплом«/т.е. купина неопалимая/? ${ }^{145}$ О ней Вы могли бы написать. Подумайте! Кстати /они одного духа/ и о «Тулаеве«. «Нов. Журн.« не только платит , но Вы бы имели даром книжку. Я бы на Вашем месте регулярно писала туда - три-четыре рецензии в год на любопытные иностранные книги о России. Вы можете написать о Марголине, кот. выходит через месяц и кот. я Вам пришлю. ${ }^{146}$ Если да, то я Карповича сейчас же предупрежду, чтобы это осталось за Вами. ${ }^{147}$ Критиков нет совсем и Вы были бы дороги. Об Оруэлле была рецензия в «Соц. Вестнике«, ${ }^{148}$ о «Тулаеве« - в «Нар. Правде,${ }^{149}$ но есть еще книги, и я их Вам буду «сигналировать«.

Пока обращаю внимание Ваше на Шпербера и Марголина.

Нов. Журнал посылаю. По моему, имеет смысл его выписывать. Это все же маркой выше «Возрождения« и политиканства меньше, и он конечно - демократичен. «Нар. Правду« посылаю в подарок. Об уплате за нее не беспокойтесь.

Я была занята это время делом приятным: приезжал из Н.-Й. Керенский ${ }^{150}$ и мы виделись много и часто. Когда то дружила я с его покойной женой, молодой, красивой австралийкой, кот. умерла в 45-ом году и с кот. он в 1938-40 г.г. часто бывал у меня. С ним я знакома с 23 года, с Берлина. Сейчас многое было о чем поговорить. Он все тот же. Горит Россией - но дела нет никакого настоящего, да и мог ли бы он что нибудь д е л а т ь? Словом, отношение мое и лирическое, и

145 Manès Sperber (1905-1984), Austrian writer, journalist and psychologist who early on broke with Communism. The original title of his autobiographical novel is Der verbrannte Dornbusch.

146 See note 134 to Berberova's letter of 23 May 1949.

147 Historian Michail Karpovič (1888-1959), editor-in-chief of Novyj Žurnal.

148 B(oris) S(apir) reviewed Orwell's 1984 in Socialističeskij vestnik 7 (1949) under the title "Sovremennaja Šigalevščina (O romane Žorža Orvila (sic, M.L.) '1984')."

149 See note 137 to Berberova's letter of 11 July 1949.

150 Aleksandr Kerenskij (1891-1970), Prime Minister in the Provisional Government in the autumn of 1917. 
критическое, и вообще довольно сложное к этому человеку, кот. и сам сложный. Сперва Париж его оглушил. Потом - показался пустыней - «иных уж нет, а те далече«/за 9 лет отсутствия/. ${ }^{151}$ А под конец - и уезжать не хотелось.

Сейчас мне стало свободнее: занимаюсь «Рус. Мыслью«/кот. плоха!/ , хожу в кино, пишу о кино, пишу о книгах. Занимаюсь «Нов. Журн.«, который должен скоро выйти и я увязаю в корректурах. Корректуры пришли от Калман-Леви ${ }^{152}$ книги Марголина - тоже заполонили комнату. Словом - дело есть, но уже не так душит, как два месяца тому назад.

С поэтами плохо. Иванов находится на последней ступени падения и его никто знать не хочет. Его стихи в «Возрожд.« Вы наверное читали /кн. 5/. Они откровенны: «злощастный Сталинград« и пр. Этого люди не прощают. Смоленский становится форменным алкоголиком. Остальных не видно, не то заняты другим, не то пьют... Недавно был какой-то вечер /я не была/ - Одоевцева читала баллады 22-го года, потом выступали какие то неизвестные дамы... Словом - мрак. Я читаю медленно /вот уже 8 мес./ Шатобриана «Замогильные записки«. Боже! Как хорошо! Как упоительно умно!

\section{Привет!}

НБерберова

151 Quoted from chapter 8 of Evgenij Onegin, which itself is a quotation from the Persian poet Sadi: "Inych už net, a te daleče/ Kak Sadi nekogda skazal."

152 Calmann-Lévy, French publishing house. 
(Undated, postmarked 1 December 1949)

Дорогой Сергей Александрович,

отвечу на Ваши два последних письма подробно, а пока прошу Вас вернуть мне номер 20 Нов. Журн. - вместо него Вам будет выслан 22-ой, когда выйдет /через 2 нед./. За Нар. Правду Вы мне ничего не должны. Это подарок. Нов. Журн. стоит с пересылкой -450 фр. Значит за два номера 900. Денег не пересылайте.

Пока жму Вашу руку. До самого скорейшего письменного свидания!

НБерберова 
(Undated, December 1949)

Дорогой Сергей Александрович! Поздравляю Вас с Рождеством и Новым Годом и желаю Вам много приятностей, а нам вместе желаю увидеться. Письмо длинное и подробное напишу Вам скоро - обещаю свято. Жму Вашу руку. Дружески Ваша

НБерберова 
Дорогой Сергей Александрович,

с Новым Годом! Давно-давно не писала Вам, но не забывала Вас. Мысли мои были в Швеции часто за это время, а 24-го вечером я звонила по телефону к фру Асплунд, где были все мои друзья, Греты, чемпионы парусного спорта и профессора гимнастики... ${ }^{153}$ В минуту мне дали Дротнингхольм - прямо чудесным образом. Ах, как жаль, что это такое дорогое удовольствие и что нельзя с Вами таким же способом побеседовать!

Я обрекаю себя отныне на жизнь аскетическую и одинокую - надо писать роман во всю, без развлечений и передышек, ежедневно, иначе никак нельзя: в Нов. Журнал посылать пора, Карпович ждет, да и довольно он у меня настаивался. Сижу, значит, дома и скриплю пером. Кроме этого пишу еще для газеты - без этого не проживешь, но зато все остальное - по боку. Перевод мой книги Марголина вышел у Кальман-Леви неделю тому назад. ${ }^{154}$

Завтра или послезавтра пошлю Вам №22 Нов. Журн. Таким образом, Вы будете мне должны за две книги 900 фр., т.е. приблизительно 15 крон. Как Вы мне их переправите - мне все равно. Придумайте что-нибудь. Я думаю, можно рискнуть.

Передо мной Ваши два последних письма. В одном из них Вы пишете об антологии русской поэзии на английском языке. Да, это антология Святополк-Мирского, погибшего в конце концов в ссылке, на Камчатке или где то в этом роде. ${ }^{155}$ Но та антология, кот. была у Вас в руках видимо уже переделанная антология Мирского. ${ }^{156}$ Во всяком случае - от первого издания в ней осталось мало.

Я чувствую, что Вы не удовлетворены моими письмами о Париже и жизни здесь. Но я должна Вам сказать, дорогой Сергей Александрович, что почти никого нет вокруг меня - все до того находятся в маразме, что прямо совестно сказать! Смоленский, прозрачный и полупьяный, иногда заходит. У него гомерическая тоска и он служит бухгалтером в какой то конторе. Иванов, думаю, покончит с собой; пока держится тем, что ходит и просит по знакомым и пропивает все, как и жена его.

153 See note 20 to Berberova's letter of 20 June (1947?).

154 See note 134 to Berberova's letter of 23 May 1949.

155 Dmitrij Svjatopolk Mirskij (b. 1890) died in a concentration camp in Magadan, 6 June 1939.

156 See note 80 to Berberova's letter of 20 February 1948. 
Никто не может понять - правда ли они голодают или только делают вид; во всяком случае, они говорят все время, что ждут какие то миллионы... Присманова и Гингер ${ }^{157}$ милы на расстоянии и я их никогда не вижу. Советские люди, вроде Ладинского, Адамовича, Софиева ${ }^{158}$ ни с кем из нас не встречаются - запрещено, очевидно. Видаю Злобина, кот. /секретарь и наследник Мережковских/ распродает архивы своих патронов, что очень грустно. 50 писем Брюсова, 8 Розанова, 60 Ходасевича и пр. - все это пропадет пропадом, как и вся Россия. ${ }^{159}$

Бываю у милых мне Зайцевых, а кроме этого, по правде говоря, ни к кому не тянет. Париж дает много - и этого мне вполне хватает. Бываю в редакции Русской Мысли - по долгу службы, и в Возрождении потому что дружески отношусь к этому журналу и помогаю, чем могу. Занята была очень изданием 22-ой книжки Н. Ж., теперь кое-чему научилась и будет легче - если они будут продолжать издавать ее в Париже. Для этого - много оснований.

Хожу в кино 2-3 раза в неделю, как критик газеты. Видела много хорошего. Ходите ли Вы? Видели ли «Луизиана-стори«, ${ }^{160}$ «Пимлико«, ${ }^{161}$ «Велосипедного вора«? ${ }^{162}$ Верта не видела и о нем ничего не слышно, но Дельбар у меня на большом подозрении. Недавно был с ним конфуз - может быть умышленный...

Жму Вашу руку, милый друг.

НБерберова

157 Aleksandr Ginger (1897-1965), émigré poet, noted for his slightly archaic language.

158 Jurij (Bek-)Sofiev (1899-1975), émigré poet who later returned to the Soviet Union.

159 Vladimir Zlobin (1894-1967), poet and critic, member of the Zinaida Gippius-Dmitrij Merežkovskij inner circle, their secretary and archivist.

160 Louisiana story, 1948 American film directed by Robert Flaherty, 1948.

161 Passport to Pimlico, 1949 British comedy film starring Margaret Rutherford.

162 Ladri di biciclette, 1948 Italian neo-realist film directed by Vittorio de Sica. 
Дорогой Сергей Александрович,

Спасибо за Ваше сердечное письмо. Я каждый раз радуюсь беседе с Вами. Ах, Швеция, нет в мире лучше края... ${ }^{163}$ Но поеду ли я туда - это вопрос. Если бы было много денег, полетела бы на три недели под крылышко к Гретам. Но, посудите сами, на эти деньги можно «смотаться« в Италию. Пока ничего такого не думаю.

Здесь ряды редеют. Завтра в Америку едет Гуль /по квоте/ - для меня событие несколько грустное. ${ }^{164}$ Распадается группа «Нар. Правды«, кот. то ли будет, то ли нет; старики стареют, слабеют и выбывают из строя. Молодых нет - из новых эмигрантов едут прямым рейсом в НьюЙорк; наше поколение разлагается: «правые« от алкоголя, «левые« от левизны. Я живу совершенным анахоретом и строчу свой роман: пока есть журналы надо его печатать, может быть и издать книгой, а там видно будет - можно и другим делом заняться. В него я вкладываю в с е, что есть во мне. И Вы будете судить. ${ }^{165}$

По зрелому размышлению я думаю, что 15 крон лучше всего передать Грете Герелль. Я ей должна немножко денег, и это будет в счет моего долга. Поэтому, как только Вы сможете это сделать - пожалуйста, сделайте. Напрасно Вы обругали Газданова. А мой рассказ - в кн. 6 Возрождения, кот. я хочу Вам послать, если у Вас ее нет. ${ }^{166}$ Неужели Нильсон не выписывает наших журналов? Что за странный человек! ${ }^{167}$

О Дельбаре: в самый разгар антисоветской газетной кампании по какому то весьма справедливому поводу, среди новостей о Тито-Сталине, о Мао Цзэдуне и пр. вдруг - сенсационная статья Дельбара на первой странице Пари-Пресс /умеренная/ о новой политике Кремля: больше не будет давления внутреннего, отменяется цензура, поднимается железный занавес. Что это было? Никто не понял! Кем он был инспирирован? Вид это имело весьма странный. Ничего, конечно, не было правдой, и Дельбара на некоторое время отстранили. Вероятно, скоро все таки простят.

163 See note 31 to Berberova's letter of 30 July 1947.

164 See note 253 to Berberova's letter of 27 April 1957.

165 The novel Mys bur'.

166 The story "Iz čego delaetsja son."

167 Here there must be some sort of misunderstanding. The Russian Institute library headed by Nilsson subscribed to a number of Soviet periodicals. 
Роман Одоевцевой успеха не имел. ${ }^{168}$ Слишком много документальной литературы дла того, чтобы квази уна фантазия на сов. темы имела успех. Положение их плохо. Что до Вад. Андреева, то... пассон, как говорят французы. ${ }^{169}$ Во всяком случае, мне как то неуютно знать, что он с сов. паспортом был пущен в Америку и работает в ООН. За чей счет? В чью пользу? Явно - не в нашу пользу!

Знаете ли Вы, что Адамович и еще двое ушли из Русских Нов. Боясь репрессий нынешнего франц. министерства, не получая денег и видя, что газета идет ко дну. Таким образом, я остаюсь единственным лит. критиком в Париже, что меня совершенно не радует. Но уж какие то личности начали мне ласково улыбаться - те, что еще полгода тому назад старались не поклониться.

О люди!

Жалкий род,

достойный и слез

и

смеха!

как писал Маяковский.... ${ }^{170}$

Жму Вашу руку.

НБерберова

168 See note 112 to Berberova's letter of 17 November 1948.

169 "Let's say no more about it." Berberova could not accept the fact that her colleague Vadim Andreev (1903-1976) was amenable to cooperation with the Soviet Union.

170 Quotation from Puškin's poem "Polkovodec" (about Barclay de Tolly). 
8 февраля 1950

Дорогой Сергей Александрович,

эти дни не чувствовали ли Вы некую телепатию? Я почему то много думала о Швеции, о Вас. Когда и как увидимся? Причина косвенная была следующая: в Упсале живет некий ди-пи Графов, с женой и дочерью. Это человек, который нашел меня по газете. Он был тем, кто последним видел моих родителей перед их гибелью в осажденном Петербурге. У меня к нему теплое чувство на этом основаниии. И вот этот Графов написал мне паническое письмо: боится, что Швеция выдаст его СССР. Это финские дела на него так подействовали. ${ }^{171} \boldsymbol{Я}$ конечно сейчас же, как говорится, нажала все кнопки в Америке и думаю, ему дают визу в Нью-Йорк. В связи с этим беспокоилась и о Вас. А Вам не страшно? Или у Вас такой паспорт, что ничего с Вами сделать не могут? Но в дальнейшем всегда ли будет не с т р а ш н о?

Была и вторая причина: вообразите, разбирая старые письма я нашла одно письмо из Петербурга, двадцатых годов, где мне пишут, что «Таня Риттенберг вышла замуж за Колю Коварского. «172 Кто это такая? Ведь Ваша сестра за другим литератором. Или она развелась и вышла замуж во второй раз? ${ }^{173}$ А сообщают мне это потому, что Таня Риттенберг училась у меня в гимназии. А гимназия была Михельсон. Говорит ли это что либо Вашей памяти?

Я здесь пишу свой роман, ${ }^{174}$ мало кого вижу, все старые, скучные и печальные. Многие стремятся в Америку. Думаю, через год-два никого не останется. Но ужасно я полюбила свою комнату, свой угол. Может быть, это старость? Или просто потому, что хорошо мне тут работается? Хотелось бы мне увидеть Вас в моем кресле, под лампой... на фоне книг...

Вам из Германии должны были послать номер 6 Возрождения с моим рассказом. ${ }^{175}$ Получили ли? Это - подарок, конечно.

171 Probably an allusion to the 1948 Finno-Soviet treaty and its consequences.

172 Nikolaj Kovarskij (1904-1974), Tat'jana Rittenberg's first husband. He had various positions in the Soviet film industry, and as a literary scholar was a member of the "Young Formalists" in the 1920s.

173 This is exactly what happened. Tat'jana Rittenberg's second husband was the writer Jurij German.

174 Mys bur'.

175 "Iz čego delaetsja son." 
От Греты получила письмо. Думаю, что она не приедет в этом году в Париж - много причин на это, и странных, по нашему русскому разумению. Вероятно, будут приглашать меня летом. Но у меня денег нет в Швеции и все это далеко и дорого.

А что Вы думаете о событиях ${ }^{176}$ Как настроен Лунин? ${ }^{177}$ Почему в конце концов он вернулся из Америки? Не кажется ли Вам, что мы все целиком, со всей Европой, идем таки к решительной катастрофе? Читаю «Банкет« Платона. Ходила слушать в Сорбонну очень интересные лекции по эстетике... и другие, о Ясперсе ${ }^{178}$ и Гейдеггере. По сему Вы можете видеть, как проходит моя жизнь. В «Рус. Мысли«-кабак, безграмотность, чепуха и пошлость. Продолжаю работать, однако.

Что то весеннее сегодня в воздухе, на моем восьмом этаже. Обманчивая парижская погода. А может быть и правда? Вот бы хорошо.

Спасибо за милое Ваше поздравление к именинам.

Жму Вашу руку.

НБерберова

176 Presumably refers to incidents in Korea that would eventually lead to the outbreak of war on the peninsula.

177 Konstantin Lunin (1907-1957), Russian-Estonian physician in Stockholm, emigrated to the United States in 1949 but returned.

178 Karl Jaspers (1883-1969), German philosopher and psychiatrist. 
18 февраля 1950

Дорогой Сергей Александрович,

Ваше милое письмо получила вчера. Нет, я не собираюсь в Америку, хотя меня зовут - и даже зовут в Австралию! Досижу здесь до последнего или предпоследнего момента, который, конечно, наступит - в этом иллюзий у меня нет. Но когда? Может быть, еще немножко дадут подышать?

Посылаю Вам вырезку, кот. я для Вас сберегла, она из «Нового Русского Слова«/Нью-Йорк/. За ней следовал кусок «повести«, кот. мне показался очень скучным.

Однако, михельсоновские гимназистки оказались чрезвычайно соблазнительны для русских литераторов: Муся Алонкина была предметом влюбленности всех «Серапионовых братьев«-ей посвящен их первый сборник. Дуся Каплан замужем за М. Слонимским, ${ }^{179}$ Т. Ритт. за К. ${ }^{180}$ и за.$^{181}$ И даже в эмиграции - Нина Каплун - за поэтом Пиотровским. ${ }^{182}$ Не считая меня! Каково? Согласитесь, что это много. Да, по моему, я еще кого то забыла.

Вы пишете мне всевозможные интересные вещи. А я Вам скажу, что у Вас диапазон на французскую литературу прямо гигантский: Бенда ${ }^{183}$ ужасный прохвост, коммунист и враг Жида. А Моклер - прохвост-антисемит, коллаборант, и скрылся куда то. ${ }^{184}$ Вот так чтение!!!

Но Вы не вздумайте сердиться, дорогой Сергей Александрович. Это я от зависти. Сама ничего не читаю, ни коммунистов, ни коллаборантов, строчу роман, «Мыс Бурь«, и еще на меня навалилось: вообразите, 12 марта с Зайцевым в Брюссель, давать вечер, а 13-го читаем по французски в тамошнем ПЭН'клубе. Надо еще что то выдумать для этого самого ПЭН'клуба.

Послала я Вам свою рецензию о Г. Иванове. Он все наврал. - Вы увидите, а про Волошина я даже не знала. ${ }^{185} \mathrm{Ax}$, что за человек, этот

179 Michail Slonimskij (1897-1972), prose writer, member of the Serapion Brothers.

180 See note 172 to Berberova's letter of 8 February 1950.

181 See note 173 to Berberova's letter of 8 February 1950.

182 Vladimir Korvin-Piotrovskij (1891-1966), émigré poet, prose writer and dramatist.

183 Julien Benda (1867-1956), left-leaning French writer.

184 Camille Mauclair (1872-1945), French writer and art critic.

185 See note 195 to Berberova's letter of 4 July 1950. It is unclear what Ivanov is purported to have "cooked up" about Maks Vološin. 
Г.И.! Совершенно спился и нищий, и противный, и просто никто уже не переносит его - даже ближайшие друзья. Вы знаете, как я ценю его поэзию, но если бы Вы видели его самого! Просто несносен. В пьяном виде кричит «хейль Хитлер!«, пьет, когда нет другого питья, денатурат, и собственно - невменяем. Недавно звонил по телефону, сказал, что хочет придти ко мне в гости /был, конечно, пьян/ и представьте, я сказала, что не могу его принять, т.к. слишком занята. Это даже не очень на меня похоже.

Как я рада, что Вы заняты, работаете много и зарабатываете. Может быть, приедете весной? По поводу Гумилева я совершенно с Вами согласна, и вообще очень много согласна, и чем дальше, тем больше. Вот только о новой живописи - не совсем. Я знаю лично многих французских художников. Они мучительно ищут, ничего не делают для снобов, а тратят жизнь свою на творчество, кот. им не приносит радости - и они это видят и еще больше отчаиваются. Что до Брака, ${ }^{186}$ то он умнейший, тончайший, прелестный человек, «вией франс « ${ }^{187}-$ и больше таких не будет. Но, конечно, я предпочитаю Босха и Вермеера. А теперь прощайте. И пожалуй - надолго, потому что напишу уже после Бельгии. Слишком буду занята. Простите.

НБерберова

186 Georges Braque (1882-1963), French Cubist painter.

187 Vieille France $($ French $)=$ a person with traditional ideas. 
26 апреля 1950

Дорогой Сергей Александрович, все Ваши письма и открытку получила. Не сердитесь, что пишу кратко. Грета Герелль едет в Париж - может быть она позвонит Вам перед отъездом из Стокгольма, чтобы Вам сообщить об этом. Что касается д-ра Нильсона, то мне многое есть, что ему сказать, но я не хочу ему написать непосредственно, т. к. хочу, чтобы все наше знакомство шло через Вас. ${ }^{188}$ Поэтому передайте ему, что, как только он приедет в Париж, я буду счастлива с ним увидеться и дать ему нужные адреса, и рассказать ему очень многое, что даст ему полную картину литературы в эмиграции, кот. все больше начинает напоминать Шагреневую кожу. ${ }^{189}$ Объясните д-ру Нильсону, что я человек не узко-партийный и с удовольствием сведу его не только с друзьями, но и с инако-мыслящими. Очень нехватает Вас иногда, особенно в эти дни, когда вздумала перечитать «Портрет Дориана Грэя «190 - после 30 лет разлуки с ним. Какая гениальная книга и как мы все из нее вышли. Согласен ли Вы?

Жму Вашу руку.

НБерберова

Ваша рецензия обо мне идет (?) в ближайшей кн. Нов. Журнала. ${ }^{191}$

188 See note 26 to Berberova's letter of 16 July 1947.

189 Honoré de Balzac's Le peau de chagrin (1831) is a tale about an impoverished noble in Paris who finds a magical wild ass's skin that fulfills his wishes but also constricts and shortens his life.

190 Oscar Wilde's famous novel The Picture of Dorian Gray.

191 See note 143 to Berberova's letter of 5 October 1949. 
Дорогой Сергей Александрович,

Вы тысячу раз правы, что упрекаете меня за молчание. Много раз хотела писать Вам, но не могла: роман меня совершенно съел! Все время, все силы уходили на него, а кроме того - работа в газете, и заботы о хлебе насущном, и всякие иные дела. Я просто не могла сделать нужного усилия, да и сейчас его делаю с великим трудом.

Роман кончен, переписан. Две трети уже в Америке, а третья часть уедет на днях. Начнется он печататься со следующей книжки Нового Журнала, 24-ой /23 только что вышла/. Не могу даже сказать Вам, рада я, что дописала его, или не рада. ${ }^{192}$ Чувствую такую усталость, что едва жива, и готова, если бы была возможность, лежать целый день на кровати. Эта зима была для меня трудной - по количеству сил, кот. я затратила на работу. Надеюсь устроить будущую зиму по другому. В крайнем случае - переменю профессию на менее утомительную.

Д-р Нильсон был у меня два раза. Один раз обедал. Очень Вам благодарна, что Вы послали его ко мне, но дел у нас с ним, конечно, никаких не выйдет - я ему не нужна, как и вообще никто не нужен. Он занят своей работой, жаловался на урезывание субсидий Институту, вообще - не совсем понятно, кому все это в Швеции нужно? Флегматический его темперамент и отсутствие живого интереса к современности меня в нем очень разочаровали, он плывет по течению - это все. Конечно, есть и симпатичные черты, их Вы знаете, не хуже меня. ${ }^{193}$

Я вероятно много требую от людей. Но сейчас такое время, что трудно мириться с флегматиками, живущими, в общем, сегодняшним днем. Я думаю, что мы стоим у самого преддверия колоссальных событий. Думаете ли Вы это тоже? В Швецию меня зовут усиленно, но это совершенно невозможно: ехать на месяц слишком дорого, переехать совсем - не вижу резона. Если придется ехать отсюда, то конечно на Запад. Но я об этом думаю по прежнему очень мало и в тонах весьма расплывчатых. Хотя оттуда и зовут.

На лето у меня есть маленький план: ехать на месяц на юг. Денег мало, но меня приглашают, как «paying guest« около Канн, что меня очень

192 Mys bur'.

193 Later, on 8 and 15 January 1951, Nilsson published two articles on émigré literature in the Swedish daily Expressen that clearly seem to reflect Berberova's dark view of the situation. The titles of the articles speak for themselves: "Dying Literature" ("Döende litteratur") and "Empty Millstones" ("Kvarnstenar som mal tomt"). 
устраивает. Если удастся, то выеду после 20-го июля, с тем, чтобы вернуться после 15-го августа. А Вы?

Г. Иванов выпустил книжку стихов, кот. меня очень разочаровала: ни одного с в о е г о слова, все набрано ото всех /начиная с Надсона/. ${ }^{194}$ Пока он стихи читал вслух, были они довольно пронзительны, пока печатал в журналах - сходило с рук. А в сборнике все это оказалось салатом из давно отжившего. Жаль! На днях в Русск. Мысли будет о нем моя рецензия - уважительная, конечно. ${ }^{195}$

Я ничего не читала уже много месяцев, и вижу очень мало людей. Сотрудничаю по немногу и по американски в журналах. Был здесь фон Мореншильд - редактор «Решен Ревью« ${ }^{196}$ Буду у них сотрудничать. Все было бы ничего, если бы мы не сидели на пороховом погребе, - когда он взорвется, взлетит на воздух мир и мы вместе с ним. В этом последнем положении есть некоторое утешение. Не: «на миру и смерть красна«, а «с миром«. Этого еще нашим предкам в голову не приходило. В романе моем об этом тоже есть...

Жму Вашу руку. Верьте моим неизменным дружеским чувствам.

НБерберова

194 Semen Nadson (1862-1887), poet whose lyrics were set to music by Rachmaninov and others.

195 On 7 July Berberova published her review of Georgij Ivanov's recent poetry collection ("Portret bez schodstva. Kniga stichov G. Ivanova") in Russkaja mysl'.

196 Dimitri Sergius von Mohrenschildt (1902-2002), founder and editor-in-chief (to 1974) of The Russian Review. 
Дорогой Сергей Александрович,

Мне стыдно за молчание, и я прошу вас простить меня. Жизнь моя была очень трудной в последние шесть месяцев. Напишу Вам в нескольких строках, в чем она состояла:

До июля я писала роман, «Мыс Бурь«, который начнется печататься в ближайшем номере «Нов. Журнала«. ${ }^{197}$ Начались корейские события. Мне надо было решить, что делать дальше, в смысле материального устройства своей жизни, т.к. далее продолжаться так не могло. Или надо было найти работу здесь, постоянную и нормальную, или уезжать. На душе было тревожно и тоскливо. Париж - пуст, похож на кладбище, людей «близких« осталось очень мало, все старые. Сверстники пьют и сходят на нет... Из Нью-Йорка же звали меня, я понимала, что там я могу и работу найти, и вообще - содержание жизни, увидеть новую страну и быть, может быть, в бо́льшей гармонии с окружающим, чем здесь. В это же время я, подправив свой английский язык, держала экзамен в ООН - два языка и третий - русский - главный, т.к. я хочу попасть не в переводчики, а в «редакторы русских текстов«, а для этого у меня все данные /требуется большой литературно-журналистический стаж/. Словом, наступила осень, я не отдыхала, чувствовала себя усталой, одинокой и неприкаянной, да еще и совершенно без денег /«Русская мысль« - дает треть того, что нужно человеку самому скромному/. Видела, что геройству тоже может придти конец. Хлопотала о визе в Соед. Штаты, продавала книги, копила на билет. Наконец, наступил день, когда все решилось: была виза, и куплен билет на 4 ноября, и я уезжаю. Квартиру оставляю за собой /будет жить подруга/ и вообще у меня нет чувства, что я еду навеки - виза у меня на год. Я должна в Н.-Й. прежде всего найти заработок. Возможно, что с января попаду в $\mathrm{OOH}$, или пойду преподавать русскую литературу в университет или колледж, друзей там больше чем здесь, все устроены - люди менее «квалифицированные« чем я. Есть два заказа для американской прессы, наконец - есть деньги за «Мыс Бурь«, кот. меня там поджидают. А главное - я выйду из маразма, в кот. мы здесь - остатки русской эмиграции - пребываем. Вероятно, можно жить в Париже, в полном одиночестве и бедности, но после того, что было здесь, жить на кладбище - невозможно.

197 Mys bur' appeared in 24-27 (1950-1951). 
От всего этого я чувствую себя усталой и даже слегка замученной - заботами, тоской, безработицей /относительной/ и неизвестностью будущего. Но я одна, самостоятельна и здорова, и думаю, что не пропаду, да и язык знаю. Европа... это конечно самое страшное: оторваться навсегда невозможно, слишком больно. И милая Швеция тоже отдаляется так далеко.

Черкните мне два слова, что не се́рдитесь. Адрес мой в Н.-Й.: с/о Zetlin, 112 West 72 Str. New York 23 (N.Y.). Это - жена Мих. Ос. Цетлина, издательница Нового Журнала. ${ }^{198}$ Пробуду у нее пока не найду заработка и комнаты. Это большое счастье, что есть, где приткнуться.

Напишите мне о себе. Что Вы делаете, чем заняты, как работаете? Получили ли Вы номер 23 Нового Журнала, где напечатана рецензия ЭРГа обо мне? ${ }^{199}$ Надеюсь, что да. Если нет, то вышлю Вам сейчас же.

Из Америки напишу Вам, милый Сергей Александрович. Во всем, что происходит со мной сейчас, есть только один «луч света в темном царстве $\ll^{200}$ - это мой «Мыс Бурь«, кот. надеюсь Вы прочтете. Это - вся я, целиком. Возможно, что устрою его по американски и по французски. Буду стараться устроить и по-шведски - он очень современен. Тогда приеду в Швецию. Это будет большая мне радость. Думаю, что расстаемся с Вами не навеки. Жму Вашу руку.

НБ

198 Like her husband, the publisher Michail Cetlin (1882-1945), Mar'ja Cetlina (née Tumarkina, 1882-1976) was a poet.

199 See note 143 to Berberova's letter of 5 October 1949.

200 Allusion to Nikolaj Dobroljubov's portrayal of Katerina, the heroine of Aleksandr Ostrovskij's Groza, which appears already in the title of his 1860 analysis of the play. 
Дорогой Сергей Александрович,

лучше поздно, чем никогда, но иногда бывает слишком поздно. Так и сейчас не знаю - обрадует или рассердит Вас мое письмо. Вы мне и на Рождество и на Пасху шлете поздравления, а я не отвечаю. Но что Вам сказать? Много раз вспоминала Вас и никогда не забывала, но жизнь здесь такая, что нет минуты, нет покоя, нет нужного уединения. Страна новая, страшно любопытная, вся повернутая к будущему. Очень счастлива, что увидела ее - это одно из самых сильных впечатлений моей жизни. Люди здешние совершенно иные, чем в Европе, спокойные, гостеприимные, уверенные в себе; уклад жизни во многом похож на русский, прежний. Красоты - в смысле французском - здесь мало, но Нью-Йорк - грандиозен и прекрасен. В нем есть все, кроме латинского духа, т.е. он похож на все столицы Европы кроме Парижа и Рима.

Могла бы Вам долго рассказывать об Америке, но скажу лучше несколько слов о себе самой. Я приехала сюда в ноябре, переменила 4 профессии в течение трех месяцев, тогда Толстовский Фонд пригласил меня редактировать их месячный бюллетень. Я согласилась. Дело новое, которое я сама организовала. Начальства нет - все делаю самостоятельно. Ответственность несу я за все. Пишу, обрабатываю материал, составляю номер, корректирую, верстаю. Сотрудников нет и помощников нет. Послала Вам только что выпущенный из печати первый номер. Журнал выходит на двух языках. Печатаю 7 тысяч, шесть уже разошлось в 10 дней, успех большой, все хвалят, даже технически. Это конечно не имеет ничего общего с литературой и искусством, но это дело нужное, живое, которое может впоследствии вылиться в ежемесячник. У меня секретарша-американка, кот. мне помогает с английским языком. Денег однако получаю мало - Т. Ф. организация живущая на благотворительность.

Окромя сего вижу много людей, ездила два раза в Харвард в гости к Карповичу, поеду и летом в отпуск к нему. Была в Вашингтоне, где много друзей и знакомых - русских и американцев. Все мне нравится и все интересно. Живу я в меблированной комнате отеля, где мне уютно и хорошо, от русской политики стою довольно далеко, познакомилась с 
пианистом Пастуховым, ${ }^{201}$ с новыми поэтами Елагиным ${ }^{202}$ и Анстей, ${ }^{203}$ с Коряковым, ${ }^{204}$ с Максимовым ${ }^{205}$ - есть среди них люди глубокие и чуткие, но со «старыми« конечно мне легче - они ближе.

Не знаю, когда попаду в Европу - это зависит от двух вещей: от денег и международного положения. Деньги можно для этого раздобыть /я печатаюсь немного в американской прессе/, а междунар. положение темно и неуютно. Во всяком случае, думаю в 1952 году, если не будет катастрофы, побывать в Париже.

Странно сказать, но я чувствую себя здесь необыкновенно внутренне-свободной. Не знаю, отчего это, но это так - внутри развязались как бы все узли и исчезли все острые углы... Страна в общем - удивительная. Жму Вашу руку и шлю Вам свой «ЛОВ«.206

НБ

201 Vsevolod Pastuchov (1894-1967), second-wave émigré pianist and poet.

202 Ivan Elagin (pseud. of Ivan Matveev, 1918-1987), second-wave émigré poet, professor of Russian literature at Pittsburgh University.

203 Ol'ga Anstej (1912-1985), second-wave émigré poet and translator, Elagin's former wife.

204 Michail Korjakov (1911-1977), second-wave émigré publicist.

205 Sergej Maksimov (pseud. of Sergej Paschin, 1916-1967), second-wave émigré prose writer, former GULAG prisoner.

206 Presumably English "love." 
17 декабря 1951

Дорогой Сергей Александрович,

послала Вам несколько дней тому назад рождественскую посылку по всем правилам международной вежливости, а вчера получила милое Ваше письмо, на которое отвечаю. Да, я забросила Вас совершенно письменно, но не мысленно. Жизнь здесь так быстро летит и столько людей и дел, что никак не выкроить время для переписки. У меня на руках бюллетень Толстовского Фонда - работа самостоятельная, с небольшим давлением сверху, оплачивается скромно, но жить можно. О будущем не думаю - и даже не представляю себе еще, где оно будет - здесь или в Европе. Чувствую себя свободной, одинокой и в общем - равнодушной к земным благам. Посмотрю, как все сложится. Пока жить здесь мне интересно.

Вечерами, после года бездействия, очень хочется писать, и это было бы во всех смыслах мне полезно, но устаю, и ленюсь, и выхожу, и принимаю, и стараюсь кое что увидеть в американской среде. Очень довольна, что приехала сюда - увидела новый мир. И многое здесь мне нравится - прежде всего сам город.

Устроилась и внешне очень хорошо: у меня пополам с дочерью Карповича /24 года/ квартира, три комнаты, все удобства в очень хорошем районе. Люди любят приходить к нам. У нее свои знакомые - молодежь, у меня свои. Здесь нет, как во Франции, вечного трагического привкуса в жизни, страдания, сквозящего во всем, обреченности и пр. Так что это некоторый антракт для меня лично, в бурной моей судьбе. И это, конечно, приятно. Вероятно, это только антракт - иначе я это и не рассматриваю.

Есть здесь настоящие друзья, с которыми мне легко и которые кое что для меня значат, но, в конечном счете, сердце мое в Париже. Я только весной или даже к лету смогу решить, буду ли в Европе в 1952 году и на какое время.

Литературная жизнь здешняя меня мало трогает, а политическая - еще меньше. Много новых эмигрантов, с которыми не всегда по пути. Мы для них «эстеты« и они хотят из социалистического реализма выскочить безболезненно в капиталистический - это мне чуждо. Но есть люди очень милые и вообще здесь гораздо более «питореск«, чем в Париже - там нивеллировала старая, могучая культура всех, даже 
простаков. Здесь видишь «нетронутую целину«, во всей ее прелести и безобразии.

Думаю, что мы еще с Вами встретимся - потому что не может быть, чтобы так печально закончилось наше знакомство. Швеция вспоминается как далекий сон и даже Грете я пишу очень редко.

Вы пишете о Бахрахе. ${ }^{207}$ Да, в нем есть очень много симпатичного, но Боже мой! Как он видимо перетрусил: они унесли ноги из сов. газеты, боясь, что их вышлют из Франции, и теперь даже боятся вспоминать о том, что там работали. Адамовичу бедному англичане, говорят, не дают визы из-за этого прошлого. А пять лет тому назад Бахрах /кот. я знаю с 1922 года/ отворачивался от меня при встрече! Не желаю ему за это никакого вреда. Он служил одному господину а я совсем другому. ${ }^{208}$ Спасибо, милый Сергей Александрович, за память. С Новым Годом!

НБ

207 Aleksandr Bachrach (1904-1977), prominent émigré journalist.

208 This is where Berberova confesses. Bachrach catered to Communism, hence he was under Stalin's thumb. She herself was led by another: Adolf Hitler. See also note 220 to Berberova's letter of 30 April 1954. 
Дорогой Сергей Александрович, спасибо Вам за все Ваши письма, за память, за милое ко мне расположение! Ей Богу, я не достойна его, когда вспомню, что столько месяцев оставляла как бы без внимания Ваши письма и открытки. Говорю «как бы«, потому что всякий раз они очень, очень, очень радовали меня и я часто думала о Вас - как то Вы там, в тихой, чудной Швеции, продолжаете смотреть вечерами на огни Мэлара? Постараюсь Вам сказать несколько строк о моей жизни, но сперва хочу еще поблагодарить Вас и за цитаты из Булич о моем романе, кот. мне были очень интересны, и за всякие свои соображения о нем, и за поздравление к именинам и вообще за все, что Вы писали мне и что всегда было мне интересно.

Моя жизнь здесь сложилась... вернее она еㅡ сложилась, и вот почему: я приехала по «туристической« визе, а не квотной, и поэтому я не знаю, останусь ли я здесь или поеду обратно. Есть шансы, что останусь, - тогда, как только это выяснится, я поеду на несколько месяцев в Париж - прогуляться, так сказать. Если это не устроится т.е. чтобы мне здесь окончательно угомониться, то я вернусь в Париж года на два и буду хлопотать о перманентной визе. Если же ничего не выяснится - что тоже возможно, и через пень колоду я буду ждать судьбы, то я не смогу выехать в Европу. Так что жизнь не сложилась еще, а только медленно складывается.

Мне здесь хорошо: здоровье переносит климат чудно, я сама чувствую, что я помолодела и хоть и устаю, но всегда в хорошем настроении. Я работаю интересно - хотя может быть и не вполне, но я довольна, потому что это временно, а там видно будет. Я вижу людей - самых разнообразных, из кот. наименее интересные - литераторы. Я много выхожу, мне часто весело и мне совсем не хочется в Европу. Кое-что я пишу, с Холливудом завела отношения, но пока ничего не устроила, еще не готово... Вообще, должна сказать, имею здесь успех - пожалуй более личный, чем писательский, т.к. люди, в общем, темные, вкусов провинциальных, но как-то так произошло, что литература для меня сейчас не главное - главное увидеть побольше эту интересную, новую страну, людей, которые страшно «пикчуреск«, без наслойки тысячелетних культурных навыков и предрассудков, а просто - какими их создала природа. Я рада, что я сама не совсем такая, но смотреть на них и сближаться с ними - одна радость. Кроме того, Америка страна, где пропадают все комплексы - у меня их и без того было маловато, 
но какие были - исчезли. Да и какие комплексы, если всем все все равно и только бы было удобно и приятно?

А в Париже люди умирают, и стареют, и болеют, и боятся будущего событий мировых и местных. Смоленский пишет, что у него нашли зачатки туберкулеза и отправили его в Шамоникс. Иванов, как слышно, питается даром в инвалидном доме Монморанси, вроде «суп попюлер«; Зайцевы слабеют и дряхлеют, Ремизов слепнет... Как все грустно и как страшно будущее! Сомнений в том, что «закат звезды кровавой« (Тютчев) близится - у меня нет никаких. ${ }^{209}$

Кончаю это письмо, обещаю не забывать Вас, обещаю писать иногда. Будьте счастливы и здоровы!

209 Allusion to Fedor Tjutčev's poem "Ciceron," which refers to "rimskaja slava" and "zakat zvezdy ee krovavoj." 
Новый адрес:

144 West 76 Str. Apt 5D. N.Y. 25, N.Y.

25 августа 1952

Дорогой Сергей Александрович,

Не могу Вам высказать, как я тронута тем, что Вы не забываете. Прошло более четырех лет, как мы не виделись, а Вы все меня помните. И я Вас помню, и вспоминаю, и прошу простить меня, что не пишу. А Ваши открытки каждый раз доставляют мне радость. Сказать Вам правду: за этот год я даже моей милой Грете написала не более трех писем! Происходит это не только по недостатку времени, усталости и пр., но также и от безнадежной мысли, что я так далеко, что увижусь не скоро, что столько есть, что сказать, а уместить в письме невозможно. Вероятно, я поеду в Париж на год - потому что мне необходимо привести в порядок мою визу, - и тогда может быть... Но это, конечно, только мечты.

Жизнь здесь - жизнь другого века. Ничего нет общего с Европой. Все здоровее, проще, грубее, чем у нас. Люди, по сравнению с французами, гораздо добрее, интересуются всем вокруг. Со шведами я их вообще сравнивать не могу - северная сонливость здесь никак не была бы возможна. Климат и пейсаж - какие-то крутые, сильные, мощные, люди же - вместо «Отче наш« сызмальства обучаются психоанализу и самое для них страшное, с чем они борются с молодых зубов, это «комплексы«, так что в массе все более или менее «освобождены«, делают что хотят, когда хотят, иногда не очень это выходит эстетично, но зато всякий чувствует себя здесь на воле.

Русская жизнь очень сложная. Во первых есть «старые«, то есть вроде нас с Вами - культурные, иногда даже утонченные люди, умные, приятные, и должна сказать - их вокруг меня водится несколько. Затем идут «новые«, новая элита, кот. очень любит «хорошо жить«, зарабатывает деньги, отращивает животы, плодит детей, и становится американскими буржуями - иногда люди милые и неглупые. Затем - всероссийские /или скажем всесоюзные/ пьяницы - их громадное большинство и их я не переношу совершенно. Среди них нет гениев, но таланты есть. 
Стараюсь держаться в стороне. Увы, не питаю никакой слабости к алгоголизму и алкоголикам. Затем есть «массы«.

Я ничего не пишу, т.е. почти ничего. Написала пьесу, кот. сейчас переводится по-английски. По правде сказать, писать сейчас не хочется. Жизнь так интересна, что подавляет меня впечатлениями. Американский «социальный заказ« идет мимо меня - требование есть на ужасы концентрационных лагерей и пр. Но у меня чрезвычайно переменилось отношение к собственной профессии и «славе«-мне совершенно стало вдруг все равно. Дело в том, что если говорить языком американцев /отчасти и Фрейда/, то я о с в о б о д и л а с ь «Мысом Бурь« и сейчас не чувствую себя в силах «творить объективные ценности«. Литература стала для меня очень личным и тайным делком, мне совершенно нет никакого интереса к мнении критиков о том, что я пишу, в издании, в постановке, в переводах. Не могу Вам объяснить, но хочу, чтобы Вы поверили, что тут не поза, и не «Мерси« Кармазинова, ${ }^{210}$ и не усталость, а просто очень г а р м о н и ч е с к о е нисколько не трагическое ощущение некоего «довольно« публичности. Может быть это пройдет.

Пока на этом закончу. Рада, что Вы отдохнули, что Вы здоровы и видимо продолжаете Вашу жизнь такой, какую я ее видела когда-то. Как это было давно!

Жму Вашу руку, милый друг.

НБерберова (Attached: a typewritten copy of Chodasevič’s poem "Vtoroe dychanie.”)

210 Karmazinov, a caricature of Turgenev in Dostoevskij's Besy, delivers a verbose address entitled "Merci" from which the narrator ironically distances himself. 
Нью-Йорк 27 марта 1953

144 West 72 str. NYC

Дорогой Сергей Александрович,

я получила Ваше письмо, вернее три письма: поздравление ко дню св. Лючии, затем - посланное через Новый Журнал, и третье - проделавшее дважды путь через океан. Так что ничего не пропало. Сегодня получила письмо от Греты Герелль, где она пишет, что Вы беспокоитесь «не сержусь ли я на Вас« - на что мне сердиться? Разве только на то, что Вы адресуете свои письма мне на 76 улицу, вместо того, чтобы адресовать их на 72-ую и потому они не доходят! Я страшно благодарна Вам за память и милые Ваши строчки, но не пеняйте мне за молчание - Вы ведь тоже на мое последнее письмо л е т о м ответили в день св. Лючии! Плохо, когда при переписке нет (или почти нет) надежды встретиться: если я и попаду в Париж и в Европу вообще, что, конечно, должно случиться, то навряд ли поеду в Швецию - может быть, осталось жить не так много и хочется видеть новые страны... ax, как хочется!

Мне здесь открылся целый мир, главным образом в ВЕЛИКОЙ англо-саксонской современной литературе. В этом году я гораздо свободнее: я устроилась в Голосе Америки «спикершей«, говорю на воздух /оказались хорошие природные данные/ и это, давая мне прожиточный минимум, отнимает не так много времени. Читаю запоем, когда только могу. Объелась романами - замечательными и глубокими, и формально интересными, - и сейчас перешла на Тойнби, ${ }^{211}$ Рассела и др. историков и философов. Наслаждаюсь чрезвычайно, и в библиотеке /городской, откуда беру книги и где есть решительно ВСЕ и даром!/, когда хожу между полками, то, как у голодного перед колбасной лавкой, у меня набегает в рот слюна.

Это определяет мою жизнь отчасти. С другой стороны - сотрудничаю в Нов. Журнале /где прочтите в 32 кн. мой рассказ «Большой Город«/, ${ }^{212}$ в новом сборнике «Опыты«/выйдет в мае/. ${ }^{213}$ А главное - устраиваю свою пьесу в театр на Бродвей - хочу славы и денег. Пьеса хорошая, очень выигрышная, особенная, - я ее люблю, и все ее любят, кто читал. Она превосходно переведена по-английски /она не русская, а

211 Arnold J. Toynbee (1889-1975), British historian.

212 “Bol'šoj gorod," Novyj Žurnal 32 (1953).

213 Berberova, "Iz peterburgskich vospominanij," Opyty 1 (New York, 1953), which describes the end of an entire epoch in Petrograd in 1921-1922. 
международная/и сейчас у меня ведутся серьезные о ней разговоры, уже набирается труппа, и даже первые деньги заплачены. Так что будет, по местному выражению, «трылл « $^{214}$ - для меня, в первый раз в жизни, если не считать маленькую русскую комедию, шедшую в Париже в 1938 году.

Конечно, мысли заняты главным образом, пьесой. Вижу довольно много людей - театральных; все больше - американцев и все меньше русских. Старые - «отмирают«, а новые - чужды в своей «э́ссенс«, и хотя бывает среди них очень приятные и даже верные друзья, но метод их мышления мне, несколько кажется детским, а главное - они /не по своей вине/ не пользуются тем, что есть в мире ДЛЯ ВСЕХ НАС нового и существенного; ведь наш век - воистину золотой - дает каждому, сколько хочешь, «земных плодов « - объесться! - но они этого не видят. Такого богатства мысли, как сейчас - никогда не былко, разве только во Флоренции и во Франции в «великий век«. Все - открыто, все доступно, все лежит, только бери, только успевай насыщаться.

Надеюсь, дорогой Сергей Александрович, что Вы благополучны и стали совсем «свенска маниша « ${ }^{215}$ или как это там - я уже все забыла! Будьте здоровы, шлю Вам искренний привет.

Боголепова антология - позор и ужас. ${ }^{216}$ Маркова - тоже весьма средняя. ${ }^{217}$

Боголепов под Чюминой ${ }^{218}$ поместил стихи Галиной.... ${ }^{219}$

НБерберова

214 трылл $=$ thrill.

215 Svensk(a) människa (Swedish) $=$ Swedish person.

216 Aleksandr Bogolepov, Russkaja lirika ot Žukovskogo do Bunina. Izbrannye stichotvorenija, New York 1952.

217 Vladimir Markov, Priglušennye golosa. Poèzija za železnym zanavesom, New York 1952.

218 Ol'ga Čjumina (1864-1909), poet and translator of Byron. Her writing took on explicitly satirical motifs after the Revolution of 1905.

219 Galina Galina (pseud. of Glafira Ėjnerling, née Rinks, 1870-1942), first acknowledged as a writer of civic poetry in the late nineteenth century. 
Дорогой Сергей Александрович,

Вашей деликатности нет предела: я не ответила Вам на Ваше милое письмо, полученное к Рождеству, а Вы просите у меня прощения за молчание! Это заставило меня сейчас же сесть за ответ. Много есть о чем сказать, но писать - немыслимо. Хотела бы увидеться с Вами, чтобы рассказать Вам о волшебной стране, которая, может быть, многим кажется совсем иной, чем мне, тем многим, которые видят ее авантюрную, или корыстную, или преступную, или спортивную сторону. Но я ничего этого не знаю, так как дорожу временем, которого может быть не так осталось много, и вижу и знаю только то, чего всегда не хватало мне и до чего наконец я «дорвалась«: до книг, которые под рукой, в несметном количестве, на языке, который я теперь знаю и люблю, книг по всем вопросам человеческой мысли - (и меньше всего меня занимает литература), но - археология, геология, история, философия и даже точная наука. До музыки, ибо в радио, которого нельзя отличить от настоящего концерта, каждый вечер я слушаю то, что так дорого сердцу - и все меньше люблю XIX век, с его Листами и Брамсами, которых, по правде говоря, и не слушаю. До тишины, покоя, одиночества и какой то полноты жизненных впечатлений - в самой сердцевине Нью-Йорка, при почти невероятной, почти невообразимой свободе располагать собой, распределения энергии и времени, - ибо давно отбросила всяких «нужных« людей, которые и есть самые не нужные, отбросила какую то провинциально-мещанскую нашу литературу, которая не кормит духовно, конечно, меня; сама не пишу - может быть временно, но совершенно не сетую на это, ибо столько естьчего прочитать, что не до писаний собственных /пока/. Жизнь моя проходит в одной из величайших библиотек мира Публичной Библ. Н.-Й., где лучше, чем в любом храме в мире. Там я работаю, служу, служба интересная, связанная со старыми русскими изданиями, которые переводятся на фильмы - чтобы сохранить для будущего эту затонувшую, эту погибшую и все таки драгоценную для многих старую культуру, о кот. когда то Чаадаев сказал, что она ни с Западом, ни с Востоком не связана, и что она в конце концов погибнет.

Иваска вижу, но его здесь не любят, он как то не пришелся ко двору, тем не менее, он не унывает и мне он скорее мил. ${ }^{220}$ Антология его

220 Jurij (George) Ivask (1907-1986), émigré poet known for his neobaroque style, eventually professor of Russian literature in Amherst, Massachusetts. 
удачная, по моему, и вообще в нем есть что-то, к сожалению, уж очень он не зрелый - ни в каких отношениях, это - болезнь русская и потому русским так трудно на западе, где люди навычены быть зрелыми. 221 Вижу Пастухова, пианиста и поэта, человека «кузминской« эпохи, очень приятного мне. Еще кое кого... но мало. Больше - американцев, которые динамичны и молоды всегда и заставлкяют меня еще и еще жалеть о том, что я не приехала сюда 20 лет тому назад.

В Париж меня не тянет, но все же я поеду туда в будущем году. Многое здесь было трудно, и борьба была довольно тяжелая, но сейчас как будто бы у меня все по немногу «образовывается«. Работала то тут, то там, и в «Голосе Америки« побывала тоже, говорила и писала. Вспоминаю Швецию, как какой то прозрачный и очень тихий сон. Как жаль, что Вы так далеко! Будьте здоровы и не забывайте!

НБ

У Верта - жуткая репутация. Он человек странный.222

221 Ivask, Na zapade. Antologija russkoj zarubežnoj poėzii, New York 1953, which contains Berberova's notorious "Hitler poem" "Šekspiru."

222 See note 464 to Berberova's letter of 5 September 1969. 
Дорогой Сергей Александрович,

давно, давно, не писала Вам, не отвечала на милые Ваши письма, не реагировала на поздравления и вообще - виновата кругом. Сейчас узнала, что В. Булич умерла и, зная, каким она была для Вас другом, мне хочется сказать Вам, что я все эти дни думаю о Вас и мысленно желаю Вам пережить это горе не слишком тяжело. Она была талантлива, но для меня, конечно, очень чужда в ее восхвалениях того, что мне так глубоко всегда было, и есть, и будет враждебно. ${ }^{223}$ Вы снисходительнее меня, а я уж так и умру непримиримая. И не в моей даже власти перемениться. И не то мне не нравится, что там колхозы, или Поля Валери не читают, ${ }^{224}$ или пишут плохие картины, а то, что два наших поколения угробили - рожденных в 1890 и 1910 г.г. /сама я - между ними/.

Но это, конечно, все забудется и порастет быльем: перед тем, что надвигается /когда нас, надеясь, не будет/, это все не так уж, говорят, важно.

Живу я здесь - и ничего больше не пишу! Во-первых - служу. Работа очень интересная /переводятся на фильмы старые русские ценные издания и я этим занимаюсь, через мои руки прошли все тома Русск. Архива, Старины, Журн. Мин. Нар. Просвещения, стенограммы Думы и т.д./ - но изнуряет меня не мало, и нет времени, в сущности, для «покоя« и «воли«, без которых не может быть никакого творчества. ${ }^{225}$ Читаю очень много, люблю многих из амер. и англ. писателей, преимущественно современных - Вы спрашиваете в Вашем последнем письме, кого именно. Гр. Грина, Ивлина Во, ${ }^{226}$ /или лучше их писать в именительном падеже?/ - Грин, Вог, Капоте, ${ }^{227}$ Олдингтон, ${ }^{228}$ Оруэлл, и конечно - Стейнбек, Хемингвуэй /хотя это не оригинально!/, Бертран Рассел, из более старых - Д.Г. Лоуренс, Фицджеральд, ${ }^{229}$ - из совсем старых - Т. Харди, ${ }^{230}$ кот. ставлю наравне с Толстым. Кроме

223 Bulič died on 21 July 1954.

224 See note 321 to Berberova's letter of 20 March 1962.

225 Allusion to the fifth line of Puškin's poem "Pora, moj drug, pora!" (1834): "Na svete sčast'ja net, no est' pokoj i volja."

226 Evelyn Waugh (1903-1966), English novelist, author of Brideshead revisited.

227 Truman Capote (1924-1984), American writer and journalist, author of the much-noted novel In cold blood (1965).

228 Richard Aldington (1892-1962), English poet, known especially for his poems from the trenches of WWI.

229 Scott Fitzgerald (1896-1940), American novelist, author of The great Gatsby.

230 Thomas Hardy (1840-1928), English novelist and poet. 
того читаю философов и эссеистов, из последних Л. Стрэчи, ${ }^{231}$ кот. всегда люблю. Вообще читаю без конца и только втянувшись, конечно, можно питаться этой литературой, по началу она может показаться очень «острой«. Еще есть Патон ${ }^{232} /$ Юж. Африка/ и Райт ${ }^{233} /$ негр/; драматург Т. Вильямс... ${ }^{234}$ Всех не перечесть.

Самое удивительное, что я не чувствую себя несчастной не видя более в печати своей фамилии! Жизнь интереснее литературы. Иногда, в редкие минуты, приходит в голову мысль о том, что в сущности НИЧЕГО путного не написано мною - кроме двух-трех рассказов и двух-трех стихотворений. Но в душе нет горечи - считаю, что и на том спасибо.

Я очень ценю, дорогой Сергей Александрович, ваше милое отношение - нашу дружбу, кот. не прерывается, несмотря на такую длительную разлуку. С Гретой Герелль я в переписке, она переехала теперь на Мэларторгет, 15, и говорит, что из окна у нее дивный вид, чему я вполне верю. Она зовет меня, - а я зову ее в Нью-Йорк. Неужели может случиться, что я приеду в Швецию? Все бывает!

Жму Вашу руку. И если я молчу, то не потому, что неверна Вам в дружбе.

НВерберова

Пожалуйста, прочтите Автобиографию Хавелок Эллиса (Havelock Ellis). ${ }^{235}$ Гениальная книга. ${ }^{236}$

231 Lytton Strachey (1880-1932), English biographer, a founding member of the Bloomsbury group.

232 Alan Paton (1903-1988), South African writer and politician.

233 Richard Wright (1908-1960), American writer known especially for his autobiographical novel Black boy.

234 Tennessee Williams (1911-1983), one of the greatest American twentieth-century playwrights.

235 Havelock Ellis (1859-1939), physician, psychologist, sexological pioneer who in certain respects anticipated Freud. He was the first to write dispassionately about homosexuality.

236 My life. Autobiography of Havelock Ellis, Boston 1939. 
18 сентября (1954)

Дорогой Сергей Александрович, всего - два слова, потому что чувствую, что не могу Вас оставить в неведении касательно случившегося со мою: я три дна тому назад вышла замуж за моего дорогого и близкого /вот уже два года/ друга, музыканта, пианиста и преподавателя рояля - Георгия Александровича Кочевицкого, нового эмигранта /с 1941г./, - и очень этим событием счастлива. ${ }^{237}$ Он - петербуржец /конечно!/, окончил консерваторию у Николаева в свое время. ${ }^{238}$ Ему столько же лет, сколько и мне.

Пожалуйста, позвоните по телефону Грете Герелль (Mälartorget 15) и скажите ей об этом, а также, что я напишу ей через несколько дней, когда уляжется немножко жизнь в новые нормы. Скажите ей, что я просила Вас ей сообщить немедленно, потому что мне надо собраться с мыслями, чтобы ей подробно все отписать.

Пока все. Адрес мой новый, сообщите Грете и сами запишите в книжечку. Я переехала к Г.А., но мы ищем «настоящую« квартиру - потому что у него два рояля и очень тесно. У меня впечатление, что я попала в клетку к двум слонам.

Жму Вашу руку, милый друг.

Н. Б.-К.

Mrs Nina Kochevitsky

444 West 57 Str.

New York, N. Y.

237 Georgij Kočevickij (George Kochevitsky, 1902-1993), Russian-American pianist, Berberova's third husband.

238 Leonid Nikolaev (1878-1942), pianist and piano teacher in Leningrad. 
Дорогой Сергей Александрович,

как я рада, как я рада, как я рада, что Вы были в Париже! Правда, меня там не было, и это ужасно жаль, но я бескорыстно счастлива за Вас. Боже, как хорошо, что Вы проветрились, что повидали чудный этот город, и наверниое тоже повидали старых, несчастных, выцветших и полинявших русских литераторов. Напишите мне, кого видели, кого полюбили, а кого только пожалели, а кого разлюбили... Где Вы останавливались? Кто был Вашим чичероне? Не было ли мимолетной, но незабываемой встречи, не кипел ли огонь в крови? /Без этого - какой же Париж?/ Словом, жду Вашего письма, дорогой Сергей Александрович. Очень жду.

Мой муж тоже в Париже был в это же время. Он выехал в Европу на три месяца /он уже американец/, а я поеду, когда получу гражданство /через два года/. И ему /как и Вам/ я тоже не завидовала, а только радовалась тому, что он побудет в Париже, Риме, Флоренции, Венеции, Швейцарии, Германии, Голландии и Дании.

Я давно не писала Вам. Жизнь моя бежит... Я служу, и собственно существование мое начинается в 5 часов вечера. Есть друзья, много читаю, много слушаю хорошей музыки, чувствую себя в равновесии душевно-духовном /очень позитивном/ и несколько «умудренной« - не улыбайтесь. Писать не хочется. Пишу стихи, не дописываю, теряю, выбрасываю, печатать нет охоты. Как сказал Иванов - слушают и читают нас /за малыми исключениями/ «дураки и дуры«. Все стала принимать кум грано салис 239 - и жизнь стала звучать от этого поиному, как-то веселее, как-то легче.

Я думаю сейчас о том, что Вы наверное вошли в контакт с Петербургом - по теперешним временам не только можно туда писать, но может быть кое-кому можно будет и поехать туда? Как Ваша сестра и муж ее, талантливый писатель? Отсюда ездил в Москву, на съезд славистов, Роман Якобсон и вернулся в полном восторге /он по природе всегда был несколько розоват/. ${ }^{240}$ Говорит: и Карповичу можно смотаться туда. Неужели это правда?

239 Cum grano salis $($ Latin $)=$ with a grain of salt.

240 Roman Jakobson (1896-1982), the great Russian-American linguist, professor at Harvard. 
Эти «послабления« все же не значат для меня слишком много: события в Познани это доказали. И в конечном счете генеральная линия ведется на дальний прицел - консолидация комм. идеологии.

Получаю письма от Греты и должна сказать, что они меня тревожат. Она как то совсем замерла, засохла, заглохла в своем углу, с видом на Мэларторгет. Антропософия ее законсервировала и отняла жизнь, юмор, охоту к путешествиям. Это все - факиры!

Прочтите пожалуйста чудную книгу: Юрсенар /франц., но переведена на все языки/ Мемуары Адриана /римск. императора/. Что за книга! ${ }^{241}$ Я тут больше читаю английское. Есть очень замечательные писатели, и в Америке, и в Англии. Конечно, люблю теперь тех, которые кум грано солис.

Жму Вашу руку. Никогда не забываю, как Вы были милы и гостеприимны в Стокгольме, когда мы гуляли вместе и говорили о Шиллере, о славе, о любви /впрочем, о любви мало/.

Привет.

НБерберова

241 Marguerite Yourcenar (1903-1987), Mémoires d'Hadrien, Paris 1951. 
Nina Berberova 444 West 57th Street

New York 19, N.Y.

Phone: 017-6536

5 августа 1956

Дорогой Сергей Александрович, спасибо за чудное письмо, из которого я ясно увидела Вашу милую фигуру, эстета и сибарита, бродящую по улицам Парижа. Вы видели многих и наверное остатки «великой русской словесности« успели Вас оценить и полюбить - не сомневаюсь. Присманову я тоже очень ценю и люблю, не знаю, как она относится ко мне теперь, но мы даже в 1950 г. с ней перешли на «ты«. Гингер отличный человек, но поэт плохой; его спасает «священное безумие«.

Я через неделю уезжаю на месяц в места странные и дикие: еду в Колорадо, Аризону и Новую Мексико. Хочу посмотреть совсем другую, величественную и грозную Америку, а не ставшие совсем уже ручными небоскребы. Увижу красные горы, зеленые небеса, каньоны, пустыни, скалы, похожие на готические соборы, индейцев, пляшущих дикие танцы и полуголых красавиц. Напишу Вам по приезде обратно. Я стала писать стихи, и Вы прочтете их в Новом Журнале. Я делаю это с большой радостью и без всякой оглядки на критиков - желание вдруг сказать что то.... но не в прозе! Форма не очень модная, но написаны они всерьез и одно из них - про Гольфштром, из кот. мы все возникли /западники/ - я сама люблю. Впрочем, я сейчас все пять люблю, хотя знаю, что есть в них недостатки. Но глагольные рифмы я перестала считать недостатком. Пусть живут! ${ }^{242}$

Мой муж сейчас в Австрии, он видел Париж, Рим, Неаполь, Флоренцию, Венецию... Письма его совершенно безумны. Я думаю, он не ожидал, что все будет так прекрасно, щемяще-прекрасно, невозвратно и драгоценно. Как я счастлива, что он поехал в Европу! После 30 лет Советского Союза, концлагерей и пайков - это необходимо. Хотя в нем нет ничего от «советского хомо сапиенс«, а все таки нужно видеть все это, чтобы стать человеком «от Гольфштрома«.

Грета и фру Асплунд сейчас находятся на Хеммаре и будут дома после 15 го августа. Очень буду рада, если позвоните Грете и передадите ей не только приветы Аси и Володи Злобина, но и расскажете о том мизере,

$\overline{242}$ See note 243 to Berberova's letter of 25 December 1956. 
в кот. живут парижане. Она немножко, по-моему, забыла, особенно о Володе. Вообще ее антропософия меня стала беспокоить: ей все - все равно, и нет больше ни тревоги, ни пыла, ни любопытства к миру и людям, а только покой. «Не трогайте мои весы!« - как сказал когда то один забытый поэт. И с этим вместе пришел страх - страх шума, холода, жары, бедности /!/, далекого путешествия и т.д. Может быть она больна? /Т.е. не проходящей болезнью, а какой нибудь настоящей и скрытой/.

Жму Вам руку. Если не пишу, то это решительно не значит, что я забыла Вас, Тиволи, синий берет, квартиру на Мэларе и все вообще. Это только значит, что нет минутки.

НБерберова 
С Новым Годом, дорогой Сергей Александрович! Получила Вашу карточку к праздникам и - уже очень давно - письмо Ваше. От Греты знаю, что Вы звонили ей... Очень бы хотела о многом с Вами поговорить, о важном и неважном, о прошлом и будущем, о Вас, обо мне, о русской «словесности« и прочих хороших вещах. Когда это состоится? Сквозь магический кристалл я начинаю различать 1959 год.

Сначала отвечу на Ваш - уже давний - вопрос о Вашей поездке в СССР. Почему не рискнуть? Если Вы любите сестру свою и думаете, что свидание с нею будет Вам полной и длительной радостью, то надо ехать. Если же Вы предполагаете, что Вас могут арестовать, сослать, не выпустить обртатно, - то, конечно, о поездке не может быть и речи. Мне трудно вообразить себя в Вашем положении: ни при каких обстоятельствах я бы не поехала, то есть абсолютно ни при каких. Здесь я вижу людей, кот. побывали этим летом в СССР - американцы, конечно. Безрадостны их впечатления. Вот уже два месяца, как все здесь, в том числе и я, потрясены событиями: Венгрия и Суэц. В ноябре я совсем пала духом, не могла ни читать, ни работать, ни слушать радио, хотелось лежать носом к стенке - как было в сентябре 1939 года. Мир опять стоит перед страшной катастрофой, результаты которой может быть будут положительны /как результаты войны 1914 и 1939 г.г./, но цена будет заплачена страшная, пожалуй такая, от которой сто лет не оправится мир, если и оправится. Жизнь в конце концов есть цепь безвыходных положений - так и в политике. И смысл ее - искать выходов в этой безвыходности.

Вы спрашиваете, почему я не печатаюсь /или не пишу/. Я пишу стихи. Пять из них напечатаны в Новом Журнале /в последней книжке/. Напишите мне, понравилось ли Вам «Карибское море« - я его очень люблю, что бывает со мной редко. ${ }^{243}$ Что касается русской печати, то я совершенно перестала ее читать: ни Русской Мысли, ни даже здешней газеты никогда не вижу: нет «корма« в них, а время дорого. Корм нахожу в изобилии - только успевай его брать! - но не в русской печати, ни здесь, ни там /где в Новом Мире советую Вам почитать

243 Berberova published five poems, among which "Karibskoe more," in Novyj žurnal 46 (1956). 
роман - печатался с весны до осени - где действие происходит в Сибири, никогда не видавшей апельсинов/..244

Грета пишет мне - вот уже шесть лет - что она тяжело больна, между тем я не могу понять Ч Е М? Сердце? Кишечник? Нервы? Одно время сестра ее намекала мне, что у нее рак. После этого как будто все прошло. Ее невероятная мнительность меня ужасно огорчает. Оставим это все между нами, но мне тревожно за нее и я не нахожу ничего утешительного в ее письмах. Наоборот. Как бы мне хотелось увидеть ee! Боже, десять лет прошло уже со дня моего первого приезда, наших разговоров, чудной прогулки в Тиволи... Но несмотря на мои долгие молчания, Вы, милый, дорогой друг, все так же пишете мне и помните меня. Если бы Вы знали, как Вы меня этим трогаете!

Желаю Вам счастья и здоровья в Новом Году. Крепко жму Вашу руку. Г. Алекс. шлет привет. Мы с ним живем дружно. Этот мой третий брак ни в чем не похож на предыдущие. Он совсем в другой тональности.

НБерберова

244 Berberova has discovered the village prose sketch writer Valentin Ovečkin (1904-1968). His "Trudovaja vesna," which is part of the cycle "Rajonnye budni," was featured in three issues of Novyj mir (3, 5 and 9) in 1956. 
Дорогой Сергей Александрович,

вчера пришло Ваше письмо. Вы не забываете меня, но и я никогда не забываю Вас, и воспоминания о Стокгольме, переплетенные с воспоминаниями о Хеммаре, о Грете, неизменно упираются в Ваш милый, дружественный образ /обрис - как говорила одна дама-писательница, смешивая образ и абрис/. Сегодня же пришло письмо от Греты, и я так рада, что Вы с ней поддерживаете изредка отношения - телефонные, увы! Боже, что с ней?? Она полный инвалид, но если это так, то почему она одна, лежит одна, одинёшенька, иногда плачет от депрессии /?!/ - ведь это просто бесчеловечно так ее оставлять, хотя я думаю, что это конечно по ее собственному желанию. Почему в Швеции такие странные отношения между людьми, или это специально у нее такие тенденции - одиночество, гордость, независимость, чуть ли не на смертном одре. Здесь тоже бывают сердечные припадки у людей - и даже весьма часто; держат людей в госпитале семь недель, потом шесть месяцев они на полу-инвалидном положении /Эйзенхауер, ${ }^{245}$ впрочем, меньше был/, но выходят /если не умирают/ из этого состояния нормальными людьми. Я просто теряюсь в догадках - почему сестра и ее давний друг, г-жа Асплунд, ее не возьмут к себе?? Она пишет мне часто, чаще чем я ей. И я стараюсь всегда ее подбодрить, не задавать ей вопросов. Но доколе она будет полумертвецом, и что это за лечение? Может быть когда-нибудь у Вас будет желание позвонить ее сестре, Наде тоже Герелль, ${ }^{246}$ живущей /во всяком случае - жившей - на Свеавеген 126, телефон: 32-33-86/ и спросить ее, от моего имени, что с Гретой, когда она вернется к жизни? - я бесконечно беспокоюсь о ней и ужасно так ничего по-настоящему не знать. Надя знает, что Вы мой друг. Вы все это сумеете сделать тактично и деликатно.

Грета мне пишет, что Вы недовольны, что нет моего имени в печати. Милый Сергей Александрович, куда, зачем, кому, для чего, о чем? Впрочем, о чем - есть, конечно, да я и пишу понемногу стихи, кот. Вы прочтете когда-нибудь в Новом Журнале - если я их кончу, /начато более десяти и пишу постепенно/, если будет Нов. Журнал и если

245 Dwight David Eisenhower (1890-1969), President of the United States (1953-1961).

246 Nadja Gerell (1901-1976), bank employee. 
мы еще будем живы. Во что превратилась русская литература? Не хочется писать об этим. О газетах наших. О журналах. О «мысли«, кот. остановилась, как усталая, заезжанная лошаденка - нет, русская литература вот уже лет 20 меня «не кормит« ничем... Откуда же мне, и зачем, и кому, давать пищу - слишком это большая роскошь для меня сейчас. Хочу сама еще напитаться всеми роскошествами запада. Хлеб насущный зарабатываю тем, что служу в конторе /не всегда легко/ 35 часов в неделю. А остальное время - вот чего только нет вокруг, только успевай брать!

Я не ленива, и многое прочла за это время, и по правде говоря - легче стало жить /духовно/. Трудно в письме сказать обо всем, но на все /да, милый друг, все/ «проклятые вопросы ${ }^{247}$ - более или менее ответ найден, годы идут и я не боюсь ни старости, ни смерти, живу в постоянной и радостной гармонии внутренней - к которой привело меня абсолютное и окончательное н е в е р и е. Все это кратко и бледновато звучит в письме - в разговоре было бы иначе. Но цель человека освобождение от всех узлов, какие завязались в первые сорок лет его жизни, и, после трудных лет, у меня таких узлов не осталось. Но все это не должно звучать для Вас мажором - о нет! Слишком подо всем колышется хорошая «минорная« почва.

У Г.А. есть друг в Хельсинки - его брат недавно ездил в Питер. Пришло от них письмо на восьми страницах. Как все это просто теперь и как, видимо, безопасно и дешево! Может быть и Вы съездите? Когда Вы написали мне о том, что у Вас могут быть такие намерения, первая моя реакция была - страх, что Вы там пропадете. Но теперь мне кажется, что Вы могли бы поехать к сестре. Напишите мне, что думаете об этом, и были ли какие-нибудь Ваши друзья там?

Я не читаю русских газет совершенно. Недавно прочла сборник, так называемый «сборник Керенского« /с кот., между прочим, я дружу/. Пахнуло началом века, или концом прошлого. Бескорыстно, и даже с «идеалами«, - но до того старомодно и «нот то де пойнт « ${ }^{248}-$ как говорят американцы. Называется сборник «Судьбы России« - он полон предсказаниями того, чего желают авторы. Какое для них самих утешение! Но не для читателей. ${ }^{249}$

247 The damned questions - from Heinrich Heine's poem "Zum Lazarus" (“die verdammten Fragen").

248 Not to the point.

249 Sud'by Rossii. Sbornik statej, New York 1957. 
Набоков издал по-английски за последний год два романа: один «Лолита« - запрещенный (более или менее) цензурой за «безнравственность« и другой «Пнин« - о русском профессоре в американском университете. Обе книги замечательные. Вот для меня два события - но оба уже не русские. Здесь среди русской литературной группы есть пять-шесть человек, кот. встречаются, держатся особо, но не пишут или почти не пишут, и, собственно, не культивируют «дружбы« - а просто связаны парижским прошлым /или даже не парижским иногда, а петербургским, или вообще - «столичным мировоззрением - Вы понимаете, что это значит/. К ним принадлежат, кроме самой меня, Яновский, ${ }^{250}$ Варшавский, ${ }^{251}$ Извольская, ${ }^{252}$ пианист и отчасти поэт Вл. Пастухов, Иваск, не живущий в Н.-Й., и может быть даже Роман Гуль. ${ }^{253}$ Вот и все. Если прибавить к ним Набокова /кот. никто не видит, т.к. он всех презирает - не изжитая детская болезнь/, Адамовича, кот. хиреет в Манчестере, Иванова и Одоевцеву, кот. едва живы, то это будет ВСЕ. Зайцев и Ремизов очень стары, больны и немощны.

Милый Сергей Александрович, мы еще увидимся, я в это верю. В 1959 г. я собираюсь в Европу и мы «спланируем« что-нибудь - встречу в Париже, может быть... Что Вы скажете на это?

Жму Вашу руку. Не сердитесь, что иногда замолкаю надолго: жизнь бежит, времени мало, а иногда нет и сил - устаю.

250 Vasilij Janovskij (1906-1989), émigré prosaist, critic, physician.

251 Vladimir Varšavskij (1906-1978), émigré prose writer and journalist.

252 Elena Izvol'skaja (1896-1975), émigré writer on Catholic themes.

253 Berberova had a complex relationship with writer and periodical publisher Roman Gul' (1896-1986). He featured many of her works in Novyj Žurnal but later severely criticized her memoirs Kursiv moj (see notes 480 and 485 in Berberova's letter of 22 November 1969). 
430 Вест 57 улица

Нью-Йорк 19

14 сентября 1957

Дорогой Сергей Александрович,

вчера получила Вашу открытку. Так приятно было представить себе Вас и Грету вместе, спасибо, что вспомнили обо мне! Ваши письма все получила - сперва Вы молчали долго, а потом - я. В июле ко мне приезжала из Парижа моя подруга /француженка/, с кот. я не виделась больше шести лет. Это было мне большой радостью. Месяц мы провели с ней у моря, в местах красивых, старомодных, но теперь постепенно входящих в моду, перегруженных автомобилями и крикливыми дачниками, но все еще элегантских и чем-то напоминающих места нашего детства. Теперь вернулись, и я уже хожу в контору - которая крепчайшим образом меня надоела.

В Мюнхене Общество Эмигрантов начинает выпускать журнал, четыре книжки в год, и я приглашена секретарем редакции, с довольно большими полномочиями, так что вероятно службу в конторе брошу и буду Вас /среди прочих/ просить о сотрудничестве. ${ }^{254}$ Милый друг, Вы столько видели, думали и читали всю свою жизнь, что пора поделиться с людьми кое-чем, пора взяться за перо и писать. Вы спросите меня: а Вы сами? И я буду писать тоже. В России по-моему идут какие-то перемены, они будут идти медленно, но все-таки идти, и мне кажется, что сейчас время издавать журнал, повернутый несколько туда - в смысле интереса, не в смысле политическом. Жить буду в Н.-Й., но работа с Мюнхеном облегчит мне поездку в Европу. Общество же называется Центр. Объед. Политич. Эмигрантов и главным образом в него входят люди, вышедшие из СССР после 1941 года. У них в Мюнхене своя типография и они уже выпускают несколько лет иллюстрирорванный /по своему не плохой/ журнал Свобода. ${ }^{255}$

Мы здесь получили очень интересные письма из Финляндии от людей, ездивших в СССР. Год назад Вы спрашивали меня, ехать Вам или не ехать, и я писала Вам, что боюсь за Вас. Сейчас я бы пожалуй так не сказала: мне кажется, что съездить можно. Возможно, что Вы

254 Mosty, the first volume of which appeared in 1958.

255 The Central Association of Soviet Political Emigres (Central'noe Ob"edinenie Političeskich Ėmigrantov iz SSSR, TsOPE்) was formed in 1952. It became successively less active under the course of the 1960s. In 1952-1963 it published the journal Svoboda. 
даже захотите остаться там, - но этого я бы не сделала. Напишите мне, в каких Вы сейчас настроениях касательно этого вопроса. Переписываетесь ли с сестрой? Ю. Г. как-то не был слышен в той шумной и очень интересниой полемике о свободе творчества, кот. продолжалась около шести месяцев и кот. теперь прекратили. ${ }^{256}$ Но мой старый друг юности, Каверин, в ней блистал. ${ }^{257}$ Поражена была узнав из Вашей открытки, что Таскин побывал в Стокгольме. ${ }^{258} \mathrm{OH}$ поспел всюду, какой молодец! Милейший человек. Когда увижу его, надеюсь, он мне про Вас расскажет. Милый Сергей Александрович, я думаю, что самое позднее в 1959 году я буду в Европе и тогда мы с Вами увидимся, - где-нибудь в Париже. Напишите мне откровенно, какое впечатление на Вас произвела Грета. Она все еще беспокоит меня - письма продолжают быть овеяны тоской, я бы сказала какой-то отчетливой шведской тоской. Жму Вашу руку.

НБерберова

256 Jurij German.

257 Veniamin Kaverin (1902-1989).

258 George (Jurij) Taskin (1893-1964), Russian-born New York professor of Geography. 
(Undated, December 1958)

Дорогой Сергей Александрович,

желаю Вам всего лучшего в Новом Году. Сейчас я дома, в Нью-Йорке, а то все - в Yale, в университете: 3 курса языка, и 1 литературы. Много работаю; прочитайте пожалуйста мой «шведский« рассказ в янв. № Нового Журнала и напишите, что думаете. ${ }^{259}$ Жму руку.

НБерберова

259 “Mysljaščij trostnik,” Novyj Žurnal 55 (1958). 
30 дек. 1958

Дорогой Сергей Александрович,

из Вашей карточки, пришедшей вчера, я не поняла, получили ли Вы или еще нет мою поздравительную карточку? Так, по большим праздникам, мы с Вами перекликаемся с одного конца мира на другой. Но тон Ваш был такой грустный, что я сразу поняла: Вам не до Рождества и Нового Года, а хочется писать совсем о другом. Почему Вы этого не сделали, а следовали какой то традиции, которая не так уж и необходима? Напишите же мне поскорее, что с Вами. Предполагаю, что Вы больны - о том мне написала Грета. Пожалуйста, напишите обо всем, и почему такое печальное настроение, и какие планы в связи с Вашими прежними мыслями о поездке к сестре, и как поживает наш дорогой Стокгольм - о кот. Вы прочтете в последнем номере Нов. Журнала. ${ }^{260}$ И Ваше мнение для меня страшно важно: вышел ли у меня город?

Но может быть Вам не до того, дорогой мой друг, и тогда ничего не читайте и ни о чем не думайте, а только напишите мне о себе, и что с Вами происходит. Кто у Вас близкий в Стокгольме, есть ли друг (или подруга), кот. навещает Вас и согревает Вас? Я буду ждать Вашего письма.

О себе скажу два слова, потому что думаю, что Вы сейчас не очень интересуетесь посторонними делами: я преподаю в Йельском университете вот уже три месяца, сначала только язык, а теперь у меня курс литературы, а в будущем году будут два курса. Не буду распространяться, что это значит: скажу только, что в Йеле 1. Вообще женщин нет, 2. Без американского диплома не принимают даже на порог. 3. Берут только молодых. Так что «честь« огромная, и отношение такое, будто я - «бабушка русской литературы« (впрочем, может быть, это скоро и будет?). ${ }^{261}$ Живу я там пять дней в неделю, а на субботы и воскресенья приезжаю в Нью-Йорк. Там завела друзей, вокруг народу довольно много, и пожалуй даже больше, чем в Н.-Й. Все - молодые, много талантливых, американская профессура (слависты). Один читает курс по Пушкину (и специалист по Вяч. Иванову), другой - по Достоевскому, третий по Толстому. Словом, у меня жизнь интересная, сил много еще

260 "Mysljaščij trostnik." Rittenberg’s archive contains a copy of the text ripped out from the journal with the dedication: "Sergeju Aleksandroviču na pamjat' o našich Stokgol'mskich progulkach. NB. 26 janv. 1959".

261 Cf. Ekaterina Breško-Breškovskaja's (1844-1934) epithet: "babuška russkoj revoljucii." 
как будто. Альманах в Мюнхене вышел, называется «Мосты« - не все в нем удачно, а кое-что и ску-у-учно, - я Вам пришлю экземпляр, как только он прибудет в Америку - впрочем, я написала в Мюнхен, чтобы Вам прямо послали книгу оттуда. ${ }^{262}$

Голубчик, не унывайте, лечитесь и не падайте духом. Черкните мне. Крепко жму руку.

НБерберова

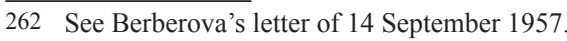


Дорогой Сергей Александрович,

вчера получил Ваше письмо и спешу написать Вам несколько слов. Как я рада, что Вы чувствуете себя лучше, надеюсь, что Вас вылечили совсем и что Вы уже начали работать. Я тоже в первый раз в жизни в этом году читаю лекции - если знать предмет вдоль и поперек, то это не страшно. А внимательные лица слушателей наверное Вас вдохновляют, как и меня.

Ваши слова о «Тростнике« принимаю только на 49 \%, а 51 \% отношу за счет Вашего милого ко мне отношения. Но и то, что остается, очень много. Я получила довольно много писем от полу-растерянных мною старых друзей - всем нравится «Тростник« больше «Шлимана« - но «Шлиман« сидел во мне 5 лет и должен был наконец выйти! ${ }^{263}$

Сейчас я тут в New Haven (Yale University) сняла маленькую квартиру и Георгий Алекс. иногда приезжает из Нью-Йорка, но больше я езжу к нему «домой«; утомительно, но ничего не поделаешь, особенно в первый «академический« год: надо делать максимум. Вот и летом вероятно буду читать лекции на летнем семестре - будет свободный июнь и начало сентября. Планов пока никаких. Хочется писать, но нет внутреннего покоя и мешает бурная жизнь вокруг. Вообще не все (было) легко. Одна надежда, что это уже действительно mon dernier effort ${ }^{264},-$ кажется, на новые неспособна. Вообще же, принимая во внимание международное положение, бомбы, Китай, спутников и пр. отношусь к «последнему этапу« довольно равнодушно. Им будет заплачено за все хорошее, что было.

Крепко жму Вашу руку.

263 Berberova's story "Pamjati Šlimana" was published in Mosty 1 (1958).

264 mon dernier effort (French) $=$ my final effort 
1 сентября 1959

Дорогой Сергей Александрович, как я обрадовалась Вашему письму! Во первых потому, что из него я поняла, что Вы совершенно здоровы, во вторых - я разделила Вашу радость от того, что Вы видели Петербург и сестру, и в третьих - все было так интересно и важно, что Вы написали, что я и сказать Вам не могу. Хочу еще знать подробности о городе и людях. Поедете ли Вы еще раз? Не думаете ли, что сможете там остаться жить? Времена меняются. Все может быть, все может быть... Возвращаюсь к Вашему письму. Каверин, Фиш, ${ }^{265}$ Рождественский ${ }^{266}$ (как и многие другие, которых не убил Сталин) друзья моей молодости. Не думаете ли Вы, что я могла бы послать кому-нибудь оттиски моих последних рассказов? Читают ли они Новый Журнал? Я бы хотела узнать о многих, но пока я хочу Вас попросить п р и с л уч а е навести следующие справки: что сталось с Колей Коварским ${ }^{267}$ /Где Шкловский?/ Лидия Попова, я подозреваю, Лида Чуковская. ${ }^{268}$ Если это так, нельзя ли передать ей, что Женя Лунц, моя близкая подруга, сестра покойного Левы, ${ }^{269}$ шлет ей привет? Где Ида, урожденная Наппельбаум, которая была замужем в 1930 году за Мих. Фроманом (кот. погиб). ${ }^{270}$ Это моя ближайшая подруга в 1922 г., ученица Гумилева и участница Звучащей Раковины ${ }^{271}$. Она дочь фотографа и сама фотограф, на углу Невского и Литейного, очень известного. ${ }^{272}$ У нее была сестра Фрида, кот. тоже писала стихи и кончила университет в Петербурге. ${ }^{273}$ Каверина я люблю и ценю, и так хотелось бы знать о нем побольше. Рождественский Вс. - не мог забыть меня. Мы с ним очень дружили, и даже один раз поцеловались.

Все это я пишу на случай, если Вы поедете опять. Сообщите мне, если это случится. Я попрошу Вас пойти в один дом, где умерли мои родители во время немецкой осады.

265 Gennadij Fiš (1903-1971), prose writer and friend of Scandinavia.

266 Vsevolod Roždestvenskij (1895-1977), poet.

267 See note 172 to Berberova's letter of 8 February 1950.

268 Berberova is mistaken. Lidija Čukovskaja (1907-1996).

269 Lev Lunc (1901-1924), playwright, member of the Serapion Brothers. See Kursiv moj, 161-163.

270 Michail Froman (1891-1940), poet, translator, Ida Nappel'baum's husband. He was not "repressed," but died of illness.

271 Ida Nappel'baum (1900-1992), poet and photographer. See Kursiv moj, 159 ff. The poetry studio "Zvučaščaja Rakovina" (1921-1922) was at first led by Nikolaj Gumilev.

272 Moisej Nappel'baum (1869-1958), legendary photographer. After Gumilev's execution his students met to read poetry and socialize in Nappel'baum's photography studio on Nevskij prospekt.

273 Frida (Frederika) Nappel'baum (1901-1958), poet. 
Сама я наконец твердо решила быть в Европе в будущем году. Где и когда мы можем съехаться? Об этом надо подумать заранее. Мой план такой: в конце мая я приеду на неделю к этой самой Жене ЛунцХорнштейн, под Лондон. Июнь весь проведу в Париже. В июле поеду на неск. дней в Германию - по делам в Мюнхен и в гости во Франкфурт, затем - в Италию, где буду 2 недели «лечиться« в Монте Катини водами (никаких болезней нет, просто отдохну), а затем до конца августа буду жить в Италии, и только съезжу на 10 дней в Грецию. Вернусь в Париж около 1 сент. и около 10-го выеду в Америку. Этот план более и менее установлен. Я, конечно, хочу повидать и Грету, хотя бы на неск. дней где-нибудь...

Здесь у меня все идет успешно. Работала на летнем семестре. Много новых друзей. В только что вышедшем номере Нов. Журнала моя большая статья «Набоков и его «Лолита«« - непременно прочтите. ${ }^{274}$ Будет в дальнейшем и рассказ большой - если журнал найдет деньги и будет продолжаться: положение критическое, да и Карпович тяжело болен. Пора, пора Хрущеву реабилитировать не только мертвых, но и живых!!

21 сентября начинается зимний семестр. До того я свободна, живу частью в Нью-Йорке, частью в Йеле. Пишите в Йель. А впрочем, пишите куда хотите, потому что это не важно. Я много читаю, особенно по английски. Здесь есть замечательные критики (в высоком смысле слова), от которых я многому научилась. Хочется писать с т а т ь и на литературные темы, но кажется скоро будет совершенно негде их печатать. Мюнхенские «Мосты« (видели ли Вы второй номер?) - род Задушевного слова, плюс некоторая доля вульгарности и большая доля скуки. Я все еще там «член редколлегии«.

Жму Вашу руку, милый друг, радуюсь, что увижу Вас, время бежит быстро, будьте здоровы. Вадим Андреев, о кот. Вы спрашиваете - 100 проц. советский человек, живет в Женеве, работает в сов. делегации ООН, имеет сов. паспорт с 1946 г. С эмигрантами не водится и не кланяется, и мы ему тоже не кланяемся. В Ленинград ездит и всем доволен.

Ваша

НБерберова

274 Berberova, "Nabokov i ego 'Lolita," Novyj Žurnal 57 (1959). The story to be published (in the next issue) is "Černaja bolezn'." 
430 West 57 St.

New York 19, N.Y.

или

6 Lynwood Pl.

New Haven, Conn.

12 декабря 1959

Милый Сергей Александрович,

все Ваши письма получила, открытку и т.д. Занята была очень, потому молчала, но Вы знаете, что я не изменяю и не изменяюсь по отношению к Вам - Ваше дружеское, хоть и не-материализированное, присутствие в моей жизни перманентно. А в будущем году летом я надеюсь увидеться с Вами на самом деле. Будете ли Вы в Париже в июне? Какие у Вас планы? Я пишу Вам такие вопросы заблаговременно, мне хотелось бы твердо знать, что я с Вами наконец встречусь.

Грета мне пишет, что видела Вас. У нее видимо был большой успех на выставке. ${ }^{275}$ Как я за нее рада! Я надеюсь будущим летом увидеть и ее. И вобще я так волнуюсь при мысли о поездке в Европу, что ни о чем думать не могу, как только о ней.

Я подготовила к печати том стихов Ходасевича, была занята редактированием их: комментарии, био, библио и пр. Надеюсь выпустить в 1960 году. ${ }^{276}$ Кроме того, набежали дела: темы экзаменов по русскому языку, кот. мне поручили делать (на всю Америку, стандартные), а теперь разговор идет (с начальником славянского департамента) об учебнике для второго курса. Читаю лекции по литературе, а в будущем году как будто бы получу звание (ассистант профессора). Прочтите пожалуйста мой рассказ в Нов. Журнале, «Черная болезнь «. ${ }^{277}$ И спасибо Вам за все Ваши добрые слова о моих писаниях. Статья о Набокове (вызвавшая среди российских собратьев странное раздражение, основанное главным образом на дикой зависти к Набокову) переводится сейчас на английский. Пишу стихи. Но белые, так что Вам наверное будет не по душе. Чтобы этой самой душе не кривиться, не посылаю их Вам.

275 Greta Gerell exhibited in 1959 at the Sture Gallery in Stockholm.

276 Another year passed before the book appeared. See note 310 to Berberova's letter of 1 August 1961.

277 “Černaja bolezn',” Novyj Žurnal 58 (1959). 
Поздравляю Вас с наступающими праздниками, желаю Вам всего лучшего в новом году. И чтобы нам увидеться в милом Париже.

Жму Вашу руку. 
Милый Сергей Александрович,

Вы вероятно получили мое письмо, посланное неделю тому назад. У меня два адреса и на любой можно писать, но надо их писать правильно, а Грета все время пишет не то. Она на письмо, кот. ей вернули, смешала две губернии и выпустила город. Я ей все сегодня объяснила и надеюсь, что это в последний раз. Письмо ее было страшно интересно, хорошо, что я все-таки его в конце концов получила.

Пожалуйста, не беспокойтесь о том, доходят ли Ваши письма, пишите либо в Нью-Хейвен (который и ЕСТЬ ЙЕЛЬ) или в Нью-Йорк. Спасибо громадное за фотографии картин Греты. Они очень хороши. Вы не написали, надо ли их Вам вернуть. Я их буду хранить, пока Вы мне не напишете.

О статьях моих о Горьком скажу вот что: это были три фельетона сразу после его смерти, напечатанные у Милюкова в газете (Посл. Новости). ${ }^{278}$ У меня есть старые вырезки - один экземпляр. Я не могу рискнуть послать его Вам по почте. Если Вам они нужны, я должна дать переснять. Это сделать не очень трудно и совсем не дорого. Напишите, что мне делать. Статья (три главы) живая, но конечно, сейчас я бы так не написала. Много «сплетен« личных и вообще «легковесно«. Не для серьезного «органа«, но любопытные есть вещи: непосредственно, молодо и на других не похоже. ${ }^{279}$

Пока заканчиваю письмо. Шлю пожелания к Новому Году. Надеюсь увидеть Вас летом, твердо надеюсь. Не подкузьмите!

НБерберова

278 Pavel Miljukov (1859-1943) was editor-in-chief of the Paris newspaper Poslednie Novosti from 1921 to 1940.

279 Berberova soon sent a copy of the articles to Rittenberg. See her letter of 29 January 1960. 
29 января (1960 - judging by the postmark)

Дорогой Сергей Александрович,

спасибо за письмо и карточку к именинам. Я их давно уже не праздную, потому что перестала верить в Ангелов. Посылаю Вам фотокопию. Конечно, Вы ничего мне за нее не должны - как Вам не стыдно об этом писать. Все, что Вы пишете мне о своих делах, родных и поездке, все навсегда останется между нами, пожалуйста, не думайте, что я могу кому-либо обо всем этом рассказать. Мне всегда очень интересно читать хотя бы даже слабые Ваши намеки о том, что Вы т а м видели и что о т т у д а слышали. Пожалуй, Вы единственный из моих друзей (да много ли их вообще?), который мне рассказал столько интересного, а главное - понял все так, как поняла бы и я сама.

Мне кажется, что время бежит страшно быстро и скоро-скоро мы с Вами увидимся. Неправда ли?

Ваша

НБ Attached: Berberova's series of articles "Tri goda s Gor'kim," Poslednie Novosti 5567, 5571 och 5574 (1936), with the note "Pros'ba pri slučae vernut'. N.B." In Mosty 8 (1961) she published Chodasevič's notes about these three "Gor'kij years," with her own foreword. 
Дорогой Сергей Александрович,

Я получила и письмо Ваше и открытку. Получила также критику выставки Греты Герелль. Вообще все, что посылается - доходит, но Вы, милый друг, рассматриваете, по моему, почту как некое чудо и всегда беспокоитесь, что самое важное непременно не дойдет. Ваши письма всегда интересны, и Ваши планы меня всегда немножко волнуют, и теперь опять - эта новая поездка в Л. Когда? На долго ли?

У меня по-немногу начинают вырисовываться планы на лето и я хотела бы, чтобы Вы подумали, когда и где мы могли бы с Вами встретиться. Июнь я весь буду в Париже и самое лучшее было бы, если Вы вообще собираетесь во Францию, Вам приехать туда. Июль я проведу в Италии (Флоренция и Рим). Может быть Вас соблазняет приехать в Рим и погулять по Риму вдвоем со мной? Август у меня «занят« - я еду в Грецию с Георг. Алекс. (моим мужем) на две недели, а потом - в Венецию и в Прованс (с друзьями-американцами). 8-го сентября уходит мой пароход в США.

В Париже я, вероятно, остановлюсь у моей подруги (француженки) на 14 рю Сен-Гийом (около кафе Флор).

Теперь Вы уже получили наверное номер Нового Журнала. Не кривите душой, скажите, что думаете, о «Черной Болезни«.

Не могу писать о себе, об университетской работе и о всяких замыслах. Слишком быстро приближается лето, когда можно будет поговорить обо всем, и писать невозможно. Что с Гретой? Она не пишет мне. Ее тоже я хотела бы повидать о ч е н ь, и она писала, что приедет куда-нибудь, где мы могли бы встретиться. Боюсь, что она болеет и хиреет (но никогда не во Франции!! Только в Швеции!!). Ей было бы полезно пожить в Италии или на юге Германии летом. Напишу ей скоро, если не получу от нее письма, чтобы и ей сообщить о своих планах.

Ваша новость о переиздании Анненского в меня как громом ударила. Заказала себе, заказала и в здешнюю библиотеку. ${ }^{280}$ Через 20 лет НАС тоже будут издавать там.

280 Innokentij Annenskij, Stichotvorenija i tragedii, Leningrad 1959 (with a foreword by Andrej Fedorov). 
Милый Сергей Александрович, я вижу, что Вы беспокоитесь о поездке в Париж, потому отвечаю сейчас же, простите за краткость. Я буду в Париже между пятым и тридцатым ИЮНЯ. Я еще не знаю, где остановлюсь. Возможно, что в Отель де ля Президанс (рю Пантиэвр, около Елис. Полей). Возможно, что у моей подруги. Я напишу Вам в середине мая точный адрес и телефон. Имейте ввиду, что Президанс недорогое и приличное (и центральное) место. 3 доллара в день комната (без ванны) и брекфест, есть где вымыться - т.е. принять ванну. И никто не удивляется, если Вы выражаете желание вымыться.

Черкните мне о своих намерениях, я во всяком случае черкну Вам о себе около 15-го мая.

Привет.

НБерберова

А Грета не приедет? Какое огорчение! Неужели она ТАК плоха? 
14 мая (1960)

Милый Сергей Александрович,

всего несколько слов, чтобы сказать Вам, что я приезжаю в Париж 2-3 июня и 4-го утром очень бы хотела, чтобы Вы позвонили мне, если уже будете в Париже, в отель де ля Президанс, на рю Пантиэвр. Я там пробуду некоторое время, потому что может случиться, что около 10го июня я перееду из отеля в пустую квартиру моей подруги. Если 4-го утром Вы не позвоните мне, то имейте в виду, что моя кузина всегда будет знать, где я нахожусь. Ее адрес: 7 рю де Жак Мавас, а телефон: ЛЕКУРБ 54-17. Она о Вас знает. Ее зовут Ася Рубеновна.

Радуюсь, когда думаю, что увижу Вас в чудном Париже. Жму руку. Грета пишет, что будет в Париже 12-го.

НБ.

Hotel de la Présidence

Rue de Penthièvre

Paris 8 .

Mme Kochevitsky (о чем передайте пожалуйста и Грете. Другой фамилии не будет) 
Дорогой Сергей Александрович, получила Ваше письмо из Стокгольма; не понимаю: получили ли Вы мое, посланное 13-го мая? Я писала Вам, что буду в Париже 2-3-го июня и прошу Вас 4-го позвонить мне (или придти) в Отель de la Présidence, rue Penthièvre. (Я всюду - Кочевицкая только!!)

Теперь думаю: приходите лучше, а не звоните, и не очень поздно по возможности, часов в 10 утра, я встаю рано и надеюсь, что Вы тоже. Мы с Вами позавтракаем, проведем время вместе - как захочется. Очень радуюсь встрече. Выезжаю послезавтра. 4-ое число будет суббота. Если Вас тянет куда-ниб. в театр, возьмите веч. билет и для меня (только не «бульвар«, а что-нибудь авангардное). Впрочем, как хотите! Днем мож. быть сходим на выставку? Не пугайтесь, я Вас не «замотаю« - дам и отдохнуть.

Ваш друг 
Милый Гуля, я не могу найти слов, чтобы выразить волнение, которое охватило меня вчера при чтении Вашего письма. Спасибо Вам, дорогой друг, за Ваши строки. Во первых, от Вас впервые я узнала, что папа мой пережил маму. Вот короткие данные о них, которые могут Вам пригодиться, если Вы опять встретите когда-нибудь Эсю: я переписывалась с ними до 1941 года. Я знаю достоверно, что в сентябре 1941 года они оба были живы. Потом началась блокада Петербурга и страшная зима (см. Ленинградский дневник Веры Инбер ${ }^{281}$ ) - после этого - ничего. Я полагала всегда, что они оба не пережили той зимы. Теперь я не знаю, что думать. Умоляю Вас, если Вы увидите Эсю, спросите КОГДА умерла мама и КОГДА папа и все, что она (или другая подруга) знает о их последних годах (месяцах? днях?). Фамилию другой подруги, кот. видимо Вы знаете, я бы хотела знать. Возможно ли это? Фамилию Эси ${ }^{282}$ и Иды ${ }^{283}$ Вы тоже не пишете. Как я понимаю Вашу осторожность! Если Вы не можете написать их мне сейчас, то может быть сообщите в другой раз. С Эсей я была дружна в гимназии, но потом мы разошлись. Ида - настоящий друг, с кот. до сих пор у меня есть общее, и какое общее! Она конечно ближе. Я хотела бы ей послать что-нибудь. Это вероятно невозможно. Первый муж Иды мне известен, это - М. Ф. ${ }^{284}$ Второй видимо тоже литератор. ${ }^{285}$ Есть ли дети? ${ }^{286}$ Неужели Фрида умерла потому что так любила отца?287 Это кажется мне невероятным. Какой была ее судьба? Чувствую, что забрасываю Вас вопросами, но не могу удержаться. Ваши строки об Ахматовой я перечла десять раз, и вообще все письмо со вчерашнего дня перечитываю все время. Примите мое самое искреннее соболезнование по поводу смерти Вашей сестры. (Это жена Коли? Или по другому с ним свойственники?) Все, что Вы мне пишете, я храню в абсолютной тайне. Да и кому рассказывать? Даже Г.А. (моему мужу) я не говорю о том, что Вы пишете - люди для него чужие, зачем лишнего человека посвящать во все эти детали? Сказала только общее, а имена ему ничего не говорят. Так что можете быть спокойны.

281 Vera Inber, Počti tri goda. Leningradskij dnevnik, Leningrad 1945.

282 Ėsfir' Kolodina.

283 Ida Nappel'baum. See note 271 to Berberova's letter of 1 September 1959.

284 Michail Froman. See note 270 to Berberova's letter of 1 September 1959.

285 The writer Innokentij Bakalaev (1898-1964) became Nappel'baum's third husband.

286 The daughter Ekaterina Carenkova (née Froman, b. 1932) is today living in Hamburg.

287 Frida Nappel'baum (see note 273 to Berberova's letter of 1 September 1959) died of a stroke on the day of her father's death. 
О Вашем несчастном случае знаю от Греты и из Вашей открытки. Надеюсь, что Вы получили страховые. Прошли ли боли? Делаете ли массаж? Работаете ли по прежнему? Я в переписке с двумя русскими спецами - один американо-итальянец из Гарварда - Ренато Поджоли, только что выпустивший книгу о русских поэтах-символистах (по англ.). ${ }^{288}$ Другой - знаменитый Морис Баура из Оксфорда. ${ }^{289}$ Переводчик русских поэтов на англ. и автор многих книг о русской поэзии. Эти книги, между прочим, Вам были бы интересны, если Вы разбираете по англ.

Обнимаю Вас, дорогой Гуля, и спасибо еще раз.

Нина

Посылаю Вам подарок - фото. Всех копий 24 и они нумерованы.

288 Renato Poggioli (1907-1963), Italian literary scholar living in the United States, author of The Poets of Russia, 1890-1930, Harvard 1960.

289 Cecil Maurice Bowra (1898-1971), professor at Oxford University, prominent expert on Russian modernist poetry. 
New Haven, Conn.

U.S.A.

29 ноября 1960

Дорогой Сергей Александрович,

вчера получила Ваше письмо и спешо Вам написать, что напрасно Вы думаете, что Нора Л. написала свою корреспонденцию на основании Вашего рассказа - к А. ${ }^{290}$ Ходит много приезжих, и в частности я имею основание полагать, что Л. написала все после того, как видела одного человека, который был у А. в начале сентября. Они говорили на многие темы, А. спрашивала, как понравилась за границей ее поэма, ругала Г. Иванова за «Петербургские зимы«, ${ }^{291}$ призналась, что не любит «Живаго« и пр. и пр. и пр. Так что не думайте, что Вы в чем-либо погрешили против тайны - все это далеко не тайна, к ней ездят в Комарово и ходят в ее ленинградскую квартиру иностранцы и русские эмигранты, которые бывают в России. Пожалуйста, перестаньте грызть себя. В этом ничего нет такого, за что Вы могли бы себя упрекнуть.

Пишу это, чтобы кстати Вам сказать, что третьего дня я видела еще одного «путешественника«, который был у Ахм. и конечно собирается обнародовать итоги своего визита. Только не знаю, на каком языке.

Пока не пишу длинного письма. Надеюсь написать опять вскоре. Я рада, что мука Ваша прошла и что Вы возобновили нормальную жизнь. Будьте здоровы, не волнуйтесь о чем волноваться не следует. Не забывайте меня.

Нина

290 Nora Lidarceva (pseud. of Nora Sachar (1899 (1900?)-1983), "Poslednie svedenija ob Anne Achmatovoj," Russkaja mysl', 4 August 1960.

291 Georgij Ivanov's very high-handed memoirs (1928, expanded edition 1952). 


\section{BTOPOE}

29 ноября 1960

Дорогой Гуля, письмо, которое Вы уже прочли, я написала на тот случай, если бы кто-нибудь Вас упрекнул в содеянном. Все мы делаем глупости, забудьте Лид. И вычеркните ее из числа друзей, которым можно доверять. Сделайте из моего письма то употребление, которое найдете нужным. В нем все правда, но НЕ ВСЯ правда. А это письмо, которое теперь читаете, выбросьте, чтобы оно не попалось потомству.

Вы всегда можете сказать, что Лид. писала не с Ваших слов, потому, что Лид. писала НЕ ТОЛЬКО с Ваших слов. Я прошу Вас только вот о чем: вышлите мне сейчас же ее фельетон, кот. я Вам сейчас же обещаю отослать обратно.

Эренбурга я читала, и Любимова (в сентябрьской книжке тоже). ${ }^{292}$ Прочтите Любимова. Можно понять, что ВСЕ МЫ будем постепенно реабилитированы, ибо он намекает, что мы все - некий «патримуан «293 и несмотря на иностранные паспорта - русские писатели, принадлежащие России.

Между прочим, с моим знакомым Ах. говорила и о смерти Глебовой Судейкиной. ${ }^{294}$ Лишнее подтверждение, что я вам пишу правду.

Я страшно занята. Напишу Вам на праздниках, когда у меня будет больше времени. Работаю не только для университета, но и для себя. У меня в голове несколько статей (литературных), и начала я книгу, громаднейшую, даю себе два года сроку для нее.

Берегите себя, не поддавайтесь меланхолии, помните, что у Вас есть друзья, которые Вас нежно любят.

Нина

292 Excerpts from Il'ja Ėrenburg's Ljudi, gody, žizn' were published in Novyj mir 8 and 9 (1960). The August issue 8 also contained Lev Ljubimov's (1902-1976) “Dvenadcat' let spustja."

293 patrie moins $($ French $)=$ lesser fatherland.

294 The legendary actress Ol'ga Glebova-Sudejkina, b. 1885, a central figure in Achmatova's Poema bez geroja, died in Paris in 1945. 
Милый Гуля,

пишу сегодня кратко, потому что я сегодня должна написать дюжину писем - куча лежит на столе, - на которые не отвечено, - ни пройти, ни проехать.

Отсылаю вырезки. Ничего страшного в ней не усмотрела. Как я уже писала Вам, это же самое мог рассказать Н.Л. ${ }^{295}$ и другой человек. Ваше письмо я получила, и вообще не беспокойтесь никогда о своих письмах - они все отлично доходят. В статейке Н.Л. нет ничего, что конкретно указывало бы на Вас.

Как Вы чувствуете себя? Многое хотелось бы Вам рассказать, особенно в связи с тем, что я теперь пишу, и даже показать кое-что, но придется ждать до встречи.

Стихи Ходасевича готовы (манускрипт) и я хлопочу об издании. Все как будто устроится к весне.

Новые стихи Ахматовой, о кот. Вы пишете (есть замечательные, но кажется не все), перепечатаны в Новом Русском Слове, так что они дошли до меня. ${ }^{296}$

Вы читаете Гонкура, а я читаю Генри Джеймса. ${ }^{297}$

Простите, что такое сумбурное письмо. Жму Вашу руку.

295 See note 290 to Berberova's letter of 29 November 1960.

296 Novoe Russkoe Slovo, 6 and 27 November and 11 December 1960.

297 It was in this same year that Berberova published "Pjatnadcat' pisem I.S. Turgeneva k Genri Džejmsu," a commentary to Turgenev and Henry James's correspondence in Mosty 7. 
(1961?)

Спасибо за открытку, дорогой Гуля, очень была тронута. Надеюсь, Вы здоровы. Что-то давно не было письма. Какие планы?

Ваша

Нина 
Милый друг Гуля, спасибо за письмо и за тонкий, умный и справедливый разбор моей статьи. Сегодня получила и сегодня пишу Вам. «Черную тень « убрала немедленно и Белинского оставила без эпитета. ${ }^{298}$ Вы совершенно правы: и Недоброво, ${ }^{299}$ и Гершензон ${ }^{300}$ и Никольский ${ }^{301}$ несправедливо забыты. Согласна с Вами, что импрессионист-критик может стать художником. Это бывает редко. Об Адамовиче скажу, что чем больше живу, тем меньше его люблю. В своей статье о Ржевском (в Нью-Йоркской газете) он сказал, что он хочет Ржевскому за его книгу «пожать руку«. ${ }^{302}$ Другому он захочет «пожать ногу« - что же это будет? Какое это имеет отношение к ВЕЩИ?

Верно очень, что нынешняя сов. критика ушла далеко от социального метода. Об этом напишу и даже процитирую Ваше письмо, если позволите. Сейчас начинаю думать о второй статье. Только ее пришлю Вам не тогда, когда она будет в наборе, а когда она будет готова - чтобы я могла воспользоваться некоторыми Вашими советами и возражениями.

Гуковский для меня все же формалист. ${ }^{303}$ Все его прошлое связано с этим направлением. Потому он и хорош, и «питателен«.

Теперь скажу о критике Вашего друга моего разбора «Незнакомки«. «Котелки« не «орут« внутри ресторана, внутри ресторана неизвестно кто орет. Котелки, - так я понимаю - только гуляют. Однако, это замечание ценное, очень интересное. Я все-таки думаю, что первое впечатление, что орут интеллигенты. Не понимаю, почему это так. Может быть, я не права. ${ }^{304}$

Возможность антитезы, как Вы пишете, насчет «солнца« мне приходила в голову. Я не хочу ее. Мое восприятие отказывается принять ее. Если ее принять даже только как возможность (неразвитую), то она тоже все подавит. Поэтому я и беру солнце, как пьяный бред.

298 Berberova's article "Ključi k nastojaščemu." See note 309 to Berberova’s letter of 1 August 1961.

299 Nikolaj Nedobrovo (1882-1919), poet and critic close to Achmatova.

300 Michail Geršenzon (1869-1925), literary and culture historian.

301 Jurij Nikol'skij (1893-1922), promising young literary scholar, died of typhus in a Bolshevik prison.

302 Adamovič's review of Leonid Rževskij's "Dvoe na kamne” in Novoe Russkoe Slovo, 2 April 1961.

303 Georgij Gukovskij (1902-1950), literary scholar, professor at Leningrad University.

304 See Alexandre Blok et son temps (Paris 1947), 81 ff. (Aleksandr Blok i ego vremja. Biografija (Moscow 1999), 96 ff.). 
Что касается шелков, то их больше нет и не будет - во всяком случае, на ближайшие пятьдесят лет. Так что для меня они чудесный анахронизм. В общем-же, дорогой Гуля, мне было страшно важно Ваше письмо. Пока ничего Вам больше не пишу. Дел у меня много, конец года. Надеюсь, в июне написать новую статью (там будет о соц.-символизме - мое открытие), и прислать Вам.

У Греты был успех в Париже и она счастлива. ${ }^{305}$ Как я рада за нее. Привет.

Нина

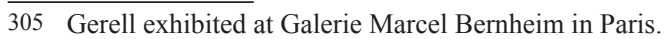


Дорогой Гуля, не проходит дня, чтобы я не думала о Вас: по моим рассчетам Вы вот-вот вернетесь в Швецию, и я могу каждый день ждать от Вас письма. Не могу сказать Вам, с каким волнением я его жду. Увидите ли Вы Эсю, или Иду, или еще кого-нибудь?? Каждое Ваше слово будет для меня ценным.

Итак, Вы были в Венеции, чудной, божественной Венеции, которую я так люблю, как ничего на свете. В будущем году мы опять увидимся с Вами. Я приеду в Париж, поеду в Италию, буду (по делам) в Германии. Мы можем съехаться и в Париже, и в Мюнхене, и в Венеции. Где Вы остановились там? Я жила в меблированных комнатах около почты, но было дорого (т.е. дорого за обыкновенные комнаты, это был даже не отель, а платила я, как в отеле) и не очень удобно. Знаете ли Вы Санта Эллену? Это место между Джардини Публичи и Лидо, от Джардини Публичи можно идти пешком. Это - рай, но там жить нельзя, нет отелей. Боже, как я там наслаждалась - в последний день перед отъездом. Вещи мои были уже на вокзале, я поехала туда, гуляла, завтракала, «открыла« это неизвестное никому, кажется, место, и клялась себе, что опять приеду поклониться ему.

Я работаю на летнем семестре. Платят хорошо, работы не много, всего 3 часа в день. Днем езжу купаться, а вечерами работаю. Пишу вторую статью для Нового Журнала на литературные темы - пошлю Вам копию, когда будет готово, затем у меня здесь публичный доклад (по английски) о новой сов. литературе. Затем, в два дня написала свою автобиографию - для испанского издания моих повестей. Хочу Вам тоже прислать, чтобы Вы узнали обо мне то, чего не знаете.

Напишите мне, Гуля, пожалуйста, о многих вещах: о планах, о поездке в Россию, о Грете, от кот. давно нет писем, о настроении. Помните, милый Гуля, что мы друзья с Вами и мне все интересно знать. Представьте, какая странность: после того, как я в прошлом году увидела моих старых друзей, я с очень многими постепенно как-то прекратила переписку, а вот с Вами чувствую гораздо более интенсивную связь, чем прежде.

Жму Вашу руку и шлю привет. 
Дорогой Гуля, вчера пришло Ваше письмо. Спасибо. Теперь я знаю, что мои родители умерли, эвакуированные из Ленинграда... Что это меняет? Не знаю, трудно сказать, но до сих пор всего страшнее было мне думать о них в Ленинграде 1942 года (помните, Инбер писала о нем? $\left.{ }^{306}\right)$. Это все было 20 лет тому назад, и все таки.... как это волнует!

Я теперь буду ждать нашего свидания (через год) когда Вы мне расскажете подробно о своей жизни в Лен. и о Ваших близких. Вот видите, как хорошо, что Вы поехали (3 года тому назад?), а Вы сомневались. Теперь Вы там, как у себя дома.

Гуля, я - несмотря на страшную жару и в общем порядочную усталость - работаю, как вол. 20-го конец. Написала свою автобиографию для испанского издания повестей - хочу, чтобы Вы прочли ее, она помоему интересная. Но сейчас ее не посылаю, а посылаю новую статью: «Ключи к настоящему«. Прошу Вас, дорогой, прочтите ее внимательно (иначе, я знаю, Вы читать не будете), сделайте замечания на полях и ВЕРНИТЕ мне ее, потому что это единственная копия - оригинал пойдет Гулю в Нов. Журн., как только Вы вернете копию с поправками. Напишите, не кажется ли она Вам удачнее чем Великий Век? ${ }^{307}$ Надо Вам сказать, что я получила после напечатания Великого Века довольно много восторженных похвал - в том числе, от американских профессоров-славистов, и от.... вдовы Троцкого, которой 89 лет!!! 308

Мне самой «Ключи« кажутся статьей менее «трудной«, более доступной, и более «близкой« русскому читателю. Буду ждать с нетерпением Вашего суждения. ${ }^{309}$

20-го конец летнего семестра. Поеду в Нью-Йорк, а там посмотрю, что буду делать. У меня огромная радость: книга Ходасевича вышла, получила по воздуху первый экземпляр, выглядит ЧУДНО. Вам пошлю, как только получу настоящую порцию - не раньше сентября, плывет все это страшно долго. Я горжусь, что устроила все это: отредактировала,

306 See note 282 to Berberova's letter of 29 October 1960.

307 Berberova's story "Velikij Vek" appeared in Novyj Žurnal 64 (1961).

308 Trockij's widow Natal'ja Sedova (1882-1962). Thus at this particular time she was not 89 but 79 .

309 Berberova's article "Ključi k nastojaščemu" dealing with Socialist Realism and recent literature appeared in Novyj Žurnal 66 (1961). 
издала, истратила много денег, но по крайней мере у него теперь такая книга, какой нет ни у Белого, ни у Кузмина, ни у многих других. ${ }^{310}$ Милый друг, обнимаю Вас. Позвоните Грете и скажите, что я СТРАШНО беспокоюсь о ней, ибо ни на письмо мое, ни на открытку она не ответила. Не больна ли? Три месяца от нее ни слова не было - это необычно.

\section{Ваша}

Нина

Пишите до 20-го - сюда, а потом, до 15 сент. - Kochevitsky. 101 West 78 Street. Apt. 73. New York 24. N. Y.

310 Vladislav Chodasevič, Sobranie stichov (1913-1939), edited and with a foreword by N. B(erberova), Munich 1961. In Rittenberg's archive there is a copy with the dedication "Gule s ljubov'ju i vernost'ju. Nina. 1961". 
Дорогой Гуля, спасибо за письмо, статью получила (напрасно Вы беспокоились посылать ее заказным) и Никитина убрала в угоду Вам. Сегодня первый день моей свободы, вчера кончились занятия на летнем семестре. Еду в Нью-Йорк, где накопились всякие дела, и в середине следующей недели решила вернуться и тихо сидеть здесь 10 дней и переводить Элиота. Затем 1-го поеду в Н.-Й. на две недели, развлечься немножко, и 15 сент. Буду обратно - начало занятий.

Устала. Было очень жарко. И я много работала, главное - дома, но и в университете было утомительно. Думаю, что мне не следует больше летом работать - можно прожить и без этого.

Ваше письмо доставило мне радость; да, Вы теперь ездите с такой легкостью в Ленинград, что даже удивительно. О театрах Вы мне написали, но мне особенно интересно было бы узнать о «петербургских экзистенциалистах«, о разговоре с «молодым литератором из рабочих« и т.д. Кстати, об экзистенциалистах - видя, до чего они довели французскую литературу, я начинаю думать, что экзистенциализм - ужасная вещь, ведет к соц. реализму в конечном счете, и к распаду искусства. Недаром Сартра сравнивают с Вольтером. Но это конечно не касается экз-ма Ясперса и Гейдеггера.

У меня появилась еще очень робкая мечта: может быть через год хлопотать о «премии« или «стипендии«, чтобы год сидеть где-нибудь и переводить Элиота. Пока все это очень туманно. Если в Европе все будет в равновесии, то в июне будущего года я приеду. И мы увидимся. Очень это будет приятно.

Хочу не слишком форсировать себя насчет работы в наступающем учебном году. Сейчас набросала вводную лекцию о поэзии (курс с аспирантами) и думаю, что в конце концов из этого тоже можно бы сделать интересную статью. Но я хочу себя немножко сдержать - не писать, не работать так усиленно, как в только что прошедшем году. Ни на что другое не остается сил.

15 сент., между прочим, пойду на Ленингр. балет. По фотографиям ничего хорошего от него не жду, но стараюсь не быть предубежденной. $\mathrm{B}$ театре, как и в пианистическом исполнении (как и в поэзии), ТАМ ничего не преображено.

Гуля, я страшно беспокоюсь о Грете: с апреля не было писем, на мои 2 письма и 1 открытку (на Хеммаре) ответа не было. Что это значит? 
Никогда этого не было. Если у нее опять никто не ответит, позвоните ее сестре Наде Герелль на Свеавеген и скажите, что я так больше не могу. Привет, дорогой Гуля. 
30 августа 1961

Милый Гуля, пишу наскоро, чтобы, чтобы сказать, что я получила и открытку Вашу, и письмо. Письмо страшно интересное. Спасибо. Послезавтра еду на 2 нед. в Нью-Йорк, а потом вернусь и засяду здесь до Рождества. Все закончила: «Ключи к настоящему« (статья, кот. была у Вас) сдала в Нов. Журнал. Пришлю Вам для прочтения краткую автобиографию (а настоящую - пишу). Все доходит. Не надо посылать заказным. Автобиогр. конечно посылайте обратно не по воздуху. Я сейчас перевожу Элиота. Перевела 4 больших поэмы. Интересно, но трудно. ${ }^{311}$ Мечтаю увидеться в июне-июле.

Вводная лекция пока не написана, я или ее напишу всю целиком и пошлю Вам, или если хотите, пошлю Вам конспект.

Жму Вашу руку, милый друг.

НБ

Греты письмо конечно получила в Нью-Йорке!!

311 See note 328 to Berberova's letter of 27 May 1962. 
Милый Гуля, пишу несколько строк только, так как занята по горло и откладываю длинное письмо до другого раза. Все получила: письмо Ваше и рукопись. Надеюсь, что Вы получили теперь книгу Ходасевича, которую я Вам послала в середине сентября. Неужели Вы могли подумать, что я не пошлю ее Вам в подарок, скептический Вы человек, и что Вы будете ее и п о к у п а т ь? За кого Вы меня принимаете?

Я погрузилась в фон Додерера - венский писатель, автор романа «Бесы«, только что переведен на английский и гремит. Интересная, но не совершенная вещь. ${ }^{312}$ Хочу восстановить немецкий язык, чтобы читать Музиля и Броха ${ }^{313}$ - все венцы.

Где мы встретимся и когда? У меня уже есть билет на «Франс« (новый дивный пароход) на 25 мая. Поеду прямо в Лондон, на неделю, оттуда в Париж, потом в Испанию, потом в Мюнхен (около 5-го июля) дней на пять. Ах, как об этом приятно думать.

Ваша

Нина

Вечером: сейчас получила Ваше письмо. Ходасевича я послала не по «вашей просьбе«, а полтора месяца тому назад - Вам в подарок. Грете напишу на днях. Н.

312 In "fon Doderer i ego romany" (Novyj Žurnal 67 (1961)) Berberova wrote about Heimito von Doderer's (1896-1966) ties to Russia. His Die Dämonen. Nach der Chronik des Sektionsrates Geyrenhoff originally appeared in Munich in 1956.

313 Hermann Broch (1886-1951). 
Милый Гуля, Вы меня спрашиваете, читала ли я «Лолиту«, забыв что я о ней написала большую статью в «Нов. Журнале« 3 года тому назад. Получила Ваши письма, спасибо. От Греты тоже было - с трудом написанное. Бедная она, какая с ней стряслась беда!

Я сейчас не могу сосредоточиться, чтобы написать Вам длинное и интересное письмо - столько дел надо закончить перед праздниками. Обо всем в подробностях расскажу при встрече: тут и архив мой, который переводится в библиотеку, и «консультантство« при одной комиссии (учебник русского), и собственные писания для «Нового Журнала«, и «Мосты« (редакторство), и перевод Элиота, и чего тут только нет! Кручусь целый день от одного письменного стола (в моем кабинете в университете) к другому письменному столу (дома). Сегодня нас засыпало снегом.

Я не понимаю, почему Кленовский посылает Вам все время какие то глупости и гадости, которые пишутся о людях (в том числе о Блоке, обо мне и др.). Кому это интересно? И, кстати, не читала статью, где меня кажется кто-то ругал в здешней (Нью-Йоркской) газете. И вообще перестала вовсе читать критику нашу - мне стыдно за нее. Почему Вы не поняли «Кларку-террористку« - я тоже не поняла. Ваши письма стали какие то загадочные. Бродского читала очень давно - его книга о Пушкине, видимо, только что дошла до Вас? ${ }^{314}$ Книга Набокова о Гоголе считается классической здесь - все студенты ее носят при себе в кармане и обожают. Она разошлась в дешевом издании в сотне тысяч экземпляров и Гоголя знают ВСЕ благодаря Набокову. ${ }^{315}$ Что касается «Хирошима мой друг«, то это такой фильм, которого вообще кажется не было - это гениальная вещь, не пропустите ее. Ничего пошлого в названии не вижу - оно символично, как всякий хороший кинематограф, и значит больше, чем Вам кажется. ${ }^{316}$

Вот, милый Гуля, какой у нас пошел спор. Пока кончаю письмо, спешу. Поздравляю Вас с праздниками, будьте благополучны в новом году.

Нина

314 Nikolaj Brodskij (1881-1951), A.S. Puškin. Biografija, Moskva 1937.

315 Vladimir Nabokov, Nikolai Gogol. The Makers of Modern Literature, Norfolk, Conn., 1944.

316 Based on a manuscript by Marguerite Duras, Alain Resnais' film Hiroshima Mon Amour (1959) was important in the emerging New Wave in France. 
16 января 1962

Милый Гуля, все Ваши письма получила, но так занята, что мне трудно написать Вам длинное интересное письмо - из того сорта, какой Вы любите. Отвечаю на Ваши сомнения насчет нашей встречи в Париже: я буду там от 7-го до 20-го июня, и если Вы не сможете приехать, то мы можем увидеться гораздо позже в Италии. Я 20 июня поеду на 2 недели в Испанию (в первый раз в жизни), а оттуда в Сицилию, где засяду в тихом месте на месяц писать свою книгу. Начиная с 10 августа я опять появлюсь на горизонте, буду где-нибудь между Перуджией и Венецией. В конце августа буду в Мюнхене. М.б. приедете в Германию? До того времени много, мы еще много раз напишем друг другу. 8-го сентября поеду обратно в Америку.

Не могу сейчас читать о Толстом, но обязательно прочту Вашу любимую книгу. Сейчас ни о чем не могу думать, только о своем курсе - завтра начинаю символизм, только что закончила Соловьева, Григорьева ${ }^{317}$ и Случевского. ${ }^{318}$

Новый журнал вышел, № 66. Там моя статья, кот. Вы знаете, ${ }^{319}$ и прекрасная (по-моему) статья Вейдле о Ходасевиче - не о ВСЕМ Ходасевиче, но о части его. ${ }^{320}$ Напишите, когда прочтете, что Вы думаете о ней.

Позвоните Грете. Скажите, что я думаю о ней много и люблю ее, и мечтаю увидеться летом, но писать не в силах сейчас. Пусть простит меня за молчание.

Будьте здоровы, Гуля, дорогой мой друг, Ваша

Нина

317 Apollon Grigor'ev (1822-1864).

318 Konstantin Slučevskij (1837-1904), poet, precursor of the Symbolists.

319 "Ključi k nastojaščemu."

320 Vladimir Vejdle wrote about Chodasevič on the occasion of his 75th birthday in "Chodasevič izdali - vblizi” (Novyj Žurnal 66 (1961)). 
20 марта 1962

Милый, дорогой Гуля, Вы молчите так долго, что я, часто думая о Вас, начинаю беспокоиться. Здоровы ли Вы? Где Вы? Какие планы? Хотелось бы задать Вам много вопросов, но сейчас хочу написать Вам о себе.

Все это время я была нечеловечески занята. Между тем писать (книгу) мне страшно хочется, и я вижу, что зимой этого делать нельзя - можно переписывать, можно отделывать, но не писать. И вот я решила в Европу в этом году не ехать. Прямо скажу: мне вдруг стало ясно, что я должна сесть с 1-го июня и писать. Может быть, два месяца - не отходя от стола. В голове все бурлит мыслями и даже строчками, и я только об одном и думаю: как мне дорваться наконец до свободных дней (1-го июня) и положить на стол кучу бумаги. ГДЕ это будет - мне решительно все равно - только бы не двигаться с места, и никого не видеть. А планы на Европу были все «разработаны« - с Испанией, Италией, Францией и даже Мюнхеном - по делам. Так что в этом году не увижусь с Вами, но в будущем году - абсолютно непременно, потому что в будущем году будет совсем другое настроение.

Книга Ходасевича идет хорошо, и все меня за нее хвалят. Я счастлива, что, видимо, через год она вся будет распродана. Большой успех для книжки стихов! А здесь в университете - идут мои курсы, к которым готовлюсь тщательно. В курсе поэзии теперь дошла до Белого. А потом будет Маяковский и Пастернак. Перечитала Маяковского - и опять, и опять думаю, что это был ужас, ни одного слова для меня нет в нем - только грохот и тарахтение. И Пастернаком разочарована, главное что он, наперекор утверждению Валери, ${ }^{321}$ пошел «обратным « путем, начал с «Пьяного корабля« ${ }^{322}$, а кончил «Озером« Ламартина. ${ }^{323}$

От Греты ни слова. Что она? Здорова ли? Как ее рука? Хочу написать ей. Как Ваши лекции? Как самочувствие? Едете ли к сестре?

Черкните хоть два слова, чтобы я знала, что Вы существуете. Жму Вашу руку.

Нина

321 Paul Valéry (1871-1945), French poet, essayist and philosopher, inspired by Stéphane Mallarmé.

322 Arthur Rimbaud's famous poem "Le bateau ivre" (1871).

323 Alphonse de Lamartine's (1790-1869) poem "Le lac" (1820). 
Дорогой Гуля, я так давно не отвечала на Ваши милые два письма. Раньше Вы мне прощали молчание, а теперь видно стали ко мне строже и сами не пишете. Хотелось бы знать, как Вы себя чувствуете, как живете, какие у Вас планы на лето. Едете ли в Питер, увидите ли Иду? 324 Я после долгих колебаний, как уще писала, в Европу решила не ехать, - соображения были всякие, и важные и неважные. Лето мое будет несколько авантюрным: 10 июня выезжаю в Колорадо на машине, с двумя друзьями, где месяц мы будем жить в Скалистых горах (см. Купера, ${ }^{325}$ Майн-Рида, ${ }^{326}$ Эдгара По и др.). После этого я полечу в Индиану, в тамошний университет, где буду читать лекции по русской литературе - почетно и денег порядочно. 10 августа я вероятно поеду к Тихому океану, кот. еще не видела (да и он меня не видел). Если Вам захочется мне написать, то черкните мне в Индиану (от 14 июля до 10 авг.) по след. адресу:

Prof. N. Berberova. Slavic Department. Ballantine 502. Indiana University. Bloomington, Indiana.

Адреса в Колорадо не знаю, и даже не знаю, будет ли таковой...

От Греты получила письмо и сегодня ей напишу. Почему у Вас обида на Ржевских? Что они с Вами сделали? Напишите непременно, ведь Вы дружили с ними и мне жаль, что эти люди, с кот. Вам было приятно, теперь от Вас отошли. Гуля, мне немножко беспокойно почему-то и я думаю о Вас. Здоровы ли Вы? Не слишком ли мрачны?

Здесь закончила год, прошли экзамены, много за этот год потрудилась, а теперь хочу отдохнуть и посмотреть на природу. Пишу довольно много (пьеса будет в Мостах, ${ }^{327}$ переводы Элиота в Нов. Журнале, ${ }^{328}$ не говоря уже о большой вещи, кот. пишется медленно, но все-таки пишется - четверть готова $\left.{ }^{329}\right)$. Если Вы напишите в Нью-Йорк (101. Вест 88 ул.) то до меня Ваше письмо дойдет. Обнимаю Вас, мой дружок.

Нина

324 See note 271 to Berberova's letter of 1 September 1959.

325 James Fenimore Cooper (1789-1851), first major American novelist, author of The Last of the Mohicans.

326 Thomas Mayne Reid (1818-1883), Scots-Irish American author of adventure novels.

327 "Malen'kaja devočka," Mosty 9 (1962).

328 Five poems by T.S. Eliot in Novyj Žurnal 68 (1962).

329 She is still secretive about the writing of her memoirs. 
Дорогой Гуля, Ваши письма за все эти годы, после поездки в Сов. Союз, каждый раз волнуют меня. Никто не умеет так в нескольких словах передать то, что видел - не снаружи, а изнутри. Все было, видимо, так, как Вы хотели. Повидали ААА. ${ }^{330}$ И даже записали ее голос! ${ }^{331}$ Как это замечательно. Как мне бы хотелось посидеть с Вами под деревьями Люксембургского сада и послушать Ваши рассказы, Ваши впечатления, прогнозы.... Теперь в нескольких словах скажу о себе, а то Вы давно уже ничего обо мне не слышали.

Я провела месяц высоко в горах Колорадо, где нет ни электричества, ни почтового отделения, где два раза в июне шел снеги где величественные горы и вообще весь изумительный пейсаж напоминают Доломиты. Ела форели из речки и увидела Америку совсем непохожую на все, что знала до сих пор. И какие люди! После этого полетела в Индиану, где сказочный университет (30.000 студентов), где русский факультет растет, как Гвидон, ${ }^{332}$ и где я почувствовала себя очень близко от СССР - ибо все всё время ездят туда - экскурсии, обмен, конгрессы и т.д. Там я имела большой успех, студенты у меня были замечательные. Предложили мне делить мое время между Йелем и Индианой, но я отказалась ибо все меньше люблю цыганскую жизнь. На лето будущее тоже пригласили (пятый год русского языка, т.е. абсолютно владеющие языком студенты) читать лекции по поэзии и поэтике и по технике поэтического перевода. Мои статьи в Нов. Журн. и переводы из Элиота сделали меня весьма здесь популярной. Но довольно хвастать. Купила я себе автомобиль и покатила на нем домой, храбро сделала 1400 миль. Теперь, побыв 2 дня в Нью-Хейвене, еду на 2 недели на берег моря к Георг. Алекс., который меня ждет.

О том, что я пишу и что читаю напишу в следующий раз. Сейчас только скажу Вам, что появился огромный писатель Лоренс Даррелл (англичанин) - он переводится на все языки, ему сейчас под 50.333 Прочитайте его «Александрия квартет« - такого я не читала со времени Пруста. Кое в чем он даже еще выше и больше. Я не помню, чтобы

330 Anna Andreevna Achmatova.

331 Rittenberg's traveling companion, university librarian Erik Mesterton (1903-2004), recorded Achmatova reading some of her poems, among which "Lotova žena." His recording was eventually published.

332 Tsar Saltan's son Gvidon, who becomes a bogatyr with magical powers in Puškin's narrative poem Skazka o care Saltane (1832).

333 Lawrence Durrell (1912-1990), English writer, author of the very popular novel The Alexandria Quartet (1957-1960). 
когда-либо за последние 30 лет «беллетристика« производила на меня такое впечатление. Я раздавлена и вознесена.

Обнимаю Вас, дорогой мой друг.

Нина 
17 октября 1962

Дорогой Гуля, я не понимаю, почему Вы не пишете мне. Я беспокоюсь очень сильно и все мне кажется, что с Вами что-то стряслось. Если Вы помните, я в конце лета написала Вам длинное письмо, но от Вас ответа не было.

Я здесь случайно познакомилась с человеком, который Вас знает, он был здесь проездом - фамилии его я не помню, он из стокгольмского университета, швед, а теперь преподает в Лос Анжелосе. Мы говорили о Вас и это было мне очень приятно. ${ }^{334}$

Гуля, напишите мне сейчас-же, пожалуйста. Я надеюсь, что я ничем не обидела Вас? Последнее мое письмо было вызвано Вашим чудным письмом после Вашей последней поездки в Ленинград. Я много раз перечитала ее. Я писала Вам, что никто так много не видит в Сов. Союзе, как Вы. Только что оттуда вернулась моя приятельница, кот. всегда (каждые два года) видит А.А.А. Она мне сказала, что самые любимые поэты молодежи в Ленинграде - Мандельштам и Ходасевич. Стихи же ходят по рукам. Знаете ли Вы, что Шведская Академия выставляет кандидатуру А.А.А. на Нобелевскую премию? 335 Что Вы сделали с лентой магнетофона на кот. записали А.? Нельзя ли купить копию? Наш университет мог бы снестись с Вашим.

Гуля, не оставляйте меня без новостей. Жму Вашу руку.

Нина

334 Henrik Birnbaum (1925-2002), Swedish-American Slavist, professor at UCLA.

335 After visiting Achmatova, Rittenberg's companion Mesterton (see note 331 to Berberova's letter of 16 August 1962) asked Achmatova's colleague and neighbour Boris Vachtin how she would react to receiving a Nobel Prize in literature. This question gave birth to a false Leningrad rumor about her actual Nobel chances that apparently reached Berberova. In fact Achmatova was nominated for the first time in 1965. See my article "Anna Akhmatova and the Nobel Prize" in Unacknowledged Legislators. Studies in Russian Literary History and Poetics in Honor of Michael Wachtel (Stanford Slavic Studies 50, ed. L. Fleishman, D.M. Bethea, I. Vinitsky), Berlin 2020, 437-442. 
1 ноября 1962

Дорогой Гуля, я получила оба Ваши письма, спасибо. Оба адреса правильны - один университетский, где у меня кабинет, другой - домашний. Очень все интересно, что Вы пишете. Нельзя ли было бы «купить« копию ленты ААА? Если это возможно сделать, это сделает наш университет в официальном порядке. Такие вещи делаются, например, в Индианском университете: там купили мою ленту - я читала стихи старые и новые. Может быть будет пластинка.

Писала ли Вам, что здесь сейчас находится проф. Эрлих из Сиаттла, он внук Дубнова и сын Софии Дубновой (третьеразрядной поэтессы времен до первой войны, без претензий старушка). 336 Эрлих милейший человек, я давно таких не видела. Читает курс поэзии, но меня просил не приходить, не любопытствовать, так что я не хожу. Зовут меня в глухую провинцию, на большое и почетное место, в Охайо, но я не поеду. На это много причин. Библиотека здесь замечательная, Нью-Йорк под боком, и кроме того, я люблю свою квартиру, город и университет: здесь находятся у меня два близких мне друга, для кот. мой отъезд был бы очень тяжел (одному 27 лет, а другому 68). Да и я не хочу расставаться с ними - это мне близкие люди.

Жизнь у меня проходит интересно, но писать сейчас нет времени. Между тем, НАДО, потому что я затеяла большую вещь, за два года написала 220 стр. (машинных) и замерла. В голове же все стоит как «полная чаша«. Думаю, выкроить время на Рождестве.

Нобелевская премия, как и многое другое в нашей жизни, безумно опаздывает. Стейнбек должен был получить ее ровно 25 лет тому назад. ${ }^{337}$ Фросту ${ }^{338} 88$ лет - говорят он кандидатом был - почему ему ее не дали 30 лет тому назад??

Напрасно Вы пишете так об Адамовиче: 1) в 68 лет самое время выживать из ума. И он несомненно выжил. 2) Он сам мне говорил в свое время, что не прочь получить «подарок«, и «берёт«, - например «взял« - и это всем известно - в свое время от Владимира Дукельско-

336 Victor Erlich (Viktor Érlich, 1914-2007), author of the important monograph Russian Formalism (1955), was the son of the poet Sofija Dubnova (1885-1986) and a nephew of the great Jewish historian Semen (Simon) Dubnov (1860-1941).

337 John Steinbeck, the American winner of the 1962 Nobel prize in literature.

338 Robert Frost (1874-1963), one of the great American modernist poets. 
го (конец 20ых годов). ${ }^{339}$ Что до Ганского, то я его знаю. ${ }^{340}$ Он женат на сестре Юрия Мандельштама, ${ }^{341}$ ему лет за шестьдесят. Он пишет давно. Скромен и тих, не беден. Адамовича я не читаю. Ни Нов. Р. Слова, ни иных газет не читаю. Неинтересно, да и уровень уж очень упал. Могу себе позволить читать только то, что интересно. Времени не остается для дряни.

Нина

Durrell переведен на шведский - почти уверена. ${ }^{342}$ На франц. - конечно! Он имеет колоссальн. успех во Франции. Я сейчас читаю его во 2-ой раз.

339 Vladimir Dukel'skij (1903-1959), émigré poet and composer of popular music (under the pseudonym Vernon Duke).

340 Leonid Ganskij (pseud. of Leonid Gatinskij, 1905-1970), émigré poet and prose writer.

341 Tat'jana Štil'man (1908-1984), émigré poet, sister of the poet Jurij Mandel'štam (1908-1943).

342 The first Swedish translation of Durrell appeared in 1958. 
Милый Гуля, получила вчера Ваше заказное письмо. Почему полтора года тому назад Вы не прислали мне рукопись Лагорио? ${ }^{343}$ Я бы прочла ее, вероятно, приняла, дала бы прочесть двум другим моим со-редакторам в Нью-Йорке и она была бы напечатана теперь. Вы послали ее прямо в Мюнхен - я ничем не могу помочь Вам. Тем более, кстати, что я с сентября-октября не состою уже членом «редколлегии« Мостов: 1) потому что времени для этого нет и 2) потому что они стали дышать на ладан и видимо жить будут недолго. Что касается Ваших слов Хомякову ${ }^{344}$ о «традициях русской литературы, то я Вам скажу, что семь лет тому назад я однажды пробовала апеллировать к оным традициям, но мне ответили на это (люди, на десять лет старше меня!): «Может быть в ВАШЕ время так было, Ч.Ч., но в НАШЕ время все по-другому«.

Я читаю по книге в день: у меня летом два курса, в Индианском университете, а в сентябре я перехожу в Принстон, на положение профессора - не только славянск. факультета, но и «сравнительной литературы«. Все это весьма приятно, но ответственно, и на Рождестве было даже волнительно, когда два «лучших« здешних университета «спорили« обо мне. Сейчас все улеглось. В конце августа переезжаю в Принстон, кот. чуть ближе к Нью-Йорку (на юго-западе, а мы сейчас на северо-востоке). Курсы, Гуля, будут такие: летом в Индиане (для аспирантов): 1. История русской критики от Белинского до 1960 (по-русски) и 2. Русский роман от Анны Карениной до Живаго (по-английски). В Принстоне первый курс будет тот-же, а второй - Русский символизм. Еще не решено на каком языке. Сколько я перечитала за последние два месяца, и сказать Вам не могу! Переоценила Л. Андреева (плох) и Горького (иногда потрясающий), а Бунина «Деревня« - чудовищной силы, не могла успокоиться три дня. Трудно все это, особенно если думать о том, что биография писателя нынешних студентов не интересует, ей посвящается пять минут, содержание (кто кого убил/ любил/погубил) - еще меньше. И все состоит в том, что раскрываешь «приемы« и «образы«.

343 Natal'ja Lagorio (Potapenko, 1892-1974), émigré writer who had lived and worked in Stockholm in the early 1920s.

344 Rittenberg had sent an essay about Russian serfdom by Natal'ja Lagorio to Mosty which was primarily met with a positive response. A little later Lagorio received a refusal. In a letter of February 19 Rittenberg asked Gennadij Chomjakov (1906-1984, editor-in-chief of Mosty) about this inconsistency. 
Ваше письмо о Париже было страшно интересно. Терапиано всегда был надутый... Но что же они все-таки там делают?? Ведь в дне - 24 часа. Он и Одоевцева в божьем доме. ${ }^{345}$ Ну, хорошо. А чем же они все-таки заняты? ЕЁ воспоминаний (?) читать не могла: 40 лет она помнила свои диалоги с Гумилевым?? Не верю!... ${ }^{346}$ Жму Вашу руку.

Нина

345 Terapiano and Odoevceva were living in the home for old Russians in Gagny, sponsored by a charity organization.

346 Irina Odoevceva, Na beregach Nevy, Paris 1967. 
Нью-Хейвен, 6 июня 1963

Милый Гуля, я давно не писала Вам. Каюсь. От Вас же давно ничего не было, и я думаю, Вы страшно на меня сердиты. Я была ужасно занята всю весну: в сентябре я перехожу в Принстонский университет (профессором), буду там читать четыре аспирантских курса, - их надо было подготовить, тем более, что через неделю я еду на два месяца в Индиану, где два из этих четырех курсов буду уже читать. Словом, кроме обычной работы навалилось три пуда добавочной. Ничего «для себя« не писала уже год... Меня рвут на части потому что знают, что мне осталось 5-6 лет, не больше, работать регулярно, а затем придется выйти в отставку.

Может быть это письмо придет, а Вы в это время будете в Ленинграде. Я всегда с таким интересом читаю Ваши письма после поездки туда. Увидите ли Ахматову? Услышите ли что-нибудь? Я внимательно прочла статьи и речи - которые начались в декабре и еще, видимо, не кончились. Дело опять пошло под гору, с завинчиванием по всей линии. Пятая книга Эренбурга (Новый мир, март) показалась мне урезанной, даже типографски видно, что здесь и там что-то было вынуто, да и книга журнала задержалась выходом.

Прочитала я «40 отступлений« Вознесенского ${ }^{347}$ - насколько он замечательнее Евтушенко! Но и кроме Возн. есть сейчас замечательные (молодые) поэты. Их можно найти в «Дне Поэзии«. Знаете ли Вы журнал «Москва«? Там, в январском номере был реабилитирован Ходасевич и даже моя биографическая заметка (анонимно) была перепечатана. ${ }^{348}$ Считаю, что Каверин и Некрасов ${ }^{349}$ очень интересны, а Казаков ${ }^{350}$ и Аксенов ${ }^{351}$ - обещают быть большими писателями, если их не задушат. Вас. Гроссман тоже - обратите внимание на рассказ «Лось « ${ }^{352}$ - насквозь символичен, так же, как и Аксенов. Прочитайте книгу Пруцкова «Опыт литер.-худож. анализа«, это удивительная вещь: разобран «Обломов« так, как если бы Пруцков прочел новых

347 Andrej Voznesenskij, 40 liričeskich otstuplenij iz poèmy Treugol'naja gruša, Moscow 1962.

348 Vladislav Chodasevič, "Evropejskaja noč,," with a short unsigned introduction by Berberova, Moskva 1 (1963).

349 Viktor Nekrasov (1911-1987).

350 Jurij Kazakov (1927-1982).

351 Vasilij Aksenov (1932-2009).

352 Vasilij Grossman, "Los'," Moskva 1 (1963). 
западных критиков (а может быть мою статью в Новом Журнале? ${ }^{353}$ ). Я ее, зту книгу, даю студентам. ${ }^{354}$

Если напишете сюда, мне перешлют, а не то так прямо в Индиану: Slavic Workshop. Ballantine 502. Indiana University. Bloomington, Ind. Шлю Вам сердечный привет, Гуля, не сердитесь на меня.

Нина Leningrad 1962. 
Милый Гуля,

уже не помню, кто кому писал в последний раз. Давно это было. Как прошло Ваше лето? Были ли в Лен.? Кого видели? Начали ли преподавание в этом году, или у Вас другие планы? Как себя чувствуете?

Я переехала в Принстон и начинаю занятия послезавтра. У меня три курса в первом семестре и три курса во втором. Один - сквозь оба семестра - со студентами последнего курса: чтение русской прозы XIX в., в общем, курс скорее языка, чем литературы. Остальные четыре курса с аспирантами: история русской критики, русский символизм (поэзия), русский роман от Анны Карениной до Доктора Живаго и поэтика и техника поэтического перевода. Эти два последних курса - по-английски.

Принстон по сравнению с Нью-Хейвеном - дача. Перед окном трава-мурава, лужок, березы, кусты. Тишина полная. Живут только университетские в этом углу «города« (который состоит из двух улиц). Остальное - сады и парки с дивными виллами и, конечно, университетский городок в центре. Погода стоит летняя и у меня такое впечатление, что я переехала куда-то на юг, - отчасти так оно и есть. Немножко щемит сердце по оставленным в Йеле друзьям, но при наличии автомобиля, думаю, легко будет их навещать. Настроение пока смутное, потому что еще не привыкла ни к месту, ни к людям, и многого еще не разобрала. Посмотрим, какие будут студенты и аспиранты. И как скоро библиотека выполнит мой заказ с книгами - теперь здесь в Америке все библиотеки пополняются фото-экземплярами «ксерокс«, Вы наверное знаете этот способ копирования книг. Так что все, что нужно, достается во́-время для курсов. Недавно пришел «Символизм« Белого ${ }^{355}$ и ранние книги Вяч. Иванова. ${ }^{356}$ Кстати, что Вы думаете о его новой книге, выпущенной в Кларендон пресс? ${ }^{357}$ Напишите, не

355 Andrej Belyj's Simvolizm (1910) was reprinted in Munich in 1969.

356 Vjačeslav Ivanov, Prizračnost', Munich 1967.

357 Ivanov, Svet večernij, Oxford 1962. 
забудьте. Мне показались примечания О.А. Шор немножко смешными и старомодными, и очень дамскими. ${ }^{358}$

Читали ли Вы Лоренса Даррелла роман (четырехтомный) «Александрийский квартет«? Если нет, прочтите. У меня со времени Пруста не было такого шока - замечательный писатель (англичанин, живущий в Греции). Сейчас читаю его второй раз - не помню, чтобы когда-нибудь делала это с современниками.

Привет, милый Гуля.

Brown University (USA) переиздал Слонимского (А.) ${ }^{359}$ и Гиппиуса $(\mathrm{Bac} .)^{360}$ о Гоголе. Mouton (Гаага) переиздал Жирмунского ${ }^{361}$ и Эйхенбаума. ${ }^{362}$

358 Ol'ga Dešart (née Šor, 1894-1978), Vjačeslav Ivanov's third wife, his secretary and eventually archivist and text commentator.

359 Aleksandr Slonimskij (1881-1964), Technika komičeskogo u Gogolja (1923), reprinted Providence, R.I., 1963.

360 Vasilij Gippius (1890-1942), Gogol'(1924), reprinted Providence, R.I, 1963.

361 Viktor Žirmunskij (1891-1971), Voprosy teorii literatury. Stat'i 1916-1926, s'Gravenhage 1962.

362 Boris Ėjchenbaum (1886-1959), Skvoz'literaturu. Sbornik statej, s'Gravenhage 1962. 
Милый Гуля, я получила оба Ваши письма, и вообе я получаю все Ваши письма - ни одно за столько лет не пропало. Напрасно Вы беспокоитесь. О том, что Терапиано глуп, я уже знаю 36 лет - срок не малый! Он вообще (кроме того) - типичная старая дева. Я давно ничего не читала из того, что он пишет. Последнее, что мне попало в руки - его книга воспоминаний, где он не только глуп, но и недобросовестен: пишет свысока о Ходасевиче, которому он ВСЕМ обязан. Если бы не Ход., его бы никогда не напечатали Современные записки, и о книгах его не было бы сочувственных отзывов. Адамовича я тоже давно не читала - русской печати, кроме Нового Журнала, не вижу. Недавно просмотрела несколько номеров Возрождения - это так провинциально, что мне даже стыдно стало. Живем в роскоши умственной западной жизни, а пишем - словно не по-русски, а по-болгарски.

В Европу я не собираюсь, гланым образом потому, что хочу писать этим летом и поселиться на два месяца где-нибудь в тихом и непременно прохладном месте, где бы можно было «подвинуть« ту длинную вещь - автобиографического характера - которую я начала три года тому назад и к которому не было времени прикоснуться за последние полтора года. Написано около 225 страниц, но и те надо подчистить основательно. В Европу я хочу приехать на целый год, когда мне будет возможным вернуться вырваться отсюда на такой длинный срок. Пока не вижу, когда и как можно будет это сделать. Работы много - со студентами и с аспирантами, здесь, в Принстоне, гораздо больше у меня ответственности, и студенты интереснее.

Чижевского прочла, но не могу, как ни стараюсь, найти в себе интерес к футуризму, Хлебникову и прочим. ${ }^{363}$ Не знаю почему это во мне: живопись люблю новую и абстрактную, а музыку не очень, а поэзию - вовсе нет. То, что печатается в СССР, мало меня утешает. Там по-моему только один настоящий писатель сейчас - В. Каверин; а Аксенов и Казаков очень талантливы, но они сейчас видимо прижаты и ничего не печатают. Я читала их рассказы (и Окуджавы) - это было очень хорошо. Читали ли Вы их?

Привет Вам сердечный.

Нина

363 Dmitrij Tschižewskij (1894-1977), Anfänge des Russischen Futurismus, Wiesbaden 1963. 


\section{PRINCETON UNIVERSITY}

\section{PRINCETON, NEW JERSEY}

Slavic Languages and Literatures

28 января 1964

Дорогой Гуля, оба Ваши письма получила. О Бродском ничего не знала, и стихов его не читала. ${ }^{364}$ Я вижу многих (студентов и профессоров) уезжающих «туда« и приезжающих «оттуда«. Всё всегда грустно, даже когда как-будто делается легче в материальном отношении. Немножко грустно, или очень сильно грустно.

У меня были очень долгие рождественские каникулы: здесь устроено так, что работают студенты три месяца, а в середине декабря их отпускают на две недели, а потом, до конца января, идет так называемый «ридинг период« - они читают. Затем экзамены. Это, конечно, старшекурсники. У меня большая группа (трех и четырехкурсники), мы читаем в классе Записки из подполья, Шинель и прочее, а дома рассказы Каверина, Некрасова (Виктора) и др. Работают прекрасно. 5-го февраля начинается второй семестр.

Но самое для меня интересное, это аспиранты. Было два курса (лекционных) и будет два. Из этих, которые будут, один лекционный - Русский роман от Анны Карениной до Доктора Живаго, наполовину я веду его на английском языке и все их чтение - по-английски (уйма!). Второй курс который я страшно сама люблю - семинар по поэтике и технике поэтического перевода. Тут уж прямо таские тонкости идут, что даже профессора ко мне ходят (три). Вы просите прислать лекции - Гуля, но это совершенно невозможно: во-первых лекций нет, а есть только конспекты, неужели Вы думаете, что я по писанному читаю? Во-вторых - ... впрочем, в этом случае во-вторых совершенно уже и неважно.

Очень рада успехам Греты Герелль. Она - чудный художник. Сама я ничего не пишу, но летом уеду на два месяца и буду вести монастырскую жизнь - на севере, у границы Канады. Засяду там и «двину« дальше длинную «штуку«, -225 страниц уже есть.

Привет самый сердечный.

Нина

364 Iosif Brodskij was arrested on 13 January and sentenced two months later to five years exile in northern Russia for "parasitism." His poetry began around this time to find its way to the West, but it was not until 1965 that it was published as a collection (Stichotvorenija i poèmy, New York). Rittenberg was following him at an early stage and had evidently "run into him" somehow in Leningrad. 
(Undated, summer 1964)

Спасибо за письмо, милый Гуля. Я живу в «Артистическ. колонии« и пишу целыми днями - света не вижу! Послезавтра еду на 2 нед. к морю, а 20 авг. возвращаюсь домой в Принстон. Отдохнула, пришла в себя. Мозги опять заработали. Привет.

Нина 
Дорогой Гуля, спасибо за письмо, как всегда интересное. Вчера, наконец, я познакомилась с Ржевскими. Он был мил, но я не могу простить ему его (тошнотворного) рассказа о «снохаче« в Нов. Журнале (после которого меня не в переносном смысле стошнило). Она мне очень понравилась, и внешне у нее много прелести, и она так элегантна, и умна, и мила, что просто чудо! Словом, я рад, что они здесь устроены хорошо и видимо - довольны. Новый Журнал не выйдет в декабре - у Гуля был сердечный припадок, как Вы вероятно слышали (был припадок и у Адамовича). Гуль деспот и никого не приготовил, чтобы «в случае чего« заменить его в журнале - его со-редакторам одному 80 лет (Денике) и он в Париже живет, а другой (Тимашев) одной ногой в гробу. ${ }^{365}$ Что будет - неизвестно. Впрочем, последние номера были так плохи, что иногда мне приходит мысль: стоит ли журнал продолжать? Однако, все говорят кругом, что стоит, и что в России его читают.

Что будет в России - неизвестно, после ухода Хрущева, который (уход) произвел во всем мире угнетающее впечатление. ${ }^{\mathrm{X}}$

Я буду летом в Европе. Мечтаю увидеть Вас. Напишите, какие у Вас планы. Я надеюсь быть в Париже в июне, а потом на возвратном пути несколько дней в сентябре. Будет ужасно приятно опять увидеться. С Ржевскими тепло говорили о Вас и мне опять вспомнились наши дружеские разговоры о поэзии и Ваше чтение стихов Ратгауза, на которое я так рассердилась на пляс де Вож. ${ }^{366}$

Ахматова видимо будет в Сицилии в декабре - премии будут раздавать в декабре. Что за глупости пишет Кленовский ${ }^{367}$ о том, что об-во «отказалось выдать Ахматовой премию«? 368

365 Jurij (Georgij) Denike (1887-1964), sociologist and journalist. He died soon, two years short of 80 . Thus his co-editor Nikolaj Timašev (1886-1970), also sociologist and journalist, was somewhat older.

366 Berberova could not accept Rittenberg's high opinion of the poet Daniil Ratgauz (1868-1937).

367 Dmitrij Klenovskij (1893-1976), poet of the second émigré wave, Rittenberg's correspondent of many years.

368 Achmatova had been awarded the so called Etna-Taormina prize. Sensationally enough, she was allowed to accept it in Catania, Sicily in 1964. There was of course a lot of speculation before that, not least in Klenovskij's letter to Rittenberg of 26 October 1964 (in Rittenberg's archive), in which he wrote that Achmatova had reportedly refused the prize due to what she had heard about internal disagreements within the awarding organization. (In the summer Achmatova had sent him a greeting via Rittenberg.) 
Молодых поэтов СССР, особенно ленинградцев, читаю, и нахожу некоторые стихи очень замечательными, особенно женские. Но имена появляются и исчезают. Вознесенский и Евтушенко очень мало интересны и даже часто плоховаты.

Я продолжаю обдумывать дальнейшие главы своей автобиографии, написано 500 стр. Буду писать на рождественск. каникулах и месяц где-нибудь в тихом углу Европы - м. б. и кончу в 1965 году.

Милый Гуля, не забывайте! Скоро м. б. увидимся.

Нина

${ }^{\mathrm{x}}$ Способ «выгонянья« людей в тоталитарном государстве не меняется. Впрочем, 25 л. тому назад его бы убили. 
Дорогой Гуля, спасибо за - как всегда - интересное письмо. Очень, очень была бы рада свидеться с Вами в Париже. Я сама собиралась Вам писать о своем «расписании«, и просить, чтобы оно совпало с Вашим. Я буду в Париже 14 июня (приеду на Квин Мери) и останусь там до 8 июля. Затем поеду в Сицилию - на месяц, писать. Затем пошатаюсь по Италии, где в некоторых непредвиденных местах меня будут ожидать различные друзья. В самом конце августа вернусь в Париж (или в начале сентября) и 10 сент. выеду в Америку. Остановлюсь я в Париже у моей подруги (еще юности), персианки, которая живет около пляс Вово и улицей Боэси (21 rue Miromesnil). Видели ли Вы фотографии Ахматовой в Литературной газете? ${ }^{369}$ Читали ли Вы интервью в «Ди Вельт $\ll ?{ }^{370}$ Как все это грустно! Лучше бы этого не было. Она видимо совершенно не понимает, что разрушать однажды созданный образ (который успел стать мифом) - это значит разрушать самый корень вещей. Ее двойной подбородок меня убил. Неужели и ее задело разрушение «эстетики« в Советском Союзе? Я читаю все, что выходит интересного в России, не присылайте мне ничего. Вознесенского знаю и ценю. Но особенно люблю н е к о т о р ы е стихи Бродского, хотя он и не тот гений, которого я жду, чтобы перевернуть вверх ногами всю нашу устарелую просодию, или вывернуть ее наизнанку.

О Кленовском согласна на 100 процентов. ${ }^{371}$

Гуля, что с Гретой? В декабре я писала ей, что приезжаю в Европу, что надеюсь ее видеть. На это - ни гу-гу. Она не выказала никакой радости по этому поводу. Здорова ли она? Увижу ли я ее, дорогую мою Грету, этим летом, или она увязла в антропософии окончательно и в ненависти к нашему веку? Об ужасах современной цивилизации она год назад писала мне письмо, я «вступила с ней в спор«. Она, кажется, была недовольна мной. Все это между нами. Но я была бы очень бладодарна Вам, если бы Вы узнали у нее, собирается ли она в Париж летом? Скажите ей мои планы о Париже. Скажите, что я беспокоюсь.

Ваша

Нина

369 Achmatova's review of Ėmma Gerštejn's (1903-2002) "Vokrug gibeli Puškina (Po novym materialam)," Novyj mir 2 (1965), published under the rubric "Zametki na poljach" in Literaturnaja Gazeta, 16 March 1965.

370 Berberova is evidently alluding to Willi Bongard's interview with Achmatova in Die Zeit, 5 February 1965.

371 Rittenberg apparently relayed Klenovskij's critical opinions of his fellow writers and others, which reinforced Berberova's distrust of him. 


\section{PRINCETON UNIVERSITY}

\section{PRINCETON, NEW JERSEY}

Дорогой Гуля, пишу Вам несколько слов - страшно занята эти дни: год близится к концу и ужасно много дел. Расскажу обо всем, когда увидимся. Ваше письмо и открытку получила. Не собираюсь ни в коем случае с Вами спорить: хочу разговаривать и только. Мирно и мило. И так, чтобы только «высказать« свое мнение и прослушать Ваше, но не убеждать Вас ни в чем, и меня тоже Вы не убедите. Фотографы, как напр. Картье Брессон, гораздо «драматичнее« для меня, чем реалистическая живопись. ${ }^{372}$ А что касается абстракционистов, то многих из них я люблю.

Я приеду в Париж около 15-го июня, так что если Вы мне позвоните по телефону, то мы сможем увидеться и провести время вместе. Телефон мой Анжу 01-47.

Вы не ответили мне на вопрос о Грете: как я ее ни люблю, но ее поведение начинает меня о б и ж а т ь: вообразите себе, что я написала ей в декабре, что приезжаю в Париж летом, что хотела бы знать, будет ли она в Париже в это время, и не только не получила от нее «радостного« ответа, но даже и вообще ответа не получила. Что с ней??

Пока все. Обнимаю Вас и больше писать не буду. Скоро увидимся. Про Ленинград жду рассказов с нетерпением.

Нина

372 Henri Cartier-Bresson (1908-2004), one of the great (French) photographers of the time. 
Принстон, 17 сент. 1965

Дорогой Гуля, не называйте меня Н.Н. - что за безобразие! А то я буду называть Вас «ваше превосходительство«, или как однажды при мне Шагал ${ }^{373}$ назвал вел. Кн. Бориса Владимировича ${ }^{374}$ - «ваше императорское сиятельство«. Ваше письмо, перед отъездом в Ленинград от 10 июля, получила, когда вернулась в Париж - 6-го сентября. Третьего дня вернулась в Принстон, очень рада была приехать в тихое, $_{\text {просторное }}^{\mathrm{X}}$ место, где меня ждали мои книжки и бумажки. Пишу Вам сегодня кратко, потому что мне надо написать около 10 писем срочных и послать столько же чеков - по пришедшим в мое отсутствие цветам. Здесь все чудно и я начинаю лекции 27-го. Книгу свою я - вчерне кончила (600 стр. печатных) и буду последнюю главу, написанную в Таормине, полировать во время рождественских каникул. Из Таормины я поехала так: Рим - Перуджия - Ассизи - Флоренция - Болонья Равенна - Верона - Венеция, где мы с Вами в след. раз встретимся, будем жить в отеле Савона, около лагуны, за отелем Даниели - там я жила. Из Венеции проехала я в Мюнхен на три дня, а потом в Париж на 4 дня, а затем села на «Франс«. Все было замечательно: природа, музеи, люди, старые и новые, моя работа, книги, кот. я читала, и города, кот. видела. И одним из самых приятных была встреча с Вами - я часто вспоминаю о ней.

Гуля, напишите мне скорее, как все было, в каком состоянии AАA? ${ }^{375}$ Как чувствуют себя Германы, что чуется в воздухе - Вы всегда так чудно пишете после поездки в Ленинград. Видели ли Вы ААА? Может быть Вы сердиты, что от меня письма не было долго? Но, Гуля, я не могла написать Вам раньше.

В очень передовом журнале (литературном) была критика на Верта отрицательная, злая и, пожалуй, несправедливая. Журнал называется «The New York Review of Books «. ${ }^{376}$

Пока все. Пишите, с нетерпением жду Вашего письма. Обнимаю Вас.

Нина

Видела Адамовича в июле. Он гага.

${ }^{\text {и чистое }}$

373 Marc Chagall.

374 Grand Duke Boris Vladimirovič (1877-1943).

375 Anna Achmatova.

376 See note 131 to Berberova's letter of 18 March 1949 (and also Berberova's letter of 30 April 1954). Walter Laqueur's critical review of Werth's Russia at War 1941-1945 was published in The New York Review of Books, 15 July 1965. 
Драгоценный Гуля, я получила оба Ваши письма, но впредь УМОЛЯЮ Вас не думать о том, что письма пропадают. Все письма всегда доходят, но я не могу отвечать сразу, потому что ужасно занята. Грете я писала в начале октября, когда беспокоилась о Вас, не получая писем. Она, как все женщины, не смотрит на даты писем и напрасно беспокоит Вас. После этого я получила Ваше такое (как всегда) интересное письмо о поездке в Питер, об ААА и о встрече с Саррот.

Этот год у меня особенно интересный: во-первых - шесть диссертаций, от Державина до Серапионов. Два дня - лекции, два дня - беседы с диссертантами. Три дня от семи до семи я работаю дома. Вот моя жизнь. Кроме того, по моей инициативе здесь создался «клуб«, который мы называем Академией (в шутку). В ней по-русски обсуждаются русские дела профессорами различных факультетов, говорящими по-русски иногда очень хорошо. Есть и два бывших дипломата (американских, живших в Москве в свое время). Собрания происходят два раза в месяц у меня, и я вроде ментора - отправляю их русскую речь и играю роль генсека и хозяйки.

Очень взволнована арестом Синявского, кот. написал замечательную статью о Пастернаке (Больш. библ. поэта). ${ }^{377}$ Даниэль - тоже сотрудник Нового мира и тоже сидит. ${ }^{378}$ Что думает Твардовский об этом нам здесь неизвестно, он сейчас гуляет по Европам. ${ }^{379}$

Саррот я знаю с 1945 года, когда она даже раз была у меня с мужем. Она начала писать в 50 лет. Она тогда говорила мне, что у нее три дочки, кот. она вырастила, и когда они выйдут замуж, она собирается заняться литературой. Она - дочь Черняка, брата революционера, не то казненного царем, не то выгнанного из России после каких-то рев. действий. Ее отец прижил ее от домашней прислуги (что делает ей честь, конечно) и привез ее совсем маленькой в Париж, когда эмигри-

377 Boris Pasternak, Stichotvorenija i poèmy, Moscow-Leningrad 1965 (with a foreword by Andrej Sinjavskij).

378 Andrej Sinjavskij and Julij Danièl' were arrested on 8 and 12 September 1965, respectively, accused of smuggling satires written under pseudonyms to the West. Their arrest led to the birth of a Soviet civil rights movement, which first made itself manifest on Soviet Constitution Day on 5 December. Its most important slogan "Respect Your Own Constitution!" - became a guiding principle for the entire civil rights movement. Sinjavskij and Danièl' were sentenced on 14 February 1966 to labor camps for seven and five years, respectively.

379 Editor-in-chief of Novyj mir Aleksandr Tvardovskij. 
ровал от проклятого царизма в 1905 г. Я его знала тоже. ${ }^{380}$ Романы ее я пробовала читать, но не смогла - так они скучны. Бовуар и Сартр видимо тоже разочаровались в ней (см. третий том воспоминаний Бовуар ${ }^{381}$ ) - она пишет о предметах, - кому это нужно? Я и в жизни не люблю предметов, а в литературе они по-моему просто смертельно не нужны. Неужели ее переводят и читают в СССР?

Романы Даррелла идут в след. порядке: Джустина, Бальтазаре, Монтолив и Клея. Я уверена, что они Вам понравятся. У нас с Вами за последнее время замечается полное совпадение мнений. Или это от взаимной любви???

Обнимаю Вас. Напишите мне о СВОИХ делах и жизни. Что Вы ДЕЛАЕТЕ?

Нина

380 Rittenberg evidently met Nathalie Sarraute (1900-1999) in Leningrad. She occasionally visited her original homeland. In August 1963 she called on Anna Achmatova in Komarovo. She was born Natal'ja Černjak. Her father Il'ja (?-1949) was a chemist. His brother Jakov, a revolutionary wanted for an alleged post office robbery, was arrested in 1906 by the Stockholm police. The tsarist authorities demanded his extradition, but (the future Social Democratic Prime Minister) Hjalmar Branting and others swayed opinion in his favor, and Sweden deported him to Belgium. Before his ship reached Antwerpen, he died of poisoning in February 1907. The Ochranka was strongly suspected but there was never any definitive proof.

381 Simone de Beauvoir, La Force des Choses, Paris 1963, p. 650. 
Дорогой Гуля, спасибо за письмо. Хочу Вам написать о маленьком открытии, которое я сделала недавно:

Помните, я просила Вас пойти в Ленинграде к Иде Наппельбаум? Оказывается, ее отец был знаменитым в СССР фотографом. О нем пишут статьи в сов. журналах и печатают репродукции его работ. Посмотрите «Москву« за 1964 год, кн. 6, стр. 177. ${ }^{882}$ Имеется упоминание о третьей дочери, Ольге, но не о двух первых, кот. я знала. ${ }^{383}$ Студия видимо все еще существует на Невском (72?). Туда пойдет в феврале мой друг, автор книги о Мандельштаме, проф. Принстона Кларенс Браун, кот. едет в СССР на пять месяцев. Он постарается найти там старые фотографии (20-х г.г.) Гумилева и некоторых др. ${ }^{384}$

За это время я затонула в сов. журналах. Есть много интересного в критике и я собираюсь совершенно переделать мой курс «История критики«. Пусть студенты сами читают, если хотят, Добролюбова и Писарева, но я их выкину вон и предамся анализу современных «оттепельных« авторов. Очень, по-моему, они важны для всей картины сегодняшнего дня.

Еще о Наппельбауме: в 1964 г. была выставка его работ в Центр. Доме Литераторов (в Москве). Кроме того - он был автором книги «От ремесла к искусству« (о фотографии).

Почему Кленовский жалуется, что я ему не пишу? Мы перестали писать друг другу лет пять тому назад. Последнее, что я получила от него, была какая то душеспасительная рождественская карточка. Карточек я не посылаю, и ничего душеспасительного не люблю. Но Кленовскому желаю всяких благ. Переписываться без надежды (и желания) увидеться я считаю потерей времени.

Адамович произвел на меня грустное впечатление. Он принадлежит к тем людям, кот. любят больных собак, лечат их, а когда собаки выздоравливают и задравши хвост, от них убегают, то эти люди бросают в собаку камнем. Как он ненавидит литературу! Т.е. все «успешное«, новое в ней, как в СССР, так и на Западе он называет все новое «бойким « - для него даже Пушкин «слишком боек«.... Но Вы продолжайте его любить: мы на этой почве с Вами не поссоримся! И вообще мы

382 “Portrety pisatelej. Fotografii M. Nappel'bauma," Moskva 6 (1964).

383 Ol'ga Grudcova (1905-1982), literary critic.

384 Clarence Brown (1929-2015), Slavist and translator. 
видимо уже никогда не поссоримся, а будем продолжать любить друг друга. Как Ваше здоровье, Гуля, и как идет Ваша жизнь? Почему Вы никогда больше не пишете мне о себе? Это мне столь же интересно, как и остальное. Вы больше не преподаете? Что Вы делаете?

Обязательно напишите о Вашей жизни. Не забудьте.

Нина 


\section{PRINCETON UNIVERSITY}

\section{PRINCETON, NEW JERSEY}

Slavic Languages and Literatures

423 Pyne Administration Bldg.

6 марта 1966

Дорогой Гуля, я на этот раз сердита: с осени я спрашиваю Вас в каждом письме о Вашей жизни, о работе, о здоровье, о настроении - и Вы ничего на это не отвечаете. Как это понять? Преподаете ли Вы? Здоровы ли Вы? Что делаете? Чему радуетесь? Почему ничего об этом мне не пишете? Если Вы храните мои письма, то можете проверить, что в каждом из них было спрошено и ни на один вопрос Вами не было отвечено. Вместо этого Вы мне пишете изложение статей и рассказов из сов. журналов, кот. я все получаю (в библиотеке), все читаю, и ради Бога не присылайте мне никаких копий - я по крайней мере 8 журналов в месяц просматриваю и все издания Академии Наук: Если Вы мне не напишете в следующем письме О СЕБЕ, то я прекращу дружбу с Вами. Какой Вы несносный человек!

Рукопись моей книги лежит у меня на столе. В ней 780 машинных страниц. Гуль хочет оттяпать первую часть у меня для июльской книжки Н. Ж. Может быть дам. Пока надо все перечитать, поправить опечатки машинистки, сделать «кое-кто« (Указатель), словом дней десять или больше просидеть над книгой. Отложу до весенних каникул - через три недели. Сейчас ужасно много читаю. Никаких книг по русской литературе издавать не собираюсь (курсы), но собираюсь написать большую статью летом о некоторых вопросах в советской критике после 1960 года.

Сегодня в газете - про смерть Ахматовой. ${ }^{385}$ Стало как-то тоскливо на душе. Какие у Вас планы? Читаете ли Вы Нов. Журнал? Там в мартовской книжке будет материал о Серапионовых братьях - очень интересный, прочтите обязательно. ${ }^{386}$ Каверина уже вышла книга об этой эпохе. ${ }^{387}$ Видели ли Вы Цветаеву в Больш. Библ. Поэта? Это событие. ${ }^{388}$

385 Achmatova died on 5 March.

386 Berberova's student Gary Kern (b. 1938) was responsible for the publication: "L. Lunc i ‘Serapionovy brat'ja,"” Novyj Žurnal 82 (1966).

387 Veniamin Kaverin, “Zdravstvuj, brat. Pisat'očen' trudno...” Portrety, pis'ma o literature, vospominanija, Moscow 1965.

388 Marina Cvetaeva, Izbrannye proizvedenija, Moscow-Leningrad 1965 (with a foreword by Vladimir Orlov). 
Что Вы знаете о Тарсисе и как объясняете это происшествие? ${ }^{389}$ Я абсолютно не имею никакой теории. Это кажется какой то скверный анекдот.

Гуля, хоть я и сержусь, но жду ответа очень, и нежно обнимаю Вас.

Нина

389 Valerij Tarsis (1906-1983), one of the first post-Stalin "dissident" writers, forced to emigrate in 1966. Gleb Struve (see note 483 to Berberova's letter of 22 November 1969) and Roman Gul' (see note 253 to Berberova's letter of 27 April 1957) had different opinions of his role. 
Дорогой Гуля, спасибо за письмо. Теперь по крайней мере я знаю, что́ Вы и ка́к Вы, а то писали Вы все об «умном«, а о своем здоровье, работе, планах - ничего! У меня заканчивается тут учебный год. Был он очень интересен и я думаю, такого года у меня давно не было. Книга моя лежит у издателя. А здесь я дружила с разными интересными людьми: Джордж Кеннан, ${ }^{390}$ д-р Оппенгеймер, ${ }^{391}$ Луи Фишер (автор «Ленина«); в гости к нам сюда приезжали Ися Берлин, ${ }^{392}$ Макс Хейворд ${ }^{393}$ и Ник. Набоков, ${ }^{394}$ не считая Р.О. Якобсона (из Харварда) и других «местных«...

Теперь вот что: Луи Фишер едет послезавтра в Европу и будет в Стокгольме. Он хочет познакомиться с Вами, если Вы будете в городе в начале июня. Он остановится в отеле Плаза (в Гран-отеле не было комнат) и останется от 5 до 10 утром (июня) в Стокгольме. Он просит Вас позвонить ему (лучше утром) в один из этих дней. Он - мой друг, живет почти рядом. Здесь, в США, он персона грата. Интересный, умный человек, жил в СССР 14 лет, был на Испанской войне, написал десяток книг. Пожалуйста, снеситесь с ним. Ему будет с Вами интересно (а Вам - с ним). ${ }^{395}$

Ник. Набоков привел ко мне однажды Баланчина и Баланчин бабочкой порхал у меня по квартире. ${ }^{396}$

Теперь скажу Вам, что раз и навсегда Вы мне не обещайте присылать сов. журналов, потому что сюда приходит ВСЕ буквально, что мне нужно. Я читаю очень много, особенно критического и историко-литературного, так что не беспокойтесь и не тратьте денег. Читали ли Вы книгу Ю.Н. Анненкова, кот. только что вышла в Вашингтоне ${ }^{397}$ В ней очень много интересного («легкое« чтение, конечно). Контроверза

390 George Kennan (1904-2005), American diplomat and historian who formulated the basis of "containment."

391 Robert Oppenheimer (1904-1967), American theoretical physic, professor at UCLA.

392 Isaiah Berlin (1909-1997), Russian-British political theorist and historian of ideas.

393 Max Hayward (1924-1979), British translator of Russian literature.

394 Nicolas (Nikolaj) Nabokov (1903-1978), composer, Vladimir Nabokov's first cousin.

395 Louis Fisher (1896-1970), Russian émigré journalist, known especially for The Life of Lenin (1964).

396 George Balanchine (pseud. of Georgij Balančivadze, 1904-1983), after Fokine the most significant twentieth-century choreographer.

397 Jurij Annenkov (1889-1974), portraitist, novelist, author of the book of memoirs Dnevnik moich vstreč. Cikl tragedij 1-2, New York 1966. 
Струве-Гуль (о Тарсисе) меня смущает. Тарсис мне НЕ нравится, и никому НЕ нравится.

Я теперь в переписке с несколькими сов. писателями, в том числе с Евтушенко. Он пишет очень милые письма, и совсем молодые. А Зильберштейн (достоевсковед) был 4 месяца в Париже и купался там как сыр в масле - эмиграция ни в чем души не чаяла! ${ }^{398}$ Он купил архивы Тэффи и С. Маковского. ${ }^{399}$

Гуля, пишите мне. Я до 28 июня здесь. Затем на месяц еду в артистич. колонию, где была в 1964 г., помните? Черкните мне о своих планах. Повидайте Луи. Обнимаю Вас.

Нина 
Дорогой Гуля, не сердитесь, что я долго не отвечала на Ваше письмо и не поблагодарила Вас за Ваше милое отношение к Луи Фишеру, кот. без Вас бы пропал. Он написал мне, что Вы были прямо ангелом - я другого и не ожидала, конечно. Где Вы летом? Что думаете делать зимой? Выходите ли в отставку? Едете ли в Ленинград?

Я опять живу (как 2 года назад) в «артистической колонии«, а по-нашему - доме отдыха, где все очень удобно и роскошно, где я целый день работаю, а после 4-х купаюсь, и вечером играю в шахматы с одним печальным и оригинальным человеком. Мне будет очень интересно, что Вы скажете, когда прочтете мою статью, кот. я только что закончила (огромную, 50 страниц) о новых веяниях в сов. критике. Там большие идут в этой области перемены. Рубят окно в Европу. ${ }^{400}$ Ждановские принципы летят, как щепки, в разные стороны.... ${ }^{401}$

Книга моя по-английски выйдет не так скоро, надо ее перевести, а для этого - найти хорошего переводчика. Пока он еще не найден. Хочу чтобы мой стиль сохранился, весь юмор и своеобразие, какое в книге есть. Но, конечно, сам факт подписания контракта с большим американским издательством уже сам по себе - великая радость. По-русски книга выйдет, конечно, но когда и где - я пока не знаю. Подождем - увидим. Гуль хотел бы в «Н.Ж.« ее - целиком или хотя бы в отрывках, но я думаю, что это ни к чему.

C Тарсисом, Гуля, надо быть осторожным: неизвестно, что он такое. М.б. совсем страшный человек. Впрочем он глуп, как пень. Я видела людей, кот. его видели. Он нигде не бывает один, только с солидаристами, и отвечают они за него. А он по бумажке читает свои «декларации«. На вопрос: почему его выпустили, он сказал, что он им здесь менее опасен, чем там. Как Вам это понравится?

Приехал после 4х месяцев жизни в Москве мой друг и коллега Кларенс Браун (спец. по Мандельштаму). Говорит, что видел в СССР представителей только «второй литературы«. Что это за люди - не совсем понимаю: они не печатаются, читают друг другу свои произведения,

400 Allusion to the opening of Puškin's Mednyj vsadnik: "Prirodoj zdes' nam suždeno/ V Evropu prorubit' okno..." (which in turn is based on Francesco Algarotti's remark about Petersburg as Russia's window to Europe).

401 Allusion to the old Russian saying (that Stalin also reportedly uttered): "Les rubjat, ščepki letjat." 
и всех презирают - м.б. гении, а м.б. и неудачники? Исследуйте этот вопрос, когда будете там.

Я получила месяц тому назад письмо от Евтушенко из Парижа. Он просил ему писать в Москву, писал, что читал меня с интересом и хочет переписываться. Я послала ему длинное письмо, но ответ не получила. Это - абсолютно между нами.

Обнимаю Вас. Пишите мне в Русск. Департ. в Принстоне. Буду дома 28-го.

Нина 
1 сентября (1966?)

Дорогой друг, шлю привет из дивной чудной божественной Венеции. Надеюсь, Вы благополучны? Через 2 нед. буду в New Haven. Надеюсь там найду от Вас письмо.

Привет.

НБерберова 
Дорогой Гуля, опять Вы ничего не пишете о себе, о своем здоровье. Что у Вас за привычка молчать о себе? Мне все интересно, и когда Вы сообщаете, что Вас оперировали, меня это беспокоит. Пожалуйста, расскажите побольше о своей жизни. Вышли ли Вы в отставку? Чем занимаетесь? Что вообще с Вами происходит? Были ли в Питере? Собираетесь ли в Питер? Теперь отвечу Вам на Ваше последнее письмо:

Книгу свою (автобиографию, где есть про Вас немножко очень ласковых слов) я закончила еще весной и ее немедленно взяли в большое амер. из-во, Харкур, Брэс и Уорлд. Сейчас ее переводят на английский под моим наблюдением. Переводчик - милый мой и драгоценный (молодой) друг, сейчас уже профессор колледжа в Массачузетсе, Радли, кот. пять лет тому назад получил докторат в Харварде написав диссертацию о Ходасевиче. ${ }^{402}$ Его мать, знаменитая Трижэр, - здесь все равно что Диор во Франции. ${ }^{403}$ Значит - это первое дело. Второе дело - огромная (50 стр.) статья «Советская критика сегодня«, кот. я готовила три месяца (апрель-июнь) и написала в июле. Она будет в Нов. Журн. в декабре и марте (сент. я не поспела) и тогда, в декабре, я вышлю Вам 7 стр. к ней библиографии - не могла заставить Гуля дать мне семь страниц для этого, журнал не научный и Гуль в общем прав. ${ }^{404}$ Вы увидите, что там делается, в недрах критики. Очень интересно. Третье: готова статья на двух языках сразу о последней книге Набокова «Бледный огонь«. ${ }^{405}$ Это будет пока моя публичная лекция здесь. Печатать конечно буду, но позже. Четвертое - и самое пожалуй любопытное, от чего Вы не сразу оправитесь: я продала права́ на моего «Чайковского« совето-американской фильмовой компании. Фильм будет на двух языках, крутиться будет в СССР, и меня туда зовут Мих. Ромм $^{406}$ и Нагибин ${ }^{407}$ - кот. пишет сценарий по моей книге. Это первый случай, когда эмигранта «употребляют« в дело в Москве. Каково?? Это такое событие здесь (было в газетах и т.д.), что не все еще пришли в себя, в том числе и я. Деньги небольшие, но почет велик. Дело имела с американцем, Д. Тёмкиным, кот. директор музык. части. ${ }^{408} \mathrm{OH}$

402 Philippe Radley (1935-2015).

403 Pauline Trigere (1912-2002), fashion designer from Paris, died in the United States.

404 "Sovetskaja kritika segodnja," Novyj Žurnal 85-86 (1966-1967).

405 "The Mechanics of Pale Fire," TriQuarterly 17 (1970).

406 Michail Romm (1901-1971).

407 Jurij Nagibin (1920-1994).

408 The Russian-born conductor and composer Dimitri Tiomkin (1894-1979) wrote the music to a number of well-known Hollywood films. 
уже в третий раз поехал в Москву и на днях привезет мне сценарий Нагибина, кот. я буду «улучшать« (?). ${ }^{409}$

Пока все. Видите, какое письмо - только о себе. Сделайте то же самое, Гуля. Обнимаю Вас. eventually replaced by Igor' Talankin (1927-2019). See note 532 to Berberova's letter of 13 March 1971. 
18 декабря 1966

Бесценный Гуля! Вчера - Ваше письмо, а я, собака, не ответила на предыдущее. Так была занята - не только курсами в уни-те, но и своими делами (литературными). Сначала хочу Вам пожелать приятных праздников и счастливого Нового года. Теперь скажу о себе:

Во-первых книга (Автобиография) переводится, - медленно, но верно. Переводчик - друг мой (ему 32 года), Харвардский - сначала аспирант, а теперь профессор. Написал пять лет тому назад диссертацию о Ходасевиче. Все ему знакомо и интересно, и он рвется в бой, но занят страшно, и я ему помогаю. ${ }^{410}$ Вообразите, что он сын здешней первой портнихи - как Диор во Франции!! И я познакомилась с мамашей, и попала в невероятный круг людей. Но это - небензахе. ${ }^{411}$

Второе: меня пригласили писать в здешнюю единственную литературную передовую, смелую, культурную, газету-журнал. Выходит два раза в месяц, выглядит, как Нувель Литерер (издали) но на 40 страницах. Началась она четыре года (кажется) тому назад и завоевала себе место. Все ее читают - хочу сказать, интеллектуалы. Это такой для меня сюрприз, что я еще не пришла в себя. Конечно гораздо интереснее, чем-то, что случилось с Голливудом и Чайковским. Для начала я написала им по-английски (!!!) - в первый раз в жизни сразу по-английски - статью о только что вышедшей книге проф. Карлинского о Цветаевой (жизнь и творчество). ${ }^{412}$ Я Вам пришлю оттиск, когда она выйдет - в январе. Получила от главн. ред. восторженное письмо. Не знаю, понимаете ли Вы всю величину этого события - принимая во внимание В МОЕМ ВОЗРАСТЕ перейти на другой язык??+13

Третье: статья (не книга) о сов. критике напечатана в Нов. Журн. в декабрьском номере ${ }^{414}$ Прочтите и напишите, что думаете. Это - первая часть, вторая будет в марте (не поместилось, слишком длинная). Я ее перевела на англ. и выступала в публичной лекции. Было хорошо. Затем на двух языках написала о «Бледном огне« Набокова. Тоже пойдет в печать. ${ }^{415}$ Вот Вам моя жизнь - с лета.

410 See note 402 to Berberova's letter of 18 September 1966.

411 Nebensache $($ German $)=$ side issue, minor point.

412 Simon Karlinsky, Marina Cvetaeva. Her life and art, Berkeley 1966.

413 Berberova, "Outcast," The New York Review of Books, 9 March 1967.

414 See note 404 to Berberova's letter of 18 September 1966.

415 See note 405 to Berberova's letter of 18 September 1966. 
Принимая во внимание все сие, я решила на две недели полететь в Порто Рико (первая половина января, когда у меня каникулы) - купаться и загорать. Жизнь здесь интересная, полная интересных людей, всяких событий и т.д. - иногда кажется, что Принстон - пуп земли.

Многое хотелось бы Вам рассказать, но нет ни времени, ни места. Надо исписать 12 страниц. Скажу только вот что: я хочу поехать в Европу на два месяца всего, чтобы повидать друзей, и Вас в том числе. Планы мои сейчас п р и б л и з и т е л ь н ы, но через два месяца все должно быть выяснено. Сейчас мне кажется, что будет так: полечу в Лондон в начале июля, пробуду там 2 недели, затем 2 недели в Париже. С 1-го августа весь месяц могу шляться куда угодно и 1-го сент. полечу обратно в Америку. ${ }^{416}$ Значит, подумайте, не могли бы мы на недельку встретиться где-нибудь в августе, м.б. в Германии, в тихом (если такое есть) месте, где нет дождей, или в Швейцарии (Цюрих?), или в Италии. В Париже суетно и по-моему не так уж симпатично. Я и Грете написала, что хотела бы съехаться с ней в августе (теоретически - 4 недели для 4-х дорогих друзей).

Я Вам посылаю простой почтой библиографию статьи моей в Нов. Журнале. Из нее Вы узнаете, как я теперь работаю - как зверь.

Я в переписке с милейшим Д.Е. Максимовым. 417 Знаете ли Вы его? Пожалуйста, если Вы до 1 июня будете в Ленинграде, дайте мне знать - я Вам дам его адрес, а также его «ученика« подопечного, моего гениального аспиранта, кот. теперь уехал на год в Ленинград. Переписку веду с Бабореко, кот. спец по Бунину. ${ }^{418}$ А с Орловым както все заглохло: он написал дурацкую статью о Ходас., Кузмине и др. в Вопросах Литературы, кн. 10. Читали? ${ }^{419}$

Гуля, не посылайте заказных писем. Это для меня слишком сложно. Ищите на домашний адрес или на Русский департамент Принстонского универ-та. Все доходит.

У меня был в гостях Евтушенко. ${ }^{420}$ Инициатива была его. Расскажу при встрече. Боже, какая была скука, и не было тем для разговоров. Он есть смесь Битлз и Уолта Уитмена, занят сентиментальными соб-

416 Berberova has evidently forgotten what she herself had told Rittenberg on 18 December 1966 about her summer travel plans, which now were completely different.

417 Dmitrij Maksimov (1904-1987), professor at Leningrad University.

418 Aleksandr Baboreko (1913-1999), literary scholar.

419 Vladimir Orlov's (1908-1985) article "Na rubeže dvuch ėpoch (Iz istorii russkoj poėzii načala našego veka)" appeared in Voprosy literatury 10 (1966).

420 Evgenij Evtušenko (1933-2017). See Berberova's letters of 14 May and 14 July 1966. 
ственными любовными переживаниями и поклонением Рильке. Самое интересное в его визите было то, что жена его хотела мне подарить какой-то медный крест, ${ }^{\mathrm{X}}$ от которого я отказалась с улыбками, сказав, что я принадлежу к тому поколению, для которого Ленин отменил закон Божий. Но они не поняли.

Обнимаю Вас и жду письма. Вы на пенсии? Вы преподаете больше? Счастливый человек!

Нина

${ }^{\mathrm{x}}$ не то на груди носить, не то на стенку повесить 
Дорогой Гуля, спасибо за письмо. Пишу Вам с большой просьбой: если возможно, повидать Дм. Евг. Максимова в Ленинграде и спросить его: 1. Получил ли он мое последнее письмо от 25 декабря? На него ответа мне не было. 2. Хочет ли он, чтобы я писала ему или лучше не надо? 3. Получил ли две порции книг, посланных ему отсюда: первая с книгой Карлинского о Цветаевой, а вторая - с Зеньковским. ${ }^{421} 4$. Как ему нравится мой студент Джон (он же Ваня)? ${ }^{422}$ Буду Вам очень благодарна, если узнаете ответы на эти вопросы. А кстати скажите ему, что его пластинку (подарок) я получила через другого америк. студента и наслаждаюсь ей, но прошу мне не посылать подарков, потому что это доставляет ему хлопоты. (Это не вежливая формула, а всерьез).

Гуля, я была поражена смертью Германа. Передайте Тане мои теплые чувства. ${ }^{423}$

Орлова статья в «Вопр. Лит.«, номер 10, просто г----. Столько лет ждать и сказать такие пошлости, и все такими штампованными словами! Но я конечно написала Орлову ласковое письмо, потому что так надо. Он чиновник и есть - Вы совершенно правы.

О Булгакове - не согласна с Вами. Мне было скучно. Булгаков - журналист и его «нечистое« отношение к слову меня коробит. Он не знает разницы между сценой и ареной, и вообще «грязен«, неаккуратен, небрежен. Конечно, политически это своего рода «явление«, но мне окончательно стали неинтересны политические явления (в литературе). Чорт с ними! Уважаю, но читать не могу. А наслаждаться - тем более. ${ }^{424}$

Здесь жизнь интересная, приезжают лекторы с разных концов земного шара, приходят книги на всех языках. Я полна энергии, чувствую себя как никогда - вот что значит уехать на две недели среди зимы в тепло. Для меня солнце - все. Даже мозг мой заряжается им, как батарея.

Мне пишут из Москвы, что дела там повернулись за последние 10 дней в скверную сторону. Это меня беспокоит, потому что начали

421 Possibly Vasilij Zen'kovskij's (1882-1961) Istorija russkoj filosofii 1-2, Paris 1948-1950.

422 John Malmstad (b. 1941), expert on Russian Symbolism, subsequently professor at Harvard.

423 Jurij German died on 16 januari 1967.

424 When it came to Michail Bulgakov's recently published Master i Margarita - as also was the case with Andrej Platonov's prose - Berberova had a blind spot. 
хватать людей вокруг одного центра (литературного). Слышали ли Вы что-нибудь об этом?

Гуля, как здоровье? Как самочувствие? Посмотрите, нет ли чего в книжных магазинах интересного. Расскажите о поездке, когда вернетесь. Я буду ждать.

Обнимаю Вас, мой дорогой.

Нина 
Драгоценный Гуля, сейчас получила Ваше письмо и отвечаю сразу, потому что взволнована чрезвычайно: Дм. Евг. М. сказал Вам, что я что-то антисоветское совсем недавно напечатала в Зап. Германии? Но Я НИЧЕГО НЕ ПЕЧАТАЛА В ЗАП. ГЕРМАНИИ с 1962 г. - когда в Мостах была опубликована моя пьеса!! 425 Я не участвовала в «Гранях « (кажется только раз, в 46 или 47 г.г.), и в Мостах (1958-62) ничего политического не печатала. ${ }^{426}$ Что это значит? Спутали ли меня с кем нибудь или злостно на меня ему клевещут? Я умоляю Вас, если только это возможно, дайте ему знать, что «его сведения о Н. Б. в Зап. Германии неверны«. Вообще я печатаюсь только в Нов. Журнале: в №№ 85 и 86 напечатана моя статья о сов. критике. ${ }^{427}$ М.б. ЭТО? Прочтите ее, кстати, и увидите, что там я оптимистически и иногда восторженно говорю о сегодняшнем литер. дне в Сов. Союзе (Глеб Струве мне писал, что «протестует«). Гуля, прошу Вас выяснить, что это такое. Я сейчас, будучи в переписке с дорогими мне друзьями, никогда бы не подумала даже вести какую-то политическую полемику с режимом!! Каково мне сейчас думать, что Макс. и др. считают, что а их «подвела«!

Ваше письмо было, как всегда, необычайно интересно. Книгу Мейснера я выписала давно, но она еще сюда не дошла. ${ }^{428}$ Мне пришла в голову мысль: а что если Тане приехать буд. летом в Швейцарию и нам обоим там тоже свидеться и втроем в тихом месте провести какие-то дни? Подумайте об этом. А. Белого стихи в Б. Б. Поэта я купила 4 экз., обезумев от страха, что их опять 45 лет не будет (как та старушка, кот. после войны купила 40 катушек черных ниток). ${ }^{429}$

Здесь живу интенсивной и интересной жизнью: друзья, книги, собственные литер. дела. Книга переводится; Глеб С. ${ }^{430}$ торгует ее для русского издания - трудный он человек и не знаю, выйдет ли что. Было у меня в прошлом месяце два публичных выступления, лекции по литературе

425 See note 327 to Berberova's letter of 27 May 1962.

426 Berberova is slightly mistaken. What appeared in Grani 12 (1951) was her article "Vladislav Chodasevič."

427 In "Sovetskaja kritika segodnja," which is based on extensive source materials, Berberova shows how Soviet Marxist literary scholars struggle with contradictions after having been influenced by Western theories to recognize the experimental prose of writers such as Belyj and Remizov. The Socialist Realist dogmas are disintegrating.

428 Dmitrij Mejsner (1899-1980), Miraži i dejstvitel'nost'. Zapiski émigranta, Moscow 1966.

429 Andrej Belyj, Stichotvorenija i poemy, Moscow-Leningrad 1966 (with a foreword by Tamara Chmel'nickaja).

430 Gleb Struve. 
в др. университетах, а на прошлой неделе ездила в Вашингтон, там был съезд один, в кот. я принимала участие. В конце апреля лечу на 4 дня в Калифорнию. (Машинка шалит, но нет времени пойти и отдать ее в чистку). Весна пришла, и я рада. Не могу без солнца жить.

Гуля, напишите поскорее, я ужасно расстроена делом с ДЕМ. ${ }^{431}$

Обнимаю Вас нежно и дружески.

Нина

431 Dmitrij Evgen'evič Maksimov. See Berberova's letters of 30 April and 11 May 1967. 


\section{PRINCETON UNIVERSITY \\ PRINCETON, NEW JERSEY 085430}

Slavic Languages and Literatures

30 апреля 1967

Гуля, я просила Вас написать более подробно, откуда пошел слух, что я что-то напечатала в Германии, а Вы мне на это отвечаете совсем неудовлетворительно, словно это какие-то пустяки! Это очень серьезно; Д.Е.М. ${ }^{432}$ мне написал ласково, чтобы я ему больше не писала. Это для меня удар. Нельзя ли все таки выяснить это недоразумение?

Булгаков (Мастер и Марг.) по-моему вещь написанная журналистом, небрежным к языку, т.е. к материалу, и мне совершенно не понравилось. Булгаков по-моему ужасно «раssé«.

Почему Вы пишете, что не знаете «сможете ли выбраться в августе«? В каком августе? Я Вам писала, что в этом году в Европу не приеду. Я уже писала Вам, что моя книга выйдет в 1968 г. Прочитали ли Вы мою статью в 85 и 86 кн. Нов. Ж. ${ }^{433}$ Ржевских видела недавно. Вчера вернулась из Калифорнии, куда была приглашена на одну конференцию.

H.

432 Dmitrij Maksimov.

433 "Sovetskaja kritika segodnja." 
Мой дорогой Гуля, простите, если я огорчила или обидела Вас. Я сейчас только могу написать несколько строк, потому что идут экзамены и я не могу выкроить времени для себя. Скажу только, что я впала в панику, думая, что ДЕМ попадет из-за меня от начальства, когда я ни в чем не виновата, как я и писала Вам. Он мне близок и дорог - среди всех других корреспондентов. И он друг моего друга, кот. может быть навестит Вас в Стокгольме - Вы разминулись с ним в Ленинграде.

Обнимаю Вас. Ваши письма всегда интересны и я надеюсь, что Вы благополучны и здоровы, и опять будете мне написать.

Нина 
Дорогой Гуля,

передо мной Ваше письмо, последнее, оит 27 июня. Ровно два месяца я не писала Вам. Письмо после ленинградской поездки, очень интересное, как всегда, и мое молчание непростительно. Где Вы? Здоровы ли? Где отдыхаете летом? Или не отдыхаете? Что вообще делаете? Преподаете ли еще? Собираетесь ли в Ленинград опять?

Я осталась в Принстоне все лето и работаю по 5-6 часов в день над английским переводом моей книги. Переводчик хороший, но текст очень трудный, и я помогаю ему во всем. Дело идет к концу. Русское издание тоже выйдет, но где и когда пока не знаю. Есть три русские возможности, которыми надо бы заняться, но я так погрязла в английском переводе, что до русского издания еще не дошла. Лето у нас было дождливое, грозы каждый день и солнца мало. Но мне все это было безразлично, т.к. времени все равно не было пользоваться хорошей погодой.

Из России вести идут дурные. Переписка моя с тамошними людьми затихла - до января, когда юбилей закончится и можно будет опять питать какие то надежды, а то сейчас никому ни до чего. Что с Вознесенским - тоже неизвестно, с тех пор как он написал свое письмо в Союз. М.б. Вы что-нибудь слышали. Книги туда не доходят, русские - вовсе, английские - едва-едва.

Кое-что пишу в американских журналах, ездила читать публичные лекции в штат Нью-Йорк и в Калифорнию. Навещала друзей в Нью-Хейвене. Но главным образом сижу за письменным столом. О многом хотелось бы поговорить. Когда мы увидимся? Прошу Вас меня не забывать и прощать мне мое молчание. Грете, между нами говоря, я не писала больше года.

Гуля, у меня к Вам просьба, пожалуйста, когда будете мне писать пришлите мне короткую (десять строк) справку о себе самом: когда родились, когда из России, какое образование, что делали до 1939 г. и что - после. У меня в книге будет приложен «альфавитный указатель« - не менее 50 страниц, и все упомнянутые в книге будут там «объяснены«. О Вас есть страница - самая теплая и дружеская, какую только можно выдумать.

Обнимаю Вас. 
Дорогой Гуля, простите, что не ответила на Ваше письмо. Занята ужасно: курсы, шесть диссертаций, за которыми слежу, и огромная корреспонденция (около 15 писем в неделю пишу), а тут еще приехал мой «аспирант«, кот. 10 мес. был в СССР и потом три месяца в Лондоне. Привез потрясающие вещи, микрофильмы и копии из архивов. Не думала, что доживу до такой минуты, что прочту такие документы (1905-1921)! Кроме того, заканчивала английский индекс моей книги (500 имен, 85 страниц, настоящая энциклопедия). На рождестве буду делать русский - по-другому.

Спасибо за данные о себе. Но мне кажется они слишком общие. Ведь вот Вам оказия первый и последний раз (может быть) объяснить, что такое выборгское Содружество - о кот. никто ничего не знает, и кот. пропадет абсолютно, как камень в потоке, если Вы не скажете ЧТО это такое было, КТО там был, КОГДА, и пр. и пр. А Вы ничего не говорите! Как то кустарно и очень мило - в двух словах, не «академично«. Почему? Не сердитесь. Ведь от Содружества никого не осталось, и ни одна душа на всей планете не знает, что это такое - в том числе и я. ${ }^{434}$

Тарсис на меня производит впечатление махрового дурака, но раз Вы пишете что он «честный«, я Вам верю; судя по тому, что я читала о нем и его - он странный человек. Знаете ли Вы, что он был вывезен из СССР Виктором Луи, коммунистом и чекистом, женатым на крупной английской коммунистке, и первые недели в Англии жил у ее родителей?? Это известие (абсолютно достоверное) произвело на меня довольно сильное впечатление. ${ }^{435}$

Все Ваши письма, дорогой Гуля, интересны, и если я не отвечаю, то только потому, что нет времени, а иногда и время есть, но нет сил. Здесь совершенно провалилась книга Светланы Сталиной, она на бестселлер листе только-только появилась на пятом месте, и сейчас же съехала на шестое. Слава Богу, ее подчистили переводчики - это был настоящий истерический плач «с повторами«, кот. в США никто уже давно «не кушает«. ${ }^{436}$

В Принстоне в это время года (как впрочем 9 мес. в году) рай земной. Дивная листва всех цветов, солнце, дома тепло и уютно, много

434 See my introduction, 2-3.

435 Victor Louis (pseud. of Vitalij Lui, 1928-1992), Russian-British journalist residing in Moscow, obviously connected with the KGB.

436 Svetlana Alliluyeva (Allilueva), Twenty Letters to a Friend, New York 1967. 
работаю, слишком много, хочу удрать в январе на две недели на юг. Много интересных людей вижу, и книг читаю. И о многом хотелось бы с Вами поговорить. Гуля, может быть у Вас есть деньги, чтобы приехать сюда и пожить две недели около меня? И посмотреть НьюЙорк? И вообще?.... Подумайте об этом.

Обнимаю Вас. 
Дорогой Гуля, не сердитесь на меня: у меня так разрослась переписка за последние годы, что я просто НЕ МОГУ успеть отвечать на все письма. Вы знаете, как я люблю Вас и Ваши интересные письма, но я не в силах регулярно писать. Скажу Вам: я пишу около 15 писем в неделю, и это, поверьте, очень много.

Получила все Ваши письма, и последнее о поездке в Ленинград. На душе моей очень все смутно - после процесса Гинзбурга и после новостей, которые регулярно до меня доходят разными путями. ${ }^{437} \mathrm{~B}$ сентябре опять мой «аспирант« едет на 6 месяцев. Каждый год у меня такая победа и конечно - громадный успех. Ведь только 50 человек едут со всей Америки, и непременно один из них - мой. У меня сейчас 6 диссертаций, за кот. я слежу. Это - рекорд во всех смыслах, и меня видимо собираются здесь держать, несмотря на возраст, до Морковкина Заговенья.

Книга выйдет в англ. переводе (очень хорошем) в этом году, осенью, и вероятно к Рождеству - по-русски. Я сделала 100стр.алфавитный указатель, настоящая энциклопедия (нечто вроде вынесенных в конец подстрочных примечаний). Все это берет время. Новый курс тоже съедает часы и дни. Словом, занята ужасно. Но не жалуюсь, потому что живу интереснейшей жизнью, каждый день приносит что-то новое, люди кругом замечательные, живу «в своей сфере«, читаю много (по специальности, конечно, давно не читаю романов), встречаюсь с амер. критиками, пишу регулярно в амер. литер. журналах. И книгу мою ждут.

Геннадия Фиша, о кот. Вы пишете, я хорошо помню. Вы спрашиваете, почему в зарубежье не издают Сологуба? Только-что вышел по-русски в Германии «Мелкий бес«. ${ }^{438}$ Только что вернулся сюда Ник. Набоков (композитор, кузен В.В.) и рассказывает много интересного о Ленинграде и Москве. ${ }^{439}$ Я почти (временно) прекратила писать кое-кому туда, боясь за них ужасно.

437 On 12 January Aleksandr Ginzburg (1936-2002) was tried and sentenced in Moscow to five years of hard labor for having compiled a record of the 1966 Sinjavskij-Danièl' case.

438 Berberova appears to be mistaken here. Fedor Sologub's Melkij bes was republished in 1966 by Bradda Books (Letchworth, Hertfordshire).

439 Nicolas (Nikolaj) Nabokov. See note 394 to Berberova's letter of 14 May 1966. 
Вы спрашиваете меня, не буду ли я в Европе этим летом? Я еще не знаю ничего, в зависимости, когда будут корректуры книги. Мож. быть съезжу на месяц в Лондон, и затем побываю в Париже. А больше - не смогу. Все это решится весной.

Обнимаю Вас, Гуля дорогой, и всегда Вас помню дружески и тепло. Не обижайтесь, когда молчу.

Нина 


\section{PRINCETON UNIVERSITY \\ PRINCETON, NEW JERSEY 08540}

Slavic Languages and Literatures

028 East Pyne

23 апреля 1968

Дорогой Гуля, Ваше письмо вчера меня поставило втупик. Почему такой официальный тон? Имя и отчество? «Простите великодушно«, «боялся докучать« и т.д. Что это? Надеюсь, что Вы по-прежнему мой друг и не остыли ко мне.

Здесь много интересной работы. Книга моя, как я Вам писала, выходит осенью. 100 страниц (на машинке) одних примечаний! Русское издание вероятно будет выпущено в этом году.

Мне бы хотелось знать о Вашем здоровье, и Ваших поездках в Ленинград, о том, что Вы думаете о тамошних событиях ${ }^{440}$ Очень все звучит мрачно и печально, не правда ли? И как плохо стали писать там! Если перейдут на электронику, то никто и не заметит - машина будет делать литературу может быть даже лучше?

Пожалуйста, позвоните Грете и спросите ее, почему она мне не пишет?? Она всю осень писала мне упреки, я послала ей перед рождеством длинное письмо, но ответа не последовало. Никакого диалога у нас давно уже нет. Странно!

Пишите мне о себе. Привет.

Нина

440 Berberova's meaning is unclear - she probably refers to the increasing number of trials of "dissidents." 


\section{PRINCETON UNIVERSITY}

\section{PRINCETON, NEW JERSEY 08540}

Slavic Languages and Literatures

028 East Pyne

25 мая 1968

Милый Гуля, получила Ваши письма - оригинал и копию. Не беспокойтесь, все доходит. Получила и Ваше письмо к Грете. Не хочу Вас вводить в подробности, но все-таки считаю, что Вам, как моему другу, я обязана что-то сказать про нее и ее странное поведение. Это, конечно, останется строго между нами.

Раз в год, в последних трех лет, она вдруг начинала бомбардировать меня письмами - еженедельно. Я отвечала (под Рождество, обычно) длинным письмом по-немецки. После этого наступало полное молчание. Через шесть месяцев я запрашивала коротким письмом почему она не отвечает на тьму вопросов, которые я ей задала? На это приходило письмо, что она н и ч е г о от меня не получала!!! Через год начиналось то же самое. В последний раз это было осенью (1967 года), и я в начале декабря послала ей опять длинное письмо. Теперь она отвечает, через Вас, что она н и ч е г о от меня не получила! Как Вы это объясняете? Для меня есть только одно объяснение - склероз мозга. Пишу я на все тот-же адрес, и доказательство, что письма доходят нахожу в том, что она на мой запрос в 67,66 и 65 году ответила. Как это понять по-вашему? Я в совершенном недоумении.

Я очень беспокоюсь из-за парижских событий. ${ }^{441}$ Ехать в Европу мне совсем не хочется. Я буду все лето в Принстоне, где рай, охлажденная библиотека (где у меня кабинет), друзья, работа и т.д. Готовлю на будущий год семинар по структуральной поэтике - без этого здесь нельзя, теперь это всюду необходимо, даже в СССР есть замечательные статьи по этим вопросам, и совершенно новая терминология (в связи с кибернетикой).

Пишите мне, Гуля дорогой. Кланяйтесь Ленинграду - где очень кажется неуютно. Напоминает 35-ый год.

Обнимаю Вас.

Нина

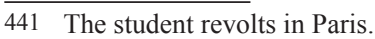


1 августа 1968

Дорогой Гуля, спасибо за то, что связались с Гретой Герелль, она тотчас же мне написала, при чем призналась, что в ноябре прошлого года получила от меня длинное письмо (а у меня лежит ее письмо от декабря, где она пишет, что год обо мне не слышала!!). Я ей ответила, но она опять молчит. Ни на какие вопросы она не отвечает, а всегда жалуется на ужасную свою жизнь в ужасной Швеции, и на XX век, и на все вообще. Это совершенно до меня не доходит.

Я давно о Вас ничего не слышала. Ужасы на дорогой родине (и в Чехии) дошли до температуры кипения. Много было интересных встреч за последнее время, и я мечтаю о многом Вам рассказать в будущем году: хочу приехать в Париж, пожить в Лондоне, и опять «смотаться« в Венецию.

Сидела 2 недели над английскими корректурами моей книги, кот. в декабре выходит. Этого здесь ждут, как события, и я начинаю важничать. Фотографии, неопубликованные документы, кое-какие исторические «бомбы« (о масонстве) и пр. - все там будет, но главное будет «алфавитный указатель имен« - целая энциклопедия за 50 лет! Данных о людях, умерших в эмиграции, или в концлагерях, или вообще исчезнувших - нет нигде, но я нашла почти все даты, и это будет настоящая энциклопедия. Как пример: вообразите, что художника К.А. Сомова нет нигде. Я нашла его в одном немецком справочнике. Память у меня очень хорошая, но все-таки я не помнила, умер ли он в 38 или 39 году - а сама была на похоронах!!442

Как Вы? Что делаете? Почему не пишете о себе? Были ли в Ленинграде? Какое впечатление вынесли? Как здоровье? Не будьте как Грета, ответьте на все вопросы! Знаете ли Вы журнал «Байкал«? Читали ли Белинкова об Олеше? Вчера я говорила с ним по телефону. 443

Черкните мне, какие у Вас планы на зиму? У меня миллион всяких всяких проектов, к сожалению в сутках только 24 часа. Нельзя ли где нибудь прикупить времени? Дорого дам.

Обнимаю Вас,

Нина

442 The artist Konstantin Somov (b. 1869) died on 6 May 1939 in Paris.

443 Arkadij Belinkov (1921-1970), defected to the West in June 1968. Earlier that year he had managed to publish a couple of chapters from his Jurij Oleša. Sdača i gibel' sovetskogo intelligenta in the journal Bajkal 1-2. It led to the closure of the publication and the dismissal of the editor-in-chief. Belinkov's criticism of the Soviet intelligentsia's capitulation exemplified by Oleša could not be published in in its entirety until 1976, posthumously, in Madrid. 
31 августа 1968

Мой дорогой Гуля,

так значит Вы считаете меня чем-то вроде жандарма: писать о книгах не «моего« ума дело! Вот так дружба! Выходит, что я запрещаю Вам писать о том, что Вам интересно. Как Вам не стыдно! Вы непременно хотите со мной поссориться! Но это Вам не удастся. Уже много раз у Вас это просто не выходило. Не выйдет и теперь.

Грета пишет мне, что занимается по-английски для того, чтобы прочесть мою книгу. Я была ужасно этим тронута. Впрочем, она, конечно, английский знает. И только подновляет его. А Вы? Русское издание то ли будет, то ли нет. По правде говоря - для кого?? Набоков ждал с Лолитой кажется 6 лет....

Белинкова я видела и имела с ним три длинных разговора. Есть в США люди, которые ему будут «гармоничны«, но не среди интеллигенции. Он мечтает о таких вещах, о которых в 20 -х г.г. мечтали у нас генералы Туркулы и прочие. ${ }^{444}$ И это - культурные тамошние люди. Чехия конечно подлила ему масло в огонь. Он будет преподавать в Йеле. Я, по праве сказать рада, что не у нас.

Раковый корпус прочла. 445 Эстетического наслаждения мне эта книга не доставила, но из нее я узнала интересные вещи, что, например, в госпиталях нет тряпок, и многое другое. Булгакова я читать абсолютно не в силах: небрежное отношение к СЛОВУ и журналистика прет из каждой строки. ${ }^{446}$ А уже спор Бога с Сатаной - просто невыносим. Кому это нужно? Чудес не бывает. И я их не требую. Но когда время ограничено, то я (живя в свободной стране) слава Богу НЕ ОБЯЗАНА читать то, что мне кажется неинтересным. Все меньше читаю романов, все больше антропологию, политику, историю и критику. Готовлю новые курсы. Ездила купаться на неделю к морю. Вообще живу хорошо, организованно (!) и окружена молодыми, умными мальчиками и девочками.

444 The Russian émigré officer Anton Turkul (1892-1957), of Moldavian origin, joined the Nazi-supported ROA troups during WWII.

445 Aleksandr Solženicyn's Rakovyj korpus was published in Paris, London and Frankfurt am Main in 1968.

446 Michail Bulgakov's Master i Margarita appeared in the journal Moskva 11 (1966) and 1 (1967), then in Paris in 1967. See note 423 to Berberova's letter of 16 February 1967. 
Вы пишете, что никто не допускал оккупации Чехии. Здесь тоже кроме меня, которая ждала ее со дня в день. Потому что если есть воображение, то ясно, что СССР не может позволить себе роскошь распада, который ему грозит через 10-20 лет.

Не забывайте меня. Впрочем, Вы не забудете, потому что я буду Вам о себе напоминать: в июне 1969 г. мы встретимся либо в Париже, либо в Германии.

Привет.

Нина 


\section{PRINCETON UNIVERSITY}

\section{PRINCETON, NEW JERSEY 08540}

Slavic Languages and Literatures

028 East Pyne

5 октября 1968

Дорогой Гуля, письмо Ваше получила. Хочу написать только несколько строк - в это время года я всегда ужасно занята. Только что вернулась одна моя «аспирантка«, которая в Ленинграде видела Иду Наппельбаум. Она (аспирантка) привезла мне фотографию Иды, книгу ее и ее отца, и длинный рассказ о ее (Иды) жизни. Это было волнительно и восхитительно. ${ }^{447}$

Живется мне хорошо, работы много и она интересна. Книга скоро будет готова, жду верстку - последнюю корректуру. Третьего дня целый день у меня проторчал фотограф, сделал 42 снимка. Будет их продавать в здешние журналы. Надеюсь вышла красавицей. Не дай Бог в этой стране выглядеть бабушкой - это называется «гранмодер-имидж«.Если такой «имидж« случается, то женщине ходу нет. Лет 12 тому назад чудная пианистка приезжала - Майра Хесс. Сказали о ней газеты, что у нее этот самый «бабушкин имидж«, и карьера ее в США была кончена. ${ }^{448}$ Мне это не грозит. Но я могу выйти похожую на ученую собаку. Это лучше, чем быть похожей на бабушку, но не очень хорошо.

Интересно, что говорит Ваш друг Верт СЕГОДНЯ после того, как выяснилось, что наши отечественные монголы не уйдут из Чехии до морковкина заговенья? И что страна, видимо, будет «протекторатом«, каким была Польша у Гитлера. Согласна с Вами о Солженицыне. Прочтите в «Новом Мире« (№ 4 или 6?) рассказ Анатолия Кузнецова «Артист миманса« - не плохо, но Акакий Акакиевич до сих пор видимо в их жизни играет большую роль. ${ }^{449}$ Обнимаю Вас. Как здоровье? Пишите ПРО СЕБЯ побольше. Учу Вас этому годами, прошу, требую .... никаких результатов.

Нина

447 See note 270 to Berberova's letter of 1 September 1959.

448 Myra Hess (1890-1965), English pianist.

449 Anatolij Kuznecov's (1929-1979) Gogolesque story "Artist mimansa" appeared in Novyj mir 4 (1968). 
Дорогой Гуля,

я заказала билет на конец июня на «Елизавете Второй«. Я на этот раз еду «свободнее«, т.е. не планирую заранее и не заказываю комнат. Одно знаю: две недели июля и две последние недели августа я буду - в Париже и в Лондоне. Между 15 июля и 15 авг. Я буду свободно «циркулировать«, и моя мечта повидать дорогих сердцу людей. Мы могли бы съехаться в Париже (или в Германии, или в Италии). Я хочу поработать немного в августе в Британском музееи и встретиться с историком Н. Андреевым, побывать в Кембридже и Оксфорде. ${ }^{450}$ Даже не знаю, где буду в Париже жить - с одной стороны м.б. у двоюродной сестры (которая в мае потеряла мужа), а с другой - у подруги на рю Миромениль, у кот. я жила в 1965 г. А с третьей - просто в отеле. Сейчас еще рано думать об этом. Вы мне напишете, когда Вы будете в Париже - м.б. самое лучшее встретиться именно там?

Я во всем согласна с Вами в отношении Солженицына. «Первый круг« лучше «Корпуса«. ${ }^{451}$ Но и то и другое многословны до чрезвычайности. Многословие происходит от низкого уровня читателей - ты по первой фразе уже все понял, но надо разжевать для полуграмотных полуинтеллигентов, и вот он жует - так что просто невыносимо. Тем не менее, для меня он гораздо важнее и больше Пастернака, и вообще надо сказать, что (не в пример Франции, где нет почти никого), в «России« сейчас два замечательных писателя - Набокова и Солж. Соединение странное, но ведь и Россия - странная страна. Я не совсем понимаю, что Вы называете снобизмом? Об этом мы поговорим при встрече. Снобизм для меня - вельтаншауунг, «мод оф лайф«, анти-демократический уровень сознания, ведущий к стерильности и отверженности.

На переплете моей книги будет фотография, кот. Вы опять будете недовольны. Она - в стиле книги, и это очень важно. В книге нет нарциссизма - значит я не могу выглядеть красивой. В книге рассказывается про Первую войну - значит я не могу быть молодой. Но в фотографии есть «что-то«, и я ею довольна. Вообще переплет - элегантный. А книга выйдет (и будет Вам послана) только в феврале: индекс взял столько времени (более тысячи имен) что задержалась вся книга.

450 Nikolaj Andreev (1908-1982), prominent Slavist at Cambridge.

451 Solženicyn's novels $V$ kruge pervom and Rakovyj korpus. 
Почтение Верта к Сталину мне до того отвратительно, что я не хочу больше о нем (Верте) слышать.

Обнимаю Вас. Пишите. Пишите О СЕБЕ. Я даже не знаю, что Вы ДЕЛАЕТЕ - ведь делаете же Вы что-нибудь?

Нина 
Мой дорогой Гуля, сколько раз я у м о л я л а Вас никогда не думать, что я могу на что-то рассердиться или обидеться. Ей-Богу, мы выросли из этого уровня знакомства, как из детских штанишек. Я не писала Вам потому, что до 18 дек. у меня не было времени и я изнемогала от работы. Сразу после окончания семестра на меня напала Гонгконгская или какая-то другая инфлуэнция, я почти неделю пролежала. 3 января - я Вам писала об этом в свое время - я полетела во Флориду и вернулась оттуда третьего дня. Во Флориде, конечно, пера в руки не брала.

Внимая Вашим просьбам я устроила так, что буду целую неделю $\underline{\mathbf{B}}$ июне уже в Париже. Приеду 24-го. Сообразите, как и где мы могли бы встретиться.

Моя студентка, прелестная девочка, хорошо говорит по-русски, поехала прошлым летом в Ленинград и разыскала Иду Наппельбаум. Передала ей мною посланные вещи и привезла мне ее книгу и фотографии. Я написала Иде письмо в октябре. И, представьте себе, только сейчас получила, и даже не ответ, а скорее поздравительную карточку, из кот. однако я поняла, что она мое письмо получила. Это было для меня большой радостью. Гари Керн, ${ }^{452}$ другой мой студент, о кот. Вы пишете (в руки которого попал весь архив Лунца - через меня), пишет мне, что видит (помнящих меня, и я их хорошо помню) Лиду Харитон, Зою Никитину, ${ }^{453}$ Дусю Каплан-Слонимскую ${ }^{454}$ и др. Он скоро вернется и будет рассказывать многое. Но с Кавериным встреча была, как он пишет, неудачная - Кав. всего боится, смотрит подозрительно и помалкивает.

Благодаря рождеству и странной привычке советских людей посылать поздравления «с рождеством христовым« (кот. я совершенно не праздную по моей абсолютной анти-религиозности), я получила известия от давно молчавших моих корреспондентов. Один из Ленинграда переселился в Киев, т.к. «в Лен. ему нечего было делать« (!!!). Даже Орлов мне написал, но о Б. Библ. поэта, откуда его вышвырнули - ни гу-гу. Пока все, мой милый Гуля. Ваши письма всегда интересны, а если я молчу, то НЕ потому, что разлюбила Вас.

452 See note 386 to Berberova's letter of 6 March 1966.

453 Serapion Brother Nikolaj Nikitin's (1895-1963) wife.

454 Ida Slonimskaja (1903-1999), Serapion Brother Michail Slonimskij's wife. 
23 января (1969)

Дорогой Гуля, в догонку моему письму 2 дня тому назад: мне смогли переменить пароход на «La France« и я приплыву в Париж 17-го июня. Приезжайте в Париж в это время, проведем неск. дней вместе. Это мне кажется наиболее мудрый выход из положения.

$$
\text { О дружба! Это ты! }{ }^{455}
$$

Нина

$\overline{455}$ See note 61 to Berberova's letter of 15 December 1947. 
Дорогой Гуля,

оба Ваши письма получила. Моя книга будет готова, видимо, в конце марта, и я тогда же пошлюе Вам (но не воздушной почтой - она весит 40 пудов). В магазины она пойдет в конце апреля. Все делается «ан гран«, ${ }^{456}$ т. е. мне придется выступать по телевизии, давать интервью, сниматься, и т.д. Обложка очень замечательная. Я не то, что волнуюсь, а надоело ждать. Здесь предполагаются приемы в мою честь и пр. и пр. и пр. Все расскажу, когда увидимся.

18 июня утром я хочу, чтобы Вы позвонили мне по телефону: Лекурб 54-17. Я буду у моей кузины. Она, как я Вам уже писала, в майских событиях в Париже потеряла мужа в автомобильной катастрофе, и я проведу у нее во всяком случае неделю. В самых последних числах июНя я хочу из Парижа выбраться, а потом опять приехать числа 25го июЛя, взять кузину и повезти ее в Лондон, чтобы слегка развлечь музеями (она это любит и знает). 1 августа я перееду на 2 недели к моим друзьям под Лондон, - у них тоже были тяжелые переживания в прошлом году и они ждут меня с нетерпением. В Голландию я ехать, прямо скажу, не хочу. Так мне нечего делать, музеи я знаю хорошо, погода - сомнительная. Не знаю, сколько Вы останетесь в Париже, но я главным образом на этот раз стремлюсь в Лондон, где у меня оказалось больше людей, которых я хочу видеть, чем во всей Франции. Я также должна провести несколько дней в Библиотек Насиональ в Париже, и столько же времени в Британском музее.

Почему Белинков - «мой«? Я его знаю, это все. Трудный он человек и абсолютно глухой к западу, и языков не знает. Боюсь, не выдержит и потонет здесь в «русском супе«. Он многословен до ужаса, но они все многословные, даже Солженицын, кот. я считаю, вместе с Набоковым, большим русским писателем нашего времени. Посылаю Вам мою рецензию о двух его романах..$^{457}$ Писала ее, конечно, прямо по-английски. Печатаю вообще здесь довольно много. Завтра достану «Собачье сердце«. ${ }^{458}$ Очень надеюсь, что мне понравится. Но я не принадлежу к тем людям, кот. требуют, чтобы их друзья любили то же, что и они сами. Вы можете любить Булг., а я - нет, но мы будем продолжать любить друг друга.

456 En grand (French) $=$ on a large scale.

457 Berberova, "Solzhenitsyn's Grim Vision," Princeton Alumni Review, vol. 69 (1968).

458 Bulgakov's novel was published in London in 1969. 
Кленовский скучен. Скуки я не переношу больше ВОВСЕ. Ефимова прочту. ${ }^{459}$ Все в письмах Ваших было интересно. Обнимаю Вас.

Nina

459 Eventually, after the young Leningrad writer Igor' Efimov (1937-2020) emigrated, it was revealed that he was the author of much-discussed philosophical texts that were smuggled out of the Soviet Union. 


\section{PRINCETON UNIVERSITY \\ PRINCETON, NEW JERSEY 08540}

Slavic Languages and Literatures

028 East Pyne

4 апреля 1969

Милый Гуля,

книга вышла - и в одном экземпляре - у меня. Официально выйдет 23-го - тогда будут и объявления, и рецензии, и телевидение (интервью), и фотографии в журналах, и всякий шум... Делается все «ан гран«, ${ }^{460}$ и я трепещу. Вопрос стоит следующий: хотите ли Вы, чтобы я Вам отправила книгу, когда она выйдет? Если я ее отправлю в конце апреля, Вы ее получите в начале июня и не успеете прочесть до нашего свидания (606 страниц убористого английского текста, весьма не простого!), или Вы хотите ждать Лондонского издания (июль), кот. будет Вам препровождено немедленно, и Вы получите книгу в конце (или середине) июля? Это было бы вероятно проще. Сама перечитывала свой текст одиннадцать дней - полей в книге почти нет, и чтения в ней жутко много. Не говоря уже о 540 примечаниях (выделенных в конец). Пожалуй, она ни на что не похожа (русское), разве что на Бердяева «Самопознание«, потому что в ней много философского, современного, но конечно язык менее суконен, чем у нашего экзистенциалиста. Ответьте, что мне делать с книгой.

Набоков с Кончеевым говорил ведь только мысленно! А Вы пишете, как будто это было реально? ${ }^{461}$

Ваша

Нина

$\overline{460 \text { en grand (French) }}=$ on a large scale.

461 "Končeev" is the only contemporary poet who appeals to Godunov-Čerdyncev, the hero of Nabokov's novel Dar. 


\section{PRINCETON \\ PRINCETON, NEW JERSEY 08540}

Slavic Languages and Literatures

028 East Pyne

9 мая 1969

Милый Гуля, к моему удивлению сразу пришли два Ваших письма от 9 и 12 апреля!!! Вы однако не написали, вернетесь ли в Швецию до Парижа или нет. На всякий случай пишу Вам. 18 июня буду ждать Вашего телефона к Асе (моя кузина). Книга моя вышла, лондонское издание выйдет в конце лета. Никому в Европе не посылаю американское издание - слишком дорого, и долго идет почта.

У меня здесь 4 интервью по радио и два на телевидении. 183 экземпляра разосланы критикам. Все ужасно «ан гран« ${ }^{462}$ к чему мы не привыкли.

Одоевцеву не читала, только один отрывок, где она сидит на коленях у Мандельштама и слушает как он ей говорит о поэзии - прямо из своей давно напечатанной статьи!! ${ }^{463}$ Грюневальд (делающий такие ошибки) как-то меня совсем не интересует: зачем читать какие-то приблизительные исторические измышления, когда столько интересного издается кругом и ни на что не хватает времени. А уж авторов дорогой родины - просто стыдно читать. С января 1967 года - ни одной живой строки там не было. Советская литература становится похожа на физиономию Косыгина.

Обнимаю Вас. Больше писать не буду.

Нина

462 See note 460 to Berberova's letter of 4 April 1969.

463 Irina Odoevceva's $\mathrm{Na}$ beregach Nevy contains an extensive passage on Osip Mandel'štam. 
Дорогой друг Гуля, очень обрадовалась Вашему письму. Жаль, что я не могла присутствовать в Вашей милой холостяцкой квартире, когда была Таня, как бы я наслаждалась долгим разговорам втроем! Все, что Вы пишете, как всегда интересно, и столько тем, что на все я ответить не смогу. Во-первых - Верт. Вы пишете, что он был «честный« и «умный«. Вероятно по-своему Вы правы. Для меня явтор «Эспуар э крэнт« может быть либо умным, ибо честным. ${ }^{464}$ Честный дурак или умный прохвост - только эти две категории могли до августа 1968 г. «верить« в то, во что он верил. Но, конечно, бывают исключения, и возможно что он им был. Поэтому я умолкаю, и больше к нему не возвращаюсь.

Дело Анатолия Кузнецова невероятно на меня подействовало: я сужу о его «личной трагедии«. Видела его на Телевизии два дня тому назад. Он боится, что его убьют, и действительно м о г у т убить. Это совсем другой случай, чем Белинков, да и фигура крупнее. На меня он произвел впечатление разрушенного человека. Напишите, что Вы о нем думаете. ${ }^{465}$

Почему Вы решили, что я не люблю биографий? Пэйнтера биографию Пруста я конечно читала (два года тому назад) и очень она мне понравилась. ${ }^{466}$

Я читаю французские книги о масонстве и кое-что для освежения курсов. На будущей неделе уже назначила приемные часы. Греция была чудом из чудес, а затем - роскошная жизнь в Тироле, уютном и беззаботном. Но от Лондона и Англии вообще я ОПЯТЬ пришла в полный ужас. Еда и погода - невозможны. Конечно виновата не Англия, а я. Но можно ли вынести факт, что когда один день дождя нет, люди приходят в панику и боятся, что они сами, и вся их зеленая трава высохнут? Это меня просто убило. Если бы, к тому же, не горчица и кечуп, то вообще ничего нельзя было бы в рот взять.

464 Alexander Werth took his own life on 5 March 1969. His suicide appears to have had political implications. He could not accept the definitive end of hopes for the Thaw in the Soviet Union. Berberova found his attitude as expressed in his recently published Russia: Hopes and Fears (London 1969) to be hopelessly naïve. Here she translates the title of his book into French.

465 Anatolij Kuznecov defected in London in the summer of 1969. Berberova soon began a correspondence with him.

466 George D. Painter (1903-1978), Marcel Proust. A Biography 1-2, London 1959-1965. 
Гуля, пожалуйста, как только прочтете книгу мою - напишите мне. Или м.б. даже - как только ее получите. ${ }^{\mathrm{X}}$ Я знаю, что она уже вышла, но до меня еще не дошла. Послала ее кое-кому в Европу, но Ваше мнение - самое для меня важное. Здесь было три хвалебных отзыва и один - сдержанный. Обнимаю Вас.

Нина

x A также: был ли вложен Errata лист? 
Дорогой мой Гуля,

Вы написали мне два письма о книге, и я была ужасно тронута. Первое - при получении, второе - «по-середине«. Какой Вы добрый! Сейчас сразу хочу ответить Вам на три Ваши возражения: 1. Добужинский. О нем я говорю с большой любовью. Вы любите его как художника, а я - нет. Но ведь можно быть близкими друзьями и любить разное? Мы с Вами часто любим разное, и дружим. 2. Почему Вы пишете, что я говорю о Ренье презрительно? Что Вы!! Где это Вы прочли? Я говорю о том, что Мережковские вначале бывали в «свете« (Бурже, ${ }^{467}$ Ренье и т.д.). У меня н е т мнения о Ренье. Я думаю, он большой писатель, сейчас мне его читать трудно, так же, как и другого, вероятно еще большего, писателя, Реми де Гурмона. Но «презирать« я никак Ренье не могу. Ради Бога перечтите это место! 3. Зайцев, Когда я говорю, что он «тоньше« Бунина, я не говорю, что он «больше« Бунина. У Бунина несмотря на частые «совершенства« чувствуется дубоватость в его элементарной символизации (пример - пароход, на кот. плыл Господин, назывался «Атлантида« - это в наш то век! Уж слишком это клишеобразно!). 468 Зайцев символизирует гораздо тоньше, особенно в своем «расцвете« (вероятно 1914-1935), сейчас конечно он здорово «пал«. Зайцев (Вы будете удивлены, м.б.) у символистов научился многому (Белый называл его «обозная сволочь« - в тылу у сим-ов): ${ }^{469}$ он понимает и принимает безумцев, гомосексуалистов, истеричек, невротиков, падших людей, предателей и т.д. - понимает и сочувствует, и находит в себе отклик современному уродству, Бунин же стоит где-то между Тургеневым и Чеховым (по возрасту) и совершенно глух к безумствам нашего столетия... Но и это тоже - не мешает нашей дружбе, правда?

Я получаю много писем и даже люди приезжают смотреть на меня после прочтения книги. Но книга трудная, и не все ее могут прочесть. Русское издание... лежит в столе рукопись. Денег я не ищу. Но ползать на коленях ни у кого не буду. Подождем - увидим. Обнимаю Вас и еще

467 Paul Bourget (1852-1935), French Catholic novelist.

468 Ivan Bunin's story "Gospodin iz San-Francisko" (1915). Berberova was critical toward Bunin, an attitude that was certainly connected with what he revealed about her attempt to entice him to Paris during the German occupation.

469 In his review of the anthology Literaturnyj raspad 1908 Belyj had denounced Symbolism's epigones as a "camp-follower trash" (his emphasis). See his "Arabeski. Kniga statej” in Arabeski. Kniga statej. Lug zelenyj. Kniga statej (Moscow 2012), 225. 
раз говорю: тронута была очень и счастлива, что Вы все таки можете ее читать по-английски.

Нина

Гуля, я искала книгу Владимирова, кот. хочу непременно прочесть. В здешней библиотеке 7 Владимировых. Где книга издана? Как имя автора? Когда была издана? Здесь на англ. языке есть книга некоего Владимирова «The Russians« - мож. быть это она и есть ${ }^{470}$ Не забудьте ответить.

Вчера мне пришло письмо от Анатоля. ${ }^{471}$ Довольно нежное.

П.Е. Ковалевского не знаю (это священник?). ${ }^{472}$ Фотографии суперобложки у меня нет и никогда я ее не видела. Могу прислать еще одну суперобложку. Но это вряд ли Вас обрадует!

470 Leonid Vladimirov (pseud. of Leonid Finkel'štejn, 1924-2015), The Russians, New York 1968, in the original: Rossija bez prikras i umolčanij, Frankfurt am Main 1969.

471 Berberova was now corresponding with Anatolij Kuznecov, who wrote in exile under the pen name "Anatole."

472 Petr Kovalevskij (1901-1978), émigré historian, writer on religious topics. 
15 ноября 1969

Мой милый друг, я с Вами более согласна, чем Вы думаете. Да, французы себя судят очень странно. О Мопассане еще куда ни шло, но о многом другом - просто удивление, а иногда и раздражает это ужасно. Мопассан уж очень «буквален« - третьего измерения нет (Чехов в этом отношении настоящий «символист«). Сейчас люди ищут «перспективы« в книгах. Ренье не читают, по-моему, просто из-за м о д ы. Кто-нибудь откроет его, и пойдут читать. Конечно, есть в «декадансе« что-то очень далекое нашему времени. А что такое «декаданс«? Думаю, что это - равнодушие к моральным проблемам своего времени. А слово «моральным« следует здесь понимать в самом возможно широком смысле. Не думайте, что я стала требовать «ангажемана« (литературы обязательств - по-советски). Но есть что-то коробящее в «хамском« обращении, напр., с прислугой, во французских романах конца прошлого века - и мы начинаем их сторониться.... Или я не права? Думаю, кстати, что Ваше мнение о французах, как о самых «культурных« людях на земле, нужно бы пересмотреть. Что такое культура? В еде - да, они первые (и китайцы), но посмотрите, какими они СТАЛИ. Боюсь, что нет «самого културного народа«, и что англичане во многом могут их побить. А самый тонкий слой верхов интеллигенции США очень часто меня поражает именно в смысле культурности интеллекта. Одна черта «культурности« есть уважение к ц е н н о с т я м. Его у французов нет совсем.

О том, что книгу мою надо издать по-русски, мне решительно все пишут и говорят. Но я СТАРА ползать на коленях и просить всяких полуграмотных книготорговцев (торгующих одновременно и самоварами) ее издать. Посмотрим, что будет. Не спешу. Хотелось бы перед концом жизни знать, что она таки вышла на родимом наречии, но м.б. это недостижимо?... А что происходит в СССР? Там вышла книжка А. Кушнера хороших стихов - единственная радость за ТРИ года! (Когда будете у Тани, прочтите, купите, она третья уже и называется «Приметы«). ${ }^{473}$ Голубчик Гуля, зачем же посылать мне Владимирова? Сообщите только ГДЕ он вышел: в Европе? в СССР? в США? Библиотека ее купит немедленно. ${ }^{474}$

Обнимаю Вас. Занята ужасно. 3 января еду во Флориду отдыхать.

Нина

473 Aleksandr Kušner (b. 1936), former student of Professor Maksimov, a prominent name among the young Leningrad poets.

474 See note 470 to Berberova's letter of 24 October 1969. 
Дорогой друг Гуля,

получила книгу Владимирова и в два дня проглотила ее. Ничего подобного я никогда не читала. Не только он умен и сдержан, но он смотрит «прямо из времени в вечность« (не гадает на кофейной гуще!) и все, что он говорит, прямо попадает в точку. 20 лет тому назад, когда я «поняла« Эйнштейна, я увидела, что сов. власть должна будет пойти на известные уступки ученым, потому что «наука« разрушила марксистский детерминизм. Читая изредка «Вопросы коммунизма«, я пришла к заключению, что имеется в диамате тупик, и некоторые (но не все) т а м это сообразили. И теперь я читаю Влад. и вижу, что я была права. Если современная «технология« будет продолжаться, то будет «технократия«, и идиотам места на земле не будет. Вот моя формула - для XXI века - идиоты просто вымрут. Жестоко? Да. И пессимистично, и оптимистично одновременно. Знаете ли Вы, что не только в США, но и во многих других странах, появились молодые, которые «хотят жить как в XIII веке«? Так вот они и будут умирать в 34-35 лет, как было в XIII веке - без мыла, без анестезии, без прививок и т.д. То же можно сказать и об идеологиях. И по книге Владимирова Вы ясно видите, куда ведет «ерозия« и «стагнация«. Спасибо Вам за присылку книги. Хотите ли Вы, чтобы я Вам ее отослала обратно? Я заказала 2 экземпляра для себя и когда получу, могу Вам послать, потому что Ваш экземпляр я исчеркала (без карандаша никогда уже больше книг не читаю). И он теперь уже гуляет в других руках. Гуля, где Влад.? ${ }^{475}$ В Лондоне? Как бы я хотела написать ему и пригласить его, м.б., в Принстон: у нас здесь бывают «гости-лекторы«.

Сама я собираюсь быть в декабре «гостем-лектором - меня пригласили в Харвард. Еду туда на четыре дня в середине декабря. А в начале января - на благословенный юг. Здесь хорошо, стало холодновато, ясно и солнечно каждый день. Работы порядочно, но чувствую себя хорошо.

За неделю до Вашего письма с вырезкой, лондонский издатель прислал мне ее. Я не знала как реагировать - со мной чуть истерика не сделалась. Вот так дураки - такие скоро вымрут конечно! Хорошо, что они не назвали мою книгу «Итальянизмы мои«. Это было бы еще лучше. Все объявления были написаны на каком-то волапюке. И я просто решила плюнуть на них. Их главный литературный критик

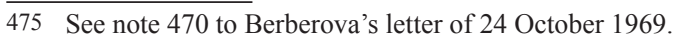


пишет (читаю раз в год) такими штампами, что когда я недавно прочла литературную критику написанную компютером, то я увидела, что ничего страшного в электронных машинах нет, и что они пожалуй даже оригинальнее, чем критик Русской Мысли.

С удовольствием прочла Ваши строки о верниссаже Греты. ${ }^{476}$ Говорили ли Вы с ней? Пожалуйста, узнайте, получила ли она мою книгу? Прочла ли? Ей книга была послана тогда же когда и Вам, но Грета никак не реагировала - не могу придумать этому объяснения. Спросите ее, ради Бога, что с ней? Почему она не откликнулась на «Итальянизмы«? И когда выйдет книга о ней самой? И получу я еe? ${ }^{477}$

О книге Набокова о Гоголе, я не согласна с Вами. Нам с Вами она не нужна, вероятно, но студенты в США ее очень любят и она действительно знакомит их с Гоголем. Что до страницы о пошлости, то это - шедевр, и мог бы войти в любую хрестоматию. ${ }^{478}$ Стихи Н. о Блоке я знаю, они конечно ужасны. ${ }^{479}$ Но это дела не меняет, по-моему.

Гуля, Вы пишете о грубости Гуля. ${ }^{480}$ Я ничего подобного в жизни не видела! С ним невозможно иметь дело, он просто в лицо человека ругает «матерно«. Видели ли Вы в моем указателе - в книге - заметку о нем? Быль молодцу не в укор, и я ничего против него не имею, но когда он теперь называет (подлеца) Луи Арагона ${ }^{481}$ «сталинским холуем«, то это по-моему немножко слишком. Немудрено, что и Зубова ${ }^{482}$ он оплевал.

Есть еще другой человек, который невероятно огрубел. Это Г. Струве. С ним тоже лучше не иметь дела. Единственное, что он написал мне о моей книге, это что я «недобрая«. ${ }^{483}$ Кстати, Марк Слоним, который со Струве не кланяется уже годы, упрекает меня в «сведении счетов« - я даже не поняла, с кем? ${ }^{484}$ Откуда такие христианские требования всепрощения? Подозреваю, что он упрекает меня в том, что я «разобла-

476 Gerell exhibited at Galerie Blanche in Stockholm.

477 See note 39 to Berberova's letter of 4 September 1947.

478 See note 315 to Berberova's letter of 18 December 1961.

479 Nabokov, "Na smert' Bloka."

480 Roman Gul' criticized Kursiv moj for omissions and errors in Novyj Žurnal 99 (1970).

481 Louis Aragon (1897-1982), left-leaning French novelist.

482 Valentin Zubov (1884-1969), art historian, founder of the Institute of the History of the Arts in St. Petersburg (1912), from 1925 in French exile.

483 Gleb Struve (1898-1985), émigré literary scholar, professor at UC Berkeley, wrote on the history of both émigré and Soviet literature. His review of Kursiv moj appeared in Slavic Review 2 (1970).

484 Marc (Mark) Slonim (1894-1976), émigré journalist and critic, also the author of a work on Soviet literary history. His critical remarks were published in Russian Review $1(1970)$. 
чаю« моих прямых врагов - сов. агентов в сороковых годах. Впрочем, м.б. он не их имел в виду... ${ }^{485}$

Вот Вам длинное письмо. Следующее будет не так скоро - экзамены, поездка, и пр. Когда Вы будете в Ленинграде?

Обнимаю Вас.

Нина

485 Berberova was criticized for having glossed over her life in occupied Paris, when she not only rubbed elbows with the occupiers and wrote her notorious poem, but also reportedly urged colleagues such as Bunin and Vadim Rudnev to join her. She attempted to rebut the criticism in an afterword to the first edition of Kursiv moj in Russian (Munich 1972). For a summary of Gul', Struve and Slonim's objections see Irina Vinokurova, "'Kursiv moj'v anglojazyčnom mire, ili Priključenija 'Italikov"” in Zvezda 4 (2016). See also Maksim Sraer, "Perepiska I.A. Bunina i N.N. Berberovoj. Vstupitel'naja stat'ja," I.A. Bunin. Novye materialy, vyp. II, Moscow 2010. 


\section{PRINCETON UNIVERSITY \\ PRINCETON, NEW JERSEY 08540}

23 декабря 1969

Дорогой Гуля,

отвечаю на два Ваши письма. Через неделю улетаю на Бахамас до 21 января. Поздравляю с Новым годом и желаю Вам счастья, покоя и здоровья. Все это - возможно, неправда-ли? Пожелания не такие уже неосуществимые.

Я тут «пожинаю плоды« моей книги: была в Харварде, дала вечер чтения, меня там заласкали. Весной вероятно полечу в Калифорнию на месяц - читать (по-англ.) ускоренный курс «Литература XX века« (русская). В будущем году приглашена в Колумбийский университет читать один курс (туда $1 \frac{1}{2}$ часа езды из Принстона, буду ездить раз в неделю). Словом, успех, - и пишу это только Вам, потому что никому об этом сказать не могу, подумают, что я хвастаю, а Вы не подумаете, потому что знаете, что я не хвастаю, а рассказываю Вам факты.

В Англии книга вызвала несколько замечательных рецензий. Не знаю, слыхали ли Вы о журнале ББС - Листенер. Так там была чудная статья обо мне, называлась «Поколение Набокова«. Я была очень счастлива, прочитав ее. ${ }^{486}$

Слушайте, что такое с Гретой?? Вы написали мне, что она по телефону сказала Вам, что она послала мне книгу с письмом (о моей книге). Действительно, неделю тому назад пришла книга, с очень приятными ее репродукциями и с надписью. Но никакого письма не было! Это повторяется теперь из года в год. Неужели моя книга, в кот. Грете и Миссис Асплунд ${ }^{487}$ отведено столько места, не вызвала у нее желания сказать мне несколько слов? И зачем врать?? Я начинаю подозревать, что у нее не все дома....

Обнимаю Вас, мой дорогой дружок. Напишу, когда вернусь домой с теплого моря.

486 “Nabokov's Generation," The Listener December 1969.

487 See note 20 to Berberova's letter of 20 June (1947?). 
4 февраля 1970

Дорогой Гуля,

спасибо за письмо. Каждое слово было интересно - о пребывании Вашем в Ленинграде. «Молодой человек«, кот. к Вам приходил Азадовский ${ }^{488}$ Я получила через одного человека (англичанина) из Англии пакет стихов Максимова. Он преувеличивает, что от меня г о д не получал писем - он ответил мне на мое письмо посланное в октябре 69 и на пакет фотографий (одна из них, как он писал, стоит на его письменном столе). Я написала ему вчера, также и Орлову, с кот. Вам было бы интересно встретиться: он только что прислал мне книгу «Б. Б. Поэта« (где он главн. редактор) - БАЛЬМОНТ! ${ }^{489}$ Замечательно сделано: выбор прямо чудный, и такая была необходимость в выходе сборника. Орлов, кажется, ждал пять лет, чтобы он вышел. Получила также от Берковского его «Литературу и театр«, тоже хорошо. ${ }^{490}$ И, наконец, от Максимова его «Брюсова«. ${ }^{491}$ Все три книги (т.е. огромное предисловие-введение Орлова к Бальмонту, Брюсов и «Лит. и т.«) многословны (как всегда) и избегают слов «символизм«, «метонимия« и пр. и пр. Вместо с-зм - употребляется «транспозиция«, и этот «термин« объясняется на целой странице; вместо метонимии говорится метафора, но и это тоже требует длинных объяснений. Все напоминает в общем старый одесский анекдот «Папа, это будильник«. Но тем не менее, я с огромным удовольствием прочитала все. О стихах Максимова: они формально неинтересны, но есть юмор, и есть боль, и есть видимо страшная потребность высказаться - и чтобы кто-нибудь это прочел и оценил. В данном случае, видимо, я. ${ }^{492}$ Так что из Англии пришел пакет копий (фото), и я написала ему всякие нежные слова.

Адрес Орлова на всякий случай - Ул. Желябова, № 1.

Итак, была выставка Сомова. А здесь я не могла найти (в конце концов нашла) дату его смерти для моего «указателя« в книге - ни в одной энциклопедии его нет!! А я была даже на похоронах!!

488 Konstantin Azadovskij (b. 1941) eventually became a prominent literary scholar and expert on German-Russian literary relations.

489 Konstantin Bal'mont, Stichotvorenija, Leningrad 1969 (with a foreword by Vladimir Orlov).

490 Professor Naum Berkovskij's (1901-1972) Literatura i teatr. Stat'i raznych let appeared in Moscow in 1969.

491 Dmitrij Maksimov, Brjusov. Poézija i pozicija, Leningrad 1969.

492 Maksimov's Stichi appeared posthumously in St. Petersburg in 1994 (with a foreword by Konstantin Azadovskij). 
Я вернулась с острова Бахамас, где было хорошо. Там с Луи Фишером случился сердечный припадок и его, как господина из Сан-Франциско, ${ }^{493}$ на лодочке с фонариком, переправили на другой остров, погрузили на носилках на аэроплан и помчали в Принстон, но не довезли: он умер в чужом госпитале в 50 милях от дома.

Обнимаю Вас.

Нина

493 The dying capitalist in Bunin's "Gospodin iz San-Francisko." 


\section{PRINCETON UNIVERSITY \\ PRINCETON, NEW JERSEY 08540}

21 марта 1970

Мой милый друг Гуля,

я с удовольствием пришлю Вам коллекцию рецензий о моей книге. Как только в мае будет посвободнее, я это сделаю. Английские были в общем умнее американских, но жаловаться я не могу - ругательных не было. С Гретой Герелль у меня отношения оборвались: она написала мне ужасное письмо, упрекая меня... я даже не поняла в чем - кажется в том, что я не знала, не любила, не понимала Гиппиус и теперь оклеветала ее. Я конечно думаю, что я Гиппиус любила (а она - меня), что на ЛЮБОМ языке не было о ней более теплых слов, чем мои о ней. Но Грета за последние годы по-моему стала не совсем нормальной, в ней развилась страшная ненависть и злоба к людям, думаю, что антропософия ее разрушила, а может быть и другие, более скрытые синдромы.

У меня к Вам просьба: пожалуйста когда увидите Максимова, скажите ему, что моя книга была послана ему в мае 69 года - он был первым в списке семи книг - ни одна ни до кого не дошла! Пусть он не думает, что я не люблю его, или забыла его. Пожалуйста, сделайте это! Тоже хочу Вас спросить, когда Вы едете в Л.? Не могли бы Вы навестить одного мне незнакомого, но пишущего мне человека, кот. мои студенты хорошо знают? Я напишу Вам в след. раз о нем побольше. Согласна с Вами о Бальмонте: его книга такое наслаждение - ранние стихи просто прелесть; это был праздник русской поэзии, фиэста, маскарад, игра, но сейчас почти щемит в душе, когда его читаешь.... ${ }^{494}$ Боже как грустна наша Россия - сказал П., когда прочел Гоголя. ${ }^{495}$ Книга Бальмонта была распродана в ОДИН ЧАС. И сюда не дошла (в магазины). Брюсов Максимова Вам бы оставил огромное наслаждение. ${ }^{496}$

У меня была две недели страшная инфекция между передними зубами и глазом, меня держали на кодеине и антибиотиках. Я ослабела и только-только начинаю возвращаться в нормальное состояние. Гуля, я

494 See note 489 to Berberova's letter of 4 February 1970.

495 Puškin's famous remark after having listened to Gogol"s reading of the first chapter of Mertvye duši , as reported by Gogol' himself in “Četyre pis'ma raznym ljudjam po povodu 'Mertvych duš,"' chapter XVIII of Vybrannye mesta iz perepiski s druz'jami.

496 See note 491 to Berberova's letter of 4 February 1970. 
еще напишу, а сейчас - пока закончу. Знаете ли Вы такого «историка искусств« Виталия Блоха (полагаю, наших с Вами лет, если не старше). Он мне написал из Парижа и прислал прелестную свою франц. книжку о Вермеере. ${ }^{497}$ Обнимаю Вас.

Нина

497 Vitale Bloch (1900-1975), art collector and scholar, author of Vermeer, Paris 1966. 
Дорогой друг Гуля, получила вчера Ваше письмо, а до этого открытку из Ам. Как бы я хотела бродить по Амстердаму, Брюгге и Генту с Вами, и конечно, - заехать в Гаагу! М.б. когда-нибудь мы это и сделаем. Это письмо будет состоять из просьб. Во-первых, пожалуйста, неситесь с Д.Е. Максимовым, когда будете в Л. Скажите ему от меня следующее: что стихи Кара́мова очень замечательные, и лежат у меня на столе, и я их перечитываю иногда. Что Джон ${ }^{498}$ будет в конце лета у него (м о й Джон, не английский, «его « $\left.{ }^{499}\right)$. Что моя книга (американск. издание) была послана ему год тому назад (и семи другим). Все копии были видимо конфискованы, потому что ни одна не дошла. В Л. имеется сейчас одна копия, она у Гены. Ее читают в очередь. Русского издания нет и пока не предвидится: русские ругают меня за то, что я не люблю царя и не верю в бога. И издателя у меня нет.

Это - во-первых. Во-вторых вот что: есть в Л. человек, с кот. я лично не знакома. Это - Ге́на (Геннадий) Шма́ков. Его адрес: Остоумова (так именно, без «эр«) 10, кв. 12. Это на Вас. Острове, далеко у моря. К нему надо поехать. У него жена, теща и маленький сын. Этот человек странный. К нему ездят все наши американские студенты и профессора, он говорит на четырех языках, культурен, переводил Жорж Занд (для денег, видимо), сейчас пишет исследование о франц. кино. Не служит. Жена служит где-то в библиотеке. У них бывают решительно все, «крем« Ленинграда (Гинзбург, ${ }^{500}$ Берковский, Орлов, Максимов, Кушнер и т.д.). Вы можете всех увидеть. Ему около 30 лет. Не только от него все в восторге, но и от жены, и от тещи, и от сына. Если Вы не хотите ехать к нему, то узнайте, какая у него репутация. Мне он подозрителен. Больше ничего Вам не пишу, но Вы понимаете. Хочу знать Ваше мнение о нем. (Насколько он опасен). Он мне пишет время от времени письма и зовет приехать.... ${ }^{\mathrm{X}} 501$

Летом я остаюсь здесь, в Принстоне, с некоторыми краткими выездами. Буду готовить курс - приглашена в Колумбийский университет будущей осенью, буду совмещать, и раз в неделю ездить в Нью-Йорк.

498 John Malmstad. See note 422 to Berberova's letter of 16 February 1967.

499 "His", Maksimov's John = John Elsworth (b. 1939), Belyj expert and prize-winning translator of Belyj, later professor at Cambridge.

500 Lidija Ginzburg (1902-1990), literary scholar in Leningrad, a member of the "Young Formalists" in the 1920s.

501 Gennadij Šmakov (1940-1988), poet, translator, ballet critic, emigrated in 1975 to the United States. 
Будущий год вероятно будет последним годом полной нагрузки для меня. На ближайших днях еду в Филадельфию, где буду читать лекцию о «Механизме «Бледного огнящ« (Набоков 1966). Обнимаю Вас. Напишите мне об отъезде в Л.

Нина

${ }^{\mathrm{x}}$ Один экземпляр моей книги в Л. - и тот у него! 
Дорогой мой Гуля,

месяц мы здесь кипим в котле. После вступления в Камбоджу начались протесты и демонстрации в университетах. Революцией не пахнет - для революции нужны две вещи: идеология и массы. Здесь нет ни того, ни другого. А анархию прекратит консервативное большинство страны. Конечно, все вокруг - против войны. Но люди «правеют« на глазах, потому что беспорядки и «протесты« всех не только утомили, но и возмутили. Сожгли чудные здания (модерн) в Йеле. Здесь у нас в общем было тихо или почти тихо. Из десяти студентов двое сказали мне, что у них «принципы« и они бастуют и приходить на последние лекции не могут. А восемь, боясь за свои репутации, тайно приходили ко мне домой и дослушали все до конца, но приходили отдельно и сидели по четыре часа, так что я к концу совершенно изнемогла. Теперь все кончилось. Европейцы здесь (как и я сама) понимают, что американские студенты - счастливейшие в мире люди и бесятся не совсем справедливо на всё и всех. Но американцы учатся этой истине только постепенно. Между прочим, была у меня в гостях одна девочка (франц. евр.) из Парижа, кот. сказала, что Сорбонна и остальное - собственно уже не существует, и высшее образ. во Франции разрушено. Так ли это?

Какие у Вас планы на лето? Я сижу здесь, занимаюсь приготовлением нового курса (для Колумбийского у-та) и вообще собираюсь тихо жить. Будущий год у меня - трудный, но зато и последний в смысле «полной нагрузки«, потом буду «диминуэндо« съезжать на три четверти, половину, а м.б. и четверть времени (и денег).

От Максимова получила письмо. До него дошла моя книга, ему ее переводят. Если увидите его, то скажите ему, чтобы он постарался дождаться: в 71 г. выйдет русское издание в Германии. Это меня радует очень. Что Вы думаете о книге Амальрика? ${ }^{52}$ Очень важно мне знать. Не забудьте написать об этом. У меня к сожалению нет времени читать «далекие« по темам книги - ни о Виардо, ни о разных других интересных людях, о кот. Вы читаете. Кстати, прочтите непременно письма Тург. к Виардо ${ }^{503}$ (теперь вышли в полном собрании писем) - там вынуто интимное, написанное по-русски, но оставлено - $\underline{\text { по- }}$

502 Andrej Amal'rik (1938-1980), Prosuščestvuet li Sovetskij Sojuz do 1884-go goda?, Amsterdam 1969.

503 Pauline García Viardot (1821-1910), French singer, Turgenev’s close friend. 
немецки. Видимо, господин Гарсиа немецкого не знал! ${ }^{504}$ Прочтите обязательно как Т. просил ее прислать ему лепесток цветка, который она весь день носила в туфле. Т., видимо, был самый законченный фетишист, которого себе можно представить. Гюнтера ${ }^{505}$ я прочту непременно, а Вы постарайтесь прочесть Маргариту Волошину, Ди грюне Шланге - там есть «сплетни«, которые Вы любите (и я тоже) - о том, как Л.Д., жена Вяч. Иванова, ${ }^{506}$ предлагала ей (когда В. была совсем молоденькой) жить в т р о е м с ней и Вяч. Ив.... ${ }^{507}$ Волошина еще была жива два года тому назад, и я послала к ней одного нашего молодого профессора, он нашел ее в параличе, в Нюренберге.

Знаете ли Вы Кавафиса? (Или Кавафи). ${ }^{508}$ Он умер в середине 30-ых годов и был замечательным греческим поэтом. Т.к. у меня есть греки знакомые (поэты и профессора), то я им на радость перевела два стихотворения. Как-нибудь пошлю Вам их.

(Машинка страшно постарела и я покупаю новую - эта уже никогда не омолодится).

Я удивилась и огорчилась, что Вы собирались на меня «рассердиться« за мои строки о Гумилеве (в книге). Я ведь называю его «большим поэтом« - каким всегда считала и считаю его. И не даю суждения о нем, как о человеке, а рассказываю ф а к т ы, которые состоялись в такой-то день, в такой-то точке земного шара. За что же тут сердиться? И даже если бы было выражено суждение, то разве можно сердиться за мнение? Эти что-то мне совсем непонятное. Вот если бы я сказала, что Ленин - бог, а Сталин - вроде Петра Великого, ну тогда за т ак о е мнение, которое выходит из самого глубокого основания человека, можно и раздружиться. Двум друзьям нельзя быть во всем согласным, - Вы, например, любили Верта. Разве я изменилась к Вам от этого? Я даже Вам никогда не сказала о том, что я думаю и думала о нем. (Самое скверное, что только можно думать). А утаивать фа кт ы по-моему есть ханжество.

Вы мне не написали, получили ли Вы наконец книгу Владимирова? Я ее послала Вам еще в феврале. Это меня беспокоит. (Он хорошо написал о ханжах).

504 Louis Viardot (1800-1883), French writer.

505 See note 512 to Berberova's letter of 25 June 1970.

506 Lidija Zinov'eva-Annibal (1866-1907), prose writer, Vjačeslav Ivanov's first wife.

507 Margarita Woloschin (Sabašnikova, 1882-1973), artist, once Maks Vološin's wife, published her memories under the title Die grüne Schlange (Stuttgart 1956).

508 Konstantinos Kavafis (1863-1933), Greek poet, posthumously famous. 
Обнимаю Вас. Пишите мне. Как здоровье? Не болеете ли чем? Я н и ч е м решительно не болею. И теперь - лето, жара, солнце печет: наслаждаюсь этим обстоятельством, не могу жить зимой совсем, ненавижу холод.

H.

С кем Вы дружите? 
Милый Гуля, получила Ваши два письма (после Ленинграда). Очень они были интересны. Хотелось бы мне побольше узнать о Г.Ш. - антураж, квартира, семья и пр. Если Вы помните, я в том письме, где в первый раз писала о нем, сказала Вам, что он «странный«. Вы вероятно поняли меня. Он принимает у себя в доме в с е х иностранных студентов, профессоров, писателей и т.д. Всех очаровывает. Это мне кажется с т р а н н ы м. Напишите мне, что Вы думаете об этом. Непременно. Времена там тяжкие. И страна (угрюмая, скучная, мрачная, темная) идет под гору, по-моему. Иногда ночью просыпаюсь и думаю об этом. Не знаю, так ли это, или мне это так кажется на старости лет.

Сообщу Вам новость, и знаю, что Вас обрадую: подписала контракт на русское издание «Курсива«, моей автобиографии! Представьте, знаменитый ФИНК-ФЕРЛАГ, в Мюнхене, кот. переиздал столько книг Белого и др. символистов, взял - и фото будут, и вообще книга будет прекрасного вида. Я конечно очень довольна, счастлива даже. Если опять будете в Ленинграде, скажите об этом Максимову. Знаете ли Вы Берковского? ${ }^{509}$ Хорошую он книгу написал, там есть очень замечательные страницы о Чехове («Литература и театр«). А Кушнера любите? Я - да.

По Вашему совету пошла я на «Ночь с Мод« ${ }^{510}$ - очень мило, но для меня 3 д е с ь, в Америке, такие вещи кажутся «сладкими« (и «библиотек роз $\left.\ll^{511}\right)$. Жизнь более трагична, страшна, и забывать об этом мне никогда не хочется (эскапизма вовсе в характере нет). То же могу сказать и о книге Гюнтера: очень рада, что Вы посоветовали мне ее прочесть, но.... «библиотек роз«! Я конечно пропускала места, где он говорит о папе-маме, иезуитах, немцах и т.д. Было страшно смешно иногда, я прямо хохотала, читая его домыслы о сыне Блока (никогда не было!) или разоблачения о Черубине де Габриак (давно известные). ${ }^{512}$ И все его неудачи (литературные) он понимает так, что ему не повезло.

509 See note 490 to Berberova's letter of 4 February 1970.

510 Ma nuit chez Maud (1969), widely-noted film by Eric Rohmer, the third in his series of six "moral tales."

511 "Bibliothèque Rose," pink-jacketed children's literature series launched by publisher Louis Hachette in 1853, still in existence.

512 Blok's friend Johannes von Günther's memoirs, Ein Leben im Ostwind, appeared in Munich in 1969. He refers to stubborn rumors that around 1920, Nadežda Nolle Kogan (1888-1966) bore Blok a son. The story about how Maks Vološin's mystification around the poet "Čerubina de Gabriak" (Ekaterina Dmitrieva Vasil'eva, 1887-1928) led to a duel in 1909 between Vološin and Nikolaj Gumilev had by this time been retold in detail by Sergej Makovskij in Na parnase Serebrjanogo veka, Munich 1962. 
Я вспоминаю, как мне одна очень милая русская женщина сказала, что мне повезло, что я написала столько интересных книг. Я даже оторопела. И спросила ее, что-же и Льву Толстому тоже повезло (да еще как!) когда он написал Войну и мир?

Вы говорите, что мне «нужно в Ленинград поехать«. Дорогой мой, после книги, когда я вернулась из Европы осенью, я получила неск. писем оттуда и поняла, что они зовут не на две недели, а навсегда: «Вы отсюда и не уедете, мы Вас так будем здесь любить...« Рисковать я не могу и не хочу. И вообще сейчас-совсем туда не тянет. (Между прочим, Г. Ш., как Вы вероятно поняли, не имеет постоянного заработка, но живет не плохо. Неужели жена содержит его, мать, сына и собаку???). (Машинка ужасна, но скоро будет новая).

Мне здесь чудно, в Принстоне. Погода божественная, свобода полная; готовлю понемногу курс для Колумб. Университета, на осень. Езжу гостить к друзьям - то туда, то сюда. Всё - на машине, конечно. Правлю я замечательно.

Я не знаю, когда будут корректуры и когда будет верстка книги. Но где-то в душе у меня зародился проект: либо для одного, либо для другого полететь в Мюнхен (м.б. к весне?) и попросить Вас приехать (2 недели?), и чтобы Вы тоже корректуру (или м.б. лучше - верстку?) прочли.... Это как-то робко вылупляется у меня в мыслях. Что Вы на это скажете?

Милый Гуля, отвечайте на мои вопросы, не выбрасывайте письма немедленно! Я Вас спрашивала о Вашем здоровье, а Вы не ответили. Бутерброд что-ли завернули в мое письмо? Стыдно!

Обнимаю Вас. 
Милый Гуля,

спасибо за оба письма! С огромным интересом читала их. Времена изменились т а м: кое-кому из моих амер. друзей в этом году не дали визы. Этого не бывало раньше. А недавно было совсем странное как будто из Кафки: есть у меня корреспондент, переписываемся уже четыре года. Живет постоянно «у мамы« в Киеве. Мой здешний друг повез ему мою книгу. Поехал, когда был в Киеве, к нему. Оказалось, что дома с таким номером не существует! Искал его полтора часа. Наконец, стал спрашивать. Сказали: не существует. Шофер такси подвернулся, ответил то же самое... Как Вам это нравится?

Третьего дня здесь на телевидении был потрясающий час: корреспондент-американец К., кот. недавно выгнали из СССР, привез ленты интервью с Буковским, ${ }^{513}$ Амальриком и Якиром. ${ }^{514}$ Я давно так не была «разрушена«, как этой передачей. Страна дичает совершенно, а те, кот. (во главе с Солж.) «не согласны«, те совершенно сломанные люди. Один рот Амальрика значил больше, чем три статьи о будущем сов. власти. Это люди, в которых почти ничего не осталось здорового - и это конечно понятно. Лагеря, сумасшедшие дома и т.д. сделали их такими. И вечный страх, и мания грандиоза перевернуть мир....

Недавно было письмо от Орлова. Пишет, что он «ушел« и что ему было горько, но иначе не мог. Замучили и его. Что будет с Г. Шмак., ${ }^{515}$ я не знаю. Возможно, что ему даром не пройдет его дружба с иностранцами. (Он критикует перевод моей книги. Интересно, что ТОЛЬКО РУССКИЕ критикуют англ. перевод книги! Англичане (в «Листенере«) и американцы здесь хвалили его!).

Здесь выходит новый том Бродского. Есть хорошие стихи. Он конечно лучший сейчас. Вы не думаете? Вы пишете, что Тане нравится мой разбор «Незнакомки «. ${ }^{516}$ Боже, как это было давно! И сколько сделано гораздо лучше (мною) в этой же области! Это был детский лепет. Я теперь работаю над «Даром«, где Наб. в прозе пользуется поэтическими приемами. Это очень меня захватило. ${ }^{517}$

513 Vladimir Bukovskij (1942-2019), prominent civil rights activist.

514 Petr Jakir (1923-1982), ditto.

515 Gennadij S̆makov.

516 Berberova comments in detail on Blok's poem "Neznakomka" in Alexandre Blok et son temps (Paris 1947), 81 ff. (Aleksandr Blok i ego vremja. Biografija (Moscow 1999), $96 \mathrm{ff}$.).

517 Vladimir Nabokov's novel Dar, New York 1952. 
Живу тихо. Сижу, работаю, читаю. Потом - мчусь по дорогам. Обожаю скорую езду (у нас можно ездить 65-70 миль на больших дорогах).

Ваша Нина 
Дорогой мой друг Гуля,

давно не писала Вам. Чудно провела лето. Ездила гостить к друзьям, у меня гостили, ездила купаться, сделала больше 5.000 километров с июня. (Кстати, о быстрой езде: ездить по маленьким дорогам опасно, ездить по незнакомым дорогам тоже. Ездить надо по автострадам. Езда - это спорт. «Смотреть по сторонам« не полагается и «любоваться пейсажем« тоже.) Погода была прелестная, Принстон летом очень хорош. Сейчас погрузилась в дела, но вижу ясно, что м о г у выйти в отставку в июне, и это меня безумно радует. Всю жизнь была человеком «свободной профессии« и мысль обрести опять свободу прямо кружит мне голову. Хочу будущей осенью провести хотя бы месяц в Испании. У нас здесь сейчас живет Вейдле, приглашенный в Принстон на три месяца. Они купили квартиру около Валенсии, и по его словам, там рай земной.

Для себя сейчас не работаю. Книга мне принесла кое-какие деньги, и кое-какие радости в смысле повышения по службе и др. Стала я важной. Перечитываю Пруста и читаю о Прусте - когда есть минута. Как я счастлива, что могу наслаждаться им, величайшим в нашем столетии.

О трех оппонентах сов. режима скажу, что Вы меня не поняли: я тоже восхищаюсь их смелостью и честностью, они - герои. ${ }^{518}$ Но больные герои. Это не властители будущей России. Это не государственные умы. Вот что я хотела сказать; я не судила их моральных качеств, которые для меня бесспорны.

Я не пишу «работу« о Даре Набокова. У меня курс «Введение в эмигрантскую литературу«, где я разбираю п р о б л е м ы (не даю обзора) и там 6 недель посвящены всем остальным, а 6 недель - Набокову. Я нашла в Даре и в Лужине ${ }^{519}$ и в Солус Рекс ${ }^{520}$ очень много п о э т и ч е с к и х п р и е м о в, и это страшно интересно.

Вы спрашиваете, знал ли Ренье русскую литературу? Я думаю, что не знал, а если и читал что-нибудь (вероятно очень мало), то не думал о ней, а если не думать, то это как бы и не читать, правда?

518 The physicists Andrej Sacharov and Valentin Turčin (1931-2010) and the historian Roj Medvedev (b. 1925) had asked for a democratization of society in an open letter to the Soviet leaders Leonid Brežnev, Aleksej Kosygin and Nikolaj Podgornyj.

519 Nabokov-Sirin's early novel Zaščita Lužina.

520 Nabokov's unfinished novel Solus Rex (1939-1940). 
Гуля, я никогда не воспринимала Вашего почерка, как «каракули« почему Вы так неуважительно пишете о себе? Я всегда читаю Ваши письма три раза: два раза когда получаю и в третий раз, когда отвечаю. Никаких трудностей у меня при этом нет.

Многие из наших мальчиков здесь (и девушек тоже), вернулись из CCCP, побывав там этим летом. Боже, какая мрачная страна! Некоторые хотят никогда туда не возвращаться. Аспирантов заставляли писать сочинения на тему «Мой любимый спорт«.... Между прочим, мне случайно попала в руки 1966 года книга «Молодой ленинградец« - рассказы и стихи (есть и Бродский, и Кушнер, между прочим). Я просто не могла придти в себя от изумления: 9/10-ых написано для детей или о детях, и тон большинства вещей какой-то сюсюкающий, кокетливо-искусственно-скромный, знаете, как девочка в шесть лет может сказать про себя: Ляля баиньки хочет. Вот все в таком роде. Даже страшно.

Когда я месяц тому назад была в Йеле, один мой старый приятель сказал, что о моей книге была в Нов. Журн. рецензия, где автор намекал, что я во время войны «воспела« Гитлера, и что эти стихи у кого то «хранятся«. ${ }^{521}$ Какая безграмотность! Эти стихи давно напечатаны в альманахе под ред. Иваска. Они ходили при оккупации (в трех версиях) по рукам. ${ }^{52}$ Я «Н. Ж.« полтора года не видела. Из русской прессы просматриваю Русскую Мысль - чтобы знать, кто умер. Увы, каждый раз (раз в 6 мес.) нахожу кучу знакомых мертвецов.

Обнимаю Вас, мой дорогой Гуля, пишите, не сердитесь, что я иногда молчу. У меня большая нагрузка - до января. Весной будет гораздо легче, а в будущем году мы съедемся с Вами.... в Испании.

521 See notes 480 and 485 to Berberova's letter of 22 November 1969.

522 See note 220 to Berberova's letter of 30 April 1954. 
Милый Гуля,

На этот раз - я полтора месяца ни гу-гу. Вот это называется молчанием! Вы наверное сердиты - на сентябрьское письмо я Вам не ответила. Оправдание у меня одно: работаю, как верблюд, преподаю в двух местах, хочу в последний год подработать немножко, выхожу в отставку в июне. И ужасно радуюсь этому! Хотя может прибавиться финансовых забот, но чувство свободы будет такое, какого 20 лет не было. Да, 20 лет в этом месяце как я тут, в США, и пора и отдохнуть. Пора и честь знать. Пока еще не знаю, что буду делать, - несколько есть проектов (писать, или во всяком случае - подготовлять кое-что); даже времени нет сосредоточиться на планах, на будущем годе. Считаю дни до 20 дек., когда начнется отпуск, а весной будет легче. По правде говоря, страшно замучилась в этом году...

Гуля, я кроме того еще завалена корректурами русской моей автобиографии. Ах, как по-русски все получается лучше! Я так счастлива, почти не меняю ничего, только исправила две-три ошибки (отчасти сделанные не по моей вине), да кое-что тронула в «биографическом указателе«. Издатель в большом энтузиазме, из СССР уже имеет (неофициальные, конечно) заказы. Все это радует меня.

Здесь Вейдле, который возвращается в Париж в середине декабря. Все ему здесь очень нравится. К сожалению, слишком поздно он приехал в Америку: еще в 1960 году я ему советовала устроиться в американский университет, но он, видимо, ждал, что его пригласят, и сам пальцем не двинул. Мне с ним очень бывает приятно. Мои студенты ценят его и ходят к нему с разговорами, но считают его «совсем посторонним старичком«.

Когда Вы в Ленинград? Что слышно? Здоровы ли Вы? Как пережили Солженицына и собираетесь ли его видеть, если он будет в Стокгольме? Видели ли воспоминания Над. Як. Мандельштам? 223

Обнимаю Вас. Пишите!

Нина

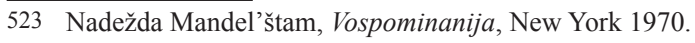


6 января 1971

Милый Гуля, с Новым годом! Как съездили? Новости, которые сюда к нам доходят от людей (американцев), возвращающихся из Москвы, очень грозные. Боюсь, международное положение может только осложниться, ввиду польских событий и конечно - Израиля. ${ }^{524}$ Как Вам жилось у Тани? Видели ли Вы кого? Видели ли Шмакова? Слышали ли что-нибудь о Бродском, Кушнере? Были ли у Максимова? Я в этом году ни от кого не получила поздравительных карточек, кроме как от Ш. ${ }^{525}$ - он видимо не боится ничего. А почему? Никто не знает... Читали ли Вы воспоминания Над. Як. Манд.? ${ }^{526}$ Что думаете о них? Я считаю их огромным явлением, изумительной книгой. Знают ли о них в Ленинграде? Действительно ли там все идет обратно, и будет де-реабилитация реабилитированных?

Я в июне выхожу в отставку и очень, очень этому рада: подумайте, 20 лет я работала и впереди - свобода, время, буду делать что хочу, буду писать «для себя«, буду читать интересные книжки, собираюсь поехать в Испанию... Вейдле был здесь три месяца, и было очень приятно, а теперь зима, и снег, и много солнца в этом году, и уютно - потому что я до сих пор на каникулах, и весной у меня не будет такой бешеной нагрузки, как была осенью. Если бы не угроза третьей войны, я была бы очень счастлива.

Почему Сартр призывал к гражданской войне? С кем? (Ваше письмо от 27 ноября). ${ }^{527}$

Как Ваше здоровье? Никогда Вы об этом не пишете. Черкните два слова о с самом себе.

Обнимаю Вас.

Нина

524 Berberova is evidently referring to the revolts in the Polish Baltic cities in December 1970 and the constant tension in the Middle East.

525 Šmakov.

526 Nadežda Jakovlevna Mandel'štam.

527 In a program on French television on 21 October 1970 Jean Paul Sartre had directly addressed the workers at the Renault factory and urged them to react to the violence perpetrated by "the repressive state." 
Мой милый друг Гуля,

спасибо за письмо, как всегда интересное (собственно - два письма, сегодня пришло в т о р о е). Можете быть абсолютно спокойны, я ником не читаю Ваших писем и вообще не предаю новостей из них. Только что вернулись ездившие отсюда в Москву молодой профессор и его жена - оба к о р м и л и Над. Як. Манд., ${ }^{528}$ которой живется г о л о д н о. Она очень довольна книгой. Вейдле и я, мы оба думаем, что книга потрясающая, и умная, и талантливая, и изумительно тонко написанная. Я вижу сквозь текст, ч т о именно Н. Як. ч и т а л а - тех же авторов, что и я (европейских и американских).

От Максимова было письмо. Печальное, умное. Я ответила. О чем он Вас просил мне передать в прошлом году? О стихах Карамова? Или о чем-то еще? От Шмакова была открытка. Я тоже ответила. Книга моя (русская) выходит видимо летом. Я сейчас была завалена корректурами. Пишу некий ответ критикам (или критику из Нов. Журн.). Очень это увлекательно, пришлю Вам копию - разошлю ее десяти друзьям с просьбой критических поправок и хочу знать впечатление от моих «возражений«. Знаете ли Вы, что Гуль дважды умолял меня печатать всю книгу в Нов. Журнале? Эти письма его будут процитированы, конечно.

Я не еду этим летом в Европу. Я писала Вам, что Вейдле купили квартиру около Валенсии и я поеду в Испанию весной 72-го года, на два-три месяца, хочу снять дом или квартиру (с двумя спальнями) и жить там, приглашая друзей гостить у меня. Почему Вы не можете приехать в Испанию? Какая политика? СССР торгует с Испанией во всю. И она полна туристов. Впрочем, м.б. Вы не хотите ехать туда из-за религии - это и мне было противно десять лет, но теперь я решила, что это в общем не мое дело. Пусть себе ходят к исповеди. Так и Вейдле смотрит на это. Ленинградская Правда здесь получается, как и многие сов. газеты. А теперь и Ростроповича не пускают заграницу. Дожили! А главное - нечего там читать, нечему студентов учить, и аспирантуру здесь собираются постепенно закрывать в университетах. Нельзя же в самом деле учить сто лет Пушкина и Толстоевского, ${ }^{529}$ хочется и современного тоже! Студентов все меньше, и духовной пищи - никакой. Боюсь, что будет, как в Греции - Софокл и Платон, и

528 Nadežda Jakovlevna Mandel'štam.

529 Tolstoevskij: Nabokov's contamination of the names of the two giants. 
потом - ничегошеньки вплоть до Кавафиса - умер в 1935 г., кажется? А когда попадается рассказ интересный, как напр. Баранской, «Неделя как неделя «, ${ }^{530}$ то это уже и не литература, а социология: узнаешь, сколько стоит аборт и что едят дети утром (картошку и хлеб).

Вейдле мне написал из Парижа, перефразируя Пушкина: «Боже, как мерзка наша Россия «331 после прочтения Над. Як. Манд. Это и я скажу - что мне с Вами стесняться?... Меня страшат события на Ближнем Востоке. Но недавно я нашла в сочинениях Ленина фразу о том, что «арабам нужно помогать«. Это все - одна линия. И говорить, что Ленин - полубог, а Сталин - мерзавец так же глупо, как сказать, что Гитлер - гений, и только Гиммлер и Геббельс - негодяи.

Скажите по совести, есть ли ЧТО-НИБУДь достойное прочтения (после Мемуаров Эренбурга)? Ничего нет. И боюсь, что и не будет.

Милый Гуля, вы неисправимы. Хоть бы Вы когда-нибудь написали мне о себе, о настроении, о здоровье! Вижу, что Вы в глубине души невероятный викторианец, все у Вас покрыто «фраком неизвестности«, и Вы ни словом никогда не откроетесь. Меня беспокоит, не скрываете ли Вы от меня (друга Вашего) какого-нибудь нездоровья? Обнимаю Вас.

Нина

х Нов. Мир ноябрь 1969

530 Natal'ja Baranskaja's (1908-2004) story "Nedelja kak nedelja" describing women's drudgery and juggling of work and family roles had aroused considerable attention when it appeared in Novyj mir 11 (1969). It was soon translated into other languages.

531 See note 495 to Berberova's letter of 21 March 1970. 
13 марта 1971

Милый Гуля, спасибо за письмо. Мы в общем почти всегда с Вами думаем и судим о вещах одинаково: Ваши поправки к моему «Послесловию« были почти все уже сделаны. О мотивах, побуждающих меня звать Бунина и Руднева в Париж - отвечено; эпиграмма приведена (была раньше) в тексте книги и объяснено, почему она была убрана в англ. издании. ${ }^{532}$ Гуль, между прочим, хотел печатать не отрывки моей книги, а целиком - это ясно из его письма, кот. я цитирую.

Корректуры книги только что отослала в Мюнхен. Выйдет вероятно в конце лета.

Фильм «Чайковский«, кот. Вы видели в Ленинграде, сделан по моей книге. ${ }^{533}$ Он в США показан не был - слишком старомоден, растянут и здесь никто на него не пойдет. Литература кончилась, и кино кончается. Даже биографии Ленина, Сталина, Горького и Маяковского написать там не могут - о М-ом только что вышла прекрасная биография поляка в Варшаве, но она не продается в Москве! ${ }^{534}$ И здесь начали закрываться в унив-ах русские отделы - нечему учить студентов. А «Литер. Газету« Вы иногда видите? Там раз в неделю бывает что-то о литературе.

Между прочим, разве я не писала Вам, что «Послесловие« будет напечатано в конце моей (русской) книги? Вы спрашиваете: будет ли оно где-нибудь помещено.

Разослано было около 20 копий ближайшим друзьям. Получила очень много откликов, некоторые - как Ваш - дельные и конструктивно-критические. Спасибо Вам. Шлю привет.

Нина

532 See note 485 to Berberova's letter of 22 November 1969.

533 Thus had Berberova, albeit modestly, begun to cooperate with leading representatives of the Soviet intelligentsia. Innokentij Smoktunovskij and Maja (Majja) Pliseckaja had starring roles in the film that was released in Moscow on 31 August 1970.

534 Wiktor Woroszylski (1927-1996), Życie Majakowskiego, Warszawa 1965. 
18 апреля 1971

Милый Гуля, читали ли Вы замечательную книгу: биография Марселя Пруста, написанная англичанином Джорджем Пэйнтером? ${ }^{535}$ Она переведена на многие языки, французы о ней писали восторженно, как и здешние критики. Это книга - верх совершенства, назабываемая. Конечно, после нее Моруа ${ }^{536}$ кажется пигмеем, и даже Литтон Стрэчи упал в моих глазах. Пэйнтер дает абсолютно идеально связанные жизнь и творчество, или даже можно сказать - творчество, пронизанное жизнью. Это конечно можно было сделать с Прустом, с другими вряд ли это было бы интересно. Гроссман в своей книге о Достоевском один абзац посвящает творчеству, другой - жизни. ${ }^{537}$ Так Пэйнтер, как говорится, - «ничего подобного«. Метод совершенно новый и замечательный. Я в таком упоении, что хочу читать вторично оба тома. Умоляю Вас достать и прочитать эту книгу. Там и о Вашем любимце (де Ренье) сказано, о том, как он дрался на дуэли... Прочтите и напишите мне Ваше мнение.

Фильм, который Вы видели (Чайковский) - сделан по моей книге, но там ничего не осталось от книги, так мне говорят. Здесь его не показали - не было покупателей; такое здесь делали в 40-х г.г. и сейчас от этого ушли. Но я видела английский фильм «The Music Lovers« - Гуля, это н е в е р о я т н ы й фильм. ${ }^{538}$ С одной стороны - ни России, ни П.И. Ч. В нем нет, вообще ничего нет, что напоминало бы реальность. Если забыть, что это что-то, что пытается сказать о реальности, то конечно, фильм не годится никуда. Но как кино-картина, я должна признать, что сила в ней необычайная, и забыть ее нельзя. Она конечно пойдет в Стокгольме. Пожалуйста, посмотрите ее.

Монтерлана я тоже считаю большим писателем (и драматургом). А Сенкевича не помню совершенно. ${ }^{539}$ Читала его когда мне было 12 лет. Гуля, я тоже, как видимо и Вы, читаю очень много. Какое счастье, что у обоих у нас зрение такое хорошее! А вот Бальзака, Диккенса и др. корифеев XIX в. я уже читать не могу.

Привет.

Нина

535 See note 466 to Berberova's letter of 5 September 1969.

536 André Maurois (pseud. of Émile Herzog, 1885-1967), known especially for his biographies of writers.

537 Leonid Grossman (1888-1965), Dostoevskij, Moscow 1962.

538 Experimental film on Čajkovskij (1970) by Ken Russell (1927-2011) that - like Berberova's monograph - strongly emphasized the composer's homosexuality.

539 Henryk Sienkiewicz (1846-1916), Polish winner of the 1916 Nobel Prize in literature. 
Дорогой друг Гуля,

я страшно давно не писала Вам. Стыдно это, но есть объяснение: май месяц был очень у меня трудный - кончался этот очень трудный год. А июнь весь я заканчивала дела, перевозила из университетского кабинета книги, давала последние экзамены, были две шумные последние вечеринки. И наконец - я вышла в отставку. От радости не знаю даже, что мне делать. Подумайте, весь день свободный, и нет больше давящих на меня ч у ж и х проблем! Впрочем, Вы сами в отставке и знаете это роскошное чувство.

Кроме того, в июне пришла верстка из Германии моей (русской) книги. 700 страниц. Надо было читать, надо было делать индекс (алфавитный указатель), которым я занималась до шести часов в день и едва не сошла с ума от такой работы - хотела, чтобы он был без ошибок, не знаю, удалось ли мне это, доверить никому не могла. Словом, неделю тому назад отослала верстку и индекс в Германию, перевезла последние книжки домой, присутствовала на защите последней диссертации (всех за 8 лет было 7), и в одно прекрасное утро почувствовала блаженство неизъяснимое....

Прочту непременно о Рошефор, ${ }^{540}$ и Сабатье, ${ }^{541}$ о кот. Вы пишете. Сама я романов почти не читаю. Сейчас дочитала четвертый том записок Босвелла (всех их одиннадцать) и очень увлекаюсь им. ${ }^{542}$ Затем читала Жака Моно - француз, философ и микробиолог, получивший в 1964 г. Нобелевскую премию. Для меня это было очень важно, я почти всю жизнь именно т а к смотрела на вещи. (“Le Hasard et la Necessité”). ${ }^{543}$ Вы пишете о Тургеневе. Прочтите пожалуйста в новом издании его письма к Виардо. ${ }^{544}$ Он был настоящий ф е т и ш и с т, но об этом в русском переводе писем цензура все вынула. Они ${ }^{\mathrm{x}}$ остались на немецком и франц. языках!!!

540 See note 600 to Berberova's letter of 15 January 1973.

541 Robert Sabatier (1923-2012), French writer known especially for his autobiographical childhood novels.

542 Boswell's London Journal 1762-1763, New Haven, Yale, 1950.

543 Jacques Monod (1910-1976), French geneticist and (together with Jacob and Lwoff) 1965 winner of the Nobel Prize in medicine. His Le Hasard et la Necessité. Essai sur la Philosophie Naturelle de la Biologie Moderne came out in Paris in 1970.

544 See note 580 to Berberova's letter of 15 July 1972. 
Как мне сделать, чтобы Вашему другу, «ленинградскому профессору«, послать мою книгу? ${ }^{545}$ Она выйдет в октябре.

Обнимаю Вас.

Нина

x его нежные высказывания

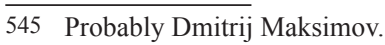


Милый Гуля, это письмо - ответ на два Ваши последние письма, одно разошлось с моим, а другое - от начала августа. Живу я здесь, в Принстоне, этим летом как в раю: читаю книжки, которые несколько лет не могла прочесть, наслаждаюсь каждой минутой спокойствием, свободой и отсутствием ч у ж и х проблем. Своих давно нет. Погода чудная, жаркая, как я люблю, всё в цвету; люди разъехались, многие в Сов. Союз. Иногда беру автомобиль свой и еду к друзьям погостить, то в чудные холмы Пеннсильвании, то на берег океана. Ложусь рано, встаю рано, настроение хорошее, здоровье, как говорится, завидное, а главное - могу читать с раннего утра до позднего вечера. Главным образом - НЕ романы и не многоуважаемое «старье«, а очень важные (для меня) книги современности.

Прочитала Жака Моно «Ле азар э ля несесите« (ответ на все сомнения человечества), три тома биографии Бертрана Рассела (даже такой мозг, как его, сдал в 80 лет!), Тацита, переписку Стрэчи и Вирджинии Вуль $\phi,{ }^{546}$ неск. книг о Д. Х. Лоренсе (кот. раньше не читала), и даже Даниэля Дефоэ «Дневник« лондонской чумы. ${ }^{547}$ «Старье« - это для меня XIX век, к «старью« не относятся «древние«. Сейчас лежит передо мной Светоний ${ }^{548}$ и Марк Аврелий. ${ }^{549}$ Хочу заглянуть и в Тита Ливия, кот. к своему стыду никогда не читала. ${ }^{550}$ Но был и один роман, кот. я хотела бы, чтобы Вы прочли: Сол Беллоу «Планета Мистера Саммлера« - он переведен на все языки, кажется, потому что Беллоу считается одним из самых знаменитых американских писателей. Не то чтобы роман был уж так хорош (последняя треть НЕ хороша совсем, две первые трети превосходны), но в нем есть интересное для нас с Вами - герой романа «последний европеец«, и фигура довольно трагическая. Два года тому назад Беллоу получил все возможные премии, и книга была здесь и во Франции бестселлером. ${ }^{551}$

Как интересно было мне прочесть про Вашу молодую знакомую, пишущую о Кузмине! Мой бывший студент, а теперь профессор -

546 Virginia Woolf/Lytton Strachey, Letters, London 1956.

547 Daniel Defoe, A Journal of the Plague Year, London 1966.

548 Suetonius (69-after $122 \mathrm{AD}$ ), writer, known not least for his unflattered portraits of contemporary Roman emperors.

549 Marcus Aurelius (121-180 AD), Roman emperor, Stoic philosopher, author of famous Meditations.

550 Titus Livius (59 BC-17 AD), most prominent prose writer of the Augustan period, friend of Caesar Augustus, author of (unfortunately incompletely preserved) Roman history from its beginnings.

551 Saul Bellow, Mr. Sammler's Planet, New York 1970. 
редактор нового собрания Кузмина, которое выпускает Финк Ферлаг в Мюнхене. ${ }^{552}$ Он сейчас работает над биографией Кузмина, собрание выйдет в пяти томах. ${ }^{553}$ Влад. Марков его «соредактор ${ }^{554}$ Непременно напишите мне, кто эта дама, чтобы Джон мог познакомиться с ней в Париже, где он скоро собирается быть. Между прочим, у него в Париже есть несколько русско-армянских знакомых, может быть он ее уже знает, а она его?

«Август 14-го« еще не читала и даже книги не видела. ${ }^{55}$ Боюсь, не смогу одолеть «батальные сцены« и буду сидеть над книгой, как та девочка, кот. читала «мир« и пропускала «войну« в другом батальном романе. А еще была девочка, уже не из анекдота, а кот. я видела сама (сестра Аллы Головиной, ${ }^{556}$ была такая поэтесса), кот. горько плакала над «Анной Карениной«, и когда я ее спросила, над каким местом она плачет, она сказала, что плачет от СКУКИ, - этого я никогда не забыла! «Курсив« по-русски я конечно Вам пришлю. В этом не может быть никакого сомнения. Но это будет м. б. в ноябре (издатель пишет - в октябре). Я думаю, что книга выйдет к рождеству.

Выставка Пруста в 65 г. была невыносимо плоха и я была ужасно ею разочарована. Сейчас, конечно, жалею, что не могу в Париже пойти на ту, кот. открылась. Но после книги Пэйнтера (я Вам кажется писала о его превосходной биографии Пруста?) мне кажется я немножко объелась Прустом. ${ }^{577}$ Это чувство скорее приятное. Для меня Пруст - величайший в нашем столетии (о чем есть в моей автобиографии).

Между прочим, в книге моей будут и два русских «непечатных« слова, кот. есть в английском издании, и кот. говорит Бунин. Я даже спросила Вейдле, когда он был в Принстоне, не будет ли он шокирован этим (в русской печати - впервые, и конечно в с е остальные русские писатели шокированы будут). Вейдле сказал: «Конечно нет. Что же Вам, точки что-ли ставить?? И ведь не Вы их произносите, а Бунин!« И я успокоилась.

Вот пока и все. Обнимаю Вас. Пишите.

Нина

552 John Malmstad. See note 421 to Berberova's letter of 16 February 1967.

553 Michail Kuzmin, Sobranie stichov 1-3, Munich 1977.

554 Vladimir Markov (1920-2013), professor at UCLA, expert on Russian Futurism.

555 Aleksandr Solženicyn, Avgust 14-go, Paris 1971.

556 Alla Golovina (1909-1987), émigré poet, influenced by Cvetaeva.

557 See note 466 to Berberova's letter of 5 September 1969. 
Принстон, 20 ноября 1971

Милый Гуля, как Вы поживаете? что делаете? с кем дружите? Я очень ценю Ваши письма о книгах и их авторах, но годами ничего не писать о самом себе в конце концов сушит переписку. Я как-то перестала видеть Вас, понимать, представлять себе Вашу жизнь. Никогда ни слова ни о чем. Странный Вы корреспондент!

Боюсь, что мое путешествие в Испанию не состоится: сначала был слух, что там холера. Потом - более подробные сведения об эпидемии. Я запросила Вейдле. Он написал, что - увы! - ему пришлось привить холеру. Я ничего, конечно, прививать себе не собираюсь, от прививок у меня немедленно делается именно эта болезнь, и жизнь в стране, где нельзя есть фруктов и свежей зелени (я все меньше ем мяса) меня не соблазняет. Мои молодые друзья тянут меня в Вену и Югославию в мае. Может быть полечу с ними, еще не решила, во всяком случае в Париж меня совершенно не тянет, и если я и буду во Франции, то вероятно только в Провансе. Все это приятно обдумывать, но приятно и здесь сидеть - Принстон просто прелестен осенью, в багрец и золото одетые леса очень красивы, а друзья все тут, или в 2-3 часах езды на автомобиле. Часто выезжаю к ним (на север и на юг).

19 век для меня изношен, как башмак - я против него ничего не имею. Вы меня не совсем поняли. Верди и Шелли, Пушкин и пред-импрессионисты - знакомы, как старые родственники. Люблю, но больше не реагирую на них. Прошла недавно в своем чтении через поздних викторианцев Англии (после Рескина ${ }^{558}$ и Карлейля, ${ }^{559}$ и до Блумсбери $\left.{ }^{560}\right)$. Какие это были больные и слабые люди! Тита Ливия, конечно, я не читаю все семь томов, но полтора прочла. Боже, как хорош Светоний!! А над Саллюстием я скучаю. ${ }^{561}$ Деление Вейдле искусства на «и-во вымысла« и «и-во слова« для 20 века совсем не годится. И вообще - большая натяжка.

Милый Гуля, если увидите Максимова, кланяйтесь ему. Моя студентка у него сейчас работает. Для нее он - ископаемое, но она ценит его очень.

Привет.

Нина

558 John Ruskin (1819-1900), English art critic and poet, one of the Pre-Raphaelites.

559 Thomas Carlyle (1795-1881), Scottish historian of the French Revolution.

560 The politically radical Bloomsbury group.

561 Sallustius (86-35 BC), Roman historian, noted for laconic style, supported by Julius Caesar. 
Принстон, 23 января 1972

Милый Гуля,

Вы браните меня, что я так долго молчала. В свое оправдание скажу, что после моего письма в конце ноября я получила от Вас письмо, в кот. Вы написали, что «во второй половине декабря« едете к Тане. (На сколько времени - неизвестно.) Так что куда же было мне писать? Впрочем, я стала лениться, все больше читаю интересные книги, и равнодушно смотрю на пишмашинки (англ. и русск.), которые потеряли для меня некоторую прелесть. Видели ли Вы Лид. Як. Гинзбург в Ленинграде? Я получила от нее ее замечательную книгу «О психологической прозе « ${ }^{562}$ Видно, что она «а ля паж« и такая современная, каких вероятно очень мало в СССР. И ей нравится мой «КУРСИВ« (кот. она прочла по-англ.), что мне очень приятно. Здесь был главный директор Финк-Ферлаг, Зивекинг. Сидел у меня два дня. Думал, я буду ругать его за опоздание с книгой, но я знаю, что она печатается в Югославии, а там социализм и планирование, так что работают без энтузиазма, к сожалению, и тянут. ${ }^{563}$

Только что кончила книгу Сартра о Флобере (только юность, и 1100 стр. мелким шрифтом). ${ }^{564}$ Французы в $60-$ х годах открыли Фрейда (Башелар ${ }^{565}$, Сартр, Пулэ ${ }^{566}$, Ришар и др.) и теперь многословно его комментируют. Но я советую Вам этот «эвр« прочитать - многое в нем ново и сногсшибательно.

Моя поездка в Европу принимает некоторые формы, пока еще туманные, но тем не менее я хочу Вам о них сказать: я хочу вылететь отсюда в первой половине апреля, провести 2 недели в Мадриде и в 8-и местах (смотреть во все глаза), затем май прожить под Валенсией, у моря (не одна), и потом полететь в Вену, и июнь промотаться между Австрией, Швейцарией и Италией. Как Вам это покажется? На каком перекрестке можно было бы встретиться? В Тироле? В Венеции? Подумайте о своих планах. Хотелось бы мне быть дома до 1 июля, когда толпы туристов заполняют Европу.

Обнимаю Вас, с Новым Годом!

562 Lidija Ginzburg, O psichologičeskij proze, Leningrad 1971.

563 Vincent Sieveking (b. 1938), Slavist, publisher.

564 See note 568 to Berberova's letter of 7 March 1972.

565 Gaston Bachelard (1884-1962), French philosopher.

566 Charles Poulet (1887-1950), French Benedictine monk and church historian. 
Письма Чичерина и Кузмина я знаю. ${ }^{567}$ В моем сейфе в банке лежат вещи, кот. провели бы Вас в восторг.

Нина

Спасибо за открытку из Ленинграда - вместе с М. Судаковой!

567 The early correspondence between Kuzmin and the Bolshevik regime's first foreign minister was published by S. Tschimichkian, "Extraits de la correspondance Mihail Kuzmin-Georgij Čičerin,” Cahiers du Monde Russe et Soviétique 1-2 (1974). 
Принстон, 7 марта 1972

Дорогой Гуля,

Ваше письмо получила. Вы пишете мне о книгах, и я напишу Вам о книгах. Читаю по 4-5 в неделю, это теперь главное мое дело, нагоняю прошлое. Видели ли Вы Сартра ДВА ТОМА о Флобере - и только ДО 1857 г. (т.е. до М. Б.)? Каждый том - 1100 страниц. Я не шучу. Галиматья марксистская и фрейдистская - до Сартра Фрейд наконец дошел! Я прочитала и узнала довольно интересные ФАКТЫ: сексуального порядка. А больше ничего. ${ }^{568}$

Читала Медведева о деле Лысенко. Плохо написано, и Медведев - увы - не писатель. ${ }^{569}$ Нет «общей« культуры. Но кое-что из этой книги я вынесла - касательно биологических и и социальных законов наших. Недавно вышла работа некоего Роберта Вильямса «Кулчур ин экзайл«, о русской эмиграции в Германии 1881-1941. Мне было интересно, но уж очень много внимания уделено там монархическим спорам 20ых годов - перевешивают остальное. Хотя к «кулчур« (или «калчур«) они отношения не имеют. (Меня цитирует.) $)^{570}$

10 апреля лечу в Испанию, сняла там квартиру. Кое-кто из друзей здесь в мае приедет туда, ко мне в гости. Я Вам оттуда напишу. Планы мои на июнь туманны. Может быть останусь там дольше, чем сейчас планирую. Слышала, что Над. Як. Манд. умирает. Только что кончила В ВЕРСТКЕ читать ее ВТОРОЙ том Воспоминаний - довольно злой. ${ }^{571}$

То, что Вы пишете об уничтожении книги Газданова изд. ИМКА, за неприличие, случилось и с «Облегчением участи« - ее не уничтожили, но заперли в подвал. Судакову я вообще совсем не знаю (ответ на Ваш вопрос) - она слушала мои лекции. Ее энтузиазм объясняется тем, что ей они нравились. Отложив скромность могу сказать, что окромя энтузиазма я ничего другого от своих слушателей и не жду. Мне деньги университет платил хорошие именно за то, что был энтузиазм. Я их даром не брала! И близкие мне люди здесь - ВСЕ мои бывшие слушатели.

Обнимаю Вас, Гуля.

Нина

568 Jean Paul Sartre, L'idiot de la famille: Gustave Flaubert de 1821 à 1957 1-3, Paris 1971-1972.

569 Žores Medvedev (1925-2018), The Rise and Fall of T.D. Lysenko, New York 1969.

570 Robert Williams, Culture in Exile. Russian Emigrés in Germany, 1881-1941, Ithaca, N.Y., 1972.

571 Nadežda Mandel’štam, Vtoraja kniga, Paris 1972. 
Принстон, 17 июня 1972

Милый Гуля, вернулась из Испании и нашла здесь два Ваших письма: от 8, другое от 17 апреля. Итак, мы не увиделись в этом году. В Испании было удивительно интересно: советские футболисты играли в Валенсии, а в Мадриде теперь есть представительство (полу-официальное). Всё мне было интересно - и климат, от которого все болезни, какие у кого есть, проходят, и люди (ужасно некрасивые, особенно женщины), и Веласкез, и Гойя, и города Андалузии, и пейсаж вокруг Аликанте, и еда (очень мне подходящая), и рабочая политика Франко, и будущее страны ввиду фигуры Жан-Карла.... ${ }^{572}$ Словом, я «образовалась« там в своем незнании и некоторых предрассудках - особенно касательно католической религии, которая тихо уходит в небытие. Аборты ее доконали.

Напишите, как Вам понравился КУРСИВ, не притворяйтесь, если не очень понравилось. Многие пишут мне, что это «совсем другая книга«, чем ее американо-английское издание. Посоветуйте, что мне делать с советскими, которые умоляют послать им экземпляры? Мучаюсь, не знаю, что делать: по воздуху посылать - больше 10 (!) долларов за экземпляр платить, без гарантии, что дойдет, а не по воздуху - так уж наверное не пропустят. А карманов таких нет, чтобы ее прихватить собой туристу! Кстати, не знаете ли Вы, когда еще выходила книга в 700 стр. В эмиграции? Меня несколько человек спрашивали, и я не знала, что ответить. Послать в Сов. Союз необходимо: Макашину ${ }^{573}$ в Лит.Наследство, Максимову, Орлову, Григорьянцу, ${ }^{574}$ Шмакову. И так хотелось бы тоже Миндлину, ${ }^{575}$ Иде Наппельбаум и кое-кому еще. А уж про Лид. Як. Гинзбург и не говорю: это для нее страшно важно, потому что написала именно она э т и т е м ы в своей последней книге (О психологическом романе) - т.е. о мемуарах, стоящих посередине между «фантазией« (так наз. «художественной лит-рой«), и документальным материалом. (А Гуль, бедный, видно сошел с ума: видели ли Вы, что он написал о церкви в эмиграции в № 106?). ${ }^{576}$

572 "Jean-Carl" = Prince Juan Carlos (b. 1938), the future King of Spain (1975-2014).

573 Sergej Makašin (1906-1989), editor of the literary documentation series Literaturnoe Nasledstvo.

574 Sergej Grigor'janc (b. 1941), literary scholar, active in the civil rights movement.

575 Ėmilij Mindlin (1900-1981), writer and journalist interested in Scandinavia to whom Marina Cvetaeva's poem "Otrok" (1921) is dedicated.

576 Roman Gul', “K voprosu ob 'avtokefalii,"” Novyj Žurnal 106 (1972). 
Жду от Вас письма-рецензии. Не стесняйтесь со мной. От друга я приму с радостью критику, и Вы это знаете.

Нина 
Принстон, 15 июля 1972

Дорогой Гуля, через неделю я уезжаю до 15 сентября - сначала гостить на север, а потом - на один маленький остров на океане, близко от Бостона. Путешествие на автомобиле, конечно, и я предвкушаю о ч е н ь и самую поездку, и встречи со старыми друзьями, у которых буду гостить. Приехала из Испании и целый месяц «нагоняла« - писала письма, читала журналы, приводила в порядок бумаги и т.д. Приехала после 10 месяцев в Ленинграде моя «аспирантка« - умница, душка большая, которая в Л. главным образом якшалась с поэтами вокруг Бродского, которому она предложила жениться на ней, чтобы она его могла вывезти заграницу. Их имена вывесили во Дворце Свадеб (!), но накануне венчания Б. получил выездную визу и затем выехал. ${ }^{577}$ Сейчас он в Мичигане. Аспирантка приехала ко мне, жила у меня и говорила без остановки по 10 часов в день - она чудно говорит по-русски. Привезла мне письма от тех, кто не пишет через почту. Это было страшно интересно и во многом трогательно. Меня там ждут (в известных кругах, конечно), а еще больше, по-моему, ждут КУРСИВ. Знаете ли Вы Берковского? Встречали ли его? Увидите ли Г. Ш., ${ }^{578}$ когда опять поедете? Всех этих людей она знает и очень любит.

С Вашим первым возражением я согласна: может быть я слишком строга к эпохе 1907-1913 в России. Но Александр II, увы, теперь, после опубликования документов его эпохи - не мой герой. И его «реформы«, о кот. Вы упоминаете - мыльный пузырь, что выяснилось к концу столетия, когда мужики остались без земли. Насчет Белого движения это у Вас какие-то «девичьи грезы« - я была при Деникине в Ростове и у нас в доме жило офицерье. Даже мой отец призывал приход Буденного, такие это были свиньи. Отец, конечно, ошибался, и Буденный для н а с был еще хуже. А слова «патент на благородство« я постараюсь считать Вами не произнесенными. Мне от них за Вас стыдно.

Простите, что пишу откровенно, но если не писать откровенно, то зачем вообще писать? Третье - «брюсовские декорации« остались в $\mathrm{BX}^{579}$ от его молодости, когда он в публике появлялся с бриллиантовой брошкой и считал Северянина большим поэтом (было и это). «Брюсовские декорации« Вам не видны, они $\underline{\mathrm{HE}}$ В СТИХАХ, а в его поведении,

577 Iosif Brodskij was forced to emigrate on 4 June 1972.

578 Gennadij Šmakov.

579 Chodasevič. 
манерах, и в общении с людьми. ${ }^{\mathrm{x}}$ И они не могли исчезнуть в 20 и 30 г.г., когда его не было и 50-ти лет (ему было 53 года когда он умер).

Прилагаю два экземпляра «опечаток«. Пожалуйста, исправьте Ваш экземпляр книги. А второй листочек м.б. пригодится, если Вы встретите мою книгу в Стокгольмской (университетской) библиотеке.

Спасибо за Вашу критику.

Мне нравится мысль встретиться с Вами в Баден-Бадене. Я с удовольствием приеду туда (в 1973 г.), когда Вы там будете. И мы будем говорить о Тургеневе. Читали ли Вы его письма к Виардо в новом издании писем (кажется 12 томов). Там «непристойности« (в советском понимании) НЕ ПЕРЕВЕДЕНЫ ПО-РУССКИ!! Он, конечно, быЛ сексуальный маниак (насчет лепестка розы - он просит ее положить его между пяткой и каблуком, носить целый день, а потом послать ему). А мы в детстве интересовались: жил он с ней или не жил? Разве в ЭТОМ было дело ${ }^{580}$

Обнимаю Вас.

Нина

${ }^{\mathrm{x}}$ И даже в его Weltanschauung

580 Ivan Turgenev, Polnoe sobranie sočinenij v dvadcati vos'mi tomach, Moscow 1960-1968. Thirteen entire volumes consist of letters. 
Принстон, 1 октября 1972

Дорогой Гуля, где Вы? Здоровы ли? В порядке ли - во всех смыслах? Я вернулась с океана в середине сентября и не нашла от Вас ни строчки. Меня беспокоит, что с июня от Вас не было письма, несмотря на мои открытки и письмо (от 15 июля). Знаете ли Вы, что Берковский умер? Еще летом! И совсем был не старый. Он перед смертью получил мою автобиографию по-английски и ее прочел.... Максимов прислал мне 2ой Блоковский сборник с превосходной его статьей о Блоке. ${ }^{581}$ Там тоже есть материалы о Кузмине. ${ }^{582}$ Страшно все интересно. На этой неделе ко мне сюда приедет Бродский, который прочел КУРСИВ и очень его любит. Жду Бродского, хочу послушать хорошие русские стихи, которых никто кроме него не пишет.

Гуля, я пишу, и все думаю, благополучны ли Вы? Не больны ли? Ответьте сейчас же, чтобы мне знать. Ваше молчание никогда не было таким длинным. Может быть Вы обиделись на меня за то, что я написала о Белом движении? Но это было бы совсем не в Вашем духе! Когда будете в Ленинграде? Как Таня? Увидимся ли мы с Вами когда-нибудь в Баден-Бадене? Что Вы думаете об «Августе 1914«? Я думаю, что это лучшая книга Солж., у меня дух захватывало на каждой странице. И самая «современная« из всех его книг.

Жду Вашего письма. Успокойте меня.

Нина

581 Dmitrij Maksimov, "Ideja puti v poètičeskom soznanii Al. Bloka," Blokovskij sbornik 2, Tartu 1972.

582 Gennadij Šmakov, "Blok i Kuzmin (Novye materialy)," ibid. 
Принстон, 30 октября 1972

Милый Гуля,

спасибо за письмо. Наконец-то я узнала, что Вы живы и здоровы. Сама я тоже жива, и здорова, чувствую себя хорошо, даже очень хорошо, лето было мне на пользу. (Я теперь почти вовсе не ем мяса.) И в общем потребовался целый год для того, чтобы мне придти в себя от 25-тилетней усталости (или 50-тилетней?) и стать нормальным, свободным и веселым человеком.

Читаю ужасно много, и с громадным удовольствием. Но в противоположность Вам - только современников. А по-русски совершенно нечего читать: Бродский был у меня целый день, и советовал читать Платонова. Но эта скучища не для меня! Бродский читал чудные новые стихи, талантливый, милый, очень умный, грустный, нервный, уже немножко избалованный. Но это последнее - ничего. Впереди у него еще Бог знает чего предстоит, так уж пусть попользуется сейчас своей славой и успехами. Мы подружились. А вот Берковский умер. Это меня ужасно огорчило. Перед смертью он успел прочитать мою книгу по-английски.

Читали ли Вы замечательный роман Мишеля Турнье Le Roi des Aulnes (Гонкур 1971)? Я прямо с ума схожу от восторга, собираюсь читать во второй раз. За 25 лет я ничего французского не находила, чтобы так наслаждаться. ${ }^{53}$ Гуля, читали ли Вы биографию Жида (молодого)? ${ }^{584}$ И прочли ли Жизнь Флобера (Сартра)? ${ }^{585}$ Черкните, что думаете об этих книгах.

С Ленинградом у меня постоянная связь (у Иды Напп. был обыск), но дела там идут все хуже и хуже. Кто не в тюрьме, тот в сумасшедшем доме, а кто не в доме, тот спивается, а кто не спивается, тот вешается. Кое-кто из балетных мальчиков, впрочем, ускользнул в Вену. Обнимаю Вас. Жду письма.

Нина

«При свидании« мы не будем вовсе «спорить о Белой армии«! Иначе не будет свидания!

А Баден-Баден и Интерлакен очень соблазнят меня!

583 Michel Tournier (1924-2016), Le Roi des Aulnes, Paris 1970.

584 See note 586 to Berberova's letter of 17 November 1972.

585 See note 568 to Berberova's letter of 7 March 1972. 
Дорогой друг Гуля,

спасибо за письмо. Всегда радуюсь Вашим письмам. На этот раз сомнение вкралось мне в душу: я боюсь, что мы стали не всегда понимать друг друга. Судите сами: я Вам пишу про невероятно интересную биографию молодого Жида, а Вы пишете, что читали давно его автобиографию. Автор огромной книги - Жан Делэ (Delay), и она не имеет никакого отношения к книге Жида. ${ }^{586}$ Второе: я прошу у Вас совета, что читать из советской прозы. Вы советуете Окуджаву «Глоток свободы,${ }^{587}$ который на десятой странице раскрыл все свои карты, все уже понятно, известно, невероятно скучно, пресно, и написано для детей 12-летнего возраста. Увы, я совершенно больше не могу читать детских книг. В биографии Флобера (Сартра) по-моему «заглянуть следует« (2250 страниц!) - Сартр от этого Вам милее не станет, а будет еще противнее, может быть. Но все-таки о Флобере Вы узнаете ОЧЕНЬ много (а его мать была подстать матери Жида, и результаты были более или менее те-же самые). Немцы превосходны: Йонсон, ${ }^{588}$ Бёлль, ${ }^{589}$ Грасс и др. Мне все интересно у них. Читала я недавно Черчиля, воспоминания о ПЕРВОЙ войне (русский фронт), чтобы увидеть воочию как много Солженицын взял у него для «Августа«. И хорошо сделал!

О недоразумениях наших свидетельствует еще то, что Вы меня упрекаете в том, что я предъявила Вам УЛЬТИМАТУМ в связи с Белым движением. Никогда я этого не делала! Я только написала, что в Баден-Бадене мы говорить о Б. дв. ${ }^{590}$ не будем - какой же это ультиматум? Я, по правде говоря, даже не помню - когда и кому в жизни я предъявляла ультиматумы? Совсем на меня не похоже.

Я читаю много, ничего сейчас не пишу, но работаю по истории русского масонства 1908-1950. ${ }^{591}$ Не тороплюсь с этим. Прочитала недавно последний роман Набокова (английский) - по-русски название можно, пожалуй, перевести «Прозрачные вещицы.${ }^{592}$ Очень слабо, к сожалению; как-то даже стыдно за него. Привет Вам. Максимову и Шмакову

586 Jean Delay (1907-1987), La jeunesse d'André Gide 1-2, Paris 1956-1963.

587 Bulat Okudžava's novel about the Decembrist Pavel Pestel' (Moscow 1971).

588 Uwe Johnson (1934-1984), German novelist.

589 Heinrich Böll, German Nobel prize winner of literature in 1972.

590 Beloe dviženie.

591 In 1986 Berberova published Ljudi i loži. Russkie masony XX veka (New York).

592 Vladimir Nabokov, Transparent things, New York 1972. 
я месяц тому назад отправила письма. Спросите их, получили ли они их. Расскажите Максимову о Курсиве.

Нина 
(Undated, 1973)

Дорогой Гуля, сейчас получила Ваше письмо после приезда из Ленинграда. Я потрясена новостями, о кот. Вы пишете с невероятной и непонятной небрежностью, и кот. для меня столько значат!! Умоляю Вас понять, что Ваше каждое слово о моих б л и з к и х (Ляля Зейлигер) для меня полны абсолютного интереса и громадной важности. Вот уже 15 лет как Вы ездите в Л., и только сейчас Вы написали мне не только, что она жива, что она в Л., но что она мне шлет привет!!! Я потрясена. Знает ли она, что о ней есть в Курсиве? (Там есть и об Эсе, ${ }^{593}$ но мало и без фамилии, а про Лялю много и про всю ее семью!! $\left.{ }^{594}\right)$. Гуля, я прошу Вас помнить, что в след. раз когда Вы поедете, Вы должны ей рассказать своими словами все, что есть о ней, о ее отце, матери, брате, сестре.... (Стр. 57-61). Заметьте это себе где-нибудь. С Эсей у меня не было близкой дружбы, Нату Давидович я знала слегка, но Ляля и Наташа Шкловская ${ }^{595}$ были самыми мне близкими и дорогими, и я никогда не забывала их.

Я в переписке с Терцем. ${ }^{596}$ А Вы? У меня сейчас в Москве-Ленинграде приятель, вхож во все литературные места, 28-го возвращается. Я с ним послала подарки знаменитым «дамам«, подругам давно умерших поэтов. Они мне тоже посылают с ним подарки. Да, я хотела бы увидеть многих, но сейчас ввиду происходящего на Бл. Востоке я не поеду ни в одну про-арабскую страну, и бойкотирую французские продукты. Мои чувства в этом деле очень сильны и стойки. Когда все уляжется, тогда посмотрим.

Мне живется хорошо. Начала читать (22 тома) Литературный Дневник Гонкуров. Вы вероятно знаете, что в 1956 году он впервые был выпущен с комментариями и БЕЗ КУПЮР. Я, признаться, ничего подобного не ожидала: о литературе там мало, но о публичных домах, полу-девах, девках, бабах, женщинах и дамах - весьма много. Грязь, мерзость и вонь Парижа невероятная! Ренан, ${ }^{597}$ и Тэн, и Флобер (конечно), и Готье, ${ }^{598}$ встречаясь на лит. обедах, спрашивают друг друга: с кем, сколько раз и в какой позиции? И это, видимо, так будет продолжаться

593 Ėsfir' Kolodina.

594 Elena (Ljalja) Zejliger. See Kursiv moj, Moscow 1996, 76.

595 Ibid., 88-92, 707.

596 Andrej Sinjavskij's pseudonym.

597 Ernest Renan (1823-1892), French philosopher, famous for his book La Vie de Jésus (1863).

598 Théophile Gautier (1811-1872), French Parnassist poet, dramatist, novelist and critic. 
все 22 тома. Для меня есть и забавное, только нет ничего такого, что я ожидала: дневник принадлежит не истории литературы, а этнографии, и посколько отражает «быт« и «нравы« - читать его не скучно. (Только иногда - противно). ${ }^{599}$

Обнимаю Вас. Напишите мне о себе и здоровье.

Нина

599 Edmond et Jules de Goncourt (1822-1896, 1830-1870), Journal: mémoires de la vie littéraire 1-2, Paris 1956. 
Принстон, 15 января 1973

Милый Гуля, я просила Вас в моем письме узнать у Максимова и Шмакова, получили ли они мои письма, посланные в октябре (мое письмо Вам от 17 ноября). Вы ничего мне об этом не написали. Я не ответила на Ваши два письма потому, что Вы сами написали мне, что едете в Л. и что Вас в Стокгольме не будет. Бродскому я не могла дать знать - он укатил в Венецию, хотя я ему и говорила, что лучше было бы подождать до весны. Он ждать не мог. Стрелой - туда, в первый же день рождественских каникул!

«Le répos du Guerrier«, который Вы так любите, мне показался (три года тому назад) романом комическим: я громко смеялась на каждой странице. Может быть это так и надо? Или он написан всерьез? Мужчина, здоровый, молодой, годный к работе и т. д. - сидит целый день на постели голый, готовый на все? Мне и сейчас это смешно. Это никак я принять не могу. Как юмористический роман - задумано не плохо. ${ }^{600}$

Продолжаю читать мемуары прежних лет, скоро закончу этот «цикл«, который наводит на меня иногда ужас, иногда тоску. Читали ли Вы в свое время три тома Маргулиеса (которого я знала лично в Париже в 1924-25 г.г., и кот. Вы вероятно встречали в Гельсингфорсе в 1919 году)? Вот ответ на Белое движение и Деникинскую и Врангелевскую эпоху! ${ }^{601}$ Знали ли Вы сына М-са, Юру? Он недавно умер, проработав в Объединненых Нациях больше 20-ти лет. Был «китаевед«. Знакомы ли Вы с работами Леви-Штрауса (или по-французски - Стросса)? Я с огромным интересом читаю его антропологические труды (лингвистические мне не по зубам). ${ }^{602}$ Вообще все больше могу жить без «беллетристики«.

Читали ли Вы когда-нибудь литературного критика, крупнейшего в США, Эдмунда Вильсона? Он недавно умер. Он знал русский, писал о Пушкине, Тургеневе, Толстом. Был законченным европейцем, и очень в свое время помог Набокову (в 40-х г.г.). Сейчас вышла его последняя книга (Окно в Россию). ${ }^{603}$ Там он цитирует мой Курсив очень я была тронута.

600 Christiane Rochefort's (1917-1998) novel Le Répos du Guérrier (1958) was filmed in 1962 by Roger Vadim.

601 Manuil (Ėmmanuil) Margulies (1869-1939), physician, lawyer, politician, author of God intervencii 1-3, Berlin 1923.

602 Claude Lévi-Strauss (1908-2009), French anthropologist and ethnologist.

603 Edmund Wilson (1895-1972), A Window on Russia, New York 1972. 
Был у меня издатель мой из Мюнхена, провел два дня. Говорит, что книга идет - но на русских читателей они НИКОГДА не рассчитывают. Обнимаю Вас. Не болейте! Это еще что такое?

Нина

Пост Скриптум. Грустное впечатление произвело на меня книга А. Туркова о Блоке (читали ли Вы ее?). ${ }^{64}$ Он пересказывает своими словами BCE: от «Прекрасной Дамы« до «Балаганчика«. Вдруг неожиданно (на 161 стр.) пускается в рассуждения о «звуках«: «Над чорным городом как стон«.... Открыв эту Америку, мгновенно о ней забывает. Чтобы подпереть что-то в жизни Блока в 1907 г. цитирует его письмо к Люб. Дмитр. 1903 года. А затем пишет о ней так:

«Л.Д. провела лето в театре. Вернулась осенью. Зимой у нее родился ребенок.«

Это все - опять для детей 12-тилетнего возраста (или даже 8-милетнего). Кстати, о воспоминаниях Л.Д. Блок, о кот. Вам говорил Савинов: ${ }^{605}$ они лежат в моем письменном столе. Мой друг снял с них копию в Л-де 6 лет тому назад и дал ее мне на сохранение. Они ЧРЕЗВЫЧАЙНО интересны. ${ }^{606}$

604 Andrej Turkov (1924-2016), Aleksandr Blok, Moscow 1969.

605 Aleksej Savinov (1906-1976), art historian in Leningrad.

606 They were not published until 1979: Ljubov' Blok: I byl', i nebylicy o Bloke i o sebe (Bremen). 
Принстон, 15 марта 1973

Милый Гуля, Ваше письмо от конца января я давно получила. Здоровы ли ВЫ? Как настроение? Какие планы? Я теперь «пожинаю плоды« своих трудов: у меня кажется скоро будет больше «поклонников« в Сов. Союзе, чем здесь. После чтения моего КУРСИВА получила несколько драгоценных для меня писем (и приглашений). А одно так и совсем потрясающее - не могу написать от кого, но не от «внутреннего эмигранта«, а от человека близкого к «пирогу«.

Я Вам писала, что «Отдых воина« считаю романом комическим. ${ }^{607}$ А Вы мне возражаете, что он «правдоподобен« и упрекаете, что я называю его неправдоподобным. Я никогда не писала Вам такого! И слово «правдоподобие« и «неправдоподобие« я уже лет 45 как не употребляла. За последние 2-3 года, как я уже несколько раз писала Вам, между нами происходят какие-то мелкие недоразумения, как будто Вы не всегда меня понимаете. Вероятно, виновата я, пишу темно. А мож. быть виноваты Вы - не кладете моего письма перед собой, когда отвечаете мне - а я всегда это делаю.

Читаю много, пять-шесть книг в неделю, но главным образом книги нашего времени. И мало романов. После Турнье мне все кажется не слишком интересным. Читали лы Вы Оливье Тодд (француз) «L'année du Crab«. Так себе, не плохо, но и не хорошо. ${ }^{608}$

Берковский, о кот. Гена ${ }^{609}$ и другие так грустят, автор книги о Чехове. Книга замечательная. После нее студентам ничего не нужно больше знать о Чехове. Это был (Берковский) прелестный человек. Как странно, что Вы его не встречали в Петербурге! Книга Эдмонда Вильсона о русской литературе (в кот. он цитирует меня) - мало интересна. Он писал ее когда уже сильно поддался умственно и в ней много милых глупостей и старческих дуростей, кот. видимо сильно раздражали в свое время Набокова. ${ }^{610}$

Привет самый сердечный.

607 See note 600 to Berberova's letter of 15 January 1973.

608 Olivier Todd (b. 1929), L'année du Crab, Paris 1973.

609 Gennadij Šmakov.

610 See note 603 to Berberova's letter of 15 January 1973. 
Принстон, 25 сент. 1973

Милый Сергей Александрович,

если Вы не можете называть меня Ниной или Ниночкой, то еще меньше оснований у меня называть Вас Гулей. Спасибо за письмо, или даже - два. Очень было интересно прочитать про Ленинград. Не могли бы Вы спросить Эсю Колодину, жива ли Наташа Шкловская? Не могли бы Вы повидать Иду Наппельбаум, живущую на ул. Рубинштейна? И передать ей те страницы «Курсива«, где есть про нее ${ }^{611}$ Я рада, что Вы повидали Орлова. Что касается меня, то я полечу в Париж в ноябре если Д.Е.М. ${ }^{612}$ приедет читать лекции в Сорбонну, я должна ему передать кое-какие материалы из моего архива. Боюсь однако, что сов. власть не даст ему визы. У меня переписка (и даже обмен подарками) с ЛЮБ. ${ }^{613}$ Кто бы мог подумать, что это случится?? Я не еду в СССР по многим причинам. Одна из них (впрочем, не главная) что мои корреспонденты (их теперь 8) друг с другом не кланяются, и «гамма« их так широка, что я вряд ли смогу беспрепятственно с ними общаться.

Хотя мы с Вами редко сходимся во мнениях о современной франц. литературе, но я все-таки хочу Вам указать на писателя, кот. я только что для себя открыла: Жорж Мишель. ${ }^{614}$ Прочтите «Браво« и «Ле бан«. Я давно так не наслаждалась. Особенно хорошо французы сейчас пишут порнографию - из нее можно столько узнать о теперешней Франции! Нет претензий, нет скуки (которая меня душит), и я очень много читала за последнее время этот жанр литературы, в кот. французов превзойти никто не может. Кстати, дошла ли до вас книга «Московские ночи«? И как она Вам понравилась ${ }^{615}$

Если я не приеду в Париж в ноябре, то буду там в апреле. Соскучилась по городу. Думаю «смотаться« на две недели. Тем более, что финансовые мои дела после Курсива (как англ., так и русского) великолепны: я отказываюсь от «лекторских визитов«, кое-что редактирую, кое-где присутствую на экзаменах, вернее, защитах диссертаций.... Круг знакомых увеличился и отчасти изменился: вместо молодых, симпатичных

611 See note 271 to Berberova's letter of 1 September 1959.

612 Dmitrij Maksimov.

613 Lili (Lilja) Jur'evna Brik (1891-1978), Majakovskijs's muse.

614 Michel Georges-Michel (pseud. of Michel Georges Dreyfus, 1883-1985), writer, journalist, translator, artist.

615 Vlas Tenin's (= Petro Cveteremič) highly erotic Samizdat novel Moskovskie noči, New York 1971. 
и веселых друзей, появились знаменитые, пожилые и серьезные. Но сама я по-прежнему веселая. И очень много стала принимать у себя.

Привет.

Нина 
8 марта 1974

Дорогой Гуля, откуда Вы взяли, что я у Вас прошу адрес Ляли Зейлигер? Я никогда его у Вас не просила, никогда не собиралась ей писать. Зачем Вы беспокоили ее? Разве Вы не знаете, что т а м люди вовсе не ищут переписки с западными людьми? Я право в полном недоумении: Вы просто или не читаете моих писем, или их не понимаете. Это уже не первый раз, что Вы вычитываете из моих писем совсем не то, что в них имеется. Я просила Вас Ляле рассказать о том, что есть о ней и о ее семье в моем Курсиве. Ей это будет приятно. Вот и все.

Я сейчас взялась за Дневник Гонкуров, впервые полностью опубликованный в 1956 году только! Это конечно не «литературный дневник«, как они думали, это интереснейшая этнография: полвека французского быта. Я Вам очень советую за него приняться. Получите удовольствие огромное, и увидите, откуда вышел так называемый «реализм« - из диссекции в анатомическом театре, борделя и уборной. Всего - 5 тысяч страниц, и конечно, это очень длинно, но тем не менее, очень интересно. ${ }^{616}$

«Курсив« понемногу, очень медленно, начинает доходить до Сов. Союза. И всё чаще и больше обо мне - в сов. печати. Недавно вышел Архив Бунина (Литер. Наследство 84) - два тома. ${ }^{617}$ Там напечатаны «очень ценные«, как они выражаются, письма Бунина ко мне. Получаю письма от читателей «Курсива«, а недавно даже получила чудный из Москвы подарок от одного литературоведа.

Но ехать, как Вы советуете, я пока не еду. На это у меня есть свои причины и соображения. Да меня и не зовут.

Пожалуйста, в будущем, внимательно читайте, что я Вам пишу. И не ставьте себя и меня в трудное положение. С советскими друзьями надо быть осторожным, и я удивляюсь, что Вы этого не знаете до сих пор.

Привет.

Нина

616 See note 599 to Berberova's undated letter 1973.

617 Literaturnoe Nasledstvo: Ivan Bunin 1-2, Moskva 1973. 
Принстон, 2 мая 1974

Милый Гуля, недоразумения в нашей переписке не только огорчают меня, но и беспокоят: Вы забываете, о чем и как писали мне, обижаетесь на меня зря, и не понимаете того, что я Вам пишу. В письме, кот. я получила от Вас вчера, Вы написали: «Ваше письмо меня огорчило, я этого не заслужил. Ч Что это значит? Я никакого письма Вам не писала. Мое последнее письмо было от начала марта, и Вы на него спокойно ответили мне 14-го марта. Больше писем я Вам не посылала, и на что Вы обиделись - непонятно.

Затем: мои слова, что я «не думала писать Ляле 3. «618 Вы восприняли как некую грубость, когда это просто ф а к т.

Я никогда не думала требовать от Вас, чтобы Вы заучивали мои страницы наизусть и потом их декламировали в Ленинграде. Почему Вы мне приписываете такие глупые намерения? Единственный, простейший и весьма дешевый способ (3 сента страница, у нас) сделать зерокс копии (страниц 4-5, вероятно) и повезти с собой, или послать Ляле. На таможне это будет выглядеть как детский рассказ. Вот и все.

А еще лучше - забудьте все это. Ничего не копируйте, ничего не запоминайте, и ничего обо мне не рассказывайте, а то кроме недоразумений между Вами и мной это ни к чему не ведет.

Кончила Гонкуров, и пошла в Шатобриана. После многих раздумий пришла к заключению, что у Франции было три мировых, громадных писателя: Шатобриан, Дидро и Пруст.

Посылаю Вам списки моих «публичных лекций« - которые читаю в разных городах США, в аспирантуре университетов. Думаю, что Вам будет любопытно видеть мои «достижения«.

Привет.

Нина

618 Elena (Ljalja) Zejliger. 


\section{Н. Н. БЕРБЕРОВА: СПИСОК ЛЕКЦИЙ НА РУССКОМ И АНГЛИЙСКОМ ЯЗЫКАХ.}

1. Символическая деталь в еe Function of the symbolic detail. функциональном развитии.

2. Толстой после «Анны Каре- Tolstoy after ANNA. ниной«.

3. Символизация Достоевского. Dostoevsky as symbolist.

4. «Петербург«. Предки романа ST. PETERSBURG. Its forefathers и «колесо« Белого. and Bely's "wheel".

5. Структуры Ремизова. Remizov's structures.

6. Набоков и его «Лолита«. $\quad$ Nabokov and his LOLITA.

7. Механизм «Бледного огня«. The Mechanics of PALE FIRE.

8. Поэтические приемы в прозе Poetic devices in Nabokov's Prose Набокова («Дар«). (THE GIFT).

9. 50 лет советской литературы. Fifty years of Soviet Literature. (1917-1967).

10. Оттепель в советской кри- The "thaw" in Soviet Lit. Criticism. тике.

11. Техника поэтического пере- The techniques of Poetry translation. вода.

12. Два сказа - реалистический Two modes of narration. и символический.

13. Марина Цветаева. «Час Explication de Texte. A poem by душик. Tsvetaeva.

14. Структурализм в поэтике. Structuralist Poetics. 
17 июня (1974)

Милый Гуля, пользуюсь Вашей добротой и посылаю Вам письмо Е. Ф. 3. (и фотографию). ${ }^{619}$ Волосы мои выцвели на солнце, я конечно нормально гораздо темнее. Чувствую себя хорошо, очки не меняю семь лет, волосы вьются, сбавила 14 фунтов (чем меньше есть - тем лучше, конечно). Так что нахожусь в полном порядке. Мечтаю закончить семестр в Колумбии и лететь в Сиаттл (там как раз живет мой ближайший друг, профессор в Филадельфии, с кот. я снята).

Письма Ваши (два) получила. Рада за Вас, что Вам хорошо и что ездите в Ленинград. Здесь у нас довольно много новоприбывших. Бывают у меня интересные люди. Не идут ни в какое сравнение с великими князьями, работавшими шоферами в Париже.

Я считаю Грасса и Бёлля великими писателями XX в. - ни в одной стране нет таких имен. «Портрет с Дамой« не могла выпустить из рук пока не дочитала: ново, умно, интересно, захватывающе построено и придумано. Но Грасс мне даже еще ближе.

Я открыла (для себя) Тракля. ${ }^{620}$ Что Вы думаете о нем? Максим дю Кам мне тоже показался очень интересен. ${ }^{621}$

То, что Вы пишете о Париже, конечно ОЧЕНЬ грустно. Но у меня все растет ностальгия (в связи с переменой режима) и я чувствую, что в один прекрасный день я, не долго думая, полечу... Впрочем, не сейчас! Будьте здоровы.

Нина

619 Elena Zejliger.

620 Georg Trakl (1887-1914), Austrian poet, whose works are dominated by an atmosphere of pain and sorrow. Died early in WWI from an overdose of cocaine.

621 Maxime Du Camp (1822-1894), French writer. Traveler, especially in the Orient. 
Принстон, 20 июня 1974

Дорогой Гуля, я Вам годами пишу о том, что Вы никогда ничего мне не пишете о себе - здоровье, настроения, друзья, времяпрепровождение - все это мне всегда интересно. А Вы мне на это пишете о своей «питерской приятельнице«, которая Вас упрекает в том, что Вы только интересуетесь собой! Ей бы жить во времена королевы Виктории, когда люди говорили т о л ь к о о погоде, прислуге и родственниках! Тем не менее Ваши письма в с е г д а интересны. И я рада, что (так по крайней мере можно заключить) Вам живется без мучительных забот, тревоги, скуки и т.д. - всех ядов современного человечества. И без болезней? Кстати, сообщите мне, какое у Вас давление крови, как работает сердце?

Знаете ли Вы, что теперь лететь через океан стоит почти в д в о е против прежнего? Я прямо ушам своим не поверила. Между тем, у меня ностальгия по Парижу. Да, по Парижу, именно по нему. Есть еще 2-3, а может быть и 4 человека, с которыми хочется повидаться (особенно - с одним другом моим, который теперь живет там), но главное - соскучилась по городу, языку.... Должна навести справки, когда дешевле всего можно было бы приехать на 2-3 недели. М.б. в ноябре? У меня, как я Вам не раз писала, финансы в порядке, но все-таки надо быть осторожной. А хочется ужасно. Особенно после новой политической конъюнктуры. ${ }^{622}$

Лето у нас на редкость прохладное - по европейскому счету 25-28 градусов. В прошлом году по три недели температура не спускалась ниже 25-ти. Это для меня очень важно, потому что два раза в неделю я езжу в Нью-Йорк (от 9-ти до 9-ти), читаю лекции и веду семинар в Колумбийском университете. Студенты хорошие, хотя хуже, чем год назад. Боюсь, что изучение «русской литературы« приходит к концу, потому что сама эта литература пришла к концу.

От Синявского получила несколько интересных писем, восторженных о моем Курсиве. Так же и несколько писем из Сов. Союза. Читаю книги по экономике (!).

Привет.

Нина

622 President Richard Nixon was forced to resign in 1974 due to the Watergate scandal. He was replaced by Gerald Ford. A new presidential election was approaching in the fall. 
А что Вы думаете о политическом кредо Солженицына? ${ }^{623}$ Напоминает секту Эмиш (менониты), кот. интересовался Лев Толстой. ${ }^{624}$ Читали ли ответ ему Сахарова? 25 Этот ответ был большим утешением всем здесь.

623 Aleksandr Solženicyn, Pis'mo voždjam Sovetskogo Sojuza, Paris 1974.

624 Old Order Amish Mennonite Church, an ethnoreligious movement in the United States with roots in Swiss Anabaptism.

625 Andrej Sacharov, “O pis'me A. Solženicyna voždjam Sovetskogo Sojuza,” Kontinent 2 (1975). 
Милый Гуля,

вернулась из Сиаттла месяц назад и не нашла времени Вам ответить на два Ваших письма! Жизнь меня закрутила. Теперь все мои друзья (6-7) живут вокруг меня (от Нью-Хейвена до Филадельфии) и это огромное для меня счастье. Книга мне принесла (русское издание) столько новых встреч, новых друзей, новых радостей, что я и сказать не могу. Познакомилась в Сиаттле (читала там лекцию и записывала на пленку поэзию от Державина до Пастернака) с людьми приехавшими из Ленинграда после 10 месяцев жизни там. Они видели многих из моих корреспондентов. Переписка с Парижем тоже очень захватывает меня (Синявский и др.). Что Вы думаете о Солженицыне и его «нео-славянофильстве«? Я здесь встречаю и балетных москвичей, выпущенных наконец в западный мир, и мировых ученых из Москвы, кот. Дорогая Родина начала выпускать в массовом масштабе.

Недавно была в «Русском Семинаре« в Колумбии: раз в месяц съезжаются самые видные американские литературоведы и обсуждают интересные вопросы. Два моих друга переводят заново «Петербург «. ${ }^{626}$ Очень важны, как Вы понимаете, стишки в нем помещенные (смесь «Что танцуешь Катенька«, Смердякова и Лебядкина ${ }^{627}$ ), и я была чем-то вроде со-докладчика. Потом на три дня уехала в Нью-Хейвен (Йель), где остановилась у Ренэ Веллека (автор переведенной на 28 языков «Теории литературы«, без кот. шагу ступить нельзя). ${ }^{628}$ От вечеринки к вечеринке - всё старые друзья. Очень было приятно опять всех увидеть.

Мои два (лучших) аспиранта делают блестящие карьеры: один в Колумбии, другая в Йеле. Понемногу начинаю работать над комментариями к переводу на английский «Первого свидания (будет около ста страниц к 60-ти стр. текста). ${ }^{629}$ Вообще, нет дня, чтобы чего-нибудь интересного не стряслось со мной. Кажется, никогда так не жила. А главное - новые люди, и всё молодые, появляются кругом. И есть среди них чудные, умные, и преданные мне люди.

626 Robert Maguire and John Malmstad's new and extensively annotated translation of Peterburg, Bloomington and London 1978.

627 The would-be poet Captain Lebjadkin in Dostoevskij's Besy.

628 Czech-born and London-schooled René Wellek's (1903-1995) classic Theory of Literature (co-authored with Austin Warren) was originally published in 1948.

629 This resulted in Andrey Bely, The First Encounter, "Translated and Introduced by Gerald Janeček. Preliminary Remarks, Notes and Comments by Nina Berberova," Princeton 1979. 
Надеюсь, Вы здоровы и благополучны. Знаете ли Вы америк. писателя Гор Видаль? Это псевдоним - пишется ГОРЕ ВИДАЛ - он выбрал его нарочно. Я его люблю, и ессэ у него интересные. ${ }^{630}$ Но конечно ему далеко до Грасса. Привет.

Нина

630 Gore (Eugene Louis) Vidal's (1925-2012) "Russian pseudonym” was a combination of his mother's and father's surnames. 
Принстон, 4 февраля 1975

Милый Гуля, Вы меня разволновали Вашим письмом: Таня подружилась с Козинцевой??? Какой??? Люба Эренбург, жена И.Г.Э., ${ }^{631}$ называлась всегда Люба Козинцева, но Костакис ${ }^{632}$ мне сказал два года тому назад, что она умерла (кстати, в Москву стоит съездить ради его галереи). Люба была сестрой недавно тоже умершего режиссера Григория Козинцева. ${ }^{633}$ М. б. Таня познакомилась с его вдовой?? Умоляю, написать как можно скорее, что все это значит. И кстати, м. б. Вы знаете, куда девалась коллекция Эренбурга (картин).

В одном письме Гиббон ${ }^{634}$ в старости писал: Я возмутительно счастлив и бессовестно энергичен. Вот так и я. Если мы встретимся в Париже весной (что будет чудно, конечно, если Вы обещаете мне не говорить о Вашей любви к Ратгаузу и Мастеру и Маргарите), то Вы увидите, как я изменилась. Физически, т. е. внешне, тоже, но это не важно, и я люблю свои морщины, и совершенно не страдаю от них. Но «внутренне« я стала совершенно другой: перманентно счастливой. Это я Вас предупреждаю, чтобы Вы не слишком удивились.

Я недавно прочла Уве Йонсона «Zwei Ansichten« и причислила его к лику моих любимцев - Грасса и Бёлля. ${ }^{635}$ Знаете ли Вы его? Он конечно многому научился у Робб-Грийе, но гораздо лучше него. ${ }^{636}$ Прочтите, если не читали.

Предвкушаю Ваши долгие рассказы о Ленинграде (о «славных« и «интересных« людях). Нет у Вас соблазна остаться там? Почему? Ведь наверное таких людей мало в Стокгольме? А люди - это конечно $\mathrm{BCË.} \mathrm{Не} \mathrm{пейзажами} \mathrm{же} \mathrm{любоваться} \mathrm{в} \mathrm{наши} \mathrm{годы!}$

Анекдот про божественный звук эллинской речи я слышала уже в 1950 году в Париже. А насчет е.б.ж. я с Вами несогласна: меня всегда, с ранних лет, беспокоил этот звук, и я никогда не рисковала цитировать эти буквы - разве только иронически, для тех, кто понимал, как я, что

631 Ljubov' Kozinceva-Ėrenburg (1900-1970), painter, graphic artist, Il'ja Ėrenburg's wife.

632 George Costakis (1913-1990), Russian-born Greek collector of modern art, emigrated from the Soviet Union in 1977.

633 Grigorij Kozincev (1905-1973).

634 Edward Gibbon (1737-1794), British historian, author of The History of the Decline and Fall of the Roman Empire.

635 Uwe Johnson, Zwei Ansichten, Frankfurt am Main 1965.

636 Alain Robbe-Grillet (1922-2008), writer and cinema director, creator of the "New Novel." 
их вслух произносить не надо. ${ }^{637}$ Это так же смешно, как выражение о каком-нибудь гнусном поступке «ниже ватер-линии«. После второго слова лучше не останавливаться. Привет.

Нина

637 When speaking of future plans in his diaries, Tolstoj repeatedly inserted the reservation “e. b. ž." (= esli budem živy). 
Принстон, 7 апреля 1975

Дорогой Гуля,

спасибо за письмо. Брюсов не исправлял Пушкина (Как уст румяных...), а иронизировал. ${ }^{638}$ Как Вы могли не понять иронии? Впрочем, это пустяки. Я сняла в Париже небольшую «студию« на рю Микельанж. Я буду там во второй половине мая и в начале июня. Между 5 и 10 июня я уеду в Женеву - Женевский университет пригласил меня читать там 2 лекции и может быть - вечер стихов (не моих). Я теперь всюду позволяю делать пластинки моего чтения - голос пока еще звучит отлично. И почти все места, куда я ездила за последние годы, имеют ленты.

Напишите мне, будете ли Вы в Париже в мае, или в июне? Главная моя цель - восстановить язык, который я порядком потеряла. Буду ходить каждый день либо в театр, либо в кино, читать три газеты в день и разговаривать с кем только смогу. Героические планы!

Вернулась только что из Кентукки, где был симпозиум об А. Белом, которого я пропагандировала здесь 15 лет и вот - дожила до результатов. ${ }^{639}$ Было 22 доклада, из них 15 очень высокого уровня. Видела там Г. Струве - но он, конечно, докладов не читал, он сам знает, что не специалист этого дела. Выступала и я, и несколько блестящих моих студентов, а теперь профессоров. Среди них - молодая - Кэрол Аншютц, которую по моей рекомендации недавно пригласили в Йельский университет. Она писала со мной диссертацию о Котике Летаеве. ${ }^{640}$

Я сейчас читаю Лэото. У него есть Дневник (19 томов) страшно интересный. Читаю я выпущенный в 1969 г. «избранный том« (900 страниц). Это чтение для Вас: все знакомые, много любимцев. Эпоха - 1893-1956. Он писал тоже под псевдонимом М. Броссар, и работал в Меркюр де

638 Valerij Brjusov had commented sarcastically on Puškin's good-humored acceptance of grammatical lapses in lines from the third chapter of Evgenij Onegin: "Kak iz rumjanych ust bez ulybki/ bez grammatičeskoj ošibki/ ja russkoj reči ne ljublju."

639 "The Andrey Bely International Symposium 27-29 March 1975." Berberova could have had grounds to claim that she pleaded for Belyj for almost 25 years. In 1951 she published "A Note on Andrey Biely" in The Russian Review 2, where she stated that Peterburg could have influenced world literature if only it had become known at an early stage. Here with reference to Peterburg she spoke about the symbolic significance of "the ring" to Belyj.

640 In 1972 at Princeton, Berberova's student Carol Anschuetz had defended her Ph.D. dissertation Word Creation in Kotik Letaev and Kreščenyj kitaec. 
Франс в течение 40 с лишним лет. Кого тут только нет!... Сам он, как говорится, мало «симпатичный«, но умен и прямолинеен. ${ }^{641}$ Привет.

Нина

641 Paul Léautaud (1872-1956), French writer whose diaries in 19 volumes had become a classic in the genre. 
Принстон, 5 мая 1975

Милый Гуля,

получила Ваше письмо. Очень жалею, что Вы, оттого что в Париже Вы не можете больше «фланировать«, не приедете туда, когда я там буду. Я сняла квартиру, буду уютно жить и собираюсь восстановить французский язык, который из меня улетучивается. В Женеве нам увидеться не удастся: я там буду три дня и приеду для трех лекций в первой половине июня. Будет не до «фланирования« по Женеве, буду трудиться в поте лица.

Много дел сейчас перед отъездом, потому пишу кратко. Надо ответить на письма, собраться с мыслями, съездить в два или три места - проститься с друзьями.

Вы совершенно правы: Брюсов описался, когда написал о женских письмах.

Струве не делал доклада о Белом. Он как-бы открыл симпозиум, более или менее перечислил все произведения, кое-какие критические высказывания о Белом и т.д. Он, видимо, готовился к студенческой аудитории, и сделал некий информационный обзор. Но в зале сидели только те, кто делали потом доклады и те, что зубы съели на Белом, которого - как Струве сам мне потом сказал - он и не знает, и не принимает, и не любит. ${ }^{642}$

Всего хорошего. Привет.

Нина

642 See note 639 to Berberova's letter of 7 April 1975. 
Принстон, 9 августа 1975

Милый Гуля, спасибо за письмо. Посылаю Вам поправки к «мемуарам« Бахраха, кот. Вы так хвалили и кот. так жаждала прочесть. Пошлый тон и, к сожалению, ослабевшая память!

Я занята подготовкой курсов к январю. Литература постепенно вся переходит в компаративизм, и «Историю русск. литер. критики«, кот. я буду читать, я совершенно переделываю: о Белинском - чем меньше, тем лучше, а гл. обр. - структурализм. Сейчас читаю де Соссюра ${ }^{643}$ и увлекаюсь им.

«Радецкий марш« мне совершенно неизвестен, как и его автор. ${ }^{644}$ Переписку Чичерина и Кузмина я читала, как и многое другое, что 8 лет назад привез в рукописях мой студент, а теперь профессор. ${ }^{645}$ Среди них - записи Любовь Дм. о ее жизни с Блоком ${ }^{646}$ письма Цветаевой к Пастернаку (кот. до сих пор считаются утерянными) и мн. другое. ${ }^{647}$

Живется мне хорошо, весело и интересно. Париж оставил во мне скорее мрачное впечатление. Пишу стихи.

Привет.

Нина

643 Berberova's interest in structuralism had evidently led her to read the father of structuralist theories, Ferdinand de Saussure (1857-1913).

644 Joseph Roth (1894-1939), author of Radetzkymarsch (1932).

645 John Malmstad. See note 422 to Berberova's letter of 16 February 1967.

646 See note 606 to Berberova's letter of 15 January 1973.

647 Marina Cvetaeva's letters to Boris Pasternak (which were lost during the war) have to some extent been reconstructed on the basis of drafts and copies. 
Стр. 295 - Не «Золото и лазури«, а «Золото в лазури«. ${ }^{648}$

296 - Не Негорелое, а Себеж в то время был пограничным пунктом.

298 - «Стареющей женщине« (А. Тургеневой) было в то время немного более 20-ти лет. Кусикову было 26-27 лет. ${ }^{649}$

301 - В «Беседе« не было статьи Белого, где в названии было бы слово «прагердильствовать«.

303 - В Берлине не было «гумов«. ГУМ - гос. универ. маг. В Германии не было государственных магазинов.

306 - Гейсбергштрассе, где жило много русских эмигрантов в пансионе, выходившем окнами на Нюренбергер плац, где помещалось (в том же доме, где был пансион) кафе Нюренбергер плац, почти столь же популярное, как и Прагер Дилэ, ближе к Лютерштрассе, чем к концу Курфюрстендамма. Непонятно, как, идя с Лютерштрассе «домой«, пройдя весь Курфюрстендамм, «изрядное количество километров«, Белый и автор оказались на Гейсбергштрассе, где оба часто бывали у нас (мы жили там с июня по август 1922 г.).

307 - Как автор мог не знать о «переселении душ«, т.е. о различных воплощениях - это основа учения Штейнера. ${ }^{650}$

310 - Белый «заглядывал в Прагердиле« не после того, как писал о ней, а раньше, до писания о берлинской жизни.

314 - Фотография (групповая), воспроизведенная в моем «Курсиве«, была сделана осенью 1923 г. После нее не могло «близиться лето«.

316 - Предположение, что «черный сундук« оказался в конце концов в руках Ходасевича, а потом (видимо через мои руки) некоторые бумаги попали «в один из американских университетов« - к сожалению выдумка. Я точно сказала, куда и как ушли архивы Белого из Берлина после его отъезда: см. «Курсив мой« стр. 466.

648 Andrej Belyj's first collection of poems (Moscow 1904).

649 The Imaginist poet Aleksandr Kusikov (1896-1977), with whom Asja (Anna) Turgeneva (1890-1966, Belyj's first wife) had a liaison in the early 1920s.

650 Rudolf Steiner's Anthroposophy. 